\title{
THE DINOFLAGELLATES OF NORTHERN SEAS
}

BY

MARIE V. LEBOUR, D.Sc., F.Z.S.

NATURALIST AT THE LABORATORY OF THE MARINE BIOI.OGICAL ASSOCIATION OF THE UNITED

KINGDOM, PLYMOUTH

PLYMOUTH :

PUBLISHED BY THE MARINE BIOLOGICAL ASSOCIATION OF THE UNITED KINGDOM:

COPIES MAY BE OBTAINED FROM THE DIREOTOR, MARINE BIOLOGICAL

LABORATORY, CITADEL HILL, PLYMOUTH.

AGENTS IN LONDON : MEssRs. DULAU \& CO., LTD., 34-36 MARGARET STREET, CAVENDISH SQUARE, W. 1.

Price $12 / 6$ nett. (Post free, 13/-).

LIBRARY,

M.B.A.

PLYMOUTH. 


\section{CONTENTS}

Author's Preface vii

Introduction . . . . . . . . . 1

General Morphology . . . . . . . . . 24

Nutrition . . . . . . . . . . . 4 4-6

Reproduction . . . . . . . . . . . .

Habits, etc. . . . . . . . . . . . $6-9$

Classification . . . . . . . . 10-11

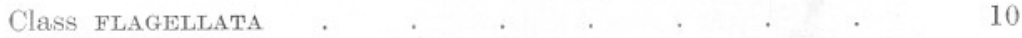

Family Prorocentridae . . . . . . $12-17$

Genus Exuviella . . . . . . . 13-15

Prorocentrum . . . . . . $15-16$

Family Pronoctilucidae . . . . . . . $17-19$

Genus Pronoctiluca . . . . . . . 18

Oxyrrhis . . . . . . $18-19$

Family Gymnodiniidae . . . . . . . $20-66$

Genus Hemidinium . . . . . . 20

Amphidinium . . . . . 21-34

Gymnodinium . . . . . $\quad . \quad 34-50$

Gyrodinium . . . . . . $\quad .51-61$

Cochlodinium . . . . . 61-65

Torodinium . . . . . $\quad$. $\quad 65-66$

Family Polykrikidae . . . . . . $67-68$

Genus Polykrikos _. . . . . . $\quad 67-68$

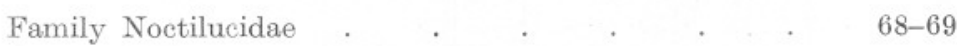

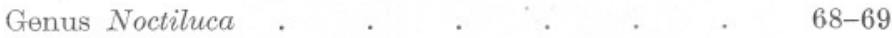

Family Pouchetiidae . . . . . . . $\quad$. $69-73$

Genus Protopsis . . . . . . . 69-71

Nematodinium . . . . . . . . . 71

Pouchetia . . . . . . . . 71-73

Protoerythropsis . . . . . . . $\quad 73$ 


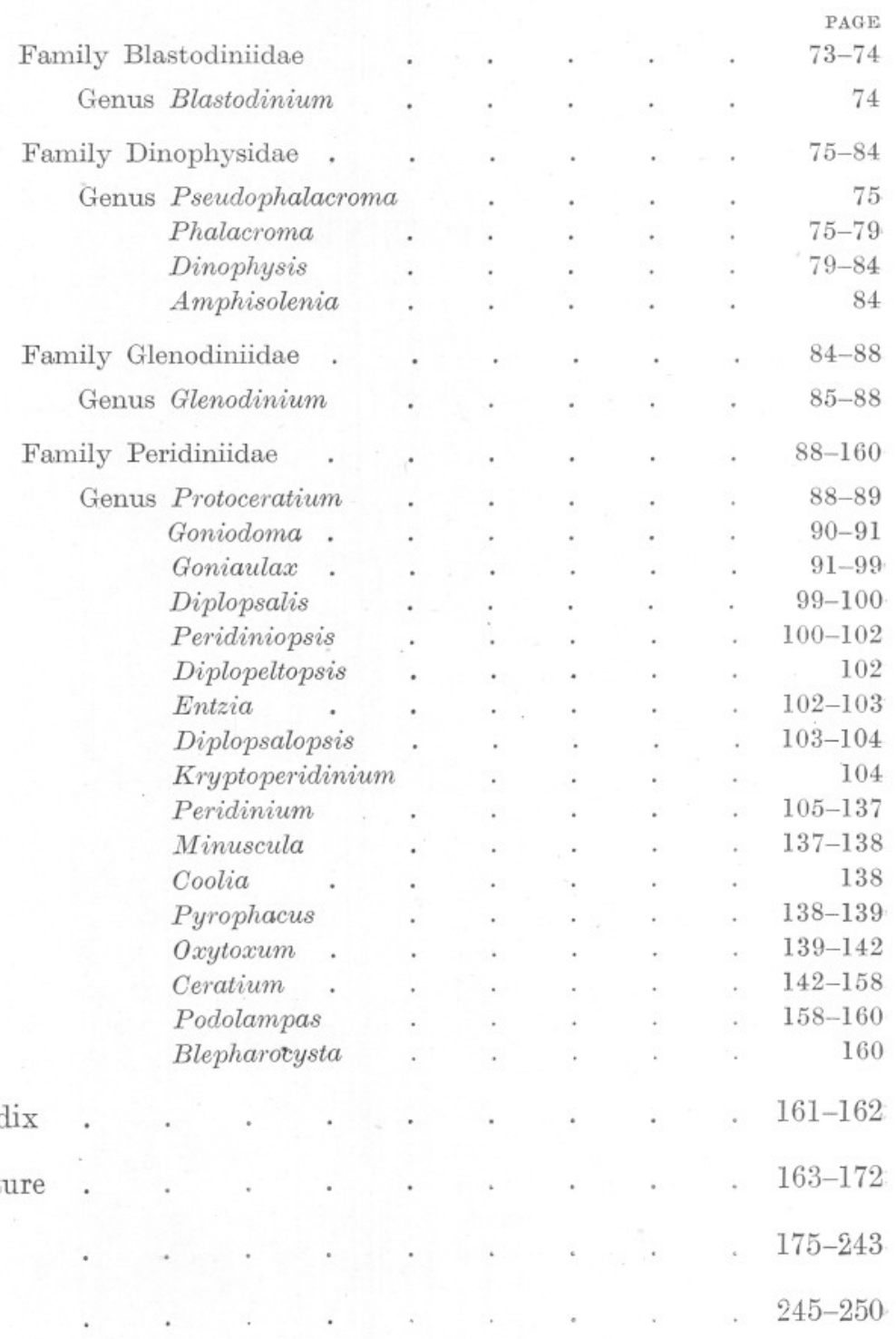




\section{PREFACE}

The author is indebted to the Royal Society and to the Development Commissioners for grants which have enabled this book to be published. Her best thanks are due to Dr. E. J. Allen, F.R.S., Director of the Plymouth Laboratory, and all the Members of the Staff for their unfailing interest and help, especially to Mr. F. S. Russell, who has seen the work through the press, and also to all those outside workers who by their readiness in sending specimens and literature and allowing their individual observations to be used have facilitated in no small degree the task of putting together a large mass of facts. Lastly, she wishes to acknowledge the help of all those authors quoted whose works and figures have been so freely used throughout the book. 


\section{INTRODUCTION}

Much has been added to our knowledge of the dinoflagellates or peridinians since the publication of that part of "Nordisches Plankton" (Paulsen, 1908) which deals with these organisms; it is therefore the aim of this work to make as complete a survey as possible of all the marine members of the group which are known to occur in the Northern Seas up to the present time. The area covered is not strictly defined, but is mainly that of the International Investigations for the Exploration of the Sea. More northerly forms are, however, included, such as those from the East Greenland Sea and the Barents Sea ; the southerly records stop at the north-west coast of France and do not include the Mediterranean. Westerly records go as far as Iceland and the Eastern Atlantic, and easterly records as far as Finland and the White Sea.

A short description is given of each species and, when possible, a figure drawn from nature: when these drawings could not be obtained, figures copied from those of other workers are used. All the illustrations, except when otherwise stated, are by the author. These original figures are drawn as nearly as possible to scale and occupy the plates. Other figures taken from different authors are placed in the text and are of various magnifications.

For the sake of brevity all literature referring to synonymy included in "Nordisches Plankton" is omitted and reference given to that work under every species mentioned in it. Similarly for the naked forms reference is made to the monograph by Kofoid and Swezy (1921).

It is hoped that this survey may be useful to the beginner as well as to the trained worker. For this reason a brief summary of the group is given, and, as far as possible, every technical term is explained the first time it is used.

The author is indebted for general information to many well-known works from which much has been taken, especially Paulsen's " Nordisches Plankton," West's "Algae," Schütt's "Peridiniales of the Plankton Expedition," and Kofoid and Swezy "A Monograph on the Unarmoured Dinoflagellates " and many works by Jörgensen, Kofoid, Paulsen, Ostenfeld, Gran, Pavillard, Mangin and others, reference to which is given below. 


\section{THE DINOFLAGELLATA}

\section{General Morphology}

The dinoflagellates form a large group occurring in the sea, in brackish and in fresh water. It is only those from the sea and in certain cases from brackish water that concern us in the present work. All are microscopic, the largest appearing to the naked eye as a minute globule, the smallest only being apparent with the high power of a microscope. In size they range from $7 \mu$ ( $\mu=$ a micron, or $\frac{1}{1000}$ of a millimetre) to $2 \mathrm{~mm}$., which is the size only occasionally reached by Noctiluca, the largest known dinoflagellate.

Each individual is composed of a single cell provided with two whiplike hairs or flagella, one more or less longitudinal, the other more or less transverse. The nucleus has a definite specialised structure, its chromatin being distributed in the form of bead-like strands. The cell may be naked and only bounded by the thinnest pellicle, or it may have an outer covering of cellulose or some closely related substance, the theca. The naked forms at certain times may be enclosed in a thin-walled, usually structureless, case, and similar cases may enclose the armoured or thecate forms (i.e. those with an outer covering).

The group is divided into two orders. One is entirely without a transverse groove, and here the two flagella are probably anterior : this order is known as the Adiniferidea. The majority of forms, however, are included in the second order, the Diniferidea.

The Adiniferidea may be naked or may have a covering or theca composed of two plates. The Diniferidea may be naked or provided with a theca of more than two plates. These latter are the typical dinoflagellates. In shape they may be more or less heart-shaped, pear-shaped, spherical, oval, bi-conical, spindle-shaped or lens-shaped, but by means of flattening of the cells and spine-like projections or membranes all sorts of grotesque shapes may be produced which are in many cases adapted for flotation.

The cell (Text-figure 1, p. 3) is divided by the transverse groove, the girdle (g.) or transverse furrow which lodges the transverse flagellum (t.f.) into an anterior and a posterior portion, the epicone (e.) and the hypocone (h.). The tip of the epicone is the apex, and that of the hypocone the antapex. A longitudinal groove or furrow for the lodgment of the longitudinal flagellum (l.f.) lies ventrally, dividing the cell into right and left halves ; this groove is known as the sulcus (s.). The flagella emerge from two ventral pores, one anterior for the transverse flagellum (a.f.p.), the other 
behind it for the longitudinal flagellum (p.f.p.). These may be close together or far apart, or they may be fused. The transverse flagellum is a strong thread, usually provided with a thin membrane, which is lodged in the girdle groove and runs from the left side dorsally and vibrates continually. The longitudinal flagellum is lodged in the sulcus and usually projects behind, having a whip-like motion, or it may trail. By means of the combined activities of the two flagella the typical spiral forward movement is produced, which is primarily due to the asymmetry of the cell, for the cell is nearly always asymmetrical, either slightly or to a large extent, and this is typical of the group. The girdle may be

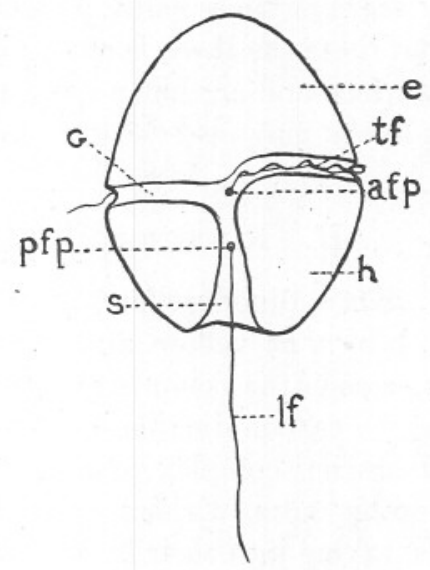

FIG. 1. Diagram of typical naked dinoflagellate.
e. =epicone.
$h .=$ hypocone.
$g .=$ girdle.
$s .=$ sulcus.
t.f. = transverse flagellum.
$l . f .=$ longitudinal flagellum.
a.f.p. = anterior flagellar pore.
$p . f \cdot p .=$ posterior flagellar pore.

completely equatorial with its ends meeting ventrally, or it may be displaced so that one end lies below the other. If the right end is below the left, the girdle is said to be a descending spiral (or left-handed); if above the left, it is said to be an ascending spiral (or right-handed). All the naked forms so far known have the girdle, if displaced, a descending spiral, and so do most of the thecate forms; such a condition being presumably primitive. The section Metaperidinium of the genus Peridinium has the girdle an ascending spiral.

The thecate forms may have a covering composed of three parts : epitheca (covering the epicone), girdle plate (covering the girdle) and hypotheca (covering the hypocone); or these may be severally divided up into many plates, those of the epi- and hypotheca being arranged in 
a variety of patterns. By the number and arrangement of these plates the thecate forms are classified. The girdle plate usually has projecting edges and is often provided with thin membranes, one on each edge, the transverse lists. The sulcus may also be provided with lists. Either or both transverse and longitudinal lists may be strengthened by spines. Between the plates there are often widely striated areas known as the intercalary areas or intercalary striae. These are really the edges of the plates themselves and are regarded by some authorities as areas of growth, thus allowing enlargement of the theca. The theca is usually sculptured with a pattern consisting of small depressions known as poroids; when these are surrounded by thickened margins so that a network is formed they are sometimes called areoles, or the theca is said to be reticulated. Besides these the theca is often pierced by pores which are scattered over the surface and are not necessarily in connexion with the poroids. Spines or knobs may also decorate the theca.

\section{NUTRITION}

The food is varied. Some dinoflagellates contain colour bodies or chromatophores, green, brown or yellow, and these, like typical plants feed holophytically, by means of the colouring matter (chlorophyll, or an allied substance), fixing the carbon dioxide in the water in the presence of sunlight and manufacturing complex organic food substances from this together with inorganic salts. Others feed holozoically, that is to say like typical animals, taking into their bodies other organisms, which have already manufactured the essential elementary food materials, digesting these, and getting rid of any portion not used. Among the organisms thus eaten are diatoms, flagellates and other dinoflagellates, besides, in certain cases, some of the smaller metazoa or many-celled animals. Such holozoic forms are most of the naked dinoflagellates, some of which have reached to a very high state of complexity, even possessing beautifully formed stinging cells or nematocysts and well-developed eyes with lenses. Others have long tentacles and amoeboid processes presumably for catching food. The area for ingesting the food is almost certainly the sulcus, which is often very mobile and greatly extensible. Many organisms have been seen inside these naked forms, especially in Noctiluca, any one cell of which may contain a large collection of small prey. Larval copepods have been seen inside Noctiluca by the author. Both naked and thecate forms may contain chromatophores and live holophytically, but only the non-thecate forms are known to live holozoically.

The thecate forms without chromatophores are numerous and may be colourless, pale yellow or pale pink. It is not certain how these feed, 
although most or all of them contain leucoplasts, which are small bodies related to chromatophores but colourless. It is probable that they are saprophytic, that is to say they live on decaying organic matter. All of them are provided with fluid reservoirs known as pusules, which open into the flagella pores and take fluid into the cell from outside. These pusules are not the same as contractile vacuoles, which discharge their contents to the outside and which are not present in dinoflagellates. Dangeard (1923) has recently shown in Ceratium and Peridinium, by
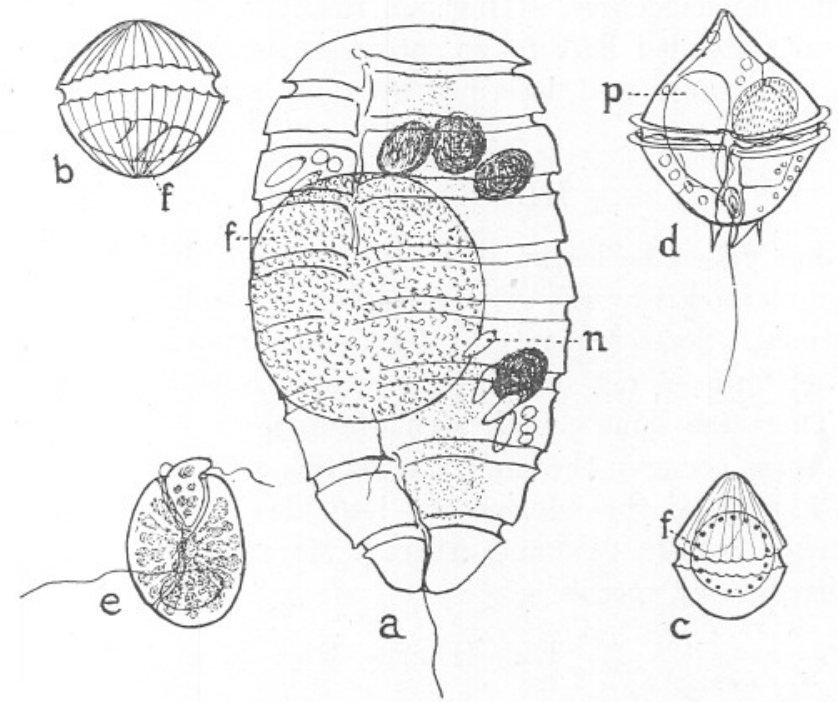

FIG. 2. The food of various dinoflagellates.

a. Polykrikos Schwarzii containing Peridiniopsis; $f=$ food, $n=$ nematocyst.

b. Gymnodinium sp. containing Cochlodinium, $f$.

c. Gymnodinium rhomboides containing a diatom, $f$.

d. Peridinium pellucidum, probably saprophytic, showing large pusule, $p$.

e. Typical holophytic form, Amphidinium Klebsii, with yellow chromatophores.

means of intra vitam stains, that marine Peridinians have a system of small vacuoles all over the body, distinct from the pusules, and which do not open to the exterior. These are similar to the vacuoles of certain plants and probably frequent in animal cells. They correspond to the normal vacuoles of Kofoid. It is possible that these thecate forms without chromatophores live on minute bacteria. Pusules also occur in the thecate forms with chromatophores and in many of the naked forms which are either holophytic or holozoic, but they are usually much smaller. (Text-figure 2.) 
There are also parasitic dinoflagellates which live on or in living organisms. Since the investigations of Chatton these are known to be very numerous. They may have an internal phase in the form of a large sac inside the body of some animal (often a copepod) in which a large number of small bodies multiply; these finally burst from the infested animal, or host, in the typical form of a naked dinoflagellate. The parasitic species are omitted in this work except for one representative species. For further reference to them see Chatton (1920) and Kofoid and Swezy (1921). The yellow cells of the Radiolaria are now known to be true Dinoflagellates. (Hovasse, 1923.)

It is not intended here to go into the complicated matter of food products, which are well described by many authors, especially Schütt (1895).

\section{Reproduction}

Much has yet to be learnt about the reproduction of dinoflagellates. The usual method is by cell division, either longitudinal or oblique, often asymmetrical. Some multiply by forming chains of individuals, others encyst and form spores, or spores may be formed within the ordinary theca. There are some complicated life histories known in which two or more forms occur in the same species (dimorphism or polymorphism). Mitotic division of the nucleus has been described in several species. [Entz (1921), Jollos (1910) and others.] More detail is given under the various genera and species.

\section{Haвits, Eтc.}

The simplest forms so far known occur in fresh water or brackish water. Haplodinium in fresh water leads up to those without a girdle; Pronoctiluca and Oxyrrhis in brackish water and in the sea, which with Hemidinium have incomplete girdles, lead up to the girdled species Amphidinium and Gymnodinium, typical naked dinoflagellates with complete girdle and sulcus.

In brackish water there are many holophytic species with yellow, brown or green chromatophores. These are principally thecate, although the simpler naked genera also occur. The species of Peridinium usually belong to the Orthoperidinium type (see under Peridinium), which is probably more primitive than Metaperidinium, and it is to be noted that all the true fresh-water species of this genus belong to Orthoperidinium. Goniaulax is often common in brackish water, as are Prorocentrum and Exuviella.

Large masses of one species may occur in estuaries, such as Kryptoperidinium foliaceum, which gives the water a greenish tint. There is only one common fresh-water species of Ceratium in this region, Ceratium 
hirundinella, which may also occur in brackish water: nearly all the species of this genus belong to the open sea.

A specially adapted group live on sandy beaches uncovered periodically by the tide. These are known as arenaciphilous or "sand loving." Miss C. Herdman, who has worked specially on these, has kindly shown me their haunts at Port Erin, Isle of Man. Another good locality for these forms is Cullercoats, Northumberland, and Mr. B. Storrow and Miss Jorgensen have investigated them here. Kofoid and Swezy have also described similar forms from California. All these are very much flattened either dorso-ventrally or laterally and are usually very mobile, and although some colourless forms are found, most of them are a deep yellow, being full of chromatophores. The most usual species belong to the genus Amphidinium, but Gymnodinium also occurs, and even Polykrikos, which in this case possesses chromatophores and no nematocysts and is flattened laterally. These species occur as brownish yellow patches on the beach between tidemarks, often covering a large area, and are subject to periods of appearance and disappearance. [Herdman (1911), C. Herdman (1921, '22, '23 and '24), Storrow (1913), Whitehead (1914), Jorgensen (1918).]

Near the coast in the sea are the neritic forms, or those that have their original habitat in coastal waters. These are very varied, consisting of the simpler naked forms, chiefly Gymnodinium and Gyrodinium, and many thecate forms, Prorocentrum, Exuviella, Protoceratium, Goniaulax, Diplopeltopsis, Peridiniopsis, Diplopsalis, many Peridinium, Phalacroma, Dinophysis, and an occasional Ceratium. At Plymouth the commonest neritic species are Peridinium Leonis, P. pellucidum, P. Faeröense, Prorocentrum micans, Gymnodinium rhomboides and Gyrodinium glaucum.

The neritic species are chiefly thecate; they may be holophytic with chromatophores, or colourless to pale pink or yellow and probably saprophytic. Most of them belong to the latter category, although there are many which have brownish yellow chromatophores, notably Goniaulax, Protoceratium and Peridinium Faeröense. On the whole the truly neritic forms are simple in shape without conspicuous wings or horns.

Oceanic species which have their origin in the open sea often mix much with the neritic forms, and it is sometimes difficult to distinguish those which are truly oceanic. The oceanic species include most of the naked forms, particularly those that have eyes or are brightly coloured, most of the species of Ceratium, many Peridinium species and a large number of the Dinophysidae, especially those which have conspicuous wings and spines and which are peculiarly shaped for adapting themselves to various depths of water and for keeping themselves afloat. The elongated and often thread-like Amphisolenia which are rare in the north, and Ornithocercus with enormously developed wings characteristic 
of warm seas, which are here entirely absent, are oceanic. Oxytoxum is also oceanic.

Peridiniopsis asymmetrica and Peridinium depressum are typical, commonly occurring open-water species. Most of the larger naked forms are oceanic, Amphidinium, Gymnodinium and Gyrodinium, reaching to a great size, and Cochlodinium, with its enormously twisted girdle, being abundant. Here occur the eyed species, Pouchetia, Nematodinium and others, culminating in Erythropsis with its prod, which apparently does not occur in the Northern regions. Many of the holozoic species are brightly coloured, but this does not apply so much to the Northern forms as to those in warmer seas. However, in our area there are some very brightly coloured forms, notably Gyrodinium britannia, known so far only from the waters round Plymouth. The oceanic species of Peridinium are chiefly destitute of chromatophores and are probably saprophytic. All the Ceratium species are holophytic and have yellow chromatophores. Most of the naked oceanic species are holozoic. On the whole the oceanic species are more highly organised than the neritic species are and frequently supplied with special adaptations for flotation and adjustment to various depths. In them are found the most wonderfully grotesque shapes with huge wings, horns and lists.

Dinoflagellates are lovers of warmth, although many are to be found in Arctic waters, but very few are to be found in winter in the area under investigation. With the coming of the longer days and more sunlight, usually about February, the diatoms begin to increase largely until a maximum is reached in the early spring. Directly after this maximum the dinoflagellates are to be found in quantities in the sea and are numerous throughout the summer, generally lessening in numbers in the early autumn until only a few stray specimens can be found.

The holophytic species must live in regions where the sunlight can penetrate, and most of them are found near the surface. This is apparently not so necessary for the colourless forms, although these are more often to be found near the surface also. However, many dinoflagellates of all kinds may be found at a depth of several metres.

Dinoflagellates come next to the diatoms in importance as food for the larger animals. They sometimes occur in enormous numbers and are the common cause of luminescence in the sea. Huge masses in tropical seas may colour the water, and are the cause of "red" or "yellow" water, which is usually due to a species of Goniaulax, although naked forms sometimes have the same effect. (Hirasaka, 1922.)

Some dinoflagellates are themselves parasitised by protozoa. These parasites are members of the Suctoria, of the genus Amoebophrya, which spend part of their life cycle in other unicellular organisms. Specimens of different species of Peridinium, Diplopsalis, Dinophysis and Gyro- 
dinium have been seen thus infested (Text-figure 3). For description of Amoebophrya, see Köppen (1894) and Borgert (1897).

The study of dinoflagellates is still in its infancy and we have yet to learn much about their life histories, methods of life and methods of feeding. In a work of this kind there is no room for discussion, but we shall probably find before many years have passed that a large proportion of those now regarded as species are merely phases in the life history
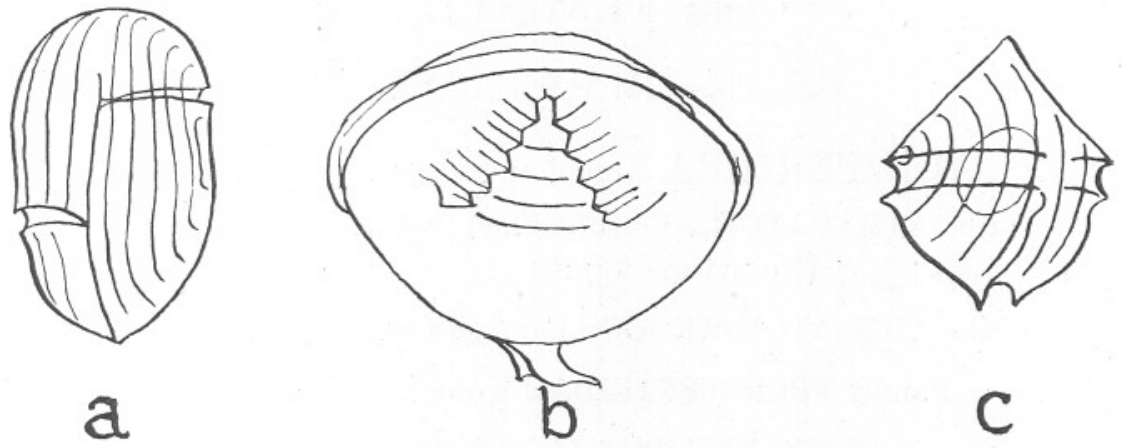

FIG. 3. Dinoflagellates presumably parasitised by Amoebophrya.
a. Gymnodinium sp.
b. Diplopsalis lenticula.
c. Peridinium sp.

of others. Especially does this apply to the small naked forms of Gymnodinium. Kofoid and Swezy (1921) believe that encystment and spore formation occur in all, and that the phases such as we get in Gymnodinium lunula are typical for the whole group. It is with the belief that the more our present knowledge is brought together the quicker shall we advance, that the present very inadequate survey is presented. In many instances in the following account of the naked forms the diagnoses of Kofoid and Swezy have been hardly altered, and acknowledgment is here made for all that has been used from that work. 


\section{CLASSIFICATION OF THE DINOFLAGELLATES}

The classification adopted here for the naked forms is chiefly that of Kofoid and Swezy (1921). For the thecate forms much help has been gained from the various works of Paulsen, Jörgensen and Kofoid, whilst part is new.

\section{Class FLAGELLATA \\ Sub-Class DINOFLAGELLATA}

Order ADINIFERIDEA Kofoid and Swezy.

Tribe ATHECATOIDAE Kofoid and Swezy.

(No marine forms.)

Tribe THECATOIDAE Kofoid and Swezy.

Family PROROCENTRIDAE Kofoid.

Genera Exuviella Cienkowski.

Prorocentrum Ehrenberg.

Order DINIFERIDEA Kofoid and Swezy.

Tribe GYMNODINIOIDAE Poche (emended by Kofoid and Swezy).

Family PRONOCTILUCIDAE nom. nov.

Genera Pronoctiluca Fabre-Domergue.

OxyrRHIs Dujardin.

Family GYMNODINIIDAE Kofoid.

Genera Hemidinium Stein.

AmpHidinium Claparède and Lachmann.

Grmnodinium Stein (emended by Kofoid and Swezy).

Gyrodinium Kofoid and Swezy.

Cochlodinium Schütt.

Torodinium Kofoid and Swezy.

Family POLYKRIKIDAE Kofoid and, Swezy (emended).

Genus Polykrikos Bütschli.

Family NOCTILUCIDAE Saville Kent.

Genus Noctiluca Suriray. 
Family POUCHETIDAE Kofoid and Swezy.

Genera Protopsis Kofoid and Swezy. Nematodinium Kofoid and Swezy. Pouchetia Schütt (emended by Kofoid and Swezy.) Protoerythropsis Kofoid and Swezy.

Family BLASTODINIIDAE Kofoid and Swezy.

(Parasitic forms.)

Typical Genus Blastodinium Chatton.

Tribe PERIDINIOIDAE Kofoid and Swezy.

Family DINOPHYSIDAE Kofoid and Michener.

Genera Pseudophalacroma Jörgensen.

Phalacroma Stein.

Dinophysis Ehrenberg.

Amphisolenia Stein.

Family GLENODINIIDAE n.fam.

Family PERIDINIIDAE Kofoid.

Genus Glenodinium (Ehrenberg) Stein.

Genera Protoceratium Bergh.

Goniodoma Stein.

Goniaulax Diesing.

Diplopsalis Bergh.

Peridiniopsis Lemmermann.

Diplopeltopsis Pavillard.

Entzia Lebour.

Diplopsalopsis Meunier.

Kryptoperidinium Lindemann.

Peridinium Ehrenberg.

Minuscula gen. nov.

Coolia Meunier.

Pyrophacus Stein.

Oxyтохuм Stein.

Ceratium Schrank.

Podolampas Stein.

Blepharocysta Ehrenberg. 


\section{Sub-Class DINOFLAGELLATA Bütschli}

Flagellata with two flagella; one longitudinal, thread-like, usually trailing, and posterior; the other usually ribbon-like and held transversely. Girdle and sulcus more or less well developed (except in the Adiniferidea). No contractile vacuole. Nucleus with bead-like chromatin strands. Body naked or covered with a theca. In the life cycle polymorphism may occur.

\section{Order ADINIFERIDEA Kofoid and Swezy.}

Without a girdle. Body either naked or with a theca of two parts. Nutrition probably entirely holophytic. Yellow chromatophores. No naked marine forms of this order are known.

Tribe ATHECATOIDAE Kofoid and Swezy.

Without a theca.

This is only represented by the fresh-water genus Haplodinium and not described here.

Tribe THECATOIDAE Kofoid and Swezy.

With a theca composed of two parts or valves.

\section{Family PROROCENTRIDAE Kofoid.}

Cell roundish, oval or heart-shaped, almost bilaterally symmetrical, flattened from side to side. Theca usually with poroids, sometimes with spines. There is some disagreement as to the orientation of these forms. The flagella end is here regarded as anterior and the valves right and left, following Klebs (1912). Bütschli (1885), Schütt (1896), and others however regard the valves as homologous with the epi- and hypotheca of the Peridiniidae, the seam representing the girdle. The theca as interpreted by Klebs is composed of two valves, right and left, joined by a simple seam. The flagella pass out by a slit in the front made by the hollowing out of the right valve, or may come from two pores (e.g. in Exuviella perforata). Near the exit of the flagella there may be teeth or processes. Progression is by means of the flagella which are anterior in position, the cell being dragged behind; the transverse flagellum usually vibrates more or less against the edge of the cell wall. Chromatophores, yellow or golden brown, plate-like, usually two, placed laterally, sometimes with a pyrenoid (a specialised round mass of reserve food) in the centre.

Multiplication by longitudinal cell division, each daughter cell having one old and one new valve. Megacytic forms, that is to say those with the edges of the valves enlarged for reproduction, may occur, in which there is a wide border to the valves with a different surface structure, making 
the cell much thicker. When division takes place this border overlaps the new valve and gradually disintegrates, having served its purpose in enlarging the cell.

The two genera recognised in this family are Exuviella and Prorocentrum.

\section{Genus Exuviella Cienkowski.}

Cell usually roundish or oval ; without or with only very inconspicuous spines near the exit of the flagella which emerge from a slit or from two pores at the anterior end. The species are truly marine, or may live in estuaries. A resting stage attached to weeds has been observed in one species.

Species :-Exuviella marina Cienkowski, E. compressa (Bailey), E. perforata Gran, E. apora Schiller, and E. baltica Lohmann.

Exuviella marina Cienkowski (1881).

Plate I, figures 1a-1d.

Exuviella lima (Ehrenberg) Bütschli.

Paulsen, 1908; Nordisches Plankton, p. 5.

Cell oval, broadest behind the eentre, much compressed laterally. Front end indented in both valves, without spines. Flagella emerge from a slit in front between the valves. Theca with fine scattered poroids. Two large yellow plate-like chromatophores with a pyrenoid in the centre of each. Nucleus posterior. Length $36-50 \mu$. May have a fixed resting stage attached to algae by a stalk. Division may take place in a thin cyst. Neritic near the coast or may live in sand between tidemarks. This latter habitat is probably its natural one as it occurs there in numbers far exceeding those caught at the surface of the sea. The sand-living forms are usually broader and less pointed anteriorly.

Widely distributed-in plankton from the White Sea, Brittany coast, North Sea, Irish Sea, English Channel; in sand from Port Erin, Isle of Man; the Lancashire coast and Cullercoats, Northumberland ; also Woods Hole, Massachusetts, U.S.A.

Klebs (1912) regards Exuviella lima Ehrenberg as a different species, having only one valve indented anteriorly.

Exuviella compressa (Bailey) Ostenfeld (1903).

Plate I, figure 2.

Paulsen, 1908; Nordisches Plankton, pp. 6, 7.

Cell oval, not much compressed. Each valve with a very small tooth near the exit of the flagella. Theca covered with conspicuous poroids.

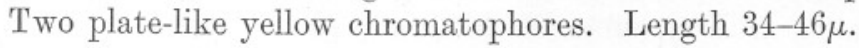


Atlantic, Mediterranean, English Channel (only one empty theca found at Plymouth).

\section{Exuviella perforata Gran (1915).}

Lebour, 1922, b.

Plate I, figures $3 a-3 c$.

Cell a round oval, flattened laterally. In the centre of each valve is a cone-like indentation facing inwards (Pl. I, fig. 3b). A row of poroids round the margin. One valve (the left ?) with two pores, presumably for the exit of the flagella, borne on a small projection which fits into an excavation in the corresponding valve (Pl. I, fig. 3c). Two yellow-brown irregular plate-like chromatophores. Nucleus posterior. Length $22-27 \mu$, breadth $18-21 \mu$. In the older specimens the margins of the valves are striated. Very minute tooth-like processes may occur at the anterior end. In coastal waters and far out to sea. Occurs abundantly, but is so minute that it is easily overlooked.

North Sea, Skaggerak, Adriatic, English Channel; occurred at Plymouth from the surface to 20 fathoms, chiefly in spring and summer. Schiller (1918) found his E. bisimpressa, which is presumably this species, as far down as 150 metres in the Adriatic.

\section{Exuviella apora Schiller (1918).}

Plate I, figures $4 \mathrm{a}-4 \mathrm{c}$.

Like $E$. perforata in shape but without the conical indentations in the centres of the valves. The two pores are present anteriorly as in that species; striated margins in the older Plymouth specimens. No poroids round the margin. Two yellow-brown chromatophores, sometimes breaking up into small spheres. Length $16-22 \mu$ in the Plymouth specimens, $30-32 \mu$ in those from the Adriatic.

Occurs in deep water in the open sea in the Adriatic, close to shore near Plymouth, and in the Yealm estuary, near Plymouth, in summer. It is possible that there are here two separate species, but the Plymouth specimens are so like Schiller's figures that it is difficult to separate them.

Exuviella baltica Lohmann (1908).

Text-figure 4a.

Paulsen, 1908; Nordisches Plankton, p. 108.

A minute species, roundish oval, somewhat flattened from side to side. One to several chromatophores, golden yellow, branched, often covering the inner wall of the theca. Plasma or cell contents milky, containing numerous refractive bodies. Length $9-14 \mu$.

From the Baltic at Kiel, where Lohmann (1908) found it with a 
maximum in May of four million individuals to a litre; also from the White Sea (Wulff, 1916).

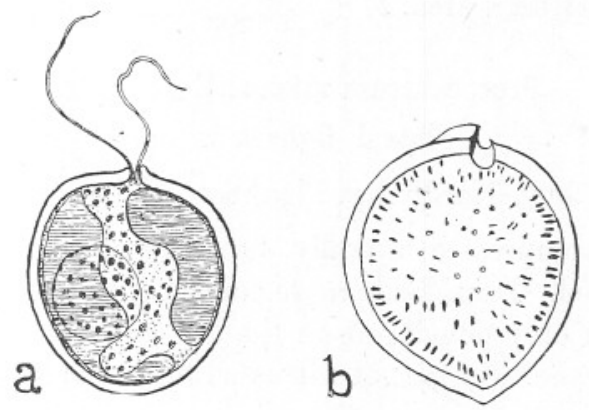

Fig. 4.

a. Exuviella baltica Lohmann.

$14 \mu$ long, White Sea. After Wulff, 1916.

b. Prorocentrum scutellum Schroeder.

$45 \mu$ long, Adriatic. After Schiller, 1918.

\section{Genus Prorocentrum Ehrenberg.}

Cell oval or somewhat heart-shaped, compressed laterally. Flagella emerge from a slit between the valves by the side of which is a strong tooth-like process, which may be solid or hollow and occur in both valves, or in one only. Valves with poroids on the surface of the theca.

Species:-Prorocentrum dentatum Stein, P. micans Ehrenberg, and P. scutellum Schroeder.

\section{Prorocentrum dentatum Stein.}

\section{Text-figure 5 .}

Paulsen, 1908; Nordisches Plankton, p. 7.

Cell an oval, pointed at the posterior end, broadest in front of the
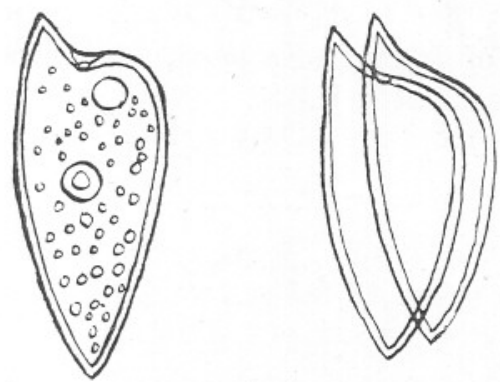

Fig. 5. Prorocentrum dentatum Stein.

Locality (?). Length (?). After Stein, 1883. 
centre. Both valves similar, each bearing a three-cornered tooth-like hollow process which together form the dorsal horn. Length (?).

Rare in the Northern area.

Prorocentrum micans Ehrenberg.

Plate I, figures 5a-5c.

Paulsen, 1908; Nordisches Plankton, p. 8.

Cell strongly compressed laterally, broadest about the middle, somewhat heart-shaped. Dorsal side more convex than the ventral and bearing a solid tooth only developed on the left valve and provided with a wing-like membrane. Surface of valves with minute poroids all over and scattered spines from near the centre to the posterior end. Length $36-48 \mu$ (without spine). Neritic and estuarine.

Very widely distributed and often also occurring in the open sea. Forms an important part of the food of shell-fish such as the oyster and mussel ; also of plankton-feeding fishes such as the pilchard. Dr. Orton, of the Plymouth Laboratory, has often found it inside sponges. Megacytic forms occur.

Widely distributed throughout the northern area. In the Channel and also in the Baltic and Danish seas its maximum is in the late summer; in the Mediterranean it is in the spring. Has been recorded from the Black Sea, Bosphorus, Gulf of Siam and Japan, and Woods Hole, Massachusetts, U.S.A.

Prorocentrum scutellum Schroeder (1901).

Text-figure 4b.

Paulsen, 1908; Nordisches Plankton, p. 8.

Cell broadly heart-shaped, slightly indented in front, with a distinct spine on the left valve with an extremely thin wing. Poroids, large and small, together with small spines, scattered all over the valves. Length $40-57 \mu$.

Atlantic, south of Iceland, Kattegat, Mediterranean, Adriatic and Woods Hole, Massachusetts, U.S.A. 


\section{Order DINIFERIDEA Kofoid and Swezy.}

With a girdle. Body naked or with a theca composed of three or more parts.

Tribe GYMNODINIOIDAE Poche (emended by Kofoid and Swezy).

Cell naked or covered with a thin pellicle, with longitudinal and transverse flagella located respectively in sulcus and girdle. Sometimes enclosed temporarily or permanently in a gelatinous or cellulose cyst usually without a girdle. Freshwater and marine. Holophytic, saprophytic, holozoic and parasitic.

Thanks to the magnificent monograph by Kofoid and Swezy (1921) on the unarmoured dinoflagellates, a very great deal has been added to our knowledge of these forms which include some of the most interesting and most beautiful in the whole group. The simplest of these are very near the cryptomonad flagellates from which they are probably derived; the most highly developed are so near the Metazoa that they seem to be the climax in the evolution of the dinoflagellates. In Kofoid and Swezy's work they are placed at the base of the group, arising through forms such as Pronoctiluca (the Protodinifer of Kofoid and Swezy) and Oxyrrhis from some simple flagellate, and running up to the very top of a branched tree, which, giving off laterally all the other forms, finishes at the top in Erythropsis, with its complicated system of lenses and enormous "prod." Erythropsis itself has not yet been found in the present area. Paulsen (1908) places all the naked forms last in his elassification. Kofoid and Swezy place them first in the Diniferidea, and this arrangement is followed here.

The Gymnodinioidae as a rule do not form so large a part of the plankton of northern waters as they do in the warmer seas, although in certain cases large swarms of them are to be found. Enormous masses occur living in sand, especially the genus Amphidinium. The more highly organised genera are usually found singly or only a fèw in a sample. They are not so highly coloured as the southern forms and are usually smaller. Much depends on the individual observer as to the colour described. The hyaline species may be colourless, or have a greenish yellowish or bluish tinge. On the whole, Northern forms seem to be more often colourless, although a few are brightly coloured.

\section{Family PRONOCTILUCIDAE nom. nov.}

Protodiniferidae Kofoid and Swezy.

Cell with rudimentary girdle and sulcus. Flagella anterior or ventral. 
Tentacle more or less developed. Marine. Neritic; from warm temperate waters. The family Protodiniferidae was founded by Kofoid and Swezy to include their Protodinifer (here called Pronoctiluca) and Oxyrrhis. These are regarded by the above authors as the most primitive of the Gymnodinioidae, forming a connecting link between the Diniferidea and the Adiniferidea.

\section{Genus Pronoctiluca Fabre-Domergue (1889).}

Protodinifer Kofoid and Swezy (1921).

Pelagorhynchus Pavillard (1917).

Unfortunately the genus Protodinifer of Kofoid and Swezy must give place to Pronoctiluca of Fabre-Domergue. In 1917, Pavillard pointed out that Lohmann's Rhynchomonas marina belonged to a new genus which he named Pelagorhynchus. Later, however (1922), he showed that Fabre-Domergue had already described it (1889) as Pronoctiluca pelagica. In the first paper (1917) Pavillard shows that the species has two flagella, a tentacle, a punctuated pellicle, and a nucleus the structure of which is like a dinoflagellate. He was therefore the first to point out its dinoflagellate affinities. The genus may be described thus :-

Cell with a ventral anterior tentacle and sulcus, anterior girdle feebly developed. Long thread-like transverse flagellum, short or long longitudinal flagellum.

Pronoctiluca pelagica Fabre-Domergue (1889).

Text-figure 6.

Pelagorhynchus marina Pavillard (1917).

Protodinifer marinum Kofoid and Swezy (1921).

Cell spindle-shaped or pear-shaped; length about $2 \frac{1}{2}$ transdiameters. Tentacle slender, terminal. Girdle and sulcus anterior. Both flagella long, one anterior, one posterior. Punctuated membrane covering cell. Nucleus with large bead-like chromatin granules; large yellow mass posterially. Encystment occurs in a thin closely adherent membrane from which the tentacle protrudes. Later the cyst expands into a sphere and the body assumes a pear-shape within it. Length $12-45 \mu$. Marine.

Coast of Brittany, Gulf of Lions, Cette, Bay of Kiel ; found inside appendicularians from the Baltic.

\section{Genus Oxyrrhis Dujardin (1841).}

Body somewhat oval, asymmetrically contracted posteriorly to the left. Girdle behind the centre, incomplete dorsally and lacking a posterior 

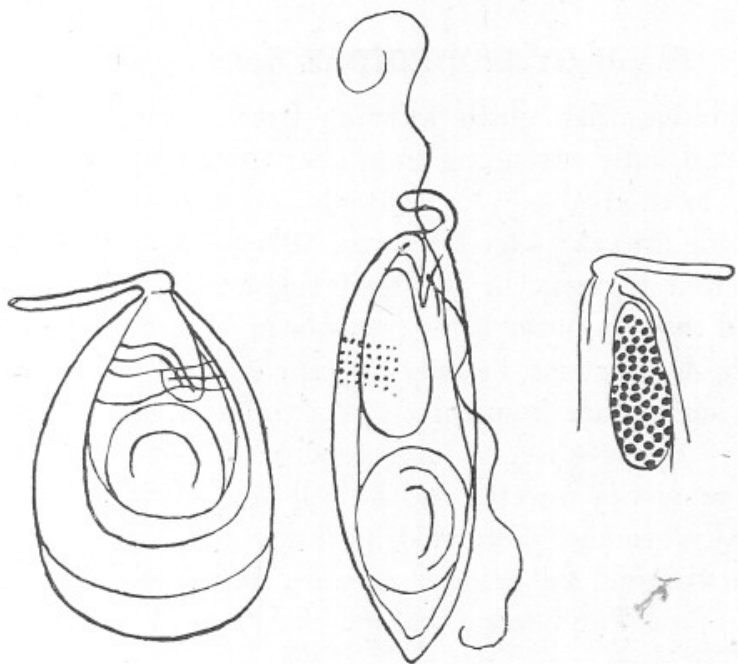

FIG. 6. Pronoctiluca pelagica Fabre-Domergue.

$\times$ 1000. Gulf of Lions, Cette. After Pavillard, 1917.

margin. Sulcus spreading ventrally and posteriorly, divided in front by a lobe, the tentacular lobe. The transverse flagellum, not like a ribbon but simple, springs from the left of this lobe, the longitudinal flagellum from the right. Nucleus with beaded chromatin. Marine. Reproduction by oblique fission, almost transverse, with subsequent chain formation of two individuals. The tentacular lobe is regarded by Kofoid and Swezy as perhaps homologous with the tentacle of Protodinifer.

Oxyrrhis marina Dujardin (1841).

Plate I, figures 6a-6e.

Kofoid and Swezy, 1921 ; pp. 117-119.

Body elongate-oval ; flagella mid-ventral, stout tentacular lobe hanging between the two flagella, dividing the undeveloped sulcus. Colourless, holozoic. Length $10-37 \mu$ (usually $22-33 \mu$ ).

White Sea, harbours of Genoa and Marseilles, Kiel harbour, Plymouth Sound, Jersey; also salt lakes of Kharkoff, Russia, North and South America. Common in laboratory cultures. In the Plymouth culture it was often feeding on Nitzschia closterium, the diatom usually used to make cultures for food in the rearing of marine animals ; on one occasion it was feeding on a cryptomonad.

The movement is a forward jerky one, somewhat rolling. The longitudinal flagellum is easily cast off if in unnatural surroundings. For a detailed account of this species and its division, see Hall (1924). 


\section{Family GYMNODINIIDAE Kofoid (1907c).}

Gymnodinioidae with girdle varying from $\frac{1}{2}$ to 4 turns round the body. Sulcus usually extending from near the apex to near the antapex and may be twisted also. No tentacle, no ocellus. Pusules may be present opening into the flagellar pores. Plasma may contain chromatophores, coloured pigment or be itself coloured. The plasma may be differentiated into an outer layer (ectoplasm) and an inner layer (endoplasm), or the former may be only a thin covering. Longitudinal striae on the body surface are frequent. Cyst formation often occurs either as a consequence of ingestion of large food bodies or as a preliminary to division. The cyst is secreted by the cell and, at first closely adherent, often gradually becomes distended by fluid.

Fresh, brackish and salt water; oceanic, neritic and littoral (occurring on the shore); cold and warm waters.

\section{Genus Hemidinium Stein (1883).}

Cell with incomplete girdle of half a turn. Fresh water; rarely in brackish water.

\section{Hemidinium nasutum Stein (1883).}

Text-figure 7 .

Paulsen, 1908; Nordisches Plankton, pp. 94-95.

Kofoid and Swezy, 1921 ; pp. 122-123.

Body asymmetrically oval. Girdle median, a descending left spiral of half a turn. Sulcus confined to the hypocone, reaching to the posterior margin. Chromatophores yellow or brown. Nucleus posterior. Length $24-28 \mu$.

Fresh water in Europe from the Tyrol to Finland; Prague, salt lakes near Odessa; Bosphorus. Rare in brackish water in Finland.
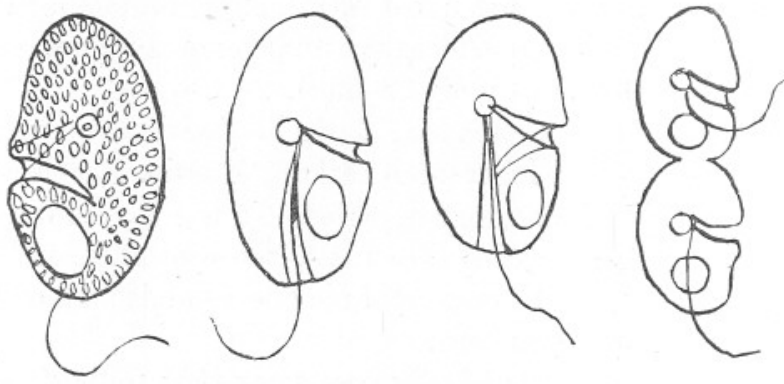

FIG. 7. Hemidinium nasutum Stein.

Size (?). Near Prague. After Stein, 1883. 


\section{Genus Amphidinium Claparède and Lachmann (1858-61).}

Body usually compressed dorso-ventrally, sometimes laterally, or it may be round in section. Girdle far anterior with little or no displacement. Sulcus extending either from the girdle to the hypocone, or invading the epicone, usually not twisted. Epicone relatively minute, usually asymmetrical. Pusules may be present. Plasma colourless with or without chromatophores, or coloured without chromatophores. Surface smooth or with fine striae, furrows or ridges. Outer pellicle may be thick, especially in those forms which are flattened laterally. The lips of the sulcus, or more usually one of them, often form flaps, or a flap, making the sulcal area extremely mobile. Encystment in thin-walled membrane may occur. Nutrition chiefly holophytic, sometimes holozoic. Marine, freshwater and brackish ; oceanic, neritic or littoral ; warm or cold waters.

The species of this genus are mostly shore forms, but a few, and these the largest, are pelagic. Many live in sand between tide marks, and these are specially adapted to their habitat in being much flattened and usually with a deep sulcal groove, often with flaps by means of which they cling to the sand grains. Most of these have yellow chromatophores, causing them, when massed together, to appear brown.

In these sand-loving forms, many species of which come to the surface when the sand is uncovered at low tide, there is found by Miss Herdman to be a daily rhythm depending on light and tide, a dim light, such as occurs in the morning and evening when the sky is overcast, producing the largest masses of these organisms. Besides this daily rhythm she finds a lunar rhythm, where the largest number occur at Spring, the fewest at Neap tides.

Kofoid and Swezy suggest the subdivision of the genus into two subgenera, Amphidinium proper with the body compressed dorso-ventrally, and Rotundinium with the body not compressed. They are of the opinion that a third sub-genus might be necessary for laterally flattened forms. Without using these sub-generic names the species are here divided into these three groups, dorso-ventrally flattened, round in section, and laterally flattened.

These laterally flattened forms have been found abundantly at Port Erin by Miss Herdman, the covering pellicle being very thick. On examination of these the variety petasatum of Amphidinium Kofoidi C. Herdman was seen to be so closely related to the Dinophysidae, in that it can be separated by reagents into two halves bound together by a marginal piece which can be separated, and in having the girdle also detachable, that it is probably a dinophysid. At any rate, it has affinities with both Amphidinium and Phalacroma or Dinophysis and seems to corroborate, 
as Miss Herdman states (1924), what Kofoid and Swezy (1921) have suggested, namely, that Amphidinium is closely related to the Dinophysidae.

Species : 1. Dorso-ventrally flattened forms.

Amphidinium operculatum Claparède and Lachmann, A. Steini Kofoid and Swezy, A. Klebsi Kofoid and Swezy, A. ovoideum Lemmermann, A. Herdmanni Kofoid and Swezy, A. latum n.sp., A. scissum Kofoid and Swezy, A. britannicum C. Herdman, A. flexum C. Herdman, A. pellucidum C. Herdman, A. testudo C. Herdman, A. bipes C. Herdman, A. ovum C. Herdman, A. discoidalis Diesing, A. emarginatum Diesing.

2. Non-flattened forms.

A. scissoides n.sp., A. crassum Lohmann, A. phaeocysticola n.sp., A. longum Lohmann, A. pelagicum n.sp., A. extensum Wulff, A. sphenoides Wulff.

3. Laterally flattened forms.

A. eludens C. Herdman, A. Kofoidi C. Herdman, A. semilunatum C. Herdman, A. manannini C. Herdman, A. vitreum C. Herdman.

\section{Dorso-ventrally Flattened Forms}

Amphidinium operculatum Claparède and Lachmann (1858-61). Text-figure 8a (see p. 24).

Kofoid and Swezy, 1921, p. 147.

Cell oval, its length 1.5 transdiameters. Girdle running down posteriorly on the ventral surface for about a third the length of the cell. Sulcus extending from girdle to antapex. Epicone minute, triangular, asymmetrical, turning to the left. Hypocone broadly rounded. The two flagella arise near one another at the point of junction of girdle and sulcus. Nucleus not known. Chromatophores yellow-brown, radiating from a central body. Length $40-50 \mu$.

Coast of Norway, Sweden, Hungary in salt pools, Belgium, in cultures of sea-water at Roscoff, Brittany; Woods Hole, Massachusetts.

Kofoid and Swezy regard this as a separate species from A. Klebsi and A. Steini: out of deference to these authors they are here kept apart. I feel, however, very doubtful as to these being separate species. A. Klebsi, the only one of the three seen by the writer, occurs very commonly and certainly is more like the figure of $A$. Klebsi than the others. At the same time specimens have been seen which closely resemble Stein's figure of the so-called A. Steini and also of Calkin's A. operculatum. Further research may bring all three together as $A$. operculatum. 
Amphidinium Steini Kofoid and Swezy (1921).

Text-figure $8 \mathrm{~b}$.

Amphidinium operculatum var. Steini Lemmermann (1902).

This is the Amphidinium operculatum of Stein, who figured it from brackish water near Wismar, Germany. Body oval, somewhat pointed posteriorly. Girdle running on to hypocone for nearly half its length. Sulcus extending from girdle to apex. Epicone small, cap-like, asymmetrical, turning to left. Nucleus posterior. Chromatophores brown, radiating from a central body. Length ca. $45 \mu$ (calculated).

Brackish water near Wismar, Germany.

Amphidinium Klebsi Kofoid and Swezy (1921).

Plate II, figure 1.

Amphidinium operculatum Paulsen, 1908; Nordisches Plankton, p. 95 .

Cell oval, rounded posteriorly, girdle running down the hypocone for nearly half its length, sulcus extending from girdle obliquely to the right, ending on the right side. Epicone tongue-shaped, deflected to the left. Flagella pores close together near the junction of girdle and sulcus. Nucleus large, oval, posterior. Yellow chromatophores radiating from a central mass sometimes behind the centre. Surface of cell sometimes faintly striate. At the anterior part of the epicone is an orange spot. Holophytic. Living in sand uncovered by the tide or near the coast. Length $30-36 \mu$. This is the commonest species in the sand at Cullercoats, and also occurs at Port Erin, where Miss C. Herdman finds it almost merging into A. Herdmanni.

Port Erin, Isle of Man ; Cullercoats, Northumberland ; Bay of Naples.

Amphidinium ovoideum Lemmermann (1896b).

Text-figure 8c.

Kofoid and Swezy, 1921, p. 148.

A minute species. Body broadly oval. Girdle anterior, not defined. Sulcus (?). Epicone tongue-shaped, deflected to left(?). Hypocone rounded. Cell filled with minute brown chromatophores. Nucleus posterior. Length $17-23 \mu$.

Brackish water along the border of the Baltic, near Plön, Germany.

Amphidinium Herdmanni Kofoid and Swezy (1921).

Plate II, figures 2a-2c.

Kofoid and Swezy, 1921, p. 143.

Cell broadly ellipsoidal, much compressed dorso-ventrally. Girdle 
DINOFLAGELLATA
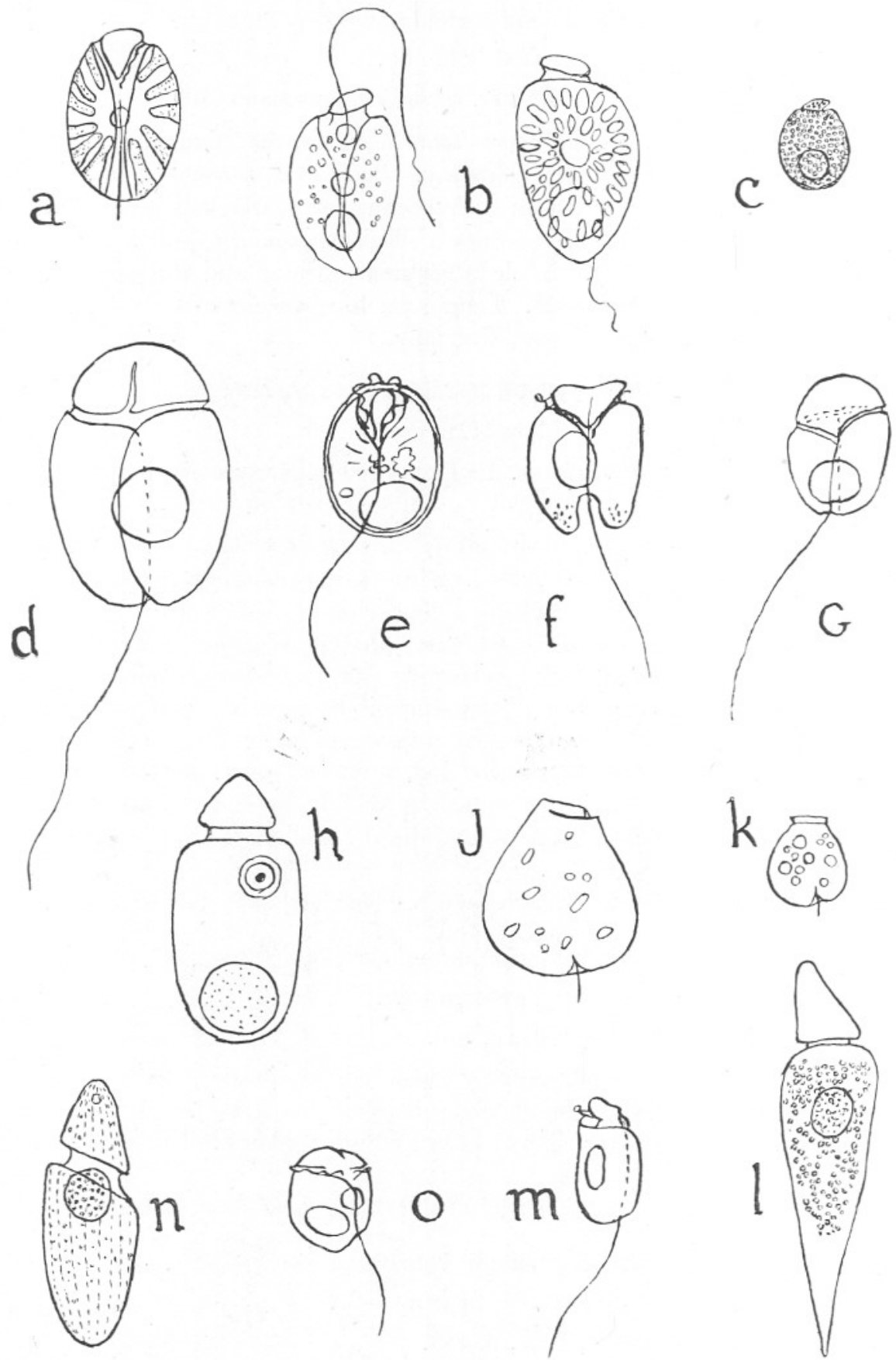

FIG. 8. 
FIG. 8.

a. Amphidinium operculatum Clap. and Lach.

$45 \mu$ long, Woods Hole, Mass. After Calkin, from Kofoid and Swezy, 1921.

b. Amphidinium Steini Lemmermann.

$45 \mu$ (calc.), Wismar. After Stein, 1883.

c. Amphidinium ovoideum Lemmermann.

$23 \mu$, Plon, Germany. After Lemmermann, 1896.

d. Amphidinium pellucidum C. Herdman.

ca. $60 \mu$, Port Erin, Isle of Man. After C. Herdmann, 1922.

e. Amphidinium testudo C. Herdman.

$30 \mu$ long, sand at Port Erin, Isle of Man. After C. Herdman, 1924.

f. Amphidinium bipes C. Herdman.

$30 \mu$ long, sand at Port Erin, Isle of Man. After C. Herdman, 1924.

g. Amphidinium ovum C. Herdman.

$30 \mu$ long, sand at Port Erin, Isle of Man. After C. Herdman, 1924.

h. Amphidinium longum Lohmann.

$35 \mu$ long, Barents Sea. After Wulff, 1916.

j. Amphidinium discoidalis Diesing.

$47 \mu$ long, North Sea, Norway coast. After Claparède and Lachmann, 1858.

k. Amphidinium emarginatum Diesing.

$24 \mu$ long, North Sea, Norway coast. After Claparède and Lachmann, 1858.

l. Amphidinium sphenoides Wulff.

40 to $50 \mu$ long. Barents Sea. After Wulff, 1916.

m. Amphidinium vitreum C. Herdman.

$20 \mu$ long, sand at Port Erin, Isle of Man. After C. Herdman, 1924.

n. Amphidinium extensum Wulft.

30 to $50 \mu$ long, Barents Sea. After Wulff, 1916.

o. Amphidinium manannini C. Herdman.

$20 \mu$ long, sand at Port Erin, Isle of Man. After C. Herdman, 1924. 
running ventrally on to hypocone for rather more than a third of its length. Sulcus extending from girdle to apex, the left side sometimes slightly longer than the right, or vice versa. Hypocone rounded posteriorly and slightly notched by the sulcus. Epicone small and flattened anteriorly, triangular ventrally, deflected slightly to left. Flagella pores close together near the junction of girdle and sulcus. Nucleus crescentshaped, large, posterior. Bright yellow chromatophores radiating from a central mass. In some specimens from Cullercoats two red spots were present one on each side of the centre and the plasma was full of starch grains. Holophytic. Length $28-50 \mu$.

This is a typically sand-loving species. It was originally found by the late Sir William Herdman (1911) on the sands at Port Erin and described by him as Amphidinium operculatum. Miss C. Herdman has continued to investigate and describe its habits, which are very interesting (19211922-1923). It occurs also on the Cullercoats beach, but is not so common there as $A$. Klebsi.

\section{Amphidinium latum n.sp.}

\section{Plate II, figure 3.}

A minute species found in a Petri dish in which were placed Amphidinium Klebsi in water sent from Cullercoats. Body round in ventral view, slightly longer than broad, much flattened dorso-ventrally. Very short and flat epicone, slightly rounded. Antapex rounded. Plasma clear and colourless, smooth. Girdle wide, very slightly left-handed, much excavated, the anterior flagellar pore at the junction of girdle and sulcus. Sulcus running up to the apex so as to notch the epicone slightly, and down to the posterior end of the hypocone, narrowest at the centre. Longitudinal flagellum emerges near the transverse one, longer than the body. Nucleus anterior, an unusual position in this genus, but green food cells occurred posteriorly in all the specimens which may have pushed the nucleus forwards. Holozoic. Length 15-19 $\mu$.

Sea water from beach at Cullercoats, Northumberland; sand at Port Erin, Isle of Man.

\section{Amphidinium scissum Kofoid and Swezy (1921). Plate II, figure 4.}

Kofoid and Swezy, 1921, p. 150.

Body elongated ovate, compressed dorso-ventrally, widest near the centre. Epicone flattened, asymmetrical, turning to the left. Girdle displaced about two girdle widths, left-handed. Sulcus runs from apex to antapex, notching the apex, and running to the dorsal surface, sometimes to join the girdle, and widens posteriorly to show a rounded excava- 
tion. Transverse flagellum emerges from anterior pore at junction of girdle and sulcus, and runs round the girdle: longitudinal flagellum emerges about two-thirds of the way down the hypocone. Nucleus large, posterior. Striations in American form, but none seen in the British form. No chromatophores. Colourless or greenish with round refractive bodies. Length $50-60 \mu$.

In sand from La Jolla, California; beach at Port Erin, Isle of Man. Not very common.

Amphidinium britannicum C. Herdman (1922).

Plate II, figures 5 and 6.

Amphidinium asymmetricum var. britannicum C. Herdman.

Body much flattened dorso-ventrally, asymmetrically oval, longest on the left. Apex and antapex rounded. Epicone very asymmetrical, longest on the right. Girdle a steep spiral. Sulcus confined to the hypocone with a flap, rounded posteriorly, on the left side, overhanging the right. Nucleus central. Yellow chromatophores radiating from the centre. Surface smooth. Length $37-60 \mu$. Miss Herdman, whilst assigning this species to Kofoid's $A$. asymmetricum as a variety, notes the difference; this is chiefly the dorso-ventral flattening, and absence of striae. The so-called chromatophore appears to me to be a mass of several small elongated chromatophores radiating from a centre: this seems more probable as the variety compacta also described by her from Port Erin has two centres from which the chromatophores radiate, one anterior and one posterior, leaving a clear band in the centre where the nucleus is situated. The variety compacta is slightly darker and smaller without such a conspicuous flap to the left of the sulcus, which is slightly to the right of the mid-ventral line.

Sand at Port Erin, Isle of Man.

Amphidinium flexum C. Herdman (1923).

Text-figure 9a (see p. 28).

Body flattened dorso-ventrally and slightly twisted, the left posterior region deflected dorsally, the right deflected ventrally. Length 1.5 transdiameters. Epicone at most equal in width to the greatest transdiameter ; its length in the ventral region about 0.26 of the total length. Apex rounded. Hypocone broadly sac-shaped and slightly notched by the sulcus. Girdle almost symmetrical, rising gently to the mid-dorsal region, its two ends meeting without displacement. Transverse flagellum completely encircling the body. Sulcus extending almost from the apex to the antapex. Longitudinal flagellum extending beyond the antapex for 
a distance nearly as great as the whole length of the body. Nucleus. posterior. Plasma uncoloured, but full of small yellowish brown granules. Length ca. $60 \mu$.

Occurs from time to time, but never in numbers, on the beach at Port Erin. (C. Herdman.)

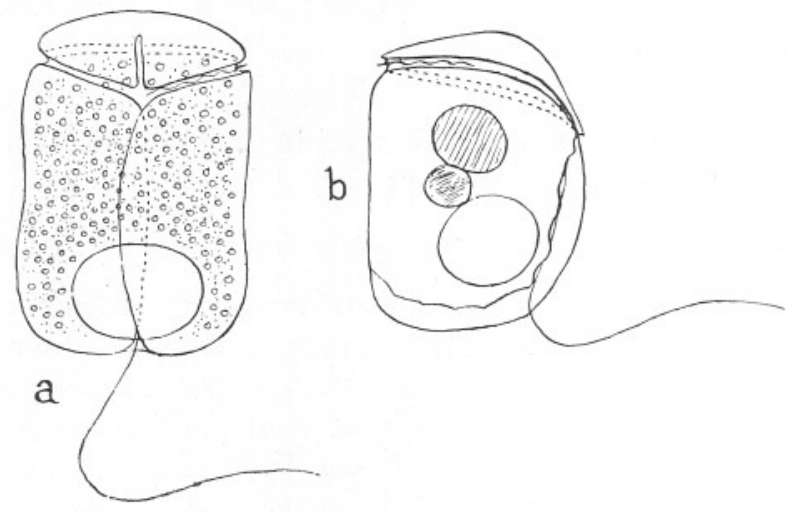

FIG. 9.

a. Amphidinium flexum C. Herdman.

ca. $60 \mu$, Port Erin, Isle of Man. After C. Herdman, 1923.

b. Amphidinium semilunatum C. Herdman.

ca. $50 \mu$ long, Port Erin, Isle of Man. After C. Herdman, 1923.

Amphidinium pellucidum C. Herdman (1922).

Text-figure 8d.

Body almost symmetrical, broadly elliptical, flattened dorso-ventrally. Epicone much smaller than hypocone, almost semicircular in ventral view, sometimes slightly notched by sulcus. Hypocone broadly sacshaped, rounded and notched posteriorly. Girdle deep, rising very little on the dorsal side, its ends meeting almost without displacement. Transverse flagellum completely encircling the body. Sulcus extending from apex to antapex, very broad just posterior to the girdle, but overhung by projections from either side. Longitudinal flagellum usually lying within the sulcus and extending beyond the antapex for a distance nearly as great as the whole length of the body. Plasma colourless and of glassy transparency. Nucleus probably situated near the centre of the body to the left of the middle line. Coloured (usually red) bodies, which probably consist of food matter, often present in the region of the sulcus. Length 50-60 $\mu$.

In scrapings of sand containing coloured dinoflagellates, Port Erin. (C. Herdman.) 
Amphidinium testudo C. Herdman (1924).

Text-figure $8 \mathrm{e}$.

Broad, ellipsoidal, much flattened, ventrally flat or slightly concave, dorsally convex. Epicone very small, not projecting beyond the dorsal rim of the hypocone, extending ventrally at least one-third of the body length. Sulcus short, not extending on to the epicone nor reaching the antapex. Girdle deeply impressed. Dorsal rim of hypocone bent outwards as a projecting lip below the girdle. Nucleus posterior. Protoplasm colourless with yellow chromatophores and granules radiating from the centre of the body. Often one or more irregular, dark, highly refractile bodies are present. A colourless pellicle surrounds the body. Length $20-30 \mu$.

Sand at Port Erin, Isle of Man; also Wood's Hole, Massachusetts. (C. Herdman.)

Amphidinium bipes C. Herdman (1924).

Text-figure $8 f$.

Length about 1.4 transdiameters. Epicone roughly triangular, very slightly concave anteriorly and highest at the left side. Hypocone large and more convex on the right than on the left, very deeply notched at the antapex. Sulcus a broad shallow furrow on the hypocone and continued forward as a narrow groove on the epicone. Longitudinal flagellum long, free from its origin and often turned forwards. Cell colourless and granular, with dark brownish green granules in the posterior horns. A highly refractile body sometimes present just anterior to the antapical notch. Nucleus to the right near the centre. Length ca. $30 \mu$.

In sand at Port Erin, Isle of Man. (C. Herdman.)

\section{Amphidinium ovum C. Herdman (1924).}

Text-figure $8 \mathrm{~g}$.

Cell ellipsoidal. Girdle rising to the left shoulder and thence running in a descending spiral to join the sulcus about 0.4 of the body length from the apex. Sulcus running from the girdle to the antapex as a groove which is deeply overlapped by its left margin. From the antapex it is continued as a narrow furrow up the dorsal side almost to the level of the girdle. Longitudinal flagellum about twice as long as the body. Nucleus posterior. Yellowish brown chromatophores radiating from the centre. Length ca. $30 \mu$.

In sand at Port Erin, Isle of Man. (C. Herdman.) 
The two following insufficiently known species probably belong to this group :--

\section{Amphidinium discoidalis Diesing (1866).}

Text-figure $8 \mathrm{j}$.

Kofoid and Swezy, 1921, p. 139.

A small species with broadly ovoidal body. Girdle far anterior. Sulcus not shown, except at posterior end, from which the longitudinal flagellum appears. Colourless. Length $47 \mu$.

North Sea; Norway coast.

\section{Amphidinium emarginatum Diesing (1866).}

Text-figure $8 \mathrm{k}$.

Kofoid and Swezy, 1921, p. 140.

Minute, like $A$. discoidalis. Length $24 \mu$.

North Sea; Norway coast.

The two following probably belong to the next group of non-flattened forms, but are not sufficiently characterised. Both are described by Wulff from the Barents Sea :-

\section{Amphidinium extensum Wulff (1916).}

Text-figure $8 \mathrm{n}$.

Cell elongated, with an oblique girdle. Epicone small, hypocone long. No sulcus described. Nucleus anterior. Surface striated. Colourless. Length $30-50 \mu$. This is perhaps identical with Schütt's Gymnodinium vestificii, and thus possibly the same as Gyrodinium glaucum (see below).

Barents Sea.

\section{Amphidinium sphenoides Wulff (1916).}

Text-figure 81 .

Cell spindle-shaped, with triangular small epicone, very much excavated girdle and long hypocone. No sulcus described. Hypocone ending in a long drawn-out point. Nucleus sub-central. Length 40-50 $\mu$. Possibly identical with Gymnodinium filum (see below).

\section{Non-flattened Forms}

\section{Amphidinium scissoides n.sp.}

Plate III, figure 1.

This species was only seen once and unfortunately collapsed before 
being properly worked out. Body elongated, sub-cylindrical. Section almost round. Epicone flattened, very small, asymmetrical, turning to left, notched at the apex by the sulcus, which reaches the whole length of the body, widening posteriorly to show a rounded swelling. Girdle displaced about four girdle widths, directed posteriorly on the ventral surface, far anterior dorsally. Flagella not seen. Very large yellow food mass inside the body. Nucleus not seen. Plasma colourless. Length $70 \mu$.

Off Eddystone grounds, in October, 1923.

This species closely resembles A. scissum, but is hardly flattened, so that it belongs to those with a round body section.

\section{Amphidinium crassum Lohmann (1908).}

Plate III, figures 2a-2c.

Paulsen, Nordisches Plankton, 1908, p. 96.

Kofoid and Swezy, 1921, p. 135.

Body broadly oval, rounded or somewhat pointed posteriorly, pointed anteriorly, nearly circular in section; length 1.5 transdiameters or more at the widest part, which is at about the centre of the body. Epicone minute, cap-like, slightly notched by the sulcus at the apex. Girdle wide, very slightly left-handed, deeply excavated. Sulcus running from just over the apex to nearly the end of the hypocone, widest in the middle. Anterior flagellar pore at the junction of girdle and sulcus with long transverse flagellum encircling the whole girdle. Posterior pore almost in the centre of the body about a girdle width below the girdle. Very long longitudinal flagellum. Large nucleus, posterior. Holozoic. Plasma clear and colourless, usually green food masses inside. Body covered with a distinct pellicle which sometimes comes away from the plasma. Smooth. Length 27-30 $\mu$. Neritic.

Kiel, Plymouth Sound, common. Also occurs in the Channel.

\section{Amphidinium phaeocysticola n.sp. \\ Plate III, figures $3 \mathrm{a}-3 \mathrm{c}$.}

Closely related to $A$. crassum, but larger and with striated body and slightly twisted antapex. Broadly oval, not so pointed behind as A. crassum, with irregular protuberances. Clear and colourless, feeding on the flagellate Phaeocystis which is nearly always inside it. Body striated with fine striae, near together on the epicone, far apart on the hypocone, often with roundish masses (food products ?) arranged along the lines. Girdle far anterior, deeply excavated, slightly left-handed. Anterior flagellar pore at the junction of girdle and sulcus. Sulcus running up to the top of the epicone and nearly to the end of the hypocone, widest about the centre. Posterior flagellar pore about a girdle width 
from the girdle. Longitudinal flagellum very long. Nucleus large, posterior. Length $42 \mu$. This species has been seen to encyst in thinwalled cysts in which it divides.

In spring and early summer, living among Phaeocystis; Plymouth Sound.

Amphidinium longum Lohmann (1908).

Text-figure $8 \mathrm{~h}$.

Paulsen's Nordisches Plankton, 1908, p. 96.

Kofoid and Swezy, 1921, p. 146.

A minute species, like an elongated $A$. crassum. Body sub-ovate, widest anteriorly behind the girdle. Epicone minute, triangular, apex pointed. Girdle broad, deeply excavated. Hypocone broad anteriorly, tapering posteriorly to a narrow rounded apex. Sulcus not known. Nucleus posterior. Food mass near the girdle. Colourless. Holozoic. Length $25-35 \mu$.

Kiel, Barents Sea, Adriatic.

\section{Amphidinium pelagicum n.sp. \\ Plate III, figures $4 \mathrm{a}-4 \mathrm{c}$.}

This species only occurred once and only one individual was seen. Fairly large species, its length just over two transdiameters at its greatest breadth behind the centre. Nearly circular in section. Epicone relatively small, cap-like, asymmetrical. Hypocone about twice as long as the longest part of the epicone. Girdle anterior, slightly displaced and lefthanded, narrow. Sulcus shallow anteriorly, deepening and widening posteriorly, the left lip forming a flap so that most of the furrow is hidden ; running half-way up the epicone and to the extreme posterior end of the hypocone, slightly notching it. Surface of body furrowed on the hypocone. Anterior flagellar pore at the front junction of girdle and sulcus, posterior pore not seen. Nucleus large, posterior. Plasma colourless, with bright yellow-green chromatophores radiating from the centre of the cell, chiefly in the hypocone. Length $84 \mu$.

English Channel, 5 miles S.W. of Plymouth. June.

\section{Laterally Flattened Forms}

Amphidinium eludens C. Herdman (1922).

Plate III, figure 5.

Body nearly symmetrical, flattened laterally. Epicone very small and imperfectly divided from hypocone. Girdle asymmetrical, passing in an anterior direction slightly to the left of the middle line. At the extreme 
apex the girdle crosses the middle line and continues dorsally, now slightly to the right and gradually fades out, the transverse flagellum passing round the body to the left side at a distance from the apex of rather more than a quarter of the body length. Sulcus extending to within one transdiameter of the antapex and partly overhung by the projecting left border. Longitudinal flagellum hardly any longer than the body and often lying free from the anterior end of the sulcus. Body enclosed in a distinct homogeneous and colourless pellicle, from which, under adverse conditions, the cytoplasm may be retracted. Two highly refractive bodies, having the appearance of the amyloid bodies of the Adiniferidea, occur, one on each side. Protoplasm of a uniform yellowochre colour. Nucleus posterior and slightly dorsal, elongated and often gently curved to fit the contour of the body. Length $30-32 \mu$.

Sand at Port Erin, Isle of Man. (C. Herdman.)

\section{Amphidinium Kofoidi C. Herdman (1922).}

Plate III, figure 6.

Body slightly asymmetrical and broadly ellipsoidal, the dorso-ventral axis being about 0.8 of the total length; flattened laterally and more convex on the ventral than on the dorsal side. Epicone small and sometimes retracted so as to be hidden in lateral view between the projecting edges of the hypocone. Hypocone sac-shaped, with its greatest width (dorso-ventrally) at about $0 \cdot 4$ of the total length from the posterior end. Left border of the sulcus projecting beyond the right in the anterior ventral region. Girdle deep, its two ends meeting without displacement. Sulcus not extending as far as the antapex nor continued upon the epicone. Transverse flagellum completely encircling the body and usually easily visible projecting beyond the margins of the girdle. Posterior flagellum extending beyond the antapex and lying with its proximal part in the sulcus. Body enclosed in a colourless homogeneous pellicle. Two amyloid bodies (?), situated one at about the middle of each side. Numerous small refractile granules usually present throughout the cytoplasm, which is a uniform light brown colour. Nucleus posterior and slightly dorsal, very slightly elongated and with the side next the surface of the body more convex than the inner side. Anterior part of the hypocone usually occupied by a large, rather clear region, which does not take stains. Length ca. $25-40 \mu$.

Sands at Port Erin, Isle of Man. (C. Herdman.)

\section{Amphidinium semilunatum C. Herdman (1923).}

Text-figure $9 \mathrm{~b}$.

Body flattened from side to side; length about 1.4 dorso-ventral 
transdiameters and 3.5 lateral transdiameters. Hypocone sac-shaped, the ventral surface convex, while the dorsal surface is almost flat. Epicone low but conical, with broadly rounded apex; deeper on the left side than on the right. Its greatest depth is on the ventral surface, and is 0.3 of the total body-length. The ends of the girdle meet in the mid-ventral region without displacement: it is highest in the right dorsal region. Sulcus deep, extending from the girdle round the antapex to the dorsal side, and causing a notch in the antapex. Longitudinal flagellum arising close to the junction of the sulcus with the girdle. The nucleus is situated in the postero-ventral region. The cytoplasm is colourless and of glassy transparency; usually contains numerous coloured food masses. Length ca. $50 \mu$.

Occurred several times, but never in great numbers, on the beach at Port Erin. (C. Herdman.)

\section{Amphidinium manannini C. Herdman (1924).}

Text-figure 80.

Body broadly ellipsoidal. Epicone broad and low, slightly notched at the apex by the sulcus, which is rather deep and extends almost to the antapex. Protoplasm colourless and hyaline. Nucleus posterior. Another colourless refractile body lies in the mid-ventral region. Length ca. $20 \mu$.

In sand at Port Erin, Isle of Man. (C. Herdman.)

\section{Amphidinium vitreum C. Herdman (1924).}

Text-figure $8 \mathrm{~m}$.

Very thin and slender. Epicone small and rather flattened. Hypocone sac-shaped. Girdle higher on the left shoulder than on the right. Sulcus extending from the girdle to the antapex, very deeply impressed. Protoplasm clear and colourless. An elongated refractile body near the dorsal surface. Nucleus probably just ventral to this. Length ca. $20 \mu$.

In sand at Port Erin, Isle of Man. (C. Herdman.)

\section{Genus Gymnodinium Stein (emended by Kofoid and Swezy, 1921).}

Body without twist. Girdle may be a complete circle round the body or a descending left spiral displaced less than a fifth the total length of the body; usually near the centre, further back than in Amphidinium. Sulcus may extend from apex to antapex or may be very short on either epicone or hypocone, or both. Nucleus usually central or posterior. Pusules may be present, and may be fused. No nematocysts, no ocelli. Plasma colourless with or without chromatophores, or coloured. Pigment 
granules sometimes present. Surface smooth, striate, ridged or furrowed ; sometimes differentiated into an outer layer, the ectoplasm, and an inner layer, the endoplasm. The pellicle is usually very thin, so thin that it vanishes directly the cell collapses. Sometimes it may be thicker. Woloszynska (1917), Pascher (1923) and others have described freshwater forms which they relegate to this genus which have a distinct polygonal pattern over the sheath and the girdle clearly marked. None of these have been seen by the writer, but the marine forms are, so far, not known to possess such coverings. Encystment in thin-walled membrane frequent.

Marine, brackish and fresh water. Pelagic and littoral, mainly in temperate waters.

Kofoid and Swezy divide the genus into three sub-genera according to the surface structure or thickened pellicle:-(1) Gymnodinium proper, with the surface free from markings, or these, if present, few and scattered.

(2) Lineadinium, with thin pellicle and parallel striae on its surface.

(3) Pachydinium, with thickened pellicle having an outer layer with a knobbed structure.

The genus is here divided into three groups corresponding with these sub-genera :-(1) With smooth pellicle, (2) with striated thin pellicle and (3) with thickened pellicle which is knobbed.

Species:-1. With smooth pellicle.

Gymnodinium lunula Schütt, G. simplex (Lohmann), G. minor Lebour, G. pygmaeum n.sp., G. grammaticum Pouchet, G. marinum Saville Kent, G. agile Kofoid and Swezy, G. placidum C. Herdman, G. variabile C. Herdman, G. incertum C. Herdman, G. glandula C. Herdman, G. rubrocinctum n.sp., G. filum Lebour, G. splendens, n.sp., G. conicum Kofoid and Swezy, G. Lebourii Pavillard, G. pseudonoctituca Pouchet, G. minutum nom. nov., G. arcticum Wulff, G. pellucidum Wulff.

2. With striated thin pellicle.

G. rhomboides Schütt, G. heterostriatum Kofoid and Swezy, G. hyalinum n.sp., G. achromaticum Lebour.

3. With thickened pellicle.

G. abbreviatum Kofoid and Swezy, G. gracile Bergh.

Uncertain species.

G. Wilczeki Pouchet, G. pyrocystis Jörgensen, G. Lohmanni Paulsen, G. punctatum Pouchet, G. tintinnicula Lohmann, G. triangularis Lebour, G. vestificii Schütt. 


\section{With Smooth Pellicle}

\section{Gymnodinium lunula Schütt (1895).}

Plate IV, figures $1 \mathrm{a}-1 \mathrm{~g}$.

Kofoid and Swezy, 1921, p. 229.

Paulsen, 1908; Nordisches Plankton, pp. 110-111.

This species, referred by Kofoid and Swezy to the present genus, is one of the most important, as we know very nearly its complete life history. The crescents and spheres which constitute its various stages are well known practically all over the world. The free-swimming form is small with broadly ellipsoidal body, circular in cross-section, tapering slightly or rounded at the apices. Epicone and hypocone sub-equal; epicone a rounded cone, with convex sides and rather broad apex. Hypocone usually slightly more hemispherical than the epicone, with broader antapex. Girdle sub-median, slightly displaced, lefthanded; furrow deeply impressed. Sulcus extends on to the epicone and runs down to the antapex as a deep furrow. Anterior pore at the anterior junction of girdle and sulcus; posterior pore slightly behind the posterior junction. Nucleus posterior or nearly central. Plasma clear, greenish yellow. No pusules have been observed. Length ca. $22 \mu$.

There is a gap in the known life history of this species between the free-swimming form and the formation of a large spherical cyst, with a diameter $80-155 \mu$ (the smaller cysts from the English Channel). Inside the cyst the single individual divides into $2,4,8$ or 16 , so quickly that one can observe the division up to 8 within an hour, and each of these products of division becomes enclosed in a crescent-shaped cyst, 104-130 $\mu$ long. There are always 8 of these in the Plymouth specimens enclosed in the spherical cyst, and these break out and are found free in the water; the contents dividing into 2, 4, 6 or 8 individuals, each of which has the typical form of the free-swimming G. lunula. These emerge from the cyst and swim away. This individual may divide in a motile condition or in a small cyst. The formation of the large cyst, and how the free-swimming form is connected with it, have not been observed.

It is probable that most of the species of Gymnodinium have similar life histories, cyst formation in many forms being known. The Plymouth form may be a different species from that described by Kofoid and Swezy, as the dimensions differ. They are, however, so much alike that one does not feel justified in separating them without more exact data. Perhaps several species are confused. Neritic, cosmopolitan. 


\section{Gymnodinium simplex (Lohmann).}

Plate IV, figure 2. Text-figure 10 .

Protodinium simplex Lohmann, 1908.

Gymnodinium simplex Kofoid and Swezy, 1921, p. 256.

This minute species, found in numbers by Lohmann at Kiel, was discovered by Dr. Allen in a culture at Plymouth, October 22, 1918. With it were the diatoms Nitzschia closterium and Thalassiosira sp. Lohmann described it without a sulcus and girdle, but it was assumed to have these by Kofoid and Swezy, who placed it in the genus Gymnodinium. These authors are quite right, as a girdle, sulcus and both flagella were seen in the Plymouth examples, which were very small, ranging from $1 \cdot 7 \mu-7 \mu$. In the culture the smallest forms were minute roundish masses with four
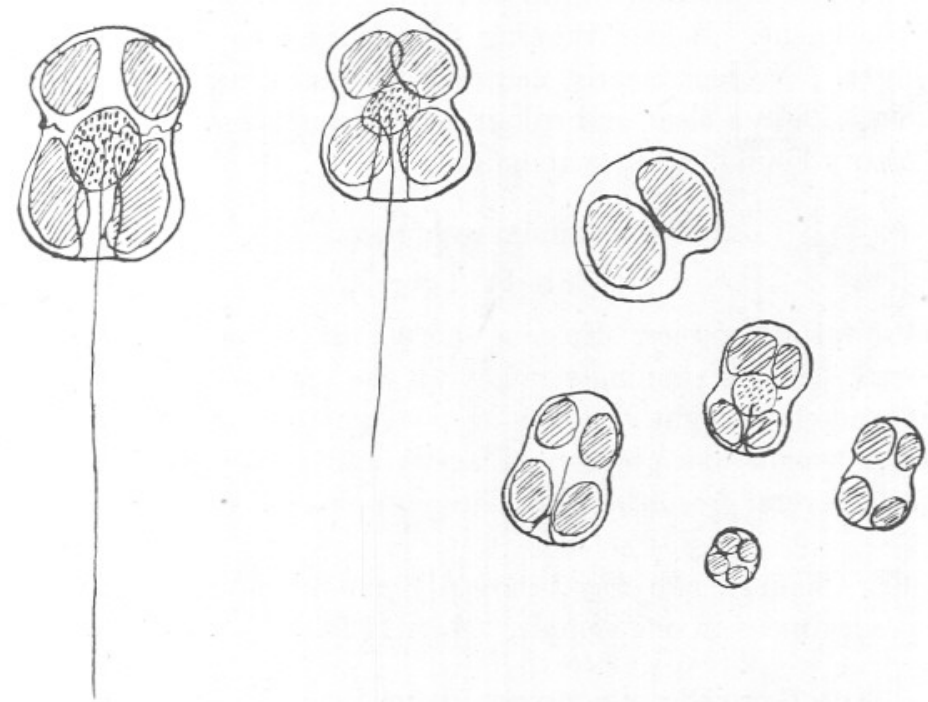

FIG. 10. Gymnodinium simplex (Lohmann).

Various stages, $1 \cdot 7$ to $7 \mu$. From culture in sea water, Plymouth.

yellowish green chromatophores and a central nucleus, without visible grooves and flagella. As these grew larger the transverse groove was plainly visible, then the sulcus and flagella. The largest may be described thus :- Cell oblong with wide girdle, not deeply impressed and not displaced. Epicone shorter than hypocone, rounded, conical; transverse flagellum completely encircling the girdle and very active; anterior flagellar pore at the junction of girdle and sulcus. Sulcus invading the epicone as a straight narrow groove running up for about half the length, widening posteriorly and notching the hypocone slightly. Hypocone 
rounded. Posterior flagellar pore just below the anterior pore. Longitudinal flagellum two to three times the cell length. Section of cell almost circular. Nucleus central. Four (or more ?) large greenish yellow chromatophores occupying most of the cell. Active movements forwards in a jerky spiral. Length $1 \cdot 7-20 \mu$.

Kiel ; Plymouth, in culture of sea water from Plymouth Sound.

\section{Gymnodinium minor Lebour (1917).}

Plate IV, figure 3.

Kofoid and Swezy, 1921, p. 233.

Cell roundish oval, the widest part anterior. Epicone larger than hypocone, sub-hemispherical, asymmetrical. Hypocone slightly narrower than the epicone with a truncated antapex. Girdle post-median, the furrow deeply impressed, contracted on the right, giving an appearance of displacement. Sulcus running from girdle to antapex, widening posteriorly. Nucleus nearly central. Greenish food masses present. Holozoic. Plasma clear and colourless. Length $28 \mu$.

Plymouth Sound. Never abundant.

\section{Gymnodinium pygmaeum n.sp.}

Plate IV, figure 4.

Minute rotund species. Epicone shorter than hypocone. Girdle wide, impressed. Sulcus running straight up the epicone and over the apex so as to notch it slightly, widening posteriorly, overlapped on the left side by a tongue-like process. Flagella and pores not seen. Nucleus anterior. Several greenish yellow chromatophores. Holophytic. Length $14 \mu$.

English Channel, half-way between Plymouth and the French coast. Several specimens in one sample. May, 1923.

\section{Gymnodinium grammaticum Pouchet (1883).}

Text-figure 11a.

Kofoid and Swezy, 1921, p. 217.

A minute roundish species, its length and transdiameter sub-equal, somewhat asymmetrical, rounded anteriorly. Epicone and hypocone sub-equal. Epicone hemispherical, hypocone rounded, with the antapex broadly notched by the sulcus, the right side slightly longer than the left. Girdle sub-median, not displaced. Sulcus not well defined in Pouchet's figures. Interior of body filled with small spherules. Plasma yellow, with a large red pigment spot from girdle to antapex. Nucleus not noted. Length $25-26 \mu$.

Concarneau, Brittany coast, Gulf of Naples. 
Gymnodinium marinum Saville Kent (1880-82).

Text-figure $11 b$.

Kofoid and Swezy, 1921, p. 232.

A minute species with broadly oval body, in ventral view with broad apex and antapex, widest posteriorly, compressed dorso-ventrally, lateral view kidney-shaped with convex dorsal and concave ventral surface. Hypocone longer and broader than epicone. Epicone hemispherical with symmetrically rounded sides. Hypocone hemispherical posteriorly. Girdle slightly premedian, not displaced, deeply impressed. Sulcus extends from girdle to antapex in a straight line. Longitudinal flagellum arises from the anterior end of the sulcus. Nucleus not described. Plasma
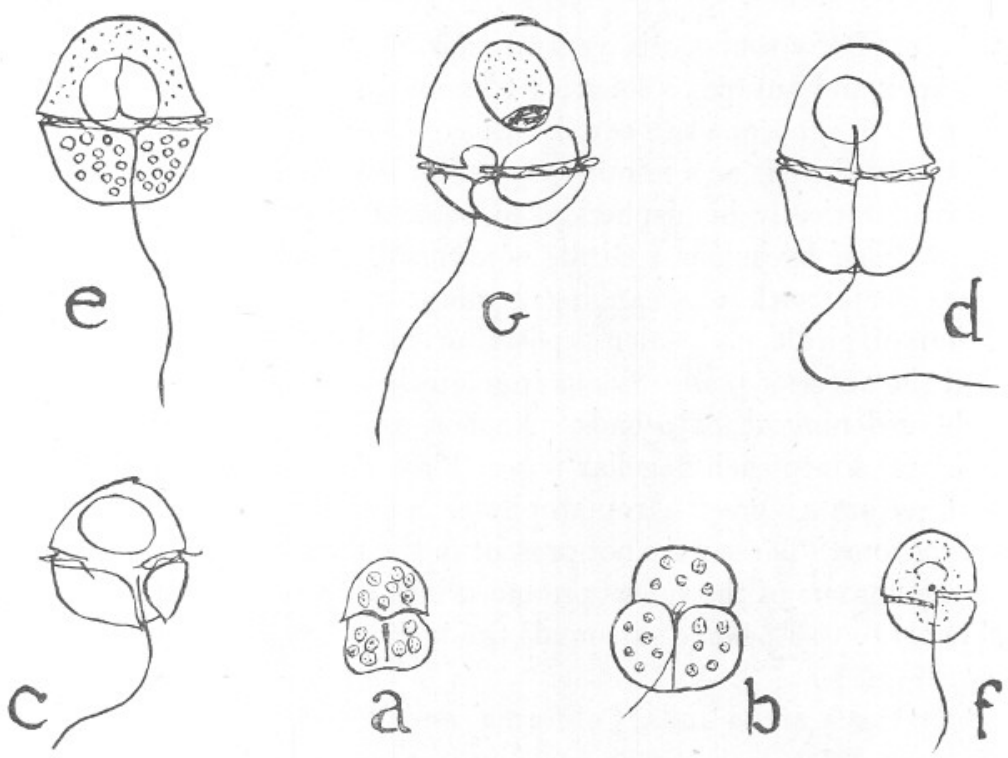

FIG. 11.

a. Gymnodinium grammaticum Pouchet. $25 \mu$ long, Brittany coast. After Pouchet, 1883.

b. Gymnodinium marinum Saville Kent.

$30 \mu$ long, from culture in sea water. After Saville Kent, 1880-82.

c. Gymnodinium agile Kofoid and Swezy. ca. $28 \mu$ long, Port Erin, Isle of Man. After C. Herdman.

d. Gymnodinium placidum C. Herdman. $50 \mu$ long, Port Erin, Isle of Man. After C. Herdman, 1922.

e. Gymnodinium variabile C. Herdman. ca. $40 \mu$ long, Port Erin, Isle of Man. After C. Herdman, 1924.

f. Gymnodinium incertum C. Herdman. ca. $15 \mu$ long, sand at Port Erin, Isle of Man. After C. Herdman, 1924.

g. Gymnodinium glandula C. Herdman. ca. $35 \mu$ long, sand at Port Erin, Isle of Man. After C. Herdman, 1924. 
clear and transparent containing numerous spherules. Holozoic. Observed by Saville Kent to devour Heteromita and other monads in the culture, the organism being taken in at the sulcal region near the girdle. Length $30 \mu$.

Found by Saville Kent in cultures made from an infusion of hay in sea water from St. Helier, Jersey.

Saville Kent considered Ehrenberg's Peridinium monas (G. monas Kofoid and Swezy, p. 235) as possibly identical with this form.

Gymnodinium agile Kofoid and Swezy (1921).

Text-figure 11c.

Kofoid and Swezy, 1921, pp. 184-185.

Minute. Body rounded in ventral view, flattened dorso-ventrally with broad apex and antapex; length 1.07 transdiameters at the widest part. Epicone and hypocone sub-equal. Epicone sub-hemispherical with apex displaced to the left as a minute projection bending downwards. Hypocone symmetrically hemispherical in ventral view, with antapex sometimes notched by sulcus. Girdle equatorial, not displaced, with broad furrow, deep, with overhanging borders. Anterior flagellar pore at junction of girdle and sulcus, posterior pore about 1.5 girdle widths behind the anterior pore. Sulcus from girdle to apex, a rather deep, wide trough, widening at both ends. Nucleus anterior. Sac-like bright red pusule opens into each flagellar pore. Plasma clear and colourless, with a few large orange-green chromatophores in the periphery of both epicone and hypocone. These were not present in the Port Erin specimens, which have the borders of the sulcus produced into ridges or spines. A distinct double-contoured pellicle surrounds the body. Length $15-30 \mu$. A sandloving form.

Sandy beach at La Jolla, California, and Port Erin, Isle of Man.

Gymnodinium placidum C. Herdman (1922).

Text-figure 11d.

Body ellipsoidal, dorso-ventrally flattened; length 1.5 transdiameters, and dorso-ventral diameter about half its transdiameter. Ventral surface more flattened than dorsal. Epicone slightly longer than hypocone, tapering anteriorly and expanding slightly posteriorly so as to form a thickened anterior rim to the girdle. Hypocone hemispherical. Girdle very slightly displaced; transverse flagellum completely encircling the body. Sulcus extending from about half-way between the apex and girdle to the antapex, the left border overlapping the right. Longitudinal flagellum projecting about the length of the body beyond the antapex. 
Nucleus in centre of epicone. Plasma full of small refractive bodies, and having a longitudinally streaked appearance. Movements slow and deliberate. Yellowish brown. Length $50-60 \mu$. A small example was also found which is presumably this species, with yellow-brown chromatophores. Length ca. $32 \mu$.

Sands at Port Erin, Isle of Man. Fairly common.

Gymnodinium variabile C. Herdman (1924).

Text-figure 11e.

Under this name Miss Herdman brings together a dozen or so small forms all nearly circular in ventral view and more or less flattened dorsoventrally. Girdle approximately equatorial, with little or no displacement. Sulcus varies from a shallow groove reaching from the girdle halfway to the antapex, to a well-marked furrow extending to the antapex and with a forward extension on to the epicone. Spherical nucleus roughly central. One, two or three orange or reddish bodies usually lie in the region of the sulcus. Protoplasm usually colourless or pale yellow, with or without colourless or greenish brown granules. Length from 8-40 $\mu$. As Miss Herdman suggests, some of these may be spores of some other dinoflagellate or may represent different stages in a single lifehistory.

In sand at Port Erin. (C. Herdman.)

Gymnodinium incertum C. Herdman (1924).

Text-figure 11f.

A small form somewhat flattened dorso-ventrally. Epicone hemispherical in ventral view, larger than the hypocone, which is rather more flattened than the epicone and considerably shorter. Girdle with its ends displaced about $0 \cdot 2$ of the total body length. Sulcus short, not extending on to the epicone nor reaching the antapex. Protoplasm colourless, with several rather large very pale green chromatophores. Nucleus central (?). A small reddish body lies near the proximal end of the girdle. Length $15 \mu$.

In sand at Port Erin, Isle of Man. (C. Herdman.)

Gymnodinium glandula C. Herdman (1924).

$$
\text { Text-figure 11g. }
$$

Body ovoid and flattened, somewhat asymmetrical. Epicone helmetshaped, with the apex produced into a sharp point which is bent backwards so as to lie closely along the surface. Girdle post-median, deeply impressed, its ends meeting without displacement. Hypocone only half 
the height of the epicone and not quite so wide. Sulcus extending forward a short distance on to the epicone (possibly not in all the larger specimens). On the hypocone it runs posteriorly and obliquely to the left. Longitudinal flagellum nearly twice the length of the body. Nucleus spherical and situated in the middle of the body. Protoplasm colourless, with pale greenish highly refractile granules. In larger specimens a red body is often present in the epicone and, in one, a large yellow body to which the red body is attached. Length $20-35 \mu$.

Sand at Port Erin, Isle of Man. (C. Herdman.)

\section{Gymnodinium rubrocinctum n.sp. \\ Plate IV, figure 5.}

Cell oval. Epicone more rounded than hypocone. Girdle equatorial, slightly impressed, displaced about one girdle width. Transverse flagellum short. Sulcus extending up the epicone for about threequarters of its length, slightly curved to the left, joining girdle where the anterior pore is situated ; then running straight down the hypocone widening as it goes, posteriorly enclosing a triangular knob, and slightly notching the hypocone. Posterior flagellar pore and flagellum not seen. Small pusule opens into the anterior pore. Nucleus round, central, dorsal, with a broad margin and large chromatin masses in strands. Plasma colourless except for a row of bright red granules below the girdle running round the dorsal and lateral part of the body. Length $52-56 \mu$.

Plymouth Sound, June, 1923. A few specimens.

The nucleus is similar to G. rubrum Kofoid and Swezy, the only other species in the genus with a differentiated outer nuclear layer.

Gymnodinium filum Lebour (1917).

Plate IV, figure 6.

Kofoid and Swezy, 1921, p. 207.

Body slender with biconical body, the length more than four times the transdiameter, tapering to a thread-like antapex. Dorso-ventral diameter slightly less than the transdiameter. Hypocone much longer than the epicone, the latter conical with narrow blunt apex. Girdle far anterior forming a complete circle round the body without displacement. Furrow deeply impressed. Sulcus begins about midway between the apex and girdle and continues as a straight line to within a short distance of the antapex. Flagella and pores not seen. Nucleus behind the centre. Holozoic, with solid food remains. Surface smooth. Plasma clear and colourless. Length $50-65 \mu$.

Plymouth Sound. Rare. 


\title{
Gymnodinium splendens n.sp.
}

\author{
Plate V, figure 1.
}

Cell oval, flattened dorso-ventrally, convex dorsally, flat or concave ventrally. Epicone and hypocone nearly equal. Girdle slightly impressed, displaced about a girdle width, anterior pore at the junction of sulcus and girdle. Sulcus not extending on to epicone, expanding posteriorly and deeply notching the antapex. Posterior pore about two girdle widths behind the anterior pore. Longitudinal flagellum longer than the body. Transverse flagellum nearly encircling the girdle. Nucleus sub-central, slightly anterior. Large elongated bright yellow chromatophores radiating from outside the centre to periphery, leaving the centre clear. Length $54-56 \mu$. Longitudinal oblique fission takes place.

Near the coast, Plymouth Sound, and also up the estuaries.

This species was recorded previously (1917) as Spirodinium fissum.

Gymnodinium conicum Kofoid and Swezy (1921).

Plate V, figure 2.

Kofoid and Swezy, 1921, p. 198.

Gymnodinium viridis Lebour, 1917.

Body sub-oval, its length nearly twice its greatest breadth. Somewhat asymmetrical, conical anteriorly. Transverse and dorso-ventral diameters nearly equal. Epicone conical, with a broad, blunt apex and slightly concave sides. Hypocone much longer than epicone with sub-parallel sides in ventral view, rounded posteriorly. In lateral view the ventral side is nearly straight, the dorsal side convex. Antapex broad and rounded, with a deep trough ventrally. Girdle premedian, displaced about 1.5 girdle widths, furrow wide and deeply impressed. Sulcus from the left of the apex to the antapex lying in the hypocone at the base of a deep trough. The sides are widely deflected near the antapex. Flagella and pores not seen. Nucleus large, nearly central. Plasma with numerous small greenish yellow chromatophores. Length $60 \mu$.

Plymouth Sound. Once only, in June.

Gymnodinium Lebourii Pavillard (1921).

Plate V, figure 3.

Gymnodinium pseudonoctiluca Lebour, 1917.

G. fulgens Kofoid and Swezy, 1921, p. 209.

Body elongated, conical anteriorly, rounded posteriorly; length more than twice its breadth. Girdle far anterior, not displaced, shallow. Epicone conical, with a blunt apex deflected dorsally ; hypocone rounded at the antapex in ventral view, in lateral view asymmetrical with dorsal 
side rounded and ventral flattened. On each side of the sulcus the body is drawn out into a flap, the left somewhat wider than the right. Sulcus begins at the girdle and extends to the antapex, obscured in the middle by the flaps, which become widely deflected posteriorly. Nucleus in the centre of the hypocone. Numerous bright yellow chromatophores radiating into the plasma from within. Large masses, probably food, in the hypocone. Nutrition probably both holophytic and holozoic. Length $100 \mu$.

Plymouth Sound, one specimen only.

Pavillard (1921) first called attention to the fact that this was a new species and not referable to G. pseudonoctiluca Pouchet. He therefore gave it the name of $G$. Lebourii, a fact apparently overlooked by Kofoid and Swezy (1921), who, coming to the same conclusion, called it. G.fulgens.

\section{Gymnodinium pseudonoctiluca Pouchet (1885a).}

Text-figures $12 \mathrm{a}$ and $12 \mathrm{~b}$.

Paulsen, 1908; Nordisches Plankton, pp. 97-99.

Kofoid and Swezy, 1921, pp. 243-244.

Body long, sub-cylindrical, anterior end conical, posterior rounded. Epicone much shorter than hypocone, extending posteriorly on the ventral side in a slender point, sub-conical anteriorly. According to Pouchet, the whole epicone is contractile within the body. Hypocone long, cylindrical, or enlarged posteriorly. Girdle anterior, both ends
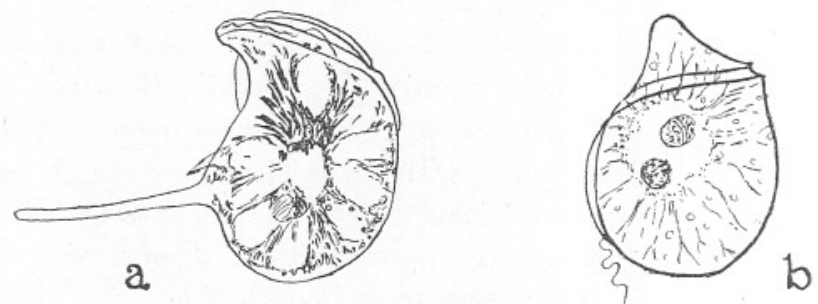

FIG. 12. Gymnodinium pseudonoctiluca Pouchet.

a. $200 \mu$ long, Brittany coast. After Pouchet, 1883 .

b. $200 \mu$ long, Gulf of Lions. After Pavillard.

turning posteriorly and meeting; furrow narrow and shallow. Sulcus, from girdle to apex. Nucleus large, nearly central, surrounded by a greenish mass composed of small bodies which radiate out into the protoplasm. These are said by Kofoid and Swezy, and also by Pavillard, not to be chromatophores. Pouchet calls them leucites and describes them as fusiform and of a greenish colour; this description was thought by the present writer to indicate chromatophores, as Pouchet's figures show 
much the same arrangement as was found in the Plymouth species attributed to G. pseudonoctiluca and now called Lebourii. A large tentacle may be protruded from the sulcal region. This is noticed again by Pavillard (1921) from the Gulf of Lions, who says these are not chromatophores but small uncoloured plastids. He describes the method of feeding on dinoflagellates (a truly holozoic nutrition), but apparently the tentacle is not used and remains of unknown function. He remarks that Protoceratium reticulatum is its usual food, but it also eats Diplopelta bomba and Peridinium divergens, both dinoflagellates of a large size. It divides longitudinally when its epicone disappears, whilst the hypocone greatly enlarges, becomes heart-shaped, and divides. Length $110-200 \mu$.

Brittany coast, Gulf of Lions, Faroes.

\section{Gymnodinium pyrocystis Jörgensen (1912).}

Kofoid and Swezy, 1921, p. 246.

Described by Jörgensen without a figure. Large species, with stout body. Epicone small, sub-conical, with apex blunt or truncate. Hypocone large, broadly rounded, often broader and thicker at the posterior end, truncate or notched with broadly round lobes. Girdle far anterior on dorsal side, both ends curving posteriorly ventrally. Sulcus extends from the region of the girdle to the antapex or passes around towards the dorsal side. Nucleus central. Cytoplasm contains an irregular central mass from which strands pass outward to the periphery, where they join ; filled with numerous spherules of varying size. Length $50-200 \mu$.

North Sea, west coast of Norway.

Gymnodinium minutum nom. nov. Plate V, figure 4.

Amphidinium rotundatum Lohmann, 1908.

$\begin{array}{ccc}" & \text { Wulff, 1916. } \\ " & \quad & \text { Paulsen, 1908; Nordisches Plankton, } \\ & \text { pp. 95-96. }\end{array}$

This minute species has hitherto been described as an Amphidinium. At first sight its form is similar, but its outer pellicle is hardly apparent at all, and, what is more important, the longitudinal flagellum is carried trailing behind the shorter portion of the body, which must be regarded as the hypocone. I have therefore transferred it to the present genus, and propose for it the name of Gymnodinium minutum.

Body somewhat top-shaped. Epicone conical, nearly twice as long as the hypocone, which is broadly rounded and very short. Girdle broad, hardly displaced; transverse flagellum very long and much more apparent 
than the longitudinal flagellum, which is nearly twice as long as the body. Sulcus very inconspicuous. Yellow-green leaf-like chromatophores. Nucleus posterior or central. Length $12-14 \mu$.

Kiel, White Sea, Yealm estuary near Plymouth. Abundant where it occurs.

\section{Gymnodinium arcticum Wulff (1916).}

\section{Text-figure 13a.}

Minute species. Girdle equatorial, epicone conical, hypocone rounded. Sulcus not determined and only dorsal views given. Small bright yellow chromatophores and refractive bodies scattered throughout the cell. Length $20-25 \mu$.

Barents Sea.
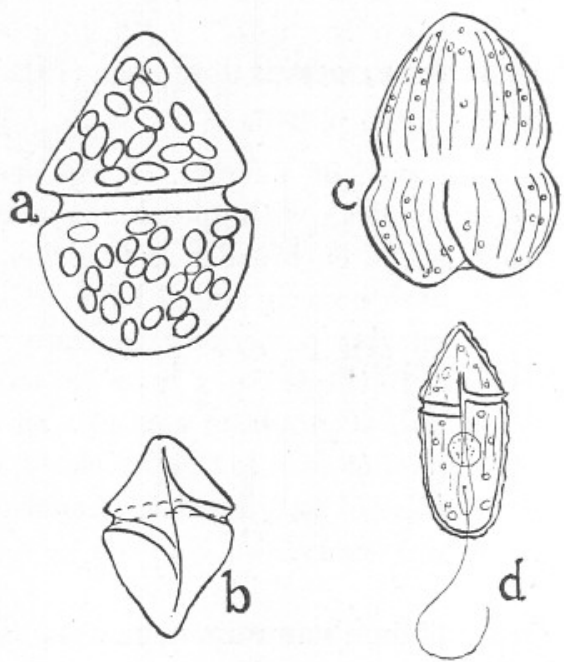

FIG. 13.

a. Gymnodinium arcticum Wulff.

$25 \mu$ long, Barents Sea. After Wulff, 1916.

b. Gymnodinium pellucidum Wulff.

$25 \mu$ long, Barents Sea. After Wulff, 1916.

c. Gymnodinium Wilczeki Pouchet.

$80 \mu$ long, Aretic Ocean, near Spitzbergen. After Pouchet, 1884.

d. Gymnodinium gracile Bergh.

$90 \mu$ long, Cattegat. After Bergh, 1881.

\section{Gymnodinium pellucidum Wulff (1916).}

Text-figure 13b.

Minute species. Ovate, pointed at both ends with slightly rounded epicone. Girdle displaced about two widths. Sulcus running up the epicone nearly to the apex and reaching posteriorly nearly to the antapex. No chromatophores, pellucid. Length $25-30 \mu$.

Barents Sea. 


\title{
2. With Striated Thin Pellicle
}

\section{Gymnodinium rhomboides Schütt (1895).}

\author{
Plate VI, figures 1a-1c.
}

Paulsen, 1908; Nordisches Plankton, pp. 97-99.

Kofoid and Swezy, 1921, pp. 249 and 250.

Body symmetrically biconical, widest in the middle. Epicone and hypocone both conical, with rounded apices. Hypocone rather longer than epicone. Girdle deeply impressed, displaced twice its own width or rather less. Sulcus runs up the epicone for a little more than half its length and extends nearly to the antapex. Anterior pore at the anterior junction of girdle and sulcus, posterior pore near the posterior end of the sulcus. Nucleus central or anterior. Cytoplasm colourless, with minute spherules or sometimes food masses. Surface ribbed on both epicone and hypocone, giving the girdle a scolloped appearance; fewer ribs on hypocone. Length $30-46 \mu$. Sometimes individuals are seen in thin oval cysts much larger than the cell itself.

Bay of Naples, Atlantic, Skaggerak, Plymouth Sound. Usually from near the shore and often very abundant in spring and summer.

\section{Gymnodinium heterostriatum Kofoid and Swezy (1921). Plate VI, figure 2.}

Kofoid-Swezy, 1921, p. 221.

A medium-sized species with symmetrical ellipsoidal body, its length 1.5 transdiameters; the apex and antapex may be broadly rounded or broadly pointed. Nearly circular in cross-section. Epicone and hypo. cone sub-equal typically, but in some of Dogiel's figures and in most of the Plymouth specimens the epicone is shorter than the hypocone. (As the other characters agree, it is thought best to keep the two forms together.) Epicone rounded or broadly conical. Hypocone sub-conical with rounded sides and a blunt apex. Girdle sub-median, displaced about its own width with a slight overlap. Furrow wide and deeply impressed. Sulcus narrow, extending from apex to antapex, fading away near the antapex. Anterior pore at the anterior junction of girdle and sulcus, posterior pore a short distance behind the posterior junction. Nucleus anterior. A small sac-like pusule is described by Kofoid and Swezy. Surface covered with longitudinal striae, fewer on the epicone than on the hypocone; between the striae the ends of a peripheral layer of rodlets may be seen. Kofoid and Swezy give the colour as generally a pale chalcedony yellow and pinkish cinnamon diffused through the cytoplasm. The Plymouth specimens were all colourless with much remains of food. Length $40-85 \mu$ from La Jolla, the smaller measurement from Plymouth. Often in hyaline cysts.

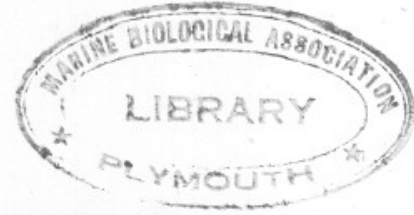


Bay of Naples, Plymouth Sound, La Jolla, California. Common, often close inshore.

In the author's paper (1917) the figures C and E of G. rhomboides represent this species. The true $G$. rhomboides must be closely related.

\section{Gymnodinium hyalinum n.sp.}

Plate VI, figures 3 and 4.

Medium sized, ovate. Length about 1.75 transdiameters. Epicone about half the length of hypocone, conical. Hypocone pointed or rounded. Girdle hardly displaced, impressed. Sulcus running up to the apex and sometimes just over it so as to notch it slightly, turning to the left, and reaching nearly to the antapex. Anterior flagellar pore at junction of sulcus and girdle; posterior pore half-way down hypocone. Nucleus subcentral. Surface striated, about 10 striae ventrally. Colourless and hyaline. Length $39 \mu$.

English Channel, off Polperro and Plymouth Sound.

Some specimens occurred with the sulcus widening posteriorly, slightly notching the antapex, and these had a broad square hypocone. Presumably, however, they belong to the same species (fig. 3).

Gymnodinium achromaticum Lebour (1917). Plate VI, figure 5 .

Kofoid and Swezy, 1921, p. 181.

A medium-sized species, body asymmetrical and broadly ellipsoidal; narrowing posteriorly. Epicone much shorter than hypocone, broadly conical; apex broadly rounded, excentric, situated ventrally and to the left. Hypocone long with sub-parallel sides in ventral view, tapering posteriorly in lateral view. Antapex broadly rounded and truncate, notched by sulcus. Girdle premedian, displaced about twice its width ; furrow wide, deeply excavated. Sulcus extending up the epicone for a short distance and to the antapex, narrow. Flagella and pores not seen. Body covered with longitudinal striae somewhat far apart. Pellucid and colourless. Nucleus posterior. Length $78 \mu$.

Plymouth Sound. One specimen only, July, 1915.

\section{With Thickened Pellicle}

Gymnodinium abbreviatum Kofoid and Swezy (1921).

Plate VI, figure 6.

Kofoid and Swezy, 1921, p. 180.

A medium-sized species with elongate ovoidal body, its length nearly twice the diameter, slightly asymmetrical, widest at the girdle. Epicone 
much shorter than hypocone, sub-conical, rounded at apex, which is slightly excentric. Hypocone long, with rounded antapex, slightly asymmetrical, notched by the sulcus, left side longer than right. Girdle premedian, displaced rather more than a quarter of the transdiameter; furrow fairly wide, not deeply excavated; anterior pore at anterior junction of girdle and sulcus; transverse flagellum not surrounding the body. Sulcus from apex to antapex, the left side on the epicone notched ; posterior flagellum at posterior junction of sulcus and girdle. Nucleus large, posterior. Pusules, according to Kofoid, may open into both pores, but were not seen by us. Surface of body mammillated and striated. Colour bluish pink, often with pink vacuoles. Remains of food often seen inside. In the figure a Cochlodinium has been eaten. Length 84-120 $\mu$.

La Jolla, California; mouth of English Channel(10 metres). Probably an oceanic species.

Gymnodinium gracile Bergh (1881).

Text-figure 13d.

Paulsen, 1908, p. 98.

Kofoid and Swezy, 1921, p. 98.

A large species with long sub-ovoidal or ellipsoidal body, its length slightly more than twice its breadth, circular in cross-section. Epicone short, dome-shaped, apex broadly rounded. Hypocone sub-cylindrical broadly rounded at the antapex, which is sometimes notched by the sulcus. Girdle premedian, displaced about twice its width. Sulcus begins somewhat below the apex and extends in a straight line to the antapex, lying in a trough, narrow anteriorly and widening posteriorly. Anterior pore at the anterior junction of girdle and sulcus, posterior pore midway between the posterior junction and antapex. Nucleus submedian or posterior. Small sac-like pusules usually present opening into both pores. Ectoplasm differentiated, but not into a distinct layer. Colour pale yellowish grey or pinkish, pink in Bergh's original specimen. Coloured food masses inside. Length $90-130 \mu$.

Baltic, Cattegat off the coasts of Denmark, Nova Scotia, La Jolla, California.

Var. exiguum Pouchet. A roundish form with girdle and sulcus incompletely shown. It is doubtful whether this is a Gymnodinium.

\section{UnCertain Species}

Gymnodinium Wilczeki Pouchet (1894).

Text-figure 13c.

Paulsen, 1908, p. 108.

Kofoid and Swezy, 1921, pp. 270-271.

A medium-sized species with ovoidal body deeply constricted by the E 
girdle; epicone slightly larger than hypocone. Both rounded, the hypocone notched by the sulcus. Girdle not fully shown, slightly postmedian. Sulcus extends from girdle to antapex forming a deep and wide excavation, making the hypocone appear bilobed. Surface marked by ridges. Green. Length $80 \mu$.

Arctic Ocean near Spitzbergen.

The following species are not sufficiently characterised, and are not figured :-

Gymnodinium Lohmanni Kofoid and Swezy (1921).

Kofoid and Swezy, 1921, p. 229.

Paulsen, 1908, pp. 99-100.

Is not sufficiently characterised, and we do not know with any certainty where to place it. It is a large species with reddish vacuoles, and stout rod-like bodies in the cytoplasm.

Found by Lohmann at Kiel.

Gymnodinium punctatum Pouchet (1887).

Paulsen, 1908, p. 108.

Kofoid and Swezy, 1921, p. 244.

A minute form not sufficiently characterised. Possibly a swarm-spore, as Paulsen suggests.

Gymnodinium tintinnicula Lohmann (1908).

Kofoid and Swezy, 1921, p. 261.

Found by Lohmann at Kiel emerging from a Tintinnid.

Probably a swarm-spore. Not sufficiently defined.

Gymnodinium triangularis Lebour (1917).

Kofoid and Swezy, 1921, p. 263.

A triangular species supposed by Kofoid and Swezy to be malformed. Not sufficiently defined.

Plymouth.

Gymnodinium vestifici Schütt (1895).

Paulsen, 1908, p. 97.

Kofoid and Swezy, 1921, p. 266.

This species is not sufficiently defined, but bears so strong a resemblance to Gyrodinium glaucum if turned upside down that one does not feel justified in regarding it as a Gymnodinium until the flagella have been described. 
Genus Gyrodinium Kofoid and Swezy (1921).

Spirodinium Paulsen, 1908; Nordisches Plankton.

Gymnodiniidae with girdle a descending left spiral displaced more than one-fifth of the total length of the body. Sulcus longitudinal or twisted, with a torsion of less than half a transdiameter in the region between the girdle ends (intercingular area); extending from apex to antapex, rarely curving round on the antapex beyond its posterior junction with the girdle, forming an antapical loop. Nucleus usually near the centre. Pusules may be present. No nematocysts. Surface striate or smooth; chromatophores rarely present. Nutrition often holozoic. Encystment in a thin-walled membrane frequent. Length $23-155 \mu$.

Marine and freshwater, littoral and oceanic. Arctic, temperate and tropical seas.

Kofoid and Swezy recognise two sub-genera, (1) without striations, Laevigella, and (2) with striations, Gyrodinium proper. These are kept here as two groups, with and without striations.

Species :-1. Without striations.

Gyrodinium falcatum Kofoid and Swezy, G. lingulifera n.sp., G. calyptoglyphe n.sp., G. prunus (Wulff), G. glaucum (Lebour), G. Lebourae C. Herdman.

2. With striations.

G. fissum (Levander), G. bepo (Schütt), G. britannia Kofoid and Swezy, G. spirale (Bergh), G. opimum (Schütt), G. obtusum (Schütt), G. pingue (Schütt), G. crassum (Pouchet), G. cochlea n.sp., G. cuneatum Kofoid and Swezy, G. lachryma (Meunier), G. grave (Meunier).

Uncertain species.

G. concentricum (Lebour), G. cornutum (Pouchet), G. fucorum (Küster), G. fusiforme Kofoid and Swezy, G.longum (Lohmann), G. ovatum (Gourret).

\section{Without Striations}

Gyrodinium falcatum Kofoid and Swezy (1921).

Plate VII, figure 1.

Kofoid and Swezy, 1921, p. 299.

Gymnodinium fusus Schütt, 1895, Pl. 25, fig. 81.

A large species with irregular spindle-shaped body, convex dorsally, nearly straight ventrally, its dorso-ventral and transdiameters sub-equal. Length ca. 2 transdiameters at the widest part or rather more. Epicone slightly larger than the hypocone; apex and antapex ending in a rounded 
point. Slightly asymmetrical. Girdle sub-median, displaced ca. $0 \cdot 4$ transdiameters or more; furrow deeply impressed. Sulcus running a short way up the epicone and down the hypocone. Flagella and pores not seen. Plasma full of stout rod-like yellow ochre chromatophores, closely crowded together. Nucleus central. Length 84-121 $\mu$. Plymouth specimen smallest. Schütt figured it in a cyst the same shape as the cell. The Plymouth specimen was without a cyst.

Schütt's species were obtained either from the Atlantic or Bay of Naples; English Channel from between the Eddystone Lighthouse and the Breakwater, Plymouth (7.12.21).

\section{Gyrodinium lingulifera n.sp. Plate VII, figure 2.}

A small species which seems to be allied to G. capsulatum Kofoid and Swezy, but quite colourless and smaller. Body rotund, length about equal to the breadth. Apices rounded, the apex rather less broad than the antapex. Epicone and hypocone sub-equal. Girdle sub-median, displaced $\frac{1}{4}$ of the transdiameter; the right end extended in a tongue-like process which slightly overlaps the sulcus, both epicone and hypocone helping to form the tongue. Sulcus not extending on to epicone, narrow at first, broadening behind into a wide furrow. Pores and flagella not seen. Colourless without striae. Nucleus oval, posterior. Food mass in the centre of the body. Length $39 \mu$.

Outside Plymouth Sound in open water.

\section{Gyrodinium calyptoglyphe n.sp.}

Plate VII, figures $3 \mathrm{a}$ and $3 \mathrm{~b}$.

Small, pellucid, colourless species, irregularly ovate; girdle making about 1.25 turns, deeply impressed, wide, displaced about two girdle widths. Sulcus running over the apex as a very thin groove, joining the girdle and the right margin, then overlapping at first in one small tonguelike process at the junction of sulcus and girdle, then in a large bilobed process in the intercingular area, and below the posterior end of the girdle is another tongue-like process. Thus the sulcus is hidden for most of its length, and finally ends in a broad antapical notch. Nucleus posterior. Plasma colourless, with refractive bodies and food remains. Flagella pores and flagella not seen. Length $28-30 \mu$.

Plymouth Sound, fairly common in summer.

\section{Gyrodinium prunus Wulff (1916).}

Text-figure 14a.

The shape of a plum. Epicone smaller than hypocone, both rounded, 
the hypocone more pointed. Girdle impressed, rather narrow, displaced ca. $\frac{3}{4}$ transdiameters. Sulcus straight, running a little way up the epicone and terminating near the antapex. Nucleus anterior. Cytoplasm smooth, several vacuoles and numerous refractive bodies. Many yellow-brown chromatophores. Length 40-50 $\mu$.

Barents Sea.
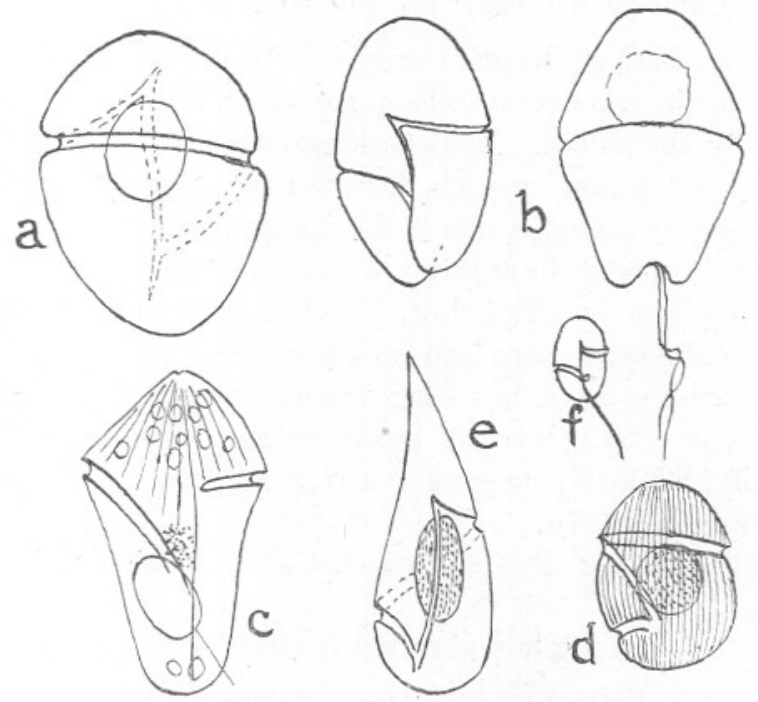

FIG. 14,

a. Gyrodinium prunus Wulfi.

(?) $40 \mu$ long, Barents Sea. After Wulff, 1916.

b. Gyrodinium fissum (Levander).

(?) $30 \mu$ long, Finnish coast. From Paulsen, 1908. After Levander.

c. Gyrodinium cuneatum Kofoid and Swezy.

$90 \mu$ long, coast of Brittany. From Kofoid and Swezy, 1921, after Pouchet.

d. Gyrodinium grave (Meunier).

$57 \mu$ long, Nova Zembla. After Meunier, 1910.

e. Gyrodinium lachryma (Meunier).

$105 \mu$ long, Kara Sea. After Meunier, 1910.

f. Gyrodinium Lebourae C. Herdman.

ca. $15 \mu$ long, sand at Port Erin, Isle of Man. After C. Herdman, 1924.

\section{Gyrodinium Lebourae C. Herdman (1924).}

Text-figure $14 \mathrm{f}$.

A small and very active form. - Body ellipsoidal, hardly flattened dorsoventrally. Girdle a descending left spiral, its ends displaced about onethird of the total body length. Sulcus extending to the antapex. A small red body lies near the posterior end of the girdle. Length ca. $15 \mu$.

Sand at Port Erin, Isle of Man. (C. Herdman.) 


\section{With Striations}

Gyrodinium fissum (Levander) (1894).

Text-figure $14 \mathrm{~b}$.

Paulsen, 1908; Nordisches Plankton, pp. 101-102.

Kofoid and Swezy, 1921, pp. 300-301.

Body sub-ovoidal, its length nearly two transdiameters at the girdle. Nearly circular in transverse section, rounded at apex and antapex, the latter cleft by the sulcus. Epicone longer than hypocone. Girdle displaced about $0 \cdot 3$ transdiameters, furrow narrow and deeply impressed. Sulcus begins near the right side of the apex and extends to the antapex. Anterior flagella pore at the anterior junction of girdle and sulcus, posterior pore about one girdle width below. Nucleus near the centre, sometimes anterior. Small pusule opens into each pore, but may be absent. Plasma coarsely granular with a few long greenish rodlets radially arranged. Peripheral zone with a layer of much smaller rodlets. Surface striate longitudinally. Colour pale green; a tinge of coral occurs rarely in the epicone. Length $30-57 \mu$.

La Jolla, California; Brittany coast, Gulf of Finland, Aral Sea.

Gyrodinium glaucum (Lebour) (1917).

Plate VII, figure 4. Text-figure 15.

Kofoid and Swezy, 1921, pp. 308-309.

Spirodinium glaucum Lebour, 1917.

Body broadly spindle-shaped, tapering at both ends. Length about 2.5 transdiameters. Nearly circular in cross-section. Widest about the centre, girdle very far back. Epicone occupying most of the body. Apex pointed, sometimes slightly twisted. Hypocone short, pointed. Antapex excentric, notched by sulcus. Girdle very broad, deeply impressed, displaced about three to four girdle widths. Sulcus running a short way up the apex, widening into a wedge-shaped furrow posteriorly. (This does not agree with Kofoid and Swezy, who describe it as narrow near the antapex.) Anterior pore at the anterior junction of sulcus and girdle, posterior pore at the posterior junction. Transverse flagellum runs right round the body. Longitudinal flagellum much longer than the body. Nucleus posterior to the centre, usually anterior to the girdle. Plasma clear and colourless, with a few greenish rodlets extending from the apex nearly to the girdle and sometimes in the hypocone. Usually a large bright yellow oval body in the extreme anterior end: this is probably some product of food formation, and not merely ingested food. Longitudinal striae indistinct. Length $40-56 \mu$. Division in the free state frequently 
seen (text-figure 15). Kofoid and Swezy's solitary specimen referred to this species differs in colour, in the sulcus being narrow posteriorly and the nucleus anterior, occupying the exact position of the yellow oval body in the Plymouth form. It is possibly a different but closely related species, the girdle being unusually far back in both.

Plymouth Sound and outside - one of the commonest species ; La Jolla, California (?).
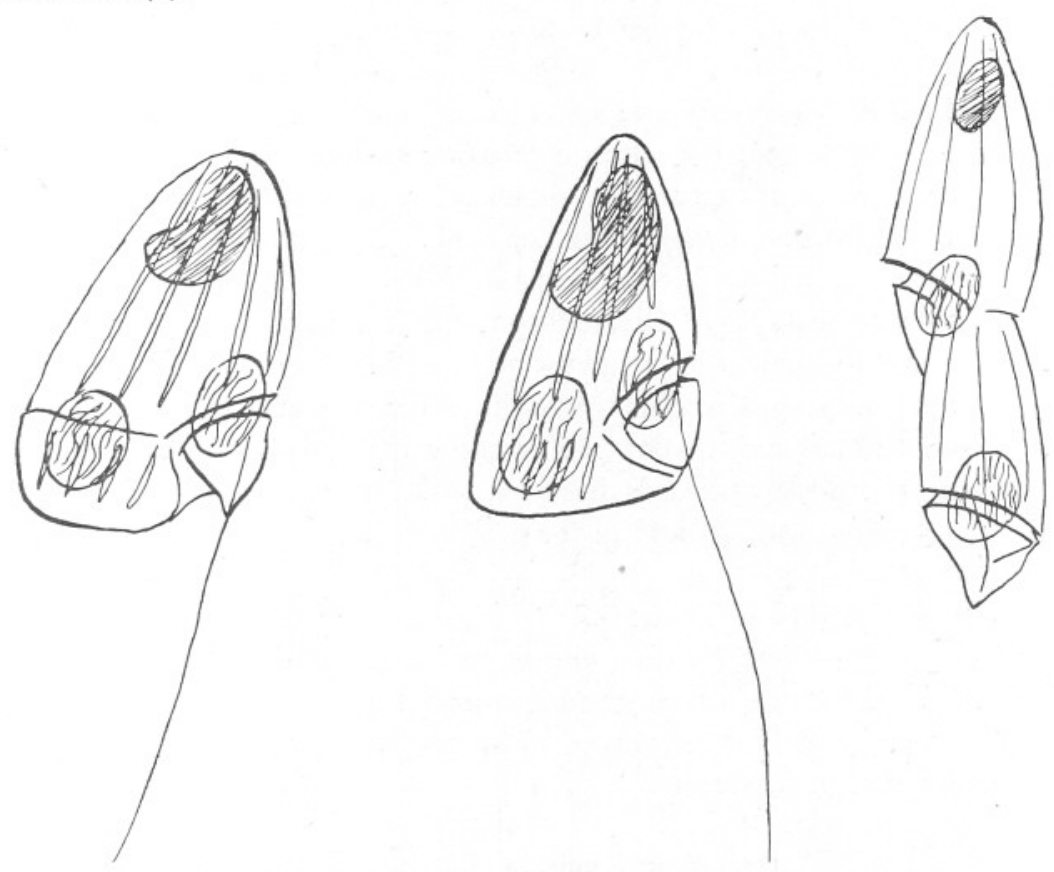

FIG. 15. Gyrodinium glaucum (Lebour), 1917.

Dividing; Plymouth Sound.

Gyrodinium bepo (Schütt) (1895).

Plate VII, figure 5.

Kofoid and Swezy, 1921, pp. 326-327.

Gymnodinium spirale var. bepo (Schütt), 1895.

Body flask-shaped with curved apex ; length about $1 \frac{1}{2}$ transdiameters, greatest width at the middle of the hypocone. Wide roundly pointed epicone. Girdle displaced about 0.5 transdiameters. Sulcus straight from apex (or near it) to antapex. Anterior flagellar pore at junction of girdle and sulcus, posterior pore slightly below. Nucleus anterior. Plasma colourless, in Schütt's specimens filled with large vacuoles. Length $56-84 \mu$. 
Atlantic or Bay of Naples (?) (Schütt), Plymouth Sound, not very common.

Gyrodinium britannia Kofoid and Swezy (1921). Plate VII, figure 6.

Kofoid and Swezy, 1921, p. 287.

Spirodinium spirale var. acuta Lebour, 1917.

This species was given specific rank by Kofoid and Swezy, mainly on account of its colour; it is, however, sometimes colourless. Having found further specimens and on making further careful examinations, the conclusion is that it is truly a separate species. Cell large with long spindle-shaped body, its length about $3 \cdot 3$ transdiameters, widest in the middle. Hypocone longer than epicone. Epicone sub-conical, with slightly convex sides and blunt apex. Hypocone more slender with a more pointed antapex. Girdle beginning far anteriorly, is displaced nearly 1.5 transdiameters; furrow wide and deeply impressed. Sulcus from apex to antapex, slightly twisted. Nucleus nearly central. Pellicle with longitudinal striae, about 15 on the ventral face; brilliant carmine granules in bead-like threads followed these striae, congregating chiefly at the apex and antapex and in the neighbourhood of the girdle. Length $140-168 \mu$.

Plymouth Sound and outside.

This species differs from G. spirale in its larger size; less girdle displacement, the girdle also beginning nearer the anterior end; less twist of the sulcus and blunter apices. The red colour is also characteristic and not found in G. spirale.

\section{Gyrodinium spirale (Bergh) (1881). Plate VIII, figure 1.}

Kofoid and Swezy, 1921, pp. 232-233.

Gymnodinium spirale Bergh, 1881.

Spirodinium nasutum Wulff, 1916.

Spirodinium maximum Wulff, 1916.

This is the most widely distributed species and the type of the genus. Cell variable, spindle-shaped, with spiral sulcus ; length of body 2.5 transdiameters; nearly circular in section, widest posteriorly. Dorsal side convex, ventral sub-concave, the whole body slightly asymmetrical. Epicone rather larger than hypocone, conical, convex on left and dorsally, concave on right and ventrally. Apex blunt. Sides of hypocone subparallel anteriorly, rounded posteriorly, deeply notched on the left side of the antapex by the sulcus. Girdle a steep descending spiral, displaced nearly two transdiameters; furrow deeply impressed. Sulcus from apex 
to antapex with a torsion of nearly $0 \cdot 2$ transdiameters, narrow anteriorly, widening somewhat posteriorly. Anterior flagellar pore at the anterior junction of girdle and sulcus, posterior pore about one girdle width below. Nucleus antero-central. Small sac-like pusules which may be united open into the pores, or may be absent. Plasma finely granular, clear and transparent in the Plymouth specimens. Kofoid and Swezy describe it as pale glaucous green to ivory yellow. About 15 surface striae across the ventral face. Length $40-150 \mu$. (Plymouth specimens $40-98 \mu$.)

World wide. La Jolla, California; Australia, Indian Ocean, Adriatic, Mediterranean, Baltic, Norway; Port Erin, Isle of Man; Plymouth Sound and outside.

\section{Gyrodinium opimum (Schütt) (1895). \\ Plate VIII, figure 2.}

Gyrodinium contortum Kofoid and Swezy, 1921 (in part), p. 291. Gymnodinium opimum Schütt, 1895 (fig. 686).

A species very like Schütt's figure of G. opimum occurs in Plymouth Sound, but smaller. These are, however, not at all like G. contortum with which Kofoid and Swezy have joined the above species of Schütt. I have therefore separated them again. Cell asymmetrically ovoid, curving at the apex to the left with a bluntly conical epicone. Girdle forming a spiral displaced about three-quarters of the transdiameter; furrow wide, deeply impressed. Sulcus strongly deflected to the left, having a twist of about 0.5 transdiameters, running from apex to antapex in a thin line not widening posteriorly. Nucleus central. No rodlets perceptible in the plasma, which is colourless and transparent. One pusule usually present opening into the posterior pore at the posterior junction of girdle and sulcus. Length $50 \mu$ from Plymouth, $111 \mu$ in Schütt's specimens.

Atlantic or Bay of Naples (?) (Schütt), Plymouth Sound. Not very common.

\section{Gyrodinium obtusum (Schütt) (1895). Plate VIII, figure 3.}

Kofoid and Swezy, 1921, pp. 319-320.

Gymnodinium spirale var. obtusa Schütt, 1895.

Cell symmetrically ellipsoidal with broad rounded apices, widest in the middle, its length 1.75 transdiameters. Cross-section nearly circular. Epicone usually less broad than hypocone and smaller. Girdle forms a steep descending spiral displaced about one transdiameter; furrow rather broad, deeply impressed. Sulcus from apex to antapex in a nearly straight narrow line, widening at the apex. Anterior flagellar pore at anterior junction of girdle and sulcus, posterior pore about one width of the girdle 
below the posterior junction. Nucleus central or postero-central. Saclike pusules opening into each pore may be connected or may be absent. Surface striae broken or complete. A peripheral zone of short rodlets sometimes present. Colour amber-yellow. Length 50-70 $\mu$. Plymouth specimens the smallest.

La Jolla, California; Bay of Naples or Atlantic (?) (Schütt), Plymouth Sound.

$$
\begin{aligned}
& \text { Gyrodinium pingue (Schütt) (1895). } \\
& \text { Plate VIII, figure } 4 .
\end{aligned}
$$

Kofoid and Swezy, 1921, p. 327.

Gymnodinium spirale var. pinguis Schütt, 1895.

(?) Spirodinium varians Wulff, 1916.

(?) S. Schütti Wulff, 1916.

Body elongated ovoidal, circular in cross-section, rounded or roundly pointed posteriorly and anteriorly; length nearly two transdiameters. Girdle displaced $0 \cdot 74$ transdiameters; furrow deeply impressed. Sulcus from near the apex to the antapex in a slightly sinuous line, rather shallow, fading out near the antapex. Nucleus anterior or nearly central. Sac-like pusule may be present opening into one pore, or one at each pore. Plasma often dense with many inclusions; peripheral layer of rodlets sometimes present. Surface striae close together or far apart. Length $45-60 \mu$.

La Jolla, California; Barents Sea, Bay of Naples or Atlantic (?) (Schütt), Plymouth Sound.

\section{Gyrodinium crassum (Pouchet) (1885a). \\ Plate VIII, figure 5.}

Kofoid and Swezy, 1921, pp. 294-295.

Spirodinium crassum Paulsen, 1908; Nordisches Plankton, pp. $102-$ 103.

Cell large, with long ellipsoidal body, its length 2.54 transdiameters ; apices irregularly rounded, the epicone more pointed, the hypocone bluntly rounded and slightly notched by the sulcus. Girdle displaced 0.92 transdiameters, or rather less; furrow narrow. Sulcus runs a short way up the epicone and continues as an almost straight line to the antapex as a narrow groove. Pores not seen. Longitudinal flagellum not quite so long as the body. Surface striae inconspicuous, wide apart. Plasma filled with large round bodies. Colour a diffuse brown concentrated in masses at the apex and in the girdle region. Length $75-200 \mu$. Plymouth specimens small.

Arctic Ocean near Spitzbergen, Mediterranean, coast of Brittany, Plymouth Sound. 


\section{Gyrodinium cochlea n.sp.}

Plate VIII, figure 6.

Allied to $G$. spirale but with a twisted sulcus invading the apex and forming an apical loop. Cell long, oval with broad flat epicone and pointed hypocone. Girdle beginning very far forward making about 1.25 turns, displaced one transdiameter. Sulcus beginning on the left of the epicone behind the apex, twisting round and making about 0.75 turns before joining the girdle, then sweeping round for about $0 \cdot 25$ turns and running down beyond its posterior junction with the girdle in a straight line. Anterior flagellar pore hidden by the right sulcal margin, but apparently at the anterior junction of girdle and sulcus; posterior pore at the posterior junction. Plasma hyaline and colourless, surface striae following the line of twist of the sulcus. Colourless rods and masses of fat inside the cell. Nucleus behind the centre. Length $55 \mu$.

Plymouth Sound. Fairly frequent in summer.

\section{Gyrodinium cuneatum Kofoid and Swezy (1921).}

Text-figure 14c.

Kofoid and Swezy, 1921, p. 297.

Gymnodinium gracile Pouchet, 1885.

A large species with sub-ovate or wedge-shaped body; length 1.72 transdiameters, widest at the girdle. Hypocone nearly twice the length of the epicone. Epicone a broad low cone with the apex slightly notched, and drawn out on the right into a long slender point. Hypocone rounded posteriorly. Girdle premedian for most of its length, displaced about 0.6 transdiameters; furrow deeply impressed. Sulcus probably running from the apical notch to the hind end, where it becomes an obscure trough. Longitudinal flagellum arises a short distance behind the posterior junction of girdle and sulcus. Epicone striated. Nucleus postcentral. Central part of plasma full of yellow-orange granules; general colour a transparent rose. Length $90-100 \mu$.

Coast of Brittany.

Gyrodinium grave (Meunier) (1910).

Text-figure $14 \mathrm{~d}$.

Kofoid and Swezy, 1921, pp. 309-310.

Spirodinium grave (Meunier) 1910.

Cell stout, ellipsoidal ; length about 1.30 transdiameters; epicone and hypocone sub-equal, epicone sub-hemispherical, hypocone broadly rounded. Girdle displaced about $0 \cdot 6$ transdiameters, forming a descend- 
ing spiral, wide, deeply impressed. Sulcus as figured runs between the girdle ends, but is probably longer. Flagella not figured. Nucleus central. Surface covered with longitudinal striations, about 30 on the ventral face. Length $57 \mu$.

Arctic Ocean, near Nova Zembla.

The next species is not well defined :-

Gyrodinium lachryma (Meunier) (1910).

Text-figure 14e.

Kofoid and Swezy, 1921, p. 314.

Spirodinium lachryma Meunier, 1910.

Cell ovoid, broadly rounded posteriorly, gradually tapering to a point anteriorly; length $2 \cdot 83$ transdiameters. Girdle forms a spiral displaced $1 \cdot 4$ transdiameters; furrow narrow, shallow. No flagella figured. Sulcus from anterior end of girdle to antapex. Nucleus central. Peripheral zone of plasma filled with small rodlets. Colour unknown. No striations. Length $105 \mu$.

Arctic, Kara Sea, Nova Zembla.

The following are not properly known and not figured here :-

Gyrodinium concentricum (Lebour), 1917.

Kofoid and Swezy, 1921, p. 290.

Spirodinium concentricum Lebour, 1917.

This, as Kofoid and Swezy suggest, was probably parasitised by Amoebophrya (see above, pp. 8, 9). It is therefore no longer regarded as a valid species.

\section{Gyrodinium cornutum (Pouchet) (1883).}

Kofoid and Swezy, 1921, p. 293.

Not characterised sufficiently to warrant its being recognised as a species.

Gyrodinium fucorum (Küster) (1908).

Kofoid and Swezy, 1921, p. 305.

Not characterised sufficiently.

Gyrodinium fusiforme Kofoid and Swezy (1921).

Kofoid and Swezy, 1921, p. 307.

Spirodinium fusus Meunier, 1910.

From the Arctic. Not characterised sufficiently. 
Gyrodinium longum (Lohmann) (1908).

Kofoid and Swezy, 1921, p. 314.

Kiel. Not sufficiently characterised.

Gyrodinium ovatum (Gourret) (1883).

Kofoid and Swezy, 1921, p. 322.

Not sufficiently characterised.

\section{Genus Cochlodinium Schütt (1895).}

Gymnodiniidae, with twist of the body of at least 1.5 turns. Girdle a descending left spiral of 1.5 or more turns, widely displaced. Sulcus with or without apical and antapical loops, and with a twist of 0.5 or more turns. Nucleus usual central or posterior. Pusules usually present, opening into the flagellar pores, often united. No nematocysts. Plasma colourless to highly coloured. Usually holozoic. Pigment granules sometimes present. Surface usually smooth, rarely striated. Encystment in thin-walled membrane frequent. Rarely a tendency to colonial formation. All known species are marine from temperate seas. The number of northern forms being so small, the sub-genera suggested by Kocoid and Swezy are omitted.

Species:-Cochlodinium Schuetti Kofoid and Swezy, C. helicoides nom. nov., C. helix (Pouchet), C. pupa n.sp., C. vinctum Kofoid and Swezy, C. achromatioum n.sp., C. Archimedes (Pouchet), C. pulchellum Lebour, C. Brandti Wulff.

Cochlodinium Schuetti Kofoid and Swezy (1921).

Plate IX, figure 1.

Kofoid and Swezy, 1921, p. 380.

Gymnodinium helix Schütt (in part) 1895. Plate XXIV, fig. 77 (6).

Body a rounded oval; length about 1.5 transdiameters. Girdle a descending left spiral of 1.5 turns, displaced about 0.52 transdiameters; furrow deep. Epicone more rounded than hypocone; sulcus may invade the epicone in a curve for a short way, with twist of 0.5 turns ; deeply constricted in the centre with a shallow sulcal notch. Pusules sometimes present. Plasma yellow, with greenish droplets scattered all over the celi. Nucleus postero-central or central. Usually enclosed in a thinwalled cyst loosely covering the cell. Length $52-74 \mu$.

Atlantic or Bay of Naples (Schütt), La Jolla, California; Plymouth Sound. Never common. 


\section{Cochlodinium helicoides nom. nov.}

Plate IX, figure 2.

Cochlodinium helix Schütt, 1895. Plate XXII, fig. 77 (5).

Kofoid and Swezy, 1922, pp. 370 and 371.

Kofoid and Swezy have divided the Cochlodinium helix figured by Schütt into two, one of which they name Cochlodinium Schuetti, the other retaining Pouchet's original name of Cochlodinium helix. There is, however, another species in the English Channel which is almost certainly the species described by Pouchet as Gymnodinium helix (1887), and which agrees with Schütt's figures 77 (1-4). Schütt's figure 77 (5) agrees with Kofoid and Swezy's C. helix, which also occurs in the Channel, and the third, C. Schuetti, is also to be found there. Another name must therefore be given to the $C$. helix of Kofoid and Swezy, and this I have called $C$. helicoides. It differs from the original $C$. helix in the coils of both girdle and sulcus which do not extend so far, and particularly in the absence of the outstanding posterior process, over which runs the girdle and which is the special feature of $G$. helix. Cell sub-oval asymmetric; length about 1.4 transdiameters ; left side drawn out into a process which does not project on the right, so that no appearance of uncoiling is shown. Girdle making 1.5 turns, displaced about 0.65 transdiameters, deeply impressed. Sulcus invades the epicone and may partly encircle the apex, joins the girdle and below it turns about 0.6 times. Flagellar pores at the anterior and posterior junctions of girdle and sulcus. Antapex slightly notched. Nucleus central. Pusules sometimes present. Colour yellow; usually with chromatophores. Sometimes enclosed in a thin hyaline cyst. Length $36-54 \mu$.

Atlantic or Bay of Naples (?) (Schütt), La Jolla, California; Plymouth Sound. Never common.

Cochlodinium helix (Pouchet) (1887).

Plate IX, figures 3a-3c.

Paulsen, 1908; Nordisches Plankton, pp. 103-104 (in part).

Schütt, 1895. Plate XXII, figure $77(1-4)$.

Cell distinctly coiled, the outline oval, with both girdle and sulcus much impressed. Transverse section round. Epicone round to subconical. Girdle beginning far anteriorly and making two turns, the last part running round a posterior process which is part of the hypocone and looks like part of the coil uncurled. The girdle is displaced about one transdiameter. Sulcus narrower than girdle, invading the epicone in a slight curve, and joining the girdle where the anterior flagellar pore is situated, then sweeping round, making one complete turn from its anterior 
junction with the girdle, and, joining the girdle posteriorly, runs straight down to the antapex. Posterior flagellar pore at the posterior junction of girdle and sulcus. Nucleus central. Colour yellow, diffuse or in masses. Flagella rarely seen, both short. Sometimes contained in a thinwalled case, tight or loose. Length $32-45 \mu$.

Brittany coast, Atlantic or Bay of Naples (?) (Schütt), Plymouth Sound. Never common.

\section{Cochlodinium pupa n.sp. \\ Plate IX, figures $4 a-4 c$.}

A perfectly pellucid and colourless species, allied to $C$. clarissimum Kofoid and Swezy, but more barrel-shaped and with fewer sulcal turns. Epicone and hypocone flattened. Girdle making 1.75 turns, deeply impressed. Sulcus running half-way up the epicone, joining the girdle and then making 0.75 turns, ending in a posterior depression slightly notching the antapex. Nucleus posterior. Flagella and pores not seen. Refractive colourless bodies in plasma. Length $39 \mu$.

Outside Plymouth Sound, one specimen only, July.

Cochlodinium vinctum Kofoid and Swezy (1921).

Plate IX, figures 5a-5b.

Kofoid and Swezy, 1921, p. 384.

Body a roundish oval, irregular, arched dorsally. Length 1.4 transdiameters. Girdle a descending spiral of 1.5-1.65 turns, displaced about 0.6 of the total length, deeply impressed. Sulcus invading the epicone in an apical loop which may completely encircle the apex or merely form a curve, joining the girdle and curving round the body making $0.5-0 \cdot 6$ turns, meeting the girdle again and turning posteriorly in a widening trough which sometimes slightly notches the apex. Anterior flagellar pore at the anterior junction of girdle and sulcus, posterior pore at posterior junction. Clear and colourless or pale bluish ; Plymouth specimens colourless. Small refractive bodies scattered in plasma. Often large food inclusions, probably dinoflagellates. Pusules may be present. Length 42-75 $\mu$, smallest from Plymouth.

La Jolla, California ; outside Plymouth Sound, fairly frequent, singly, in summer.

\section{Cochlodinium achromaticum n.sp.}

Plate IX, figure 6.

This species is closely related to Kofoid and Swezy's two species, C. clarissimum and C. faurei, but it is smaller, with smaller anterior sulcal loop than C. clarissimum, whilst the sulcus below the loop curves much more to the right than in $C$. faurei, so that a tongue-like process 
hangs over the sulcus to the right below the junction of sulcus and girdle. Cell roundish oval ; length about 1.4 transdiameters. Girdle a descending spiral of two turns, displaced about 0.8 transdiameters, deeply impressed. Wide anterior flagellar pore at junction of girdle and sulcus, posterior pore at the posterior junction. Sulcus begins at the apex, making half a turn before joining the girdle, then making one complete turn notching the antapex. About half the width of the girdle, impressed. Nucleus posterior. No pusules seen ; flagella short. Food masses present. Plasma hyaline and colourless, with refractive globules irregularly scattered. Length $43 \mu$.

Outside Plymouth Sound. Rare. May.

\section{Cochlodinium Archimedes (Pouchet) (1883).}

Text-figure $16 \mathrm{a}$.

Paulsen, 1908 ; Nordisches Plankton, p. 103.

Kofoid and Swezy, 1921, p. 351.

Body ellipsoidal, asymmetrical; length 2.05 transdiameters. Girdle a descending spiral of 2.5 turns, deeply impressed. Sulcus following the course of the girdle for 1.5 turns, shallow. Nucleus anterior: Near the
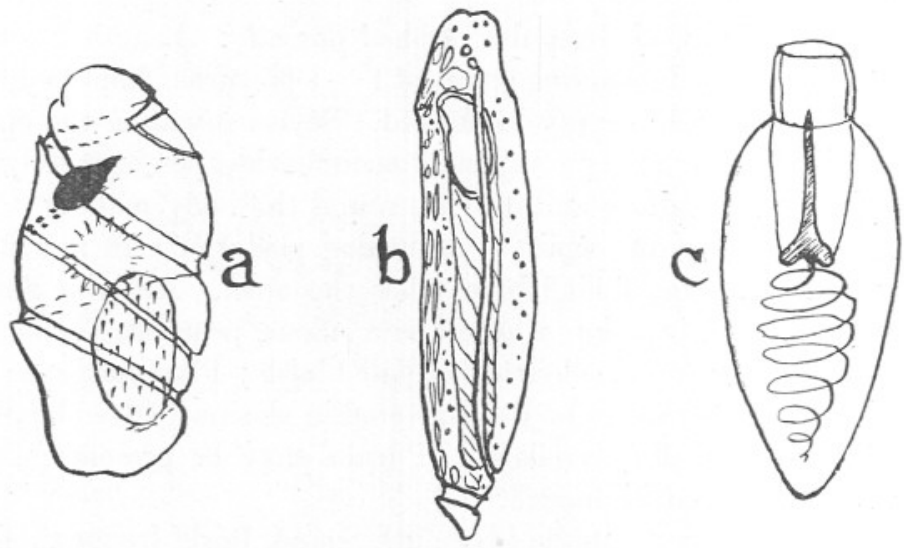

FIG. 16.

a. Cochlodinium Archimedes (Pouchet).

$75 \mu$ long, Brittany coast. After Pouchet, 1883 ; emended by Kofoid and Swezy.

b. Torodinium teredo (Pouchet).

(?) $100 \mu$ long. From Kofoid and Swezy, after Schütt.

c. Nematocyst of Polykrikos Schwarzi.

$19 \mu$ long, Plymouth Sound. 
centre of the body is a sphere formed by short rodlets, radially arranged. Anteriorly is a large red pigment mass, possibly food remains. Length $75 \mu$. Brittany coast.

Cochlodinium pulchellum Lebour (1917).

Plate IX, figure 7.

Kofoid and Swezy, 1921, p. 376.

This species, which was incorrectly drawn in the first description, is accurately described by Kofoid and Swezy. Body asymmetrically spindle-shaped, deeply constricted by girdle and sulcus; length nearly 3 transdiameters. Girdle making just over 3 turns, displaced 0.76 of the total length. Sulcus running up the epicone for a short distance, making 2.5 turns below its junction with the girdle. Flagella not seen. Nucleus posterior. Colourless in the Plymouth specimens, clear and hyaline, pale green or blue according to Kofoid and Swezy. Enclosed in a loose thin structureless cyst. Length $35-50 \mu$.

English Channel, Plymouth; La Jolla, California. Very rare.

Cochlodinium Brandti Wulff (1916).

Plate IX, figure 8.

Cochlodinium augustum Kofoid and Swezy, 1921, p. 354.

This species was discovered by Wulft in the Barents Sea. It is so similar to C. augustum that there seems little doubt that they are identical. One specimen was found at Plymouth which is smaller than either the Barents Sea form or those from California. Wulff gives two figures measuring $98 \mu$ and $67 \mu$ respectively, so there is a wide range in size. Body spindle shaped with rounded ends; length rather more than twice the breadth. Girdle making 4 turns or just over 4, displaced about 0.75 of the total length, deeply impressed; anterior flagella pore at the anterior junction of sulcus and girdle. Sulcus running a short way up the epicone, making 3 turns or just over 3 , deeply impressed, but much narrower than the girdle. Posterior flagellar pore at the posterior junction of sulcus and girdle. Flagella short. Club-shaped pusule opening into each pore. Nucleus central or posterior. Clear hyaline, colourless in the Plymouth specimen; in the Californian form a mixture of grey, blue, green or pink. Length 56-108 $\mu$; smallest from Plymouth.

La Jolla, California; Barents Sea; outside Plymouth.

\section{Genus Torodinium Kofoid and Swezy (1921).}

Body elongate. Epicone several times the length of the hypocone. Hypocone conical. Girdle forming a descending left spiral, slightly dis- 
placed. Sulcus with a very long apical loop with a twist of about 0.5 turns posteriorly, straight anteriorly; running most of the length of the body, nearly to the apex. Nucleus very long. Linear, longitudinal yellow masses (chromatophores or rod-like bodies known as rhabdosomes) on the left side and usually massed in a star near the apex.

Species :-Torodinium robustum Kofoid and Swezy, T. teredo (Pouchet).

Torodinium robustum Kofoid and Swezy (1921).

Plate X, figure 1.

Kofoid and Swezy, 1921, p. 391.

Gymnodinium teredo Paulsen, 1908; Nordisches Plankton, p. 97 (in part).

Elongated shaped body: length of body $2 \cdot 8-3 \cdot 2$ transdiameters. Epicone $0.83-0.85$ of the total length. Hypocone minute. Girdle a descending left spiral, displaced about twice the width of its furrow, deeply impressed. Sulcus runs almost from apex to antapex, with a twist of about 0.4 turns; it twists at the apex for about 0.75 turns, running dorsally, and finally joining the girdle ventrally on the right side. Nucleus very long. Long pusule opening into the anterior flagellar pore. On the left are four rows of yellow bodies, sometimes continuous, sometimes separate, their function not known. Anteriorly is a yellow star of these same bodies radiating from a centre. Large bodies, probably remains of food, are found inside, and nutrition is probably holozoic. Length $36-75 \mu$.

La Jolla, California; Atlantic or Bay of Naples (?) (Schütt), Plymouth Sound. Common.

Torodinium teredo (Pouchet) (1885).

Text-figure $16 \mathrm{~b}$.

Kofoid and Swezy, 1921, p. 393.

Gymnodinium teredo Paulsen, 1908; Nordisches Plankton, pp. 97-98 (in part).

Body very elongate; length $4 \cdot 3-5$ transdiameters. Epicone forms $0 \cdot 88-0.91$ of the total length. Girdle forms a descending left spiral without overlap, displaced less than 1.5 furrow's width. Sulcus with twist of 0.5 turns near the girdle and runs up straight nearly to the apex without a loop. Length $100-113 \mu$.

Atlantic, Pacific and Indian Oceans, Mediterranean, Brittany coast.

The specimens formerly recorded from Plymouth (1917) were probably all $T$. robustum. 
Family POLYKRIKIDAE Kofoid and Swezy (emended).

Gymnodinioidae with a permanent colonial organisation, 2, 4 or 8 individuals (zooids) in chains, each having a Gymnodinium type of structure. Girdle a descending left spiral of one turn. Sulcus extending from apex to antapex. Plasma coloured or colourless, without pigment. Nematocysts present or absent. Marine, neritic, from warm and temperate waters.

\section{Genus Polykrikos Bütschli (1873).}

With the characters of the family. Number of nuclei usually less than that of the zooids, generally in a ratio of 1 to 2 , sometimes 1 to 4 . Surface of hypocone ribbed or smooth (smooth in the Northern forms). Holozoic nutrition usual. Colour greenish to rose. P. Lebourae has probably yellow chromatophores which apparently may be absent. Division by the formation of a new girdle between those already existing, followed by a division of the nuclei.

Widely distributed.

Species :-Polykrikos Schwarzi Bütschli, P. Lebourae C. Herdman.

Polykrikos Schwarzi Bütschli (1873).

Plate $\mathrm{X}$, figures $2 \mathrm{a}$ and $2 \mathrm{~b}$. Text-figure $16 \mathrm{c}$.

Paulsen, 1908; Nordisches Plankton, pp. 106-107.

Kofoid and Swezy, 1921, p. 400.

Colonial body composed of 2,4 or 8 zooids, or up to 16 when dividing; length about 0.44 transdiameters. Diameter from side to side rather longer than dorso-ventral. Girdle median, only very slightly displaced. Sulcus extending for the whole length of the body. Epicone nearly twice as wide as the hypocone. All the flagella feebly developed. Plasma usually pinkish, sometimes colourless, containing nematocysts, variable in number, usually about 6 or 8 and $10-20 \mu$ in length. Each nematocyst consists of a flask-shaped body with short neck containing a pointed dart with its point towards the neck connected at its base with a long coiled thread. When discharging, the dart is first thrown out and the thread, which is presumably hollow, follows, probably being everted like the inturned finger of a glove (Text-figure 16c). Four nuclei in the colony of eight zooids. Length of chain of eight zooids $100-140 \mu$.

La Jolla, California ; Arctic near Iceland, Skaggerak, Cattegat, Norway, Baltic, North Sea, Mediterranean, English Channel.

Fairly common in Plymouth Sound in summer. 
Polykrikos Lebourae C. Herdman (1924).

Plate X, figure 3.

Polykrikos Schwarzi C. Herdman, 1922.

Colony broadly ovate, consisting of eight zooids flattened laterally with a slight twist. Epicone and hypocone nearly equal. Body broadest in the middle. Girdle slightly displaced, longitudinal flagella long and conspicuous. Sulcus slightly notching the antapex and reaching the centre of the hypocone. Plasma colourless, usually with numerous yellow chromatophores, which appear to radiate outwards from the centre. Miss Herdman has also seen forms in which there appear only to be food masses. It may be that the chromatophores described here come from ingested food, but from the appearance they seem to belong to the organism itself. Possibly we have two methods of feeding in the same species. There are no nematocysts. Nuclei two. A sand-loving species, very much flattened laterally as an adaptation to its surroundings. Length $56 \mu$.

Found on the beach at Port Erin, Isle of Man, with other sand-loving dinoflagellates.

\section{Family NOCTILUCIDAE Saville Kent.}

Gymnodinioidae characterised by the presence of a tentacle, more or less mobile; without ocellus. The tentacle arises in the sulcal area and extends posteriorly. In Noctiluca this is obscured in the adult form, but is apparent in the small Gymnodinium-like stages. The genus Pavillardia Kofoid and Swezy only occurs in California, and the well-known Noctiluca is the only Northern representative of this family. It was only recently that the dinoflagellate affinities of Noctiluca were established by Kofoid (1919), although many suggestions of the kind have been made; even now its position here is not universally accepted.

\section{Genus Noctiluca Suriray.}

Body inflated, somewhat kidney-shaped to spheroidal. Distinction between epicone and hypocone obliterated in the adult by the loss of girdle resulting from the formation of large vacuoles. Sulcus very deep, the mouth region extended anteriorly in the depression known as the apical trough. Girdle probably represented only by a small ventral portion. Longitudinal flagellum short, transverse flagellum reduced to a projecting mobile membrane or tooth. Tentacle at posterior end of sulcus. Plasma much vacuolated, the strands of protoplasm running from the periphery to the central mass containing the nucleus ; colourless or bluish 
green, sometimes tinged with yellow in the centre. When many are stranded together on the shore they look pinkish. Multiple fission produces zoospores with girdle, one flagellum and tentacle. Diameter 200-2000 $\mu$. Neritic, marine, cosmopolitan.

One species :-Noctiluca scintillans Macartney.

Noctiluca scintillans Macartney (1836).

Text-figures $17 \mathrm{a}-17 \mathrm{~d}$.

Kofoid and Swezy, 1921, pp. 407-413.

With the characters of the genus. Well known for its large size and luminescent qualities. Abundant at times; world wide.
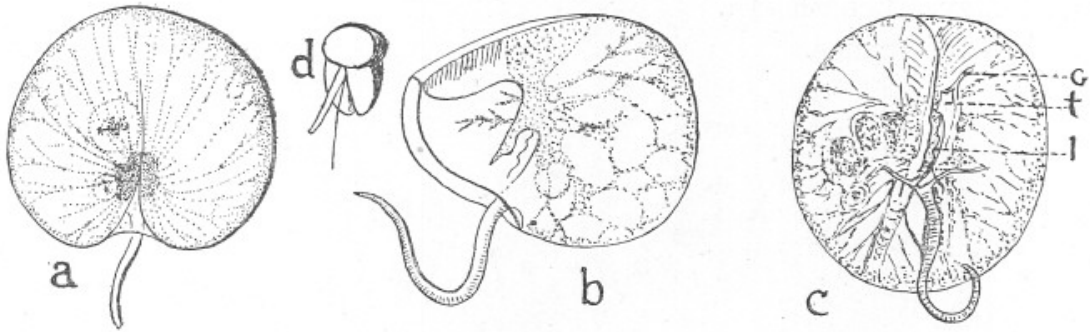

Frg. 17. Noctiluca scintillans Macartney.

a. Dorsal view, $350 \mu$ across, Plymouth. Drawing by Miss G. E. Webb.

b. Lateral view. From Kofoid and Swezy, after Allman.

c. Postero-lateral view. From Kofoid and Swezy, modified after Robin. $l$. =longitudinal flagellum. $g=$ girdle. $t=$ tranverse flagellum.

d. Zoospore. From Kofoid and Swezy, after Cienkowski.

Family POUCHETIIDAE Kofoid and Swezy.

Gymnodinioidae with ocellus on the left side of the intercingular sulcus, consisting of lens and pigment mass, melanosome. Epicone and hypocone sub-equal. Girdle and sulcus with more or less twist. Pusules usually present. Plasma usually coloured. Pelagic and marine.

Principally from warm temperate waters and tropical seas, rarely in purely neritic waters. Very few in the Northern area, the most highly developed of all, Erythropsis, being apparently absent.

\section{Genus Protopsis Kofoid and Swezy (1921).}

With girdle and sulcus like Gymnodinium or Gyrodinium. Simple or compound ocellus. No tentacle. No apical loop to the sulcus. No twist 
of the body. Girdle does not make more than one turn round the body. Posterior flagellar pore not far back. Pelagic and marine.

Species:-Protopsis nigra (Pouchet), P. simplex n.sp.

Protopsis nigra (Pouchet) (1887).

Text-figure 18a.

Kofoid and Swezy, 1921, pp. 418-420.

Body asymmetrically ovoid; length 1.5 transdiameters. Girdle equatorial, displaced $0 \cdot 3$ transdiameters. Sulcus straight, mid-ventral. Ocellus dispersed, with 5-8 spherical lenses, amoeboid black melanosome and red core. Plasma yellow ochre, with scattered black granules in periphery. Length $74 \mu$.

Coast of France.

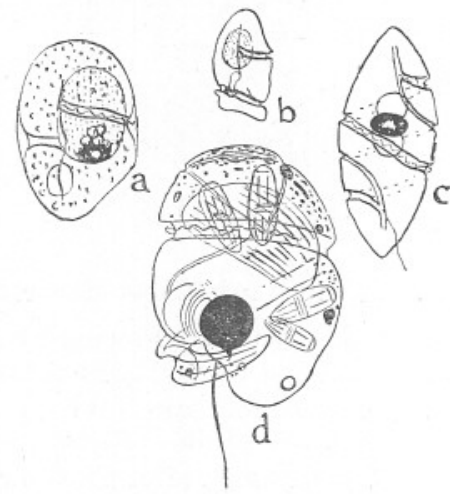

FIG. 18.

a. Protopsis nigra (Pouchet).

$74 \mu$ long, French coast. From Kofoid and Swezy, after Pouchet.

b. Pouchetia rosea (Pouchet).

(?) $44 \mu$ long, Brittany coast. From Kofoid and Swezy, after Pouchet.

c. Pouchetia fusus Schütt.

$94 \mu$ long. After Schütt, 1895, from Kofoid and Swezy.

d. Protoerythropsis vigilans Marshall.

ca. $58 \mu$ long, Millport on the Clyde. After K. Maxwell (from S, Marshall's paper, 1925).

\section{Protopsis simplex n.sp. \\ Plate $\mathrm{X}$, figure 4.}

This form closely resembles $P$. nigra, but has a simple lens and no black pigment. The girdle is displaced more. Body in shape and size like $P$. nigra. Girdle displaced about $0 \cdot 4$ transdiameters. Sulcus slightly curved, invading the epicone. Ocellus dispersed, black; simple spherical 
lens. Plasma yellow without pigment. Nucleus anterior. Enclosed in a loose cyst. Length $74 \mu$.

Plymouth Sound. Rare.

\section{Genus Nematodinium Kofoid and Swezy.}

With nematocysts. Girdle with more than one turn, displaced more than 0.5 transdiameters. Sulcus with twist of 0.75 turns or more, with a posterior turn on the dorsal side of the antapex. Ocellus dispersed or concentrated, located far posteriorly. Marine, pelagic, holozoic or possibly both holozoic and holophytic.

One species :-Nematodinium armatum (Dogiel).

\section{Nematodinium armatum (Dogiel) (1906).}

Plate $\mathrm{X}$, figures 5a and $5 \mathrm{~b}$.

Kofoid and Swezy, 1921, pp.422-442 (in part).

Kofoid and Swezy unite a larger species $(95-100 \mu)$ from California with Dogiel's Pouchetia armata from Naples, which is about half the size. There are also other differences, e.g. in the larger form, smoother outline due to the more shallow girdle and sulcus, smaller nematocysts in proportion to the body, and colour. These may justify the separation of the two. A species similar to Dogiel's is found fairly commonly in the neighbourhood of Plymouth. It is, however, smaller, usually measuring $28-44 \mu$, Dogiel's species being about $50 \mu$ long. This species and Dogiel's thus bear the name Nematodinium armatum, and the Californian form is very likely a distinct species. N. armatum may be described thus :-

Small species with girdle and sulcus deeply impressed ; length 1.5 transdiameters; ovoidal ; girdle a descending left spiral making 1.5 turns, displaced about $0 \cdot 75$ transdiameters. Sulcus extending on to epicone making 1.25 turns, joining the girdle posteriorly some way before the end of its course. Ocellus far back, black, simple; lens spherical. Nucleus anterior. Nematocysts about $14 \mu$ long, grouped usually in the neighbourhood of the nucleus. Yellow chromatophores or diffuse yellow plasma. Length $28-50 \mu$. Often in closely fitting cyst in which division takes place.

Naples, Plymouth and neighbourhood, (?) La Jolla, California.

\section{Genus Pouchetia Schütt (emended by Kofoid and Swezy, 1921).}

No posterior prod. Girdle a descending left spiral of 1·15-2 turns. Sulcus with a twist of $0 \cdot 25-1 \cdot 75$ turns of a descending left spiral, its apical loop with from $0-1.5$ turns, and its antapical loop sometimes attaining one turn. No paracingular lines (i.e. lines running parallel with 
the girdle). Ocellus with red or black pigment mass with red, brown, yellow or colourless core. Lens hyaline, laminate (i.e. in plate-like layers) or in segments. Nucleus usually anterior to ocellus. No nematocysts. Plasma generally highly coloured, scattered pigment granules, black or coloured, sometimes present. Holozoic nutrition. Encystment in thinwalled membrane frequent. Pelagic in warm and temperate seas.

Species :-Pouchetia fusus Schütt, P. polyphemus (Pouchet), P. parva Lohmann, P. rosea (Pouchet).

Pouchetia fusus Schütt (1895).

Text-figure 18c.

Kofoid and Swezy, 1921, pp. 443-444.

Body spindle-shaped ; length $2 \cdot 33$ transdiameters. Girdle a descending left spiral of two turns, displaced 1.33 transdiameters. Sulcus with one turn, without apical and antapical loops. Ocellus premedian, with lens of two parts and pigment mass encircling them equatorially. Length $94 \mu$.

Bay of Naples or Atlantic (?) (Schütt), Plymouth Sound.

Unfortunately, although this species occurred at Plymouth a few times, no drawing was secured.

Pouchetia polyphemus (Pouchet) (emended).

Plate X, figure 6.

Kofoid and Swezy, 1921, pp. 453-455.

Body elongated, ellipsoidal ; length $2 \cdot 2$ transdiameters. Girdle with two turns. Sulcus with 0.5 turns after its anterior junction with the girdle, and running on to the antapex, but not so far as in Kofoid and Swezy's emended drawing. Ocellus premedian, simple, with elongated hemispherical lens and large pigment mass. Plasma colourless. Length $75-104 \mu$.

Atlantic, Brittany coast, Iceland, outside Plymouth Sound (one specimen only, $75 \mu$ ).

Kofoid and Swezy have given a drawing of the supposed structure of this species. Our own specimen appears to agree with Pouchet's description and is not unlike the reconstruction of Kofoid and Swezy, but the sulcus is not so winding.

Pouchetia parva Lohmann (1908).

Paulsen, 1908; Nordisches Plankton, p. 106.

Kofoid and Swezy, 1921, pp. 451-453.

This minute species is not sufficiently described. Those previously recorded from Plymouth were afterwards found to be encysted Nemato- 
dinium armatum, which are sometimes very small with the nematocysts very indistinct. It is possible that this is the true interpretation of Lohmann's species.

Pouchetia rosea (Pouchet) (emended by Kofoid and Swezy). Text-figure $18 \mathrm{~b}$.

Paulsen, 1908; Nordisches Plankton, pp. 105-106.

Kofoid and Swezy, 1921, pp. 460-463.

A small species with irregularly ellipsoidal body; length $1 \cdot 3-1 \cdot 66$ transdiameters. Girdle a descending left spiral of at least 1.25 turns, displaced about 0.5 the total body length. Sulcus with less than 0.5 turns. Ocellus with elongated lens and red pigment mass. Length $44-58 \mu$.

Atlantic at Concarneau; Mediterranean at Cette.

\section{Genus Protoerythropsis Kofoid and Swezy, 1921.}

Like Pouchetia but with a posterior prod. Pigment granules inclined to a linear arrangement.

One Northern species:-Protoerythropsis vigilans Marshall.

\section{Protoerythropsis vigilans Marshall (1925).}

\section{Text-figure 18d.}

Small ovoidal body; length $1 \cdot 4$ times the greatest width. Girdle a descending left spiral of $1 \frac{1}{4}$ turns with a continuation on to the tentacle (prod). Sulcus describing nearly half a turn. Ocellus compact, posterior ; lens pear-shaped with concentric rings; red pigment mass with yellow core. Slender tentacular process (prod) carrying continuation of girdle. Elongated capsules present in the cell, each containing six smaller capsules. Pinkish red pigment. Large anterior nucleus. Transverse flagellum short, arising well behind girdle. Longitudinal flagellum long. Division almost transverse. Length $38-58 \mu$. Greatest breadth $30-44 \mu$.

Millport and elsewhere in the Clyde area.

This interesting form has been recently discovered by Miss S. Marshall. It is the nearest approach to Erythropsis so far discovered in our area.

\section{Family BLASTODINIIDAE Kofoid and Swezy (1921).}

This family includes all the parasitic forms which are described by Chatton (1920) in detail. These are found externally on animals and plants (on the tails of appendicularians and on the setae of diatoms); internally, in animals either in the alimentary canal or coelom; or in eggs, very often inside copepods and in their eggs.

As an example we may take one of the intestinal forms inhabiting 
copepods, which is the only one so far found at Plymouth-Blastodinium hyalinum Chatton (Text-figures 19a-19c). This species inhabits the alimentary canal of Calanoid Copepods, Clausocalanus, Paracalanus and Pseudocalanus. The large spindle-shaped mass occupies the alimentary canal and contains small spores (microspores) and large spores (macrospores). The microspores emerge as small naked dinoflagellates with typical transverse and longitudinal flagella. The specimens (spore cases in Pseudocalanus elongatus) from Plymouth measured $480 \mu$ in length.
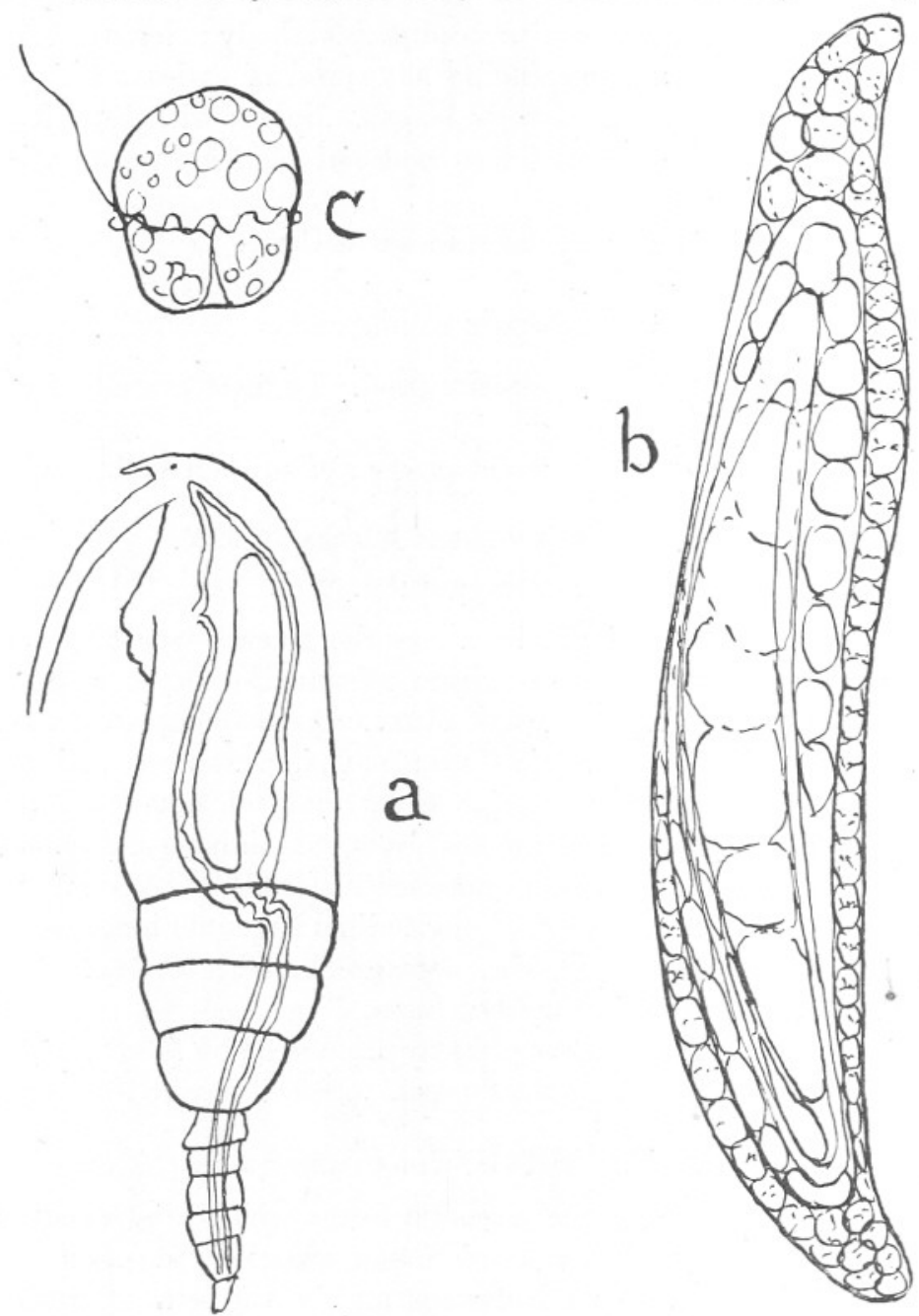

FIG. 19, Blastodinium hyalinum Chatton.

a. Spore case in Paracalanus parvus, $\times 150$. b. Resting stage dividing $\times 260$. c. Spore, $\times 1200$. After Chatton, 1920 . 
Tribe PERIDINIOIDAE Kofoid and Swezy.

Diniferidea with theca composed of more than two pieces, divided into epitheca, girdle and hypotheca; each of these may be divided into numerous plates. Variously shaped. Flagellar pore pierces the theca and the two flagella emerge from it.

\section{Family DINOPHYSIDAE Kofoid and Michener (1912).}

Body flattened laterally. Theca divided by a seam (or suture) into two lateral halves. Transverse furrow situated far forward. Epitheca small. Membranes attached to the girdle (transverse or girdle lists), usually conspicuous, often broad and directed forwards, in which case the front one is often funnel-shaped. Membranes of the longitudinal furrow (longitudinal lists) usually very broad and supported by spines. No apical pore (i.e. a pore piercing the apex of the epitheca). Theca usually provided with pores and poroids.

\section{Genus Pseudophalacroma Jörgensen (1923).}

Epitheca conspicuous. Sulcus prolonged on to epitheca up to about two-thirds the distance from girdle to apex, showing a dilated rounded end. Left longitudinal list very slightly developed and presumably destitute of ribs or spines.

Species :-Pseudophalacroma nasutum (Stein).

\section{Pseudophalacroma nasutum (Stein) (1883).}

Text-figures $20 \mathrm{a}$ and $20 \mathrm{~b}$ (see p. 76).

Body in side view oval or roundish. Epitheca low and small. Narrow girdle lists and inconspicuous left longitudinal list. In ventral view elliptical with rounded ends. Theca with coarse poroids all over. Megacytic stages common. Length ca. $45-49 \mu$.

Mediterranean, Adriatic, Tortugas between Iceland and Nova Scotia, Norwegian coast near Bergen. (Jörgensen.)

\section{Genus Phalacroma Stein (1883).}

Body usually not so much compressed laterally as in the next genus (Dinophysis). Epitheca rising above the transverse lists, which are not conspicuous and are uniformly developed. Chromatophores usually absent.

Whilst investigating the sand-inhabiting dinoflagellates at Port Erin, Isle of Man, it was found, as has already been stated by Miss Herdman 

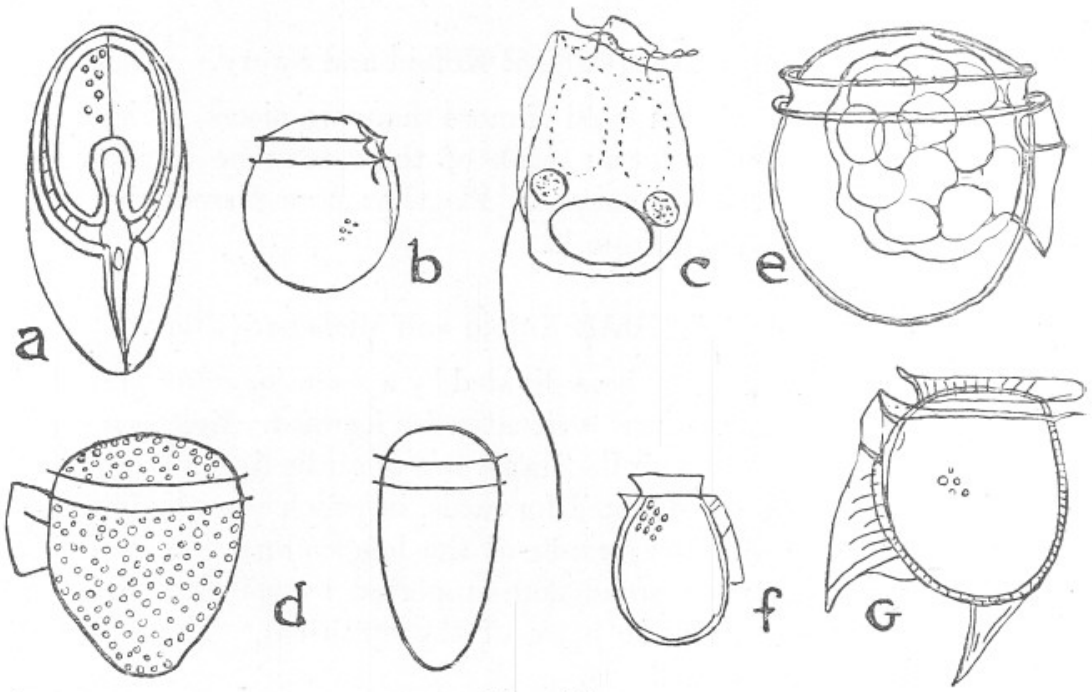

FIG. 20.

$a$ and $b$. Pseudophalacroma nasutum (Stein).

a. (?) Length. After Stein. Antero-ventral view. (b) $45 \mu$ long.

c. Phalacroma ebriolum C. Herdman. After Jörgensen. Lateral view.

ca. $40 \mu$ long, Port Erin, Isle of Man. After C. Herdman, 1924.

d. Phalacroma minutum Cleve.

$50 \mu$, W. Atlantic. After Cleve.

e. Phalacroma Rudgei Murray and Whitting.

After Murray and Whitting.

f. Dinophysis arctica Mereschkowsky.

$36 \mu$ long, Aretic waters. After Cleve, from Paulsen, 1908.

g. Dinophysis uracantha Stein.

$\times$ 400, Cadiz Bay. After Jörgensen.

(1924), that the variety of Amphidinium Kofoidi, called by her var. petasatum, was so closely related to Phalacroma that it could be divided, by suitable reagents, into two halves, which were held together by a finely striated narrow band possibly homologous with the band in the megacytic forms of the dinophysids. This form has the appearance of one of the laterally flattened Amphidinium species, but its epicone, which is slightly asymmetrical, is raised above the girdle and the girdle distinct, whilst there is also an indication of a left longitudinal list. Thus it looks like a simple and badly developed Phalacroma. There are, however, no poroids to be made out in the outer covering, and there appear to be true chromatophores in the plasma. It thus seems that we have a form intermediate between Amphidinium (those in the laterally flattened group) and Phalacroma, and this, as has already been pointed out by Miss Herdman (1924), bears out the suggestion of Kofoid and Swezy on 
the origin of the Dinophysidae from Amphidinium. Although it is unlike any known species of Phalacroma or Dinophysis in having no apparent sculpture on the theca, yet it seems that the covering is to be regarded as a true theca which can be divided into two halves and the girdle disarticulated. It has therefore been removed from Amphidinium and placed as the lowest member of the genus Phalacroma. To this must be added a new species also discovered by Miss Herdman, P. ebriolum.

Species :-Phalacroma Kofoidi C. Herdman, P. ebriolum C. Herdman, $P$. pulchellum Lebour, $P$. rotundatum (Claparède and Lachmann), P. irregulare n.sp., P. minutum Cleve.

Phalacroma Kofoidi C. Herdman (1924). Plate XI, figures $1 \mathrm{a}-1 \mathrm{~g}$.

Amphidinium Kofoidi var. petasatum C. Herdman, 1922.

Body much flattened laterally, in side view somewhat oval. Epitheca asymmetrical, low, but standing well out from the girdle which is deeply impressed, especially dorsally, and higher dorsally than ventrally. Sulcus oblique, very much hidden with incipient lists. Flagella distinct. Theca much like the pellicle of an Amphidinium, but separable into two halves with epitheca, girdle and hypotheca. Hypotheca bound round the seam by a striated band. Epitheca sometimes striated, otherwise the theca is apparently devoid of sculpture. Plasma yellowish with distinct yellow chromatophores radiating from the centre. Nucleus posterior and dorsal. Length $30-33 \mu$. A colourless variety is described by Miss Herdman (1924).

Port Erin, Isle of Man, in sand on the beach. (C. Herdman.)

Phalacroma ebriolum C. Herdman (1924).

Text-figure 20c.

Body roughly ellipsoidal, flattened laterally. Epicone small and tilted back to the dorsal side. Body seems to be covered by a very thin hyaline shell, which is produced as a slight list on the left border of the sulcus. Protoplasm clear and colourless, but usually containing coloured food bodies. Two large refractile bodies (? vacuoles) are situated in the anterior region of the hypocone. Nucleus posterior. Length ca. $40 \mu$.

Sand at Port Erin, Isle of Man. (C. Herdman.)

\section{Phalacroma pulchellum Lebour (1922).}

Plate XI, figures $2 \mathrm{a}-2 \mathrm{e}$.

Body rotund, very slightly flattened. Epitheca conspicuous. Girdle broad, deeply impressed with narrow lists. Sulcus extending on to the 
epitheca, the left longitudinal list extending about half-way down the hypotheca with conspicuous spines. Theca covered with small poroids, pores not apparent. Plasma pinkish to colourless. Megacytic forms with large fat globules and sculptureless median band frequent. Length $21-33 \mu$.

Plymouth Sound. Fairly common in summer.

Phalacroma rotundatum (Clap. and Lach.) (1889).

Plate XI, figures $3 \mathrm{a}-3 \mathrm{c}$.

Dinophysis rotundata Paulsen, 1908 ; Nordisches Plankton, p. 17.

Jörgensen (1923) has transferred Dinophysis rotundata and its related forms to Phalacroma in which he is followed here. Body nearly circular in lateral view. Much flattened. Girdle lists narrow but directed slightly forwards, sometimes finely striated. Left longitudinal list rather narrow, often widening posteriorly with conspicuous spines. Theca covered with poroids and pores; the latter irregularly scattered. Epitheca sometimes

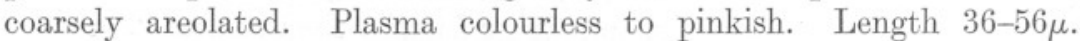
Megacytic forms frequent, the cell being filled with fatty globules.

Widely distributed in the Northern area, Atlantic, Baltic, Mediterranean, Bay of Biscay to Southern Levant, Golden Horn, Bosphorus. Common at Plymouth.

A smooth variety, var. laevis (Clap. and Lach.) Jörgensen, is thought by Jörgensen to be possibly identical with the Phalacroma Rudgei of Murray and Whitting. (Text-figure 20e.)

\section{Phalacroma irregulare n.sp. \\ Plate XI, figures $4 \mathrm{a}-4 \mathrm{c}$.}

Like $P$. rotundatum, but with an elongated, somewhat wedge-shaped hypotheca. Epitheca low, not covered by the girdle lists. Left longitudinal list reaching about half-way down the hypotheca with conspicuous spines. Theca with poroids each containing a pore, thus differing from those of $P$. rotundatum. Length $55-56 \mu$. Megacytic forms always seen, or those which have just divided with part of the border, which has a structure of fine poroids, attached. Plasma colourless to pinkish with large fat globules.

Plymouth Sound. Not common.

Phalacroma minutum Cleve (1900).

Text-figure 20d.

Paulsen, 1908; Nordisches Plankton, p. 19.

Cell compressed. Epitheca rounded in side view. Hypotheca rounded 
oval with blunt point. Girdle lists narrow. Left longitudinal list short with inconspicuous spines (perhaps imperfect). Theca with scattered poroids. Length $50 \mu$.

West Atlantic.

Considered by Jörgensen (1923) to be an imperfect specimen of $P$. acutum Schütt.

\section{Genus Dinophysis Ehrenberg.}

Cell compressed laterally, never wedge-shaped. Epitheca small or almost rudimentary with obliquely set girdle lists, the upper list being more or less funnel-shaped and often strengthened by radial ribs. Usually yellow chromatophores.

Species:-Dinophysis acuta Ehrb., D. norvegica Clap. and Lach., $D$. acuminata Clap. and Lach., D. arctica Mereschkowsky, D. ovum Schïtt, D. lenticula Pavillard, D. punctata Jörgensen, D. sphaerica Stein, D. caudata Kent, D. tripos Gourret, D. hastata Stein, D. Schuettii Murray and Whitting, D. uracantha Stein.

\section{Dinophysis acuta Ehrenberg (1839). Plate XII, figure 1.}

Paulsen, 1908; Nordisches Plankton, p. 13.

Cell oval with a blunt point posteriorly and ventrally, greatest breadth rather far behind the middle. Left longitudinal list running for about two-thirds along the hypotheca with long spines. Front girdle list forming a not very deep funnel. Theea with numerous small poroids, most or all of which enclose pores. Yellow chromatophores. Open sea form, widely distributed. Length 54-94 .

Atlantic, Arctic seas, North Sea, Skaggerak, Cattegat, Baltic, Mediterranean, Golden Horn, Bosphorus, English Channel, Brittany coast. Fairly common outside Plymouth Sound.

Dinophysis norvegica Claparède and Lachmann (1859).

Text-figure 21a (see p. 80).

Paulsen, 1908; Nordisches Plankton, p. 14.

Cell more pointed than the last, with the point of the hypotheca more central, the greatest breadth about the middle. Theca thick with coarse poroids and pores arranged as in D. acuta. Epitheca hidden by the rather flat funnel. Longitudinal left list narrower than in D. acuta, strongly

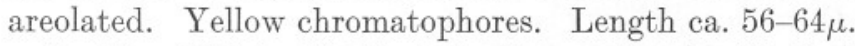

Neritic. Widely distributed, often confused with the last species.

Paulsen recognises two varieties, var. crassior, thicker with a broad 
margin, a Northern form, and var. debilior, thinner and more pointed with a narrow margin, a Southern form, Baltic, etc. Meunier's D. sphenoides (1910) probably belongs to the first variety.

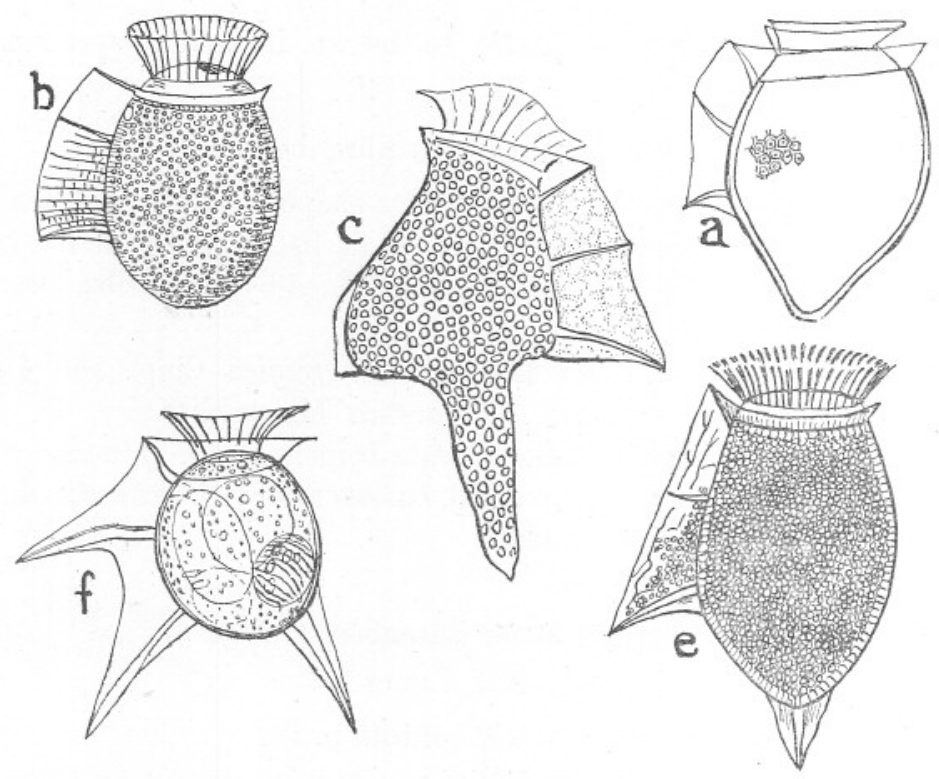

FIG. 21.

a. Dinophysis norvegica Clap. and Lach.

(?) $56 \mu$ long. From Paulsen, 1908, after Clap. and Lach.

b. Dinophysis sphaerica Stein.

(?) ca. $60 \mu$. After Stein.

c. Dinophysis caudata Kent.

(?) ca. $100 \mu$ long, outside Plymouth Sound. Drawing by Miss G. E. Webb.

e. Dinophysis hastata Stein.

(?) Size. After Stein.

f. Dinophysis Schuettii Murray and Whitting.

ca. $80 \mu$ long. After Murray and Whitting.

\section{Dinophysis acuminata Claparède and Lachmann (1859).}

Plate XII, figures 2a-2c.

Paulsen, 1908; Nordisches Plankton, p. 15.

Cell oval, strongly compressed, rounded behind with three or four small protuberances. Epitheca very small, hidden by the rather flat and low funnel. Left longitudinal list narrow. Theca with fine poroids and pores arranged as in D. acuta. Yellow chromatophores. Length $38-51 \mu$.

Widely distributed, chiefly in the north; Bosphorus. Common at Plymouth. 
Dinophysis arctica Mereschkowsky (1879).

Text-figure $20 f$.

Paulsen, 1908; Nordisches Plankton, p. 15.

Closely related to $D$. acuminata, but both shorter and broader without protuberances behind. Funnel and left longitudinal list very small. Poroids small or strongly marked. Length $36-42 \mu$.

Arctic species. Numerous in Polar stream.

Possibly Meunier's D. vertex (1910) belongs to this species.

\section{Dinophysis ovum Schütt (1895).}

Plate XII, figure 3.

Paulsen, 1908; Nordisches Plankton, p. 16.

Cell egg-shaped, broadest behind the middle, rounded behind without protuberances. Epitheca very small. Funnel rather deep. Left longitudinal list broad, supported by strong, usually thin spines. Theca with strong poroids and pores arranged as in D. acuta. Yellow chromatophores. Length $44-54 \mu$.

Open sea form, Atlantic, Mediterranean, Adriatic, English Channel. Rare near Plymouth.

var. baltica Paulsen, with the epitheca produced beyond the funnel and smaller, is probably another species.

\section{Dinophysis lenticula Pavillard (1916).}

Plate XII, figure 4.

Rather like $D$. acuminata, but smaller and without protuberances. Left longitudinal list short and fairly broad, often bent over to the right, reaching lower down the hypotheca than in D. acuminata. Yellow chromatophores. Structure of theca coarse as in D. acuta. Length ca. $40-43 \mu$.

Mediterranean, Adriatic, Plymouth Sound. This occurs closer inshore than D. acuminata.

\section{Dinophýsis punctata Jörgensen (1923). \\ Plate XII, figure 5.}

Like $D$. lenticula, but smaller, with a longer left longitudinal list, smaller epitheca, and fine poroids arranged as in D. acuta. Yellow chromatophores. Length $28-33 \mu$.

From salps in the Ionian Sea (Jörgensen). Common at Plymouth. Jörgensen suggests that this may be a small form of $D$. lenticula. 


\section{Dinophysis sphaerica Stein (1883).}

Text-figure $21 \mathrm{~b}$.

Paulsen, 1908; Nordisches Plankton, p. 16.

Cell regularly oval. Epitheca very small, hidden in the deep funnel. Left longitudinal list broad, strengthened by long spines. Conspicuous funnel, strongly ribbed. Poroids with pores in the centre of each. Length $57-60 \mu$.

Warm seas. Once found in the Skaggerak.

\section{Dinophysis caudata Kent (1882).}

Text-figure 21c.

Dinophysis homunculus Paulsen, 1908; Nordisches Plankton, p. 19 (in part).

Epitheca almost absent, hidden in the deep funnel. Hypotheca long, narrowing behind into a drawn-out point which is often toothed. Left longitudinal list broad, often reticulated. A small dorsal fin often present. Theca strongly areolated. Length ca. $100 \mu$. A very variable species. Open sea forms.

Warm water, Atlantic, Indian Ocean, Mediterranean, Adriatic, English Channel, Brittany coast, North Sea, Norwegian seas, Golden Horn, Bosphorus. Occasionally caught near Plymouth.

Dinophysis tripos Gourret (1883).

Text-figure 22 .

Dinophysis homunculus var. tripos Paulsen, 1908; Nordisches Plankton, p. 19.

This was for some time regarded as a variety of D. caudata $(=D$. homunculus). It is similar to that species, but with two points to the hypotheca

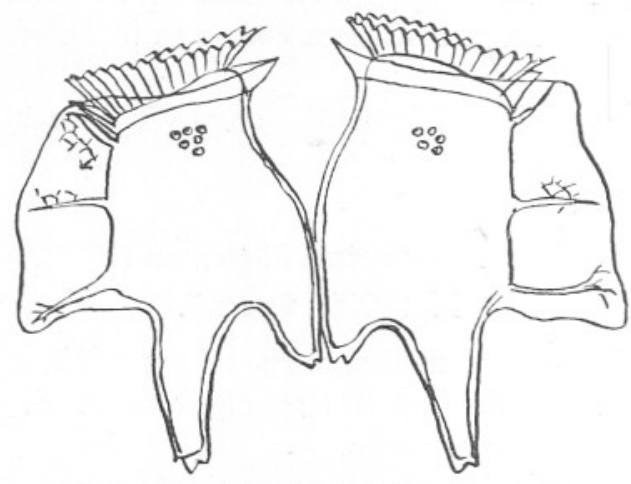

Fig. 22. Dinophysis tripos Gourret.

ca. $100 \mu$ long, English Channel. From drawing by Mrs. Sexton. 
instead of one, the dorsal process being the shorter. "Twin forms," with two individuals joined, are common. Length ca. $100 \mu$.

Open sea form, warm seas. Frequent in the Channel; found from Scotland to Greenland; coast of Norway; S. Africa to Australia; perennial in the Mediterranean.

\section{Dinophysis hastata Stein (1883). Text-figure 21 e.}

Paulsen, 1908; Nordisches Plankton, p. 13.

Cell egg-shaped, broadest behind the middle. Epitheca very small, flattened, quite hidden in the rather deep striated funnel. Spines on the left longitudinal list long, the hind one longest. Hypotheca bears a strong winged spine posteriorly. Sculpture strong, partly on the longitudinal list. Length (?).

Warm seas, Mediterranean, Atlantic; rarely in the north, Scotland, Cattegat, Bosphorus.

Dinophysis Schuettii Murray and Whitting (1899).

$$
\text { Text-figure } 21 \mathrm{f} .
$$

Paulsen, 1908; Nordisches Plankton, p. 18.

Cell in side view somewhat circular, crowned by the striated funnel so that the epitheca has almost vanished. Left longitudinal list very broad, supported by long strong spines which project outside the membrane. Another long winged spine dorsally. Theca with scattered poroids. Length (with spines) ca. $80 \mu$.

Tropical Atlantic species. Rare in the Gulf Stream, Mediterranean.

Jörgensen (1923) suggests that Ostenfeld's record from $59^{\circ} 47^{\prime} \mathrm{N}$., $25^{\circ} 53^{\prime} \mathrm{W}$. (about midway between the northern point of Scotland and the southern point of Greenland) really refers to some other species, possibly D. uracantha.

\section{Dinophysis uracantha Stein (1883).}

Text-figure $20 \mathrm{~g}$.

Cell in side view more or less asymmetrically roundish oval. Funnel ribbed, well developed. Left longitudinal list very large, running nearly to the hypotheca, the lower part twice as broad as the upper and prolonged into a long downward curving acute tongue supported by a long curved spine. Terminal spine long and strongly developed, with narrow lists, or these may be absent. Theca with small or thick-walled areoles. Length (?).

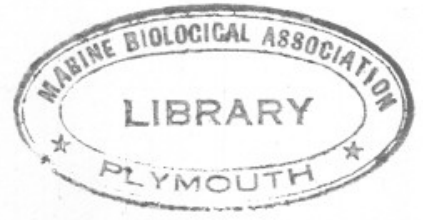


Mediterranean, Gulf of Guinea, Southern Atlantic. Once on the Norwegian coast at Bergen. (Jörgensen.)

\section{Genus Amphisolenia Stein (1883).}

Epitheca a small flat plate. Hypotheca much drawn-out longitudinally. Shape varied. Transverse lists like Dinophysis. Sulcus only running for a short distance behind the girdle, weakly developed, accompanied by a membranous list. Sculpture very weak, almost absent in some species. Chromatophores not known. Tropical genus. Very few Northern forms.

Species :-Amphisolenia globifera Stein (1883), A. inflata Murray and Whitting.

\section{Amphisolenia globifera Stein (1883).}

Text-figure 23a.

Paulsen, 1908; Nordisches Plankton, p. 20.

Epitheca almost absent. Hypotheca long, spindle-shaped, swollen behind into a round mass. Length $200 \mu$.

Warm seas, Atlantic, Mediterranean, seldom in the North.

Amphisolenia inflata Murray and Whitting (1889).

Text-figure $23 \mathrm{~b}$.

Paulsen, 1908; Nordisches Plankton, p. 21.

Epitheca almost absent. Hypotheca oval, swollen in the middle, at both ends suddenly narrowing into long drawn-out ends. Pointed behind. Length (?).

Tropical species, Atlantic, seldom in the North.

\section{Family GLENODINIIDAE fam. nov.}

With theca composed of epitheca, girdle and hypotheca, not divided up into plates and not divided by a seam. Frequently, if not always, the theca, on treatment with reagents, shows a pattern of numerous small platelets, which apparently cannot be disassociated. These are chiefly fresh-water species. The marine forms are insufficiently known, and it is quite conceivable that further research will show that they belong to different genera. Already three formerly included here have been removed to other genera. These are G. foliaceum Stein to the new genus Kryptoperidinium Lindemann, G. trochoideum to Peridinium and G. bipes to a new genus closely related to Peridinium and named by the writer Minuscula. 

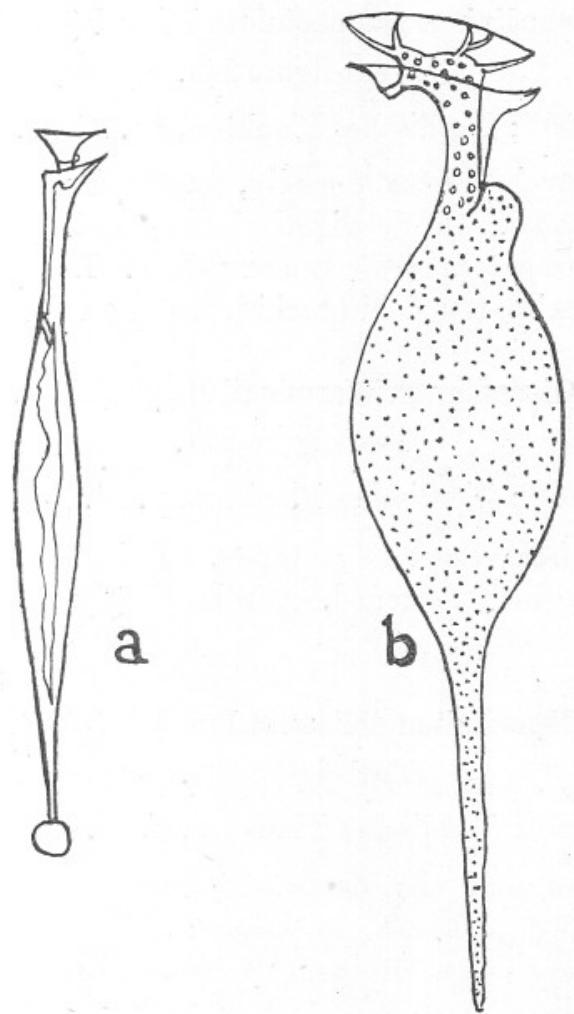

Fig. 23.

a. Amphisolenia globifera Stein. $200 \mu$ long. After Stein.

b. Amphisolenia inflata Murray and Whitting.

(?) Size, Atlantic. After Murray and Whitting.

There remain in our area G. danicum Paulsen, G. gymnodinium Penard, G. obliquum Pouchet, and G. Warmingii Bergh. The three last are very little known. G. danicum appears to have no plates, although it has not been exhaustively treated with stains and reagents. Miss Herdman has lately added one more G. monensis, from Port Erin, in which she finds no plates.

\section{Genus Glenodinium (Ehrenberg) Stein.}

With the characters of the family. No apical pore. Mostly freshwater and brackish.

Species:-Glenodinium gymnodinium Penard, G. Warmingii Bergh, G. obliquum Pouchet, G. danicum Pouchet, G. monensis C. Herdman. 


\section{Glenodinium gymnodinium Penard (1891).}

Text-figure 24a.

Paulsen, 1908; Nordisches Plankton, pp. 22-23.

Cell roundish oval, convex dorsally, flattened ventrally. Epi- and hypothecae sub-equal. Girdle slightly left-handed. Sulcus reaching to the antapex. Chromatophores green or yellow. Length $40 \mu$.

Fresh-water species, found in brackish water on the coast of Finland.

\section{Glenodinium Warmingii Bergh (1881).}

Text-figure $24 \mathrm{~b}$.

Paulsen, 1908; Nordisches Plankton, p. 24.

Cell flattened from apex to antapex. Epitheca shorter than the hypotheca. Hypotheca flattened. Girdle slightly left-handed. Sulcus narrow. Length $22-28 \mu$.

Little Belt.

Glenodinium obliquum Pouchet (1883).

Text-figure 24c.

Paulsen, 1908; Nordisches Plankton, p. 25.

Cell dome-shaped, somewhat flattened from apex to antapex. Epi- and hypothecae rounded, epitheca the larger; girdle apparently not displaced. Sulcus very short. Brown chromatophores. Red stigma sometimes present. Size (?).

Coasts of Brittany and Mediterranean.

Glenodinium danicum Paulsen (1907).

Plate XII, figure 6.

Paulsen, 1908; Nordisches Plankton, p. 23.

Cell nearly round, with a small point at the apex. Girdle left-handed, displaced about a girdle width. Sulcus narrow, broadening slightly posteriorly, sometimes with a small spine on the left. Length $28-36 \mu$.

Skaggerak, Barents Sea, Plymouth Sound.

Meunier (1910) has found this species with a large cyst inside, which emerges by the girdle coming away from the centre. This cyst has two spines antapically. The specimens from Plymouth were not exhaustively examined.

Glenodinium monensis C. Herdman (1923).

Text-figure 24d.

Body rotund or broadly bi-conical, with bluntly rounded apices and flattened dorso-ventrally to about half its transverse diameter. Total 


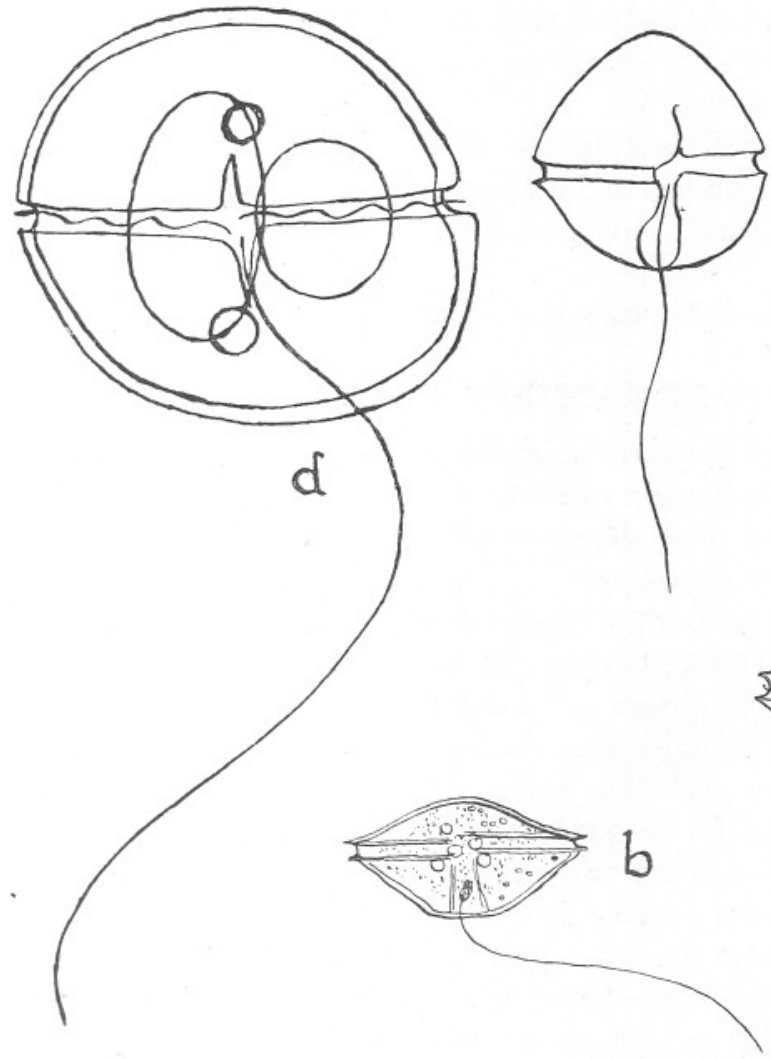

a

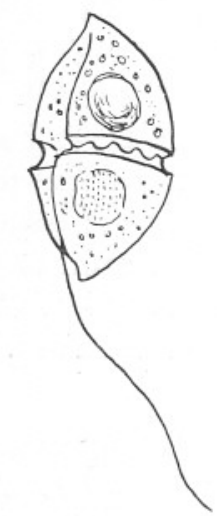

FIG. 24.

a. Glenodinium gymnodinium Penard.

(?) $40 \mu$ long. Ventral and side views. After Penard.

b. Glenodinium Warmingii Bergh.

$22 \mu$, Little Belt. After Bergh.

c. Glenodinium obliquum Pouchet.

(?) Size, coast of Brittany. After Pouchet.

d. Glenodinium monensis C. Herdman.

ca. $25 \mu$ long, Port Erin. Drawing by C. Herdman, 1923.

length slightly less than the greatest transdiameter. Epicone and hypocone approximately equal in size, but not set squarely one on the other, the epicone projecting slightly to the right and the hypocone to the left. The girdle runs round the body equatorially, its ends meeting with very slight displacement. The sulcus is extremely short and projects about equally on epi- and hypocones, while the longitudinal flagellum is about three times the length of the body. Two red pusules (?) open into it at either end ; the large ovoid nucleus is nearly central in position. Another colourless highly refractive body is also present. The cytoplasm is 
yellowish green. The whole body is enclosed in a clear and apparently structureless pellicle, which is shed from time to time, splitting in two at the girdle. Length about $25 \mu$.

This species occurred at Port Erin, Isle of Man, in large numbers from time to time during the summer of 1922, in the inner harbour close to the concrete steps. It appears to live equally well in salt or fresh water. (C. Herdman.)

Meunier's Glenodinium inflatum from the Barents Sea is not sufficiently characterised.

\section{Family PERIDINIIDAE Kofoid.}

With theca composed of epitheca, girdle and hypotheca, divided up into plates. Apical pore usually present.

There have been many ways suggested of numbering the plates. The system of Kofoid (1909) is used here, as it seems the simplest and most useful. The most important of the other suggestions are by Stein (1883), Bütschli (1885), Schütt (1896), Paulsen (1908) and Fauré-Fremiet (1908).

Kofoid uses the girdle as a basis and numbers the plates with reference to it in transverse series running from the left dorsally to the right. The plates round the apex are called the apicals and designated by one acute accent mark '; those round the girdle and anterior to it are called the precingulars and designated by two marks "; whilst in between the apicals and precingulars there may be one or more plates which never form a complete ring and are known as the anterior intercalaries and designated by $a$. The girdle itself may be of one piece only or divided, the plates designated by $g$. These are often omitted in writing the formula of plates, as the girdle plates are very often unknown.

The plates of the hypotheca are also in series and indicated in the same way : those below the girdle, called the postcingulars, designated by three marks "I ; those at the antapex, the antapicals, designated by four marks "'"'; and there may be posterior intercalaries between antapicals and postcingulars, designated by $p$. Thus the plate formula for a typical species of Peridinium would be apicals 4, anterior intercalaries 3, precingulars 7 , postcingulars 5, no posterior intercalaries, antapicals 2, or shortly $4^{\prime} 3 a{ }^{\prime \prime \prime} 5^{\prime \prime \prime} 2^{\prime \prime \prime \prime}$ (Text-figure 25). In addition there are small plates in the sulcal region, forming what is known as the ventral area. These also are usually insufficiently known and do not come into the general plate formula.

\section{Genus Protoceratium Bergh (1881).}

Cell a somewhat angular oval or sphere. Girdle equatorial or slightly in front of the centre. Theca strongly reticulated so as to obscure the plates, sometimes with spines at the intersection of the meshes. Inter- 

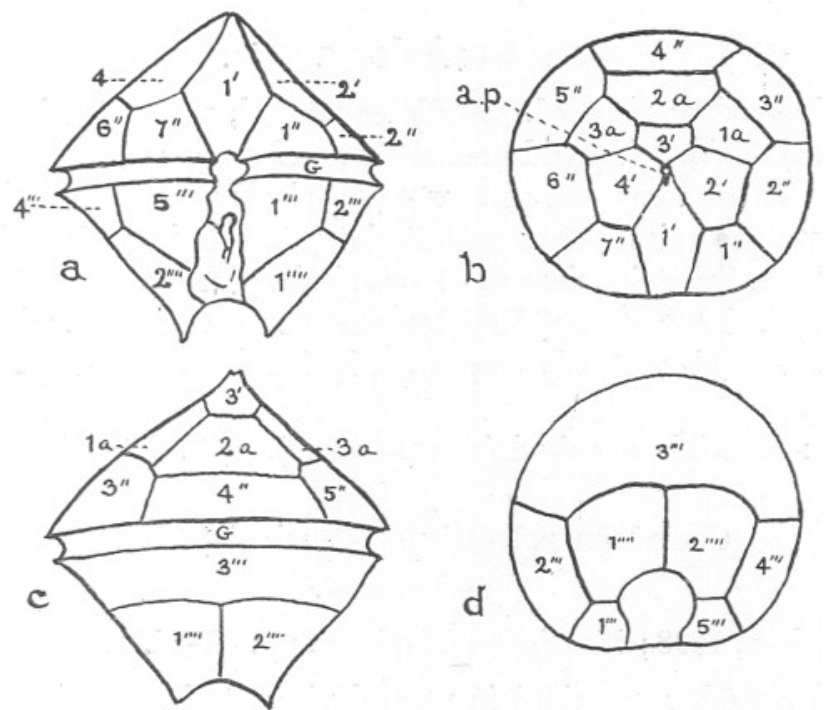

FIG. 25. Diagram of numbering of Plates of Peridinium.

calary bands sometimes very broad. Plate formula $2^{\prime} 6^{\prime \prime} 6^{\prime \prime \prime} 1 p 1^{\prime \prime \prime \prime}$, or it is possible that there are 3 antapicals, which may merge into the ventral area, but the first formula seems to be the more probable. There is no apparent apical pore.

One species :-Protoceratium reticulatum (Claparède and Lachmann).

Protoceratium reticulatum (Claparède and Lachmann).

Plate XII, figures 7a-7c.

Paulsen, 1908; Nordisches Plankton, p. 27.

Epi- and hypothecae sub-equal or hypotheca slightly the longer. Rounded angular. Girdle left-handed, displaced about a girdle width, with narrow lists supported by spines. Ventral area reaching not quite to the antapex, with very inconspicuous lists to the sulcus. Theca strongly reticulated and often with spicules. Intercalary bands present or absent. First apical very narrow, the second polygonal and occupying the anterior end. Six large precingulars. Girdle apparently not divided. Hypotheca with 6 postcingulars, the first shorter, with a small posterior intercalary plate behind it. Two long plates occupying most of the ventral area and indenting the antapical : these possibly to be regarded as antapicals. Plates very difficult to see on account of the reticulations. Length $28-56 \mu$. Neritic.

Very common Northern species, Bosphorus, Adriatic. Abundant at Plymouth. 


\section{Genus Goniodoma Stein.}

Cell polygonal or rounded. Girdle equatorial, with conspicuous lists supported by spine. Ventral area short and broad, made up of several platelets. Theca composed of 3 or 4 (?) apicals with an apical closing platelet over the apical pore; no anterior intercalaries ; 7 precingulars, 6 girdle plates, 5 postcingulars and 3 antapicals. Plate formula $3^{\prime}$ or $4^{\prime}$ (?) $7^{\prime \prime} 6 g 5^{\prime \prime \prime} 3^{\prime \prime \prime \prime}$. Lindemann (1923) describes G. lacustris n.sp. with 9 precingulars. As this was only seen once, he is not sure of its position in this genus.

Species :-Goniodoma polyedricum (Pouchet), (?) G. Ostenfeldii Paulsen.

\section{Goniodoma polyedricum (Pouchet) (1883).}

Text-figure 26.

Paulsen, 1908; Nordisches Plankton, pp. 33-34.

Cell polyhedral, seven-sided in ventral view ; epitheca with 3 , hypotheca with 2 angles. Transverse section nearly circular. Girdle equatorial, left-handed, with strong lists supported by spines. Theca strongly
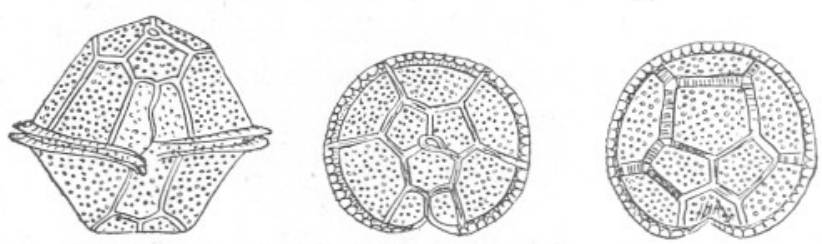

Fig. 26. Goniodoma polyedricum (Pouchet).

(?) $60 \mu$ long. After Paulsen, from Stein, 1908.

sculptured, with poroids (or pores ?). Intercalary bands narrow or broad. Schiitt (1887) has seen swarm spores. Cell contents brown. Length $48-60 \mu$.

Sub-tropical, rare in the north in the region of the Gulf Stream, Red Sea, Adriatic, Indian Seas, English Channel.

\section{Goniodoma Ostenfeldii Paulsen (1904). \\ Text-figure 27.}

Paulsen, 1908; Nordisches Plankton, p. 34.

This species had not had its plates worked out sufficiently to characterise it. Possibly it is a species of Goniaulax and very like the small species described below as Goniaulax orientalis. It is rounded with a conical epitheca; left-handed, theca very thin. There are apparently 

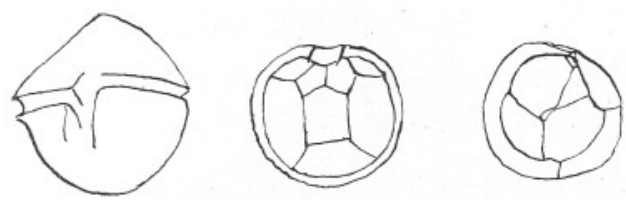

Fig. 27. Goniodoma Ostenfeldii Paulsen.

(?) $48 \mu$ long, Iceland. After Paulsen.

4 apicals, the first very oblique, and 3 antapicals. It looks as though these latter might be interpreted as one posterior intercalary and part of the ventral area. Length $48-60 \mu$. Neritic.

Arctic species; very plentiful in Iceland, rare in the Baltic and the North Sea.

\section{Genus Goniaulax Diesing (1866).}

Variable in shape. Girdle about equatorial, left-handed, displaced from one-half to seven times its own width, sometimes with a slight overhang. Plates : apicals 3-5, anterior intercalaries 0-2, precingulars 6 , girdle plates 6 , postcingulars 6 , posterior intercalary 1 , antapical 1 , or $3^{\prime}-5^{\prime}$, $0-2 a, 6^{\prime \prime}, 6 g, 6^{\prime \prime \prime}, 1^{\prime \prime \prime \prime}$. Longitudinal furrow occupying the whole of the ventral area, which slightly indents the epitheca and consists of 1 anterior, about 4 intermediate and 1 posterior plate. The first apical is usually narrow, extending posteriorly to the anterior plate of the ventral area, thus parting plates $1^{\prime \prime}$ and $6^{\prime \prime}$. It bears at its apex a platelet covering the apical pore. Plates with pores. A large ventral pore occurs on the right near the junction of the first apical and the plate to its right. Theca divides obliquely in fission. Chain formation may occur. Chromatophores yellow to dark brown. Fresh-water, brackish and marine.

For a detailed description and general account of this genus see Kofoid (1911), from which the above is adapted. He divides it into four subgenera, all of which are not noted here, as two of them do not occur in this area. We therefore divide them into (1) Goniaulax proper and (2) the sub-genus Steiniella Kofoid, the latter including only Steiniella fragilis, which Kofoid has discovered to be a Goniaulax.

All synonymy is referred to the above paper by Kofoid.

Lindemann (1923) finds a good deal of variation in the plates.

Species:-1. Goniaulax proper: Goniaulax spinifera (Claparède and Lachmann). G. digitale (Pouchet), G. unicornis n.sp., G. orientalis Lindemann, G. polygramma Stein, G. scrippsae Kofoid, G. turbynei Murray and Whitting, G. Diegensis Kofoid, G. tamarensis n.sp., G. apiculata (Penard), G. triacantha Jörgensen, G. polyedra Stein, G. longispina n.sp., G. catenata (Levander).

2. Steiniella: Goniaulax fragitis (Schïtt). 


\section{Sub-genus Goniaulax proper.}

Body spheroidal or polyhedral, not greatly elongated, apical closing platelet not carried over upon the dorsal side.

Goniaulax spinifera (Claparède and Lachmann) (1866).

Plate XIII, figures $1 \mathrm{a}$ and $1 \mathrm{~b}$.

Kofoid, 1911, pp. 209-214.

Goniaulax Levanderi Paulsen, 1908; Nordisches Plankton, pp. 30-31. Goniaulax Mangini Fauré-Fremiet (1908).

Cell more or less rotund, somewhat elongated anteriorly. Epitheca with convex sides, with or without two or more antapical spines. Girdle wide, oblique, displaced twice its width or more, with an overhang of 1-2 girdle widths, deeply excavated, without lists. Longitudinal furrow, not expanding much posteriorly, but expanding to the left opposite the right end of the girdle. Plate formula $3^{\prime} 0 a 6^{\prime \prime} 6^{\prime \prime \prime} 1 p 1^{\prime \prime \prime \prime}$. Surface with a few large pores, sometimes reticulated. Chromatophores dark yellowish brown. Length $24-50 \mu$, usually $35-40 \mu$. Neritic.

Distribution insufficiently known, as it is frequently confounded with G. digitale. Known records are from San Diego, Alaska, Norway, Finland, Zuider Zee, Eastern Baltic, Iceland, Aral Sea, Adriatic, Golden Horn, Brittany coast, Plymouth.

At Plymouth this is quite the commonest Goniaulax.

Peridinium vexans Murray and Whitting (Paulsen, 1908, p. 63) is probably this species.

\section{Goniaulax digitale (Pouchet). \\ Text-figure 28a.}

Kofoid, 1911, pp. 214-217.

Goniaulax spinifera Paulsen, 1908; Nordisches Plankton, pp. 28-29.

Larger than G. spinifera, less rotund, with less overhang. Epitheca sub-conical, often slightly angled. Generally two stout antapical spines. Longitudinal furrow not abruptly widened opposite the right end of the girdle. Surface of theca usually heavily reticulated. Stout apical horn. Girdle displaced $2-2.5$ girdle widths, with an overhang of $1-1 \cdot 25$ widths ; furrow deeply impressed with narrow lists supported by spines. Plate formula $3^{\prime} 0 a 6^{\prime \prime} 6^{\prime \prime \prime} 1 p 1^{\prime \prime \prime \prime}$. Length $50-75 \mu$.

Alaska, California, Faroes, Iceland, North Sea, English Channel, Brittany coast, Naples, Adriatic, Caspian Sea.

\section{Goniaulax unicornis n.sp.}

Plate XIII, figures $2 \mathrm{a}$ and $2 \mathrm{~b}$.

A minute brown species looking very much like Peridinium trochoideum, 


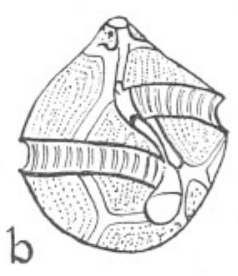

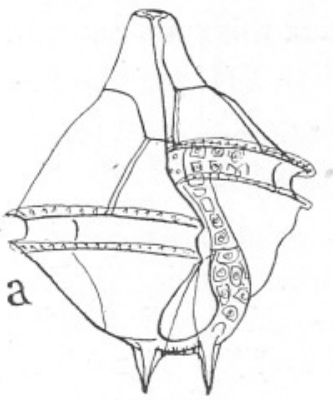

FIG. 28.

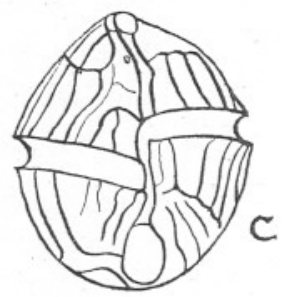

a. Goniaulax digitale (Pouchet).

(?) $50 \mu$ long, San Diego, California. After Kofoid.

b. Goniaulax scrippsae Kofoid.

$35 \mu$ long, San Pedro Harbour, California. After Kofoid.

c. Goniaulax turbynei Murray and Whitting.

$47 \mu$ long, San Diego, California. After Kofoid.

but with a conspicuous hollow horn on the left side of the antapex. Cell with a rounded conical epitheca and hemispherical hypotheca interrupted by the horn, which is short and thick, and sometimes with a fine point. Epitheca nearly twice as long as the hypotheca. Girdle very slightly displaced without overhang, very much excavated with narrow lists. Longitudinal furrow short, not reaching the antapex. Plate formula $3^{\prime} 0 a 6^{\prime \prime} 6^{\prime \prime \prime} 1 p 1^{\prime \prime \prime \prime}$. Theca smooth. The first apical rather broad and more like Peridinium than Goniaulax. Chromatophores dark brown. Length $28-30 \mu$.

Plymouth Sound, frequent, but so small that it gets through the nets.

Goniaulax orientalis Lindemann (1923).

Plate XIII, figures $3 a-3 d$.

Cell round, with roundish-conical apex, the sides of both epi- and hypothecae convex, the antapex slightly flattened. Girdle displaced from $\frac{1}{2}-1$ girdle width, excavated without or with hardly perceptible lists. Longitudinal furrow running up the epitheca for a short way, or not at all, broadening slightly posteriorly with a minute spine each side, which may be absent. Plate formula $3^{\prime} 0 a 6^{\prime \prime} 6^{\prime \prime \prime} 1 p 1^{\prime \prime \prime \prime}$. The first apical is very oblique, 4 -sided. First postcingular very small. Theca smooth in the Plymouth forms, areolated strongly in those from the Bosphorus. Brown chromatophores. Length $28-45 \mu$.

Bosphorus, English Channel, Plymouth.

The Plymouth specimens agree so closely in plate structure, that they are almost certainly this species.

G. orientalis is very like Goniodoma Ostenfeldii (see above under that species). 


\section{Goniaulax polygramma Stein (1883). \\ Plate XIII, figures $4 \mathrm{a}-4 \mathrm{c}$.}

Paulsen, 1908; Nordisches Plankton, pp. 28-29.

Kofoid, 1911, pp. 229-233.

Cell elongated, epitheca pointed, hypotheca rounded. Girdle displaced a little more than its width. Longitudinal furrow widening posteriorly, with 2 or more short unequal antapical spines, rarely only 1, or none. Plate formula $3^{\prime} 0 a 6^{\prime \prime} 6^{\prime \prime \prime} 1 p 1^{\prime \prime \prime \prime}$. Narrow first apical. Theca with conspicuous longitudinal ridges, reticulate with distinct pores. Length $42-75 \mu$.

San Diego, Atlantic, Indian Ocean, Gulf of Siam, Japanese waters, S. Pacific, Red Sea, Naples, Adriatic, English Channel (Plymouth), Brittany coast. Paulsen says it often occurs damaged in the Northern waters.

\section{Goniaulax scrippsae Kofoid (1911).}

Text-figure 28b.

Kofoid, 1911, pp. 228-229.

A very small rotund species with small apical horn, much displaced girdle, surface with fine striations, principally in the longitudinal direction. No antapical spines. Girdle displaced 2-3 girdle widths. Longitudinal furrow deeply indented with marginal ridges, but no lists. Plate formula $3^{\prime} 0 a 6^{\prime \prime} 6^{\prime \prime \prime} 1 p 1^{\prime \prime \prime \prime}$. Surface characteristically marked with fine sub-parallel lines, mainly longitudinal, but in some places parallel with the intercalary bands. Length $29-39 \mu$.

San Diego, Plymouth Sound.

Goniaulax turbynei Murray and Whitting (1889).

Text-figure $28 \mathrm{c}$.

Kofoid, 1911, pp. 225-227.

(?) Glenodinium ovatum Fauré-Fremiet, 1908.

This is a warm-water species first recorded by Murray and Whitting from the tropical Atlantic. Kofoid thinks it possible that FauréFremiet's Glenodinium ovatum from the coast of Brittany may be this species, for which reason it is included here.

A small ovoid species. Girdle displaced 1-1.5 girdle widths, without marked overhang. Linear markings more or less well developed. Plate formula $3^{\prime} 0 a 6^{\prime \prime} 6^{\prime \prime \prime} 1 p 1^{\prime \prime \prime \prime}$. Length $47 \mu$. No apical horn nor antapical spines. Differs from $G$. scrippsae in the absence of overhang of the girdle.

Tropical Atlantic, San Diego, (?) coast of Brittany. 


\title{
Goniaulax Diegensis Kofoid (1911).
}

\author{
Plate XIII, figures 5a-5d.
}

Kofoid, 1911, p. 217.

A species occasionally found at Plymouth appears to be identical with this one described by Kofoid from California. Cell nearly spherical, with an undulating outline, slightly longer than broad; stout short apical horn, 2-4 antapical spines. Girdle very slightly overhanging, displaced from 3-4 girdle widths, strongly excavated, without lists. Plate formula $4^{\prime} 0 a 6^{\prime \prime} 6^{\prime \prime \prime} 1 p 1^{\prime \prime \prime \prime}$. First apical long, slender and irregular ; fourth apical very small ; 2-4 spines, usually with fins, are borne by the antapical plate, but these are very inconspicuous. Theca strongly reticulate, the broad intercalary bands sparsely dotted. Plasma pale yellow or yellowish brown. Length $56-64 \mu$.

San Diego, California; English Channel (Plymouth Sound).

\section{Goniaulax Tamarensis n.sp. \\ Plate XIV, figures 1a-1d.}

This little species was found up the River Tamar in estuarine water. Cell roundish, rather longer than broad. No apical horn; 2 very small antapical spines. Girdle hardly displaced a girdle width, with no overhang, with no lists. Longitudinal furrow much expanded posteriorly. Plate formula $4^{\prime} 0 a 6^{\prime \prime} 6^{\prime \prime \prime} 1 p 1^{\prime \prime \prime \prime}$. First apical rather broad. Theca smooth. Length $36 \mu$.

Found only in the River Tamar estuary, near Plymouth.

\section{Goniaulax apiculata (Penard) (1891).}

Text-figure 29.

Paulsen, 1908; Nordisches Plankton, p. 31.

Cell oval, epitheca with a small apical horn. Girdle displaced 1-2 girdle widths without overhang. Hypotheca rounded. Longitudinal

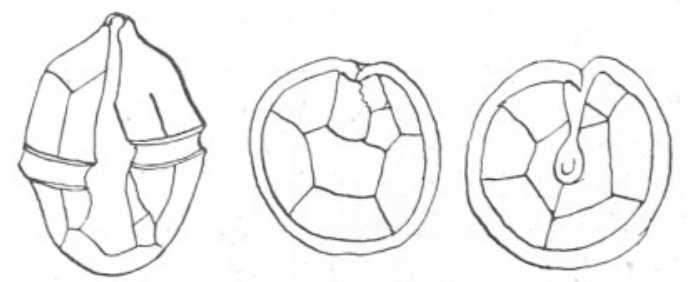

FIG. 29. Goniaulax apiculata (Penard).

(?) Size. From Paulsen, 1908; after Entz, 1904. 
furrow broad, with lists supported by spines. Theca reticulated. Plate formula $4^{\prime} \mathrm{Oa}$ (or $3^{\prime} 1 a$ ) $6^{\prime \prime} 6^{\prime \prime \prime} 1 p 1^{\prime \prime \prime \prime}$. Length $34-62 \mu$.

Fresh water; rare in brackish water. Aral Sea.

Goniaulax triacantha Jörgensen (1899).

Plate XIV, figure 2 and Text-figure 30.

Paulsen, 1908; Nordisches Plankton, pp. 28-29.

Kofoid, 1911, pp. 221-225.

Amylax lata Meunier, 1910.

A'small species flattened dorso-ventrally; hypotheca rotund; epitheca with concave sides, obliquely truncated apex. Girdle slightly displaced; longitudinal furrow spreading posteriorly to the right; 5-7 antapical
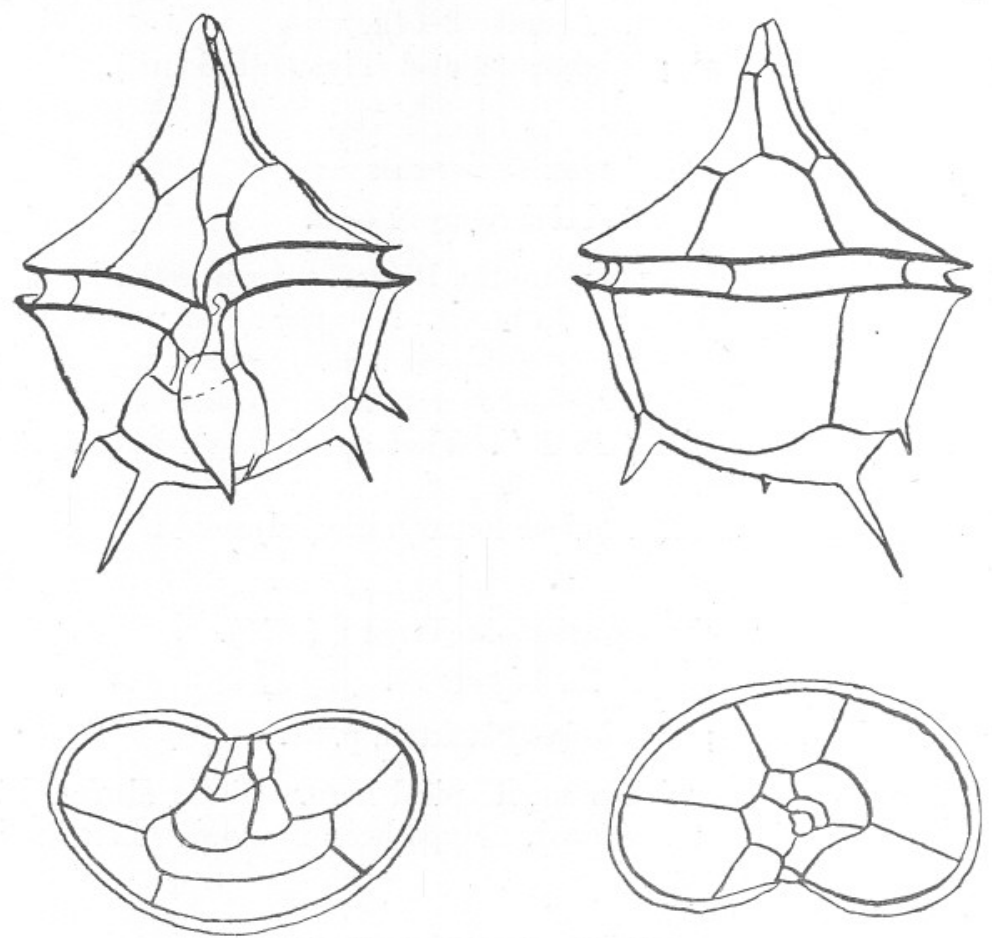

Frg. 30. Goniaulax tricantha Jörgensen.

Plate structure. After Kofoid.

spines. Surface finely reticulate, sometimes with linear markings. Girdle displaced 1 girdle width, deeply excavated, without lists. Plate formula $3^{\prime} 2 a 6^{\prime \prime} 6^{\prime \prime \prime} 1 p 1^{\prime \prime \prime \prime}$. Length $42-60 \mu$ (without spines).

Alaska, Norway, Spitzbergen, Iceland, Shetland and the Faroes, Skaggerak, Cattegat, North Sea, North Atlantic, Baltic, Gulfs of Bothnia 
and Finland, English Channel (Plymouth). As well as occurring in Plymouth Sound it was found in the Yealm estuary, near Plymouth.

\section{Goniaulax polyedra Stein (1883). Plate XIV, figures $3 \mathrm{a}-3 \mathrm{~d}$.}

Paulsen, 1908; Nordisches Plankton, pp. 31-32.

Kofoid, 1911, p. 238.

Small, angular, polyhedral; with ridges along the sutures, sometimes enlarged into bands. Girdle displaced 1-2 girdle widths. Surface regularly pitted. Plate formula $4^{\prime} 2 a 6^{\prime \prime} 6^{\prime \prime \prime} 1 p 1^{\prime \prime \prime \prime}$, the fourth apical minute and the anterior intercalaries ventral. Length $42-54 \mu$. Cell contents deep brown. Neritic.

Widely distributed in temperate and sub-tropical waters. Denmark, Norway, Faroes, N. Scotland, N. Atlantic, Baltic, Mediterranean, Adriatic, Bosphorus, coast of California, Australia, English Channel (Plymouth), Brittany coast.

This species is one of the chief causes of "red water," the water in certain areas (Kofoid, 1911, p. 242) being coloured a deep red by it. It is also highly phosphorescent.

\section{Goniaulax longispina n.sp. \\ Plate XIV, figures $4 \mathrm{a}-4 \mathrm{c}$.}

This species appeared in numbers once in Plymouth Sound (7.7.21). Cell elongated, rather suggesting Peridinium Steinii. Epitheca with convex sides, longer than the hypotheca, tapering to an apical horn. Hypotheca hemispherical, with two very conspicuous winged spines on the antapical plate, curving towards each other. Girdle displaced hardly more than a girdle width, excavated. Longitudinal furrow not very broad. Plate formula $4^{\prime} 2 a 6^{\prime \prime} 6^{\prime \prime \prime} 1 p 1^{\prime \prime \prime \prime}$. First apical long and narrow, the others very small. Anterior intercalaries ventral. Theca with conspicuous reticulations, the intercalary bands sometimes very broad with mosaic-like sculpture of squares. Cell contents dark yellow. Length $56 \mu$ with spines.

Plymouth Sound.

Goniaulax catenata (Levander) (1894).

Text-figure 31a (see p. 98).

Kofoid, 1911, pp. 287-293.

Peridinium catenatum Paulsen, 1908; Nordisches Plankton, pp.63-65.

This species, described by Levander as a Peridinium, has been shown by Kofoid to be a Goniaulax related to G. triacantha. It is specially 
interesting because of its habit of forming chains. Cell minute, with the general form of a Peridinium, but the plates of a Goniaulax. Plate formula $4^{\prime} 4 a 6^{\prime \prime} 6^{\prime \prime \prime} 1 p 1^{\prime \prime \prime \prime}$. Posterior plate of ventral area exceeding 0.5 transdiameters in width. Several antapical spines present. Ringshaped starch grains. Fission with chain formation. Body rounded, flattened dorso-ventrally. Girdle displaced 1 girdle width, without overhang; furrow deeply impressed, no lists. Ventral area exceptionally

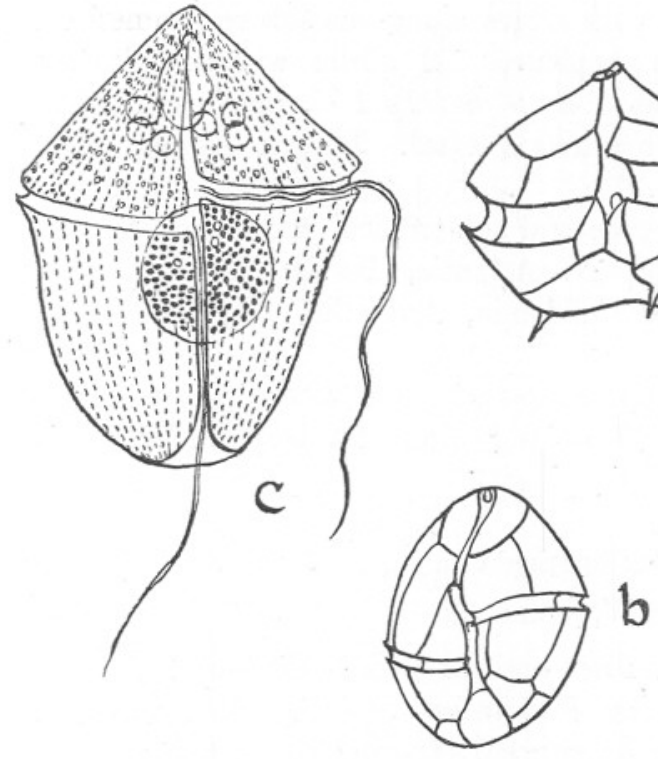

FIG. 31 . a

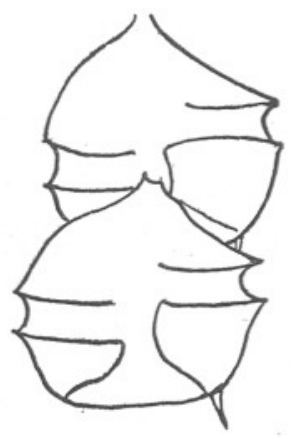

a. Goniaulax catenata (Levander). $30 \mu$ long. After Kofoid.

b. Goniaulax fragilis (Schütt). $84 \mu$ long. After Kofoid.

c. Goniaulax fragilis (Schütt), living.

Barents Sea. After Wulff, 1916.

open. Surface faintly marked by lines and a delicate tracery; several prominent pores in certain places. Length $30 \mu$.

Baltic, North Sea, North Atlantic, waters round Greenland. A species looking like this one in chains of two has been seen in Plymouth Sound, but the plates were not elucidated.

\section{Sub-genus Steiniella.}

Laterally compressed, apical closing platelet carried over to the dorsal face of epitheca. Large rotund body with very fragile theca, 3 or 4 apicals and no anterior intercalary. 


\section{Goniaulax fragilis (Schütt) (1896).}

Kofoid, $1911 b$.

Text-figure $31 \mathrm{~b}$ and $31 \mathrm{c}$.

Steiniella fragilis Paulsen, 1908, pp. 32-33.

Body roundish oval, no apical horn. Girdle displaced about 3 girdle widths, without overhang. No spines. Theca extremely thin. Plate formula $3^{\prime} 0 a 6^{\prime \prime} 6^{\prime \prime \prime} 1 p 1^{\prime \prime \prime \prime}$. Surface nearly smooth, faint longitudinal markings. Yellow chromatophores. Length $82-105 \mu$.

California, Gulf Stream, waters North of Scotland, Barents Sea, Atlantic, Adriatic, Naples.

Wulff's specimens from the Barents Sea look very much like some species of Gymnodinium, the plates being inconspicuous in the living organism.

\section{Genus Diplopsalis Bergh (1882).}

This genus has been the subject of much discussion, as there are several forms with various arrangements of plates which have been attributed to it. For a discussion of these see Lebour (1922), to which paper all synonymy of these genera leading up to Peridinium has been referred.

Cell lens-shaped, with a left longitudinal list fairly conspicuous. Plate formula $3^{\prime} 1 a 6^{\prime \prime} 5^{\prime \prime \prime} 1^{\prime \prime \prime \prime}$. The plate here called the anterior intercalary may be a displaced apical. Apical pore present. Marine and in relict seas.

One species :-D. lenticula Bergh.

\section{Diplopsalis lenticula Bergh (1882).}

Plate XV, figures 1a-1e.

Lebour, 1922.

Not Paulsen, 1908, except his reference to Stein's figure (Plate 1X, figure 1), and his figure of the epitheca which is taken from that figure.

Epi- and hypothecae nearly equal. Girdle almost central, not displaced. The three large apical plates meet in the centre, the anterior intercalary nearly pushing out the third and fourth precingulars. Girdle lists with fine spines. Longitudinal furrow reaching nearly to the centre of the hypotheca, the left longitudinal list very large and conspicuous, serrated at the edge. Plasma pale pink. Large pusule. Probably saprophytic. Theca finely punctuated. Reproduction by spores (usually two) which emerge from the theca by its opening at the girdle. Length $29-34 \mu$; breadth $33-40 \mu$.

Skaggerak (?), Northumberland coast, Clyde, English Channel (Plymouth), coast of Brittany, Lake of Thau and Mediterranean. 
This is presumably the original form of Bergh from the Skaggerak, but apparently it has never been rediscovered there, and others regard the original to be Peridiniopsis asymmetrica or Diplopeltopsis minor. Pavillard $(1912,1913,1916)$ was the first to suggest it was the present species.

Ostenfeld's D. caspica (1901, 1908), from the Caspian and the Aral Seas, is closely related to this species, but with a more conical apex. His D. pillula (1908, and Paulsen, 1908) and Mangin's D. minima (1911) do not agree with the present genus in their plate structure. D. pillula, from the Aral Sea, plate formula $3^{\prime} 0 a 5^{\prime \prime} 5^{\prime \prime \prime} 2^{\prime \prime \prime \prime}$, is recorded also from the Zuider Zee by Paulsen (1908), but he refers to a figure of Van Breeman (1905) which is not sufficiently described for one to be sure of its belonging to this species.

D. minima Mangin, from the coast of Brittany, has the epitheca very like Diplopsalis, but with only 5 precingulars, 1 anterior intercalary and 2 antapicals. Plate formula $3^{\prime} 1 a 5^{\prime \prime} 5^{\prime \prime \prime} 2^{\prime \prime \prime \prime}$. It thus appears to belong to a new genus.

D. saecularis Murray and Whitting (1889 and Paulsen, 1908, p. 36) is not sufficiently known as regards plate structure to be assigned to any definite position. It is almost certainly not a Diplopsalis.

\section{Genus Peridiniopsis Lemmermann (1904).}

Lebour, 1922.

Cell with plates. Plate formula $3^{\prime} 1-2 a 6^{\prime \prime} 5^{\prime \prime \prime} 2^{\prime \prime \prime \prime}$. Round, conical or lenticular. Like Diplopsalis, but with two antapicals, and in the subgenus Diplopelta with a second small anterior intercalary plate. The large anterior intercalary may, however, be a displaced apical. Marine and fresh-water. This genus was founded by Lemmermann (1904) for the fresh-water species $P$. Borgei. Peridinium Penardii Lemm. (Schilling, 1913 , p. 41), also a fresh-water species, is a Peridiniopsis.

\section{Sub-genus I. Peridiniopsis Lebour (1922).}

Plate formula $3^{\prime} 1 a 6^{\prime \prime} 5^{\prime \prime \prime} 2^{\prime \prime \prime \prime}$.

To this sub-genus belong Peridiniopsis Borgei, P. Penardii and $P$. rotunda Lebour.

\section{Sub-genus II. Diplopelta Jörgensen (1913).}

Plate formula $3^{\prime} 2 a 6^{\prime \prime} 5^{\prime \prime \prime} 2^{\prime \prime \prime \prime}$.

To this sub-genus belongs Peridiniopsis asymmetrica Mangin. 


\section{Sub-genus Peridiniopsis.}

\section{Peridiniopsis rotunda Lebour (1922).}

Plate XV, figures $4 \mathrm{a}-4 \mathrm{e}$.

Cell globular, apical pore on a small prominence. Girdle central, not displaced, provided with conspicuous lists strengthened by minute spines. First apical pentagonal and in shape like that of the section Metaperidinium in the genus Peridinium (see below), the anterior intercalary coming round to meet it on the left side. Longitudinal furrow not reaching to the centre of the hypotheca, provided with a conspicuous wing-like list on the left. Plasma pinkish or almost colourless. Conspicuous pusule. Probably saprophytic. Theca finely punctuated. Diameter of cell 22-28 $\mu$.

Plymouth Sound.

The precingular plates of this species were so difficult to see that it was not quite, although almost, certain that there were 6 . It is placed in this genus on that assumption.

Fauré-Fremiet's Peridinium inaequale (1908) is possibly a Peridiniopsis, but there are antapical spines present, which is unusual in this genus.

\section{Sub-genus Diplopelta Jörgensen (1913).}

Lebour, 1922.

Genus Diplopelta Jörgensen (1913).

Peridiniopsis asymmetrica Mangin (1913).

Plate XV, figures 3a-3e.

Lebour, 1922.

Diplopsalis lenticula Paulsen, 1908; Nordisches Plankton (in part).

Cell lens-shaped, apical pore on a small prominence. Girdle central, not displaced, provided with lists without strengthening spines. First apical of the Orthoperidinium type (see below). Large anterior intercalary nearly joining the apex (perhaps an apical), the small one diamondshaped and wedged in between this and the precingulars 2 and 3 . Longitudinal furrow not nearly reaching to the centre of the hypotheca, provided with a conspicuous but short wing-like left list. Plasma pink. Large pusule. Probably saprophytic. Theca finely punctate. Reproduction by spores as in Diplopsalis. Diameter $50-89 \mu$, usually about $80 \mu$ or more.

Very common in Northern waters as well as elsewhere. North Sea, Swedish and Norwegian Seas, Clyde, Irish Sea, Atlantic Ocean, English Channel, Flemish and Brittany coasts, Baltic, Mediterranean, Boston Straits, Celebes, and Indian Seas.

This is the largest and best known of the three species which have been 
called Diplopsalis lenticula Bergh, the other two being the Diplopsalis lenticula described above, and Diplopeltopsis minor (Paulsen). Peridiniopsis asymmetrica and Diplopeltopsis minor together are recorded as Diplopsalis lenticula in the International records. It is not the case, however, as suggested by Paulsen (1912), that only D. minor occurs at Plymouth. All three species occur there, the present one, $P$. asymmetrica, being found further out to sea than the others, but also commonly coming into the Sound.

\section{Genus Diplopeltopsis Pavillard (1913).}

Cell lens-shaped. Plate formula $3^{\prime} 2 a 7^{\prime \prime \prime} 5^{\prime \prime \prime} 1^{\prime \prime \prime \prime}$, or the large intercalary may be an apical. Like Diplopelta, but with 7 precingulars and 1 antapical. Marine and estuarine.

One species :-Diplopeltopsis minor Lebour.

\section{Diplopeltopsis minor Lebour (1922).}

Plate XV, figures 2a-2e.

Diplopsalis lenticula, forma minor Paulsen, 1908; Nordisches Plankton, p. 36.

Epitheca and hypotheca nearly equal. Girdle central, not displaced, provided with lists strengthened by fine spines. Longitudinal furrow not reaching to the centre of the hypotheca, with a conspicuous but narrow wing-like list on the left. Small anterior intercalary diamond-shaped and occupying a position similar to that in $P$. asymmetrica. There is only one antapical plate. Plasma pinkish. Large pusule. Probably saprophytic. Theca very finely punctuate. Diameter $28-56 \mu$, usually over $40 \mu$.

Zuider Zee, Western Baltic, Skaggerak, Kattegat, Belt Sea, fjord in the Faroes, coast of Brittany, English Channel, Barents and Kara Seas.

At Plymouth it is found in the estuaries as well as the Sound and outside.

\section{Genus Entzia Lebour (1922).}

Plate formula $4^{\prime} 1-2 a 7^{\prime \prime} 5^{\prime \prime \prime} 1^{\prime \prime \prime \prime}$. Apical pore present. Differs from Peridinium, sub-genus Archaeperidinium, in having only one antapical plate and sometimes only one anterior intercalary.

One species:-Entzia acuta (Apstein).

Entzia acuta (Apstein).

Text-figure 32 .

Lebour, 1922.

Peridinium latum Paulsen, 1908; Nordisches Plankton, p. 41.

Diplopsalis acuta (Apstein), Entz. fil., 1906 ; Schilling, 1913.

Cell roundish, epitheca conical, slightly larger than the hypotheca, 
which is rounded. Girdle not displaced. Longitudinal furrow reaching almost to the centre of the hypotheca, with a wing-like list on the left. Intercalary striae broad or narrow. First apical of the Orthoperidinium type. Dorsal plates (according to Entz. fil., 1906) either with one large anterior intercalary, or with this divided into two equal parts as in

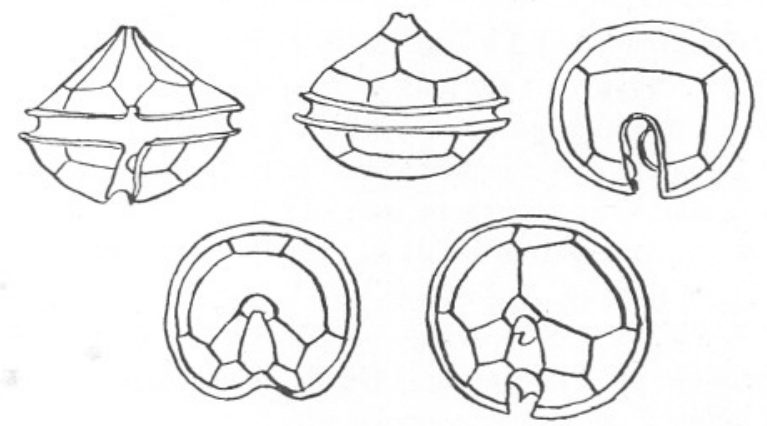

FIG. 32. Entzia acuta (Apstein).

$\times 350$, Balaton Lake, Hungary. From Schilling, 1913 ; after Entz fil, 1906.

ventral, dorsal, hypotheca and epitheca.

Archaeperidinium. Plasma chocolate-brown. Length $29-39 \mu$, breadth $26-67 \mu$.

In ponds and lakes. Found by Lemmermann in brackish water. Common in Balaton Lake (Plattensee), Hungary.

The two following genera have the same number of plates typically, but are so different that it is deemed best to keep them separate. Both lead up to Peridinium, sub-genus Archaeperidinium.

\section{Genus Diplopsalopsis Meunier (1910).}

Cell lens-shaped. Plate formula $3^{\prime} 2 a 7^{\prime \prime} 5^{\prime \prime \prime} 2^{\prime \prime \prime \prime}$, or $4^{\prime} 1 a^{\prime \prime \prime} 5^{\prime \prime \prime} 2^{\prime \prime \prime \prime}$ Like Diplopeltopsis, but with 2 antapicals. Marine.

One species :-Diplopsalopsis orbicularis (Paulsen).

Diplopsalopsis orbicularis (Paulsen).

Lebour, 1922.

Plate XVI, figures 1a-1e.

Peridinium orbiculare Paulsen, 1908; Nordisches Plankton, p. 42.

Cell globular or lens-shaped. Apical horn hardly apparent. Girdle central, not displaced. Lists without spines (?). Longitudinal groove not reaching to the centre of the hypotheca, provided with a large wing- 
like list on the left. Apical plates as in Orthoperidinium. Plasma pinkish. Diameter $40-46 \mu$. Neritic.

North Sea, Danish waters, Iceland, English Channel. A specimen with a very small extra intercalary was found at Plymouth.

Genus Kryptoperidinium Lindemann (advance reprint, 1923).

This genus is created by Lindemann in a paper to be published shortly in Botanisches Archiv., an advance reprint of which was kindly sent by him (1923). It includes one species which was formerly known as Glenodinium foliaceum Stein, but is now shown to possess plates, although these are not recognisable at all except by the help of reagents. Cell with a very thin theca, divided into plates which are only discernible with reagents. Plate formula $3^{\prime} 2 a 7^{\prime \prime} 5^{\prime \prime \prime} 2^{\prime \prime \prime \prime}$, but variations may occur in which it is $4^{\prime} 2 a 7^{\prime \prime} 5^{\prime \prime \prime} 2^{\prime \prime \prime \prime}$, which makes it the same as the sub-genus Archaeperidinium of Peridinium. Girdle not displaced. Apical pore present. Longitudinal furrow very small.

Harbours and estuaries.

One species :-K. foliaceum (Stein).

\section{Kryptoperidinium foliaceum (Stein) (1883).}

Plate XVI, figures $2 a-2 f$.

Lindemann, 1923 (advance reprint).

Glenodinium foliaceum Paulsen, 1908; Nordisches Plankton, p. 22.

Cell much flattened dorso-ventrally and twisted on its axis. Convex dorsally, concave ventrally. Epitheca rounded, hypotheca somewhat oblong. Girdle excavated, without lists. Sulcus very narrow, to the left, only reaching about half-way down the hypotheca. Transverse flagellum running nearly round the cell, longitudinal flagellum about the length of the cell. Red stigma near flagellar pore; many small plate-like greenish brown chromatophores. Apical pore small but distinct. Theca smooth, thin; plates showing up with reagents. In all those from Plymouth there were 3 apicals and a very large seventh precingular; but Lindemann has found several variations, one of which has 4 apicals, although the arrangement in the Plymouth form he also finds the commonest. I have thus taken this to be the typical arrangement. A small triangular plate dividing the ends of the girdle apparently belongs to the ventral area. Length $28-33 \mu$.

Baltic; harbour of Rostock, Mecklenburg; Yealm estuary, near Plymouth. Occurs in enormous quantities, usually colouring the water a brownish green.

It is evident that here we have a species with variable plates leading up to Peridinium. 


\section{Genus Peridinium Ehrenberg (1840).}

Cell more or less top-shaped. Apical pore typically present. Often an apical horn. Plate formula $4^{\prime} 2-3 a 7^{\prime \prime} 5^{\prime \prime \prime} 2^{\prime \prime \prime \prime}$. Girdle usually in three parts. Marine and fresh-water.

Two sub-genera are here recognised :-

1. Archaeperidinium Jörgensen, 1913 ; Lebour, 1922. Plate formula $4^{\prime} 2 a 7^{\prime \prime} 5^{\prime \prime \prime} 2^{\prime \prime \prime \prime}$.

2. Peridinium proper Lebour, 1922. Plate formula $4^{\prime} 3 a 7^{\prime \prime} 5^{\prime \prime \prime} 2^{\prime \prime \prime \prime}$. The subdivision of the genus Peridinium into Protoperidinium and Euperidinium (Paulsen, 1908) was important in that it divided the righthanded forms from the left-handed forms, but very little prominence was given to the arrangement of the plates, so that with further investigation it was found that species closely related in their plate structure were far apart in this classification. Also the division into hollow-horned and solid-spined species does not hold good, although the majority of hollow-horned forms belong to Euperidinium, and solid-spined to Protoperidinium. The girdle also is often almost circular in both groups.

A much more satisfactory classification is brought forward by Jörgensen (1913), who divides Peridinium in the first place according to the arrangement and form of the first apical plate, and secondly (excluding Archaeperidinium) according to the arrangement of the dorsal epithecal plates.

The genus Peridinium is thus divided into two groups, the first Orthoperidinium with a more or less diamond-shaped first apical which touches the first and seventh precingulars, and the second and fourth apicals (Text-figure 33a).

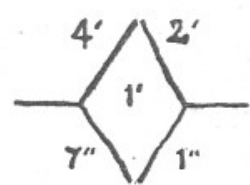

a.

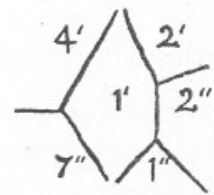

b

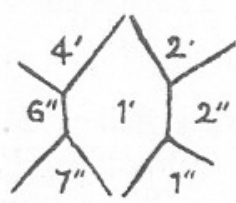

C

FIG. 33. Diagram showing arrangement of first apical plate in
a. Orthoperidinium.
$b$. Metaperidinium.
c. Paraperidinium.

To this group belongs the sub-genus Archaeperidinium, all the lefthanded species of Peridinium proper and many that have an almost circular girdle (mostly belonging to Euperidinium). Diplopsalis and its relatives are also of the Orthoperidinium type (with the exception of one 
or two aberrant forms, and these have not the structure of the Metaperidinium group) and all the fresh-water species of Peridinium so far known.

The second group, Metaperidinium, has the first apical pentagonal or hexagonal touching the first, second and seventh precingulars, sometimes also the sixth, and the second and fourth apicals. When it touches the sixth precingular the plate is hexagonal, and the term Paraperidinium has been given to this type by Jörgensen (Text-figures $33 \mathrm{~b}$ and $33 \mathrm{c}$ ) which is regarded as a section. To Metaperidinium belong all the right-handed species of Peridinium and many with almost circular girdles, the majority having solid spines, a few, however, having hollow horns. This group coincides to a great extent, but not entirely, with Gran's Protoperidinium.

The Orthoperidinium and Metaperidinium groups are again divided into sections according to the arrangement of the dorsal epithecal plates. These are described under the two groups.

Species :-

\section{Sub-genus Archaeperidinium.}

Peridinium monospinum Paulsen, $P$. avellana Meunier, $P$. Thorianum Paulsen, $P$. excentricum Paulsen, P. triqueta (Stein).

\section{Sub-genus Peridinium.}

Group Orthoperidinium.

Section Conica.

Peridinium conicum (Gran), P. pentagonum Gran, P. conicoides Paulsen, P. Leonis Pavillard, P. Willei Huitfeld-Kaas, P. Faeröense Paulsen, P. trochoideum Stein (Lemm.), P. achromaticum Levander, P. subinerme Paulsen, $P$. Anthonyi Fauré-Fremiet, $P$. fimbriatum Meunier, $P$. nudum Meunier, $P$. divaricatum Meunier, $P$. tabulatum (Ehr.), P. elongatum Meunier, P. Yserense Meunier.

\section{Section Oceanica.}

P. depressum Bailey, P. saltans Meunier, P. oceanicum Vanhöffen, $P$. oblongum (Aurivillius), $P$. obtusum Karsten, $P$. bulla Meunier, $P$. verrucosum Meunier, P. robustum Meunier.

\section{Section Tabulata.}

P. claudicans Paulsen, P. punctulatum Paulsen.

\section{Group Metaperidinium.}

\section{Section Pyriformua.}

P. Granii Ostenfeld, P. mite Pavillard, P. Steinii Jörgensen, P. ovatum (Pouchet), P. pyriforme Paulsen. 


\section{Section Divergens.}

$P$. divergens Ehrenberg, $P$. curtipes Jörgensen.

\section{Section Humilia.}

P.globulus Stein, P. cerasus Paulsen, (?) P. roseum Paulsen, P. brevipes Paulsen, $P$. varicans Paulsen, $P$. breve Paulsen, $P$. decipiens Jörgensen, P. monacanthus Broch, P. sub-curvipes Lebour.

\section{Section Paraperidinium.}

$P$. pallidum Ostenfeld, $P$. pellucidum (Bergh) Schütt, $P$. curvipes Ostenfeld, $P$. islandicum Paulsen, $P$. diabolus Cleve.

Incerte sed:s:-P. macrospinum Mangin, P. Balticum (Levander) Lemmermann.

\section{Sub-genus Archaeperidinium Lebour (1922).}

Archaeperidinium Jörgensen, 1913.

Plate formula $4^{\prime} 2 a^{\prime \prime} 7^{\prime \prime} 5^{\prime \prime \prime} 2^{\prime \prime \prime \prime}$.

Orthoperidinium group. The two anterior intercalaries either meet in the dorsal region (all known marine forms), or are separated by the fourth precingular (several fresh-water forms).

\section{Peridinium monospinum Paulsen (1907).}

Plate XVI, figures $3 \mathrm{a}-3 \mathrm{~h}$.

Paulsen, 1908; Nordisches Plankton, p. 41. Archaeperidinium monospinum Jörgensen, 1913.

,

Pavillard, 1913.

Peridinium aspinum Meunier, 1919.

Peridinium (Archaeperidinium) monospinum Lebour, 1922.

Cell globular, with a conspicuous, but low, apical horn. Girdle not displaced, with narrow lists not supported by spines. Longitudinal furrow reaching nearly to the centre of the hypotheca and expanding posteriorly, provided on both sides with lists, the left wing-like and conspicuous with a spine at its broadest part; two other small spines are sometimes apparent below. Broad intercalary striae sometimes present. Theca with fine pores far apart. Colourless. Reproduction by spore formation, a single spore being liberated by the theca opening at the girdle. Diameter of cell $40-56 \mu$.

North Sea, English Channel, Brittany coast ; common at Plymouth

This is very like Kofoid's P. minutum (1907) from San Diego, California. Fauré-Fremiet (1908) describes a variety of P. minutum (var. Tahihouensis) from La Hougue which apparently belongs to the present species, 
but has an irregularly shaped first apical and a small extra precingular at the right.

Peridinium avellana Meunier (1919).

Plate XVII, figures la-1f.

Cell somewhat nut-shaped, irregular. No apical horn. Girdle conspicuously left-handed, excavated, striated, with narrow lists not supported by spines. Longitudinal furrow reaching nearly to the middle of the hypotheca, expanding posteriorly, without conspicuous lists. Broad intercalary striae sometimes present. Theca thickly covered with pores and striae. First apical not reaching to the apex, the fourth apical coming over ventrally like a hood. Colour greenish yellow or colourless. Diameter of cell $30-42 \mu$.

Plymouth Sound and outside. Flemish coast in littoral and brackish localities.

Peridinium Thorianum Paulsen (1905).

Plate XVII, figures 2a-2f.

Paulsen, 1908; Nordisches Plankton, p. 62.

Meunier, 1910.

Jörgensen, 1913.

Properidinium Thorianum Meunier, 1919.

Peridinium (Archaeperidinium) Thorianum Lebour, 1922.

Cell somewhat rhombic in ventral view, with convex sides. Girdle left-handed, striated, excavated, with inconspicuous lists not supported by spines. Longitudinai furrow straight and narrow, with very inconspicuous lists, not reaching to the centre of the hypotheca, usually without spines. Nearly circular in apical view. Large apical pore on the first and third apicals. Theca covered with large papillae more or less running into one another to form striae. Intercalary bands sometimes broad. Colour pale yellow. Diameter of cell 56-70 $\mu$.

Iceland, Faroes, Skaggerak, Barents Sea, North Sea, English Channel, Flemish coast.

Peridinium excentricum Paulsen (1907).

Plate XVIII, figures 1a-1d.

Paulsen, 1908; Nordisches Plankton, p. 51.

Jörgensen, 1913.

Pavillard, 1916.

Meunier, 1919.

Peridinium Perrieri Fauré-Fremiet, 1909.

Peridinium (Archaeperidinium) excentricum Lebour, 1922.

Cell depressed, very much obliquely twisted so that the left side of the hypotheca is larger than the right and the right side longer than the left. 
Apex conical, excentric ; anterior intercalaries very dissimilar, the first small, the second very large and reaching beyond the centre of the dorsal surface. Girdle not displaced, excavated, provided with lists which are supported by fine spines. Longitudinal furrow deep, oblique, reaching beyond the centre of the hypotheca, with narrow lists. Hypotheca projecting on the left in an antapical process. Colour pinkish. Diameter of cell $45-60 \mu$.

Northern Seas, Skaggerak, English Channel, Flemish and Brittany coasts, Mediterranean.

Pavillard (1916) was the first to notice there were only two anterior intercalary plates. On this account it is placed in the sub-genus Archaeperidinium.

\section{Peridinium triqueta (Stein) (1883). \\ Plate XVIII, figures 2a-2f.}

Heterocapsa triqueta Paulsen, 1908; Nordisches Plankton, p. 26. Properidinium heterocapsa Meunier, 1919.

Cell elongated, irregular, the hypotheca ending in a somewhat oblique point. No apical spine. Apical pore only sometimes present (see Lindemann, advance reprint, 1923). Girdle left-handed, excavated, with very inconspicuous lists. Longitudinal furrow not reaching to the end of the hypotheca and without lists. First apical separated from the girdle by the first and seventh precingulars (the seventh regarded by Lindemann and others as part of the ventral area). Intercalary striae sometimes broad. Fourth apical projecting ventrally. Many small greenish brown chromatophores. Length $16-30 \mu$. Reproduction by spore formation, the theca opening at the girdle to allow one spore to escape which divides into two obliquely, each portion becoming a new individual and forming a theca before separation. Neritic, often in estuaries. Common.

Atlantic, Baltic, Bosphorus, Plymouth Sound and estuaries near, Brittany coast, Flemish Sea, Nieuport.

We owe to Meunier (1919) the realisation of the true relationship of this species. Dr. E. J. Allen, of the Plymouth Laboratory of the Marine Biological Association of the United Kingdom, obtained a flourishing pure culture from water taken from the Sound. From this the reproduction and division were studied.

The fresh-water forms with two anterior intercalaries either have their plates touching as in the marine forms, e.g. P. apiculata (Ehrbg.), or have them separated by the fourth precingular, which touches the fourth apical, e.g. P. umbonatum Stein, P. inaequale Lemm., P.pusillum (Penard), P. marchicum Lemm., P. inconspicuum Lemm. (see Schilling, 1913). These have not been seen by the writer. Peridinium achromaticum 
Lemm. (Paulsen, 1908, p. 62), although figured by Levander with only two, has in the marine form three anterior intercalaries, and belongs to Peridinium proper. It is possible, however, that here two separate species are involved.

\section{Sub-genus Peridinium.}

Peridinium proper, with three anterior intercalaries, includes such a large number of species that subdivision is again necessary. Jörgensen (1913) has helped very materially by dividing them according to the arrangement of the dorsal plates, taking the second anterior intercalary and its relations with its neighbours. Thus it may be touching the third, fourth and fifth precingulars, or it may only touch two, the third and fourth or the fourth and fifth, or it may only touch the fourth. These arrangements occur in both Orthoperidinium and Metaperidinium groups. Jörgensen has named these sections of Orthoperidinium Conica, Tabulata and Oceanica respectively. In Metaperidinium he has named them Paraperidinium, Pyriformia and Humilia, with an extra section Divergens (Text-figure 34).

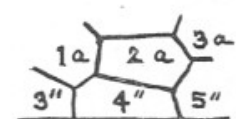

a

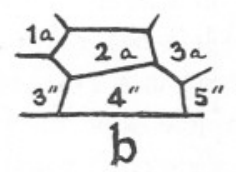

b

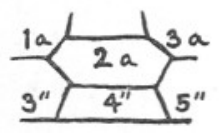

C

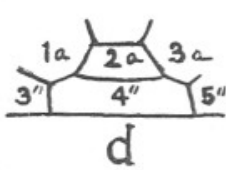

FIG. 34. Diagram showing arrangement of the second anterior intercalary plate in the sections of Orthoperidinium and Metaperidinium.

$a$ and $b$. Orthoperidinium Tabulata, Metaperidinium Pyriformia.

c. Orthoperidinium Conica, Metaperidinium Paraperidinium.

d. Orthoperidinium Oceanica, Metaperidinium Divergens and Humilia.

Although the more recent researches show that the arrangement of these dorsal plates is not always constant (Barrows, Lindemann and others), still one arrangement is almost always typical for the species, and it is only in a few cases that the plates vary so much within the species that one is in difficulty in which section to place it. The division into sections according to the dorsal epithecal plates has been found so useful in classifying the enormous genus Peridinium that, although acknowledging that the plates are sometimes variable, it has been thought advisable to retain it, noting those cases in which variation is known. Perhaps the most important recent observation on the variability of the plates within a species is one made by Miss S. Marshall, who kindly allows me to print it, on Peridinium ovatum from Millport on the Clyde. This species she found varies enormously in that the majority had the dorsal plates as in the section Humilia (which agrees with the earlier drawings 
and statements of Broch, Jörgensen and others). In many specimens the median dorsal plate (2a) was asymmetrical, but a certain number were as in the section Pyriformia, which arrangement was found by myself in all specimens examined from Plymouth, also from India and other localities and regarded as typical (1923). Later I examined some of Miss Marshall's specimens and found both forms as she states. Which, then, is to be regarded as the typical structure? Since I have found it to be as in the section Pyriformia in so many specimens from various localities, and it is also thus figured by Meunier (1919), it seems to be advisable to keep it in this section, stating that it is very variable and may frequently be as in the section Humilia. The classification into these sections is merely for convenience, and it is fully realised that the arrangement is a natural and mechanical effect of a splitting up into plates in a more or less globular organism, so many arrangements being possible and nearly all of these being found to occur in the dinoflagellate theca.

\section{Group Orthoperidinium.}

\section{Section Conica.}

Second anterior intercalary plate touching precingulars 3,4 and 5 .

\section{Peridinium conicum (Gran) (1900). Plate XIX, figures 1a-1d.}

Paulsen, 1908; Nordisches Plankton, pp. 58-59.

Peridinium acutangulum (Lemm.) Jörgensen, 1913.

Cell nearly symmetrical, flattened dorso-ventrally. Epitheca triangular in ventral view, with straight or slightly convex sides. Hypotheca and epitheca sub-equal. Hypotheca with two hollow antapical horns full of protoplasm, without spines. Girdle almost circular, slightly left-handed, excavated, supported by narrow lists. Intercalary striae often broad, especially on the sutures between the second and third apicals and the second and sixth precingulars ; these form two conspicuous ridges characteristic of this species and $P$. pentagonum. Longitudinal furrow reaching to beyond the centre of the hypotheca, with very inconspicuous lists. Theca finely reticulated. Colour pinkish to colourless, probably saprophytic. Diameter of cell $70-76 \mu$. Neritic.

Baltic, English Channel, coast of Brittany, Flemish coast, Mediterranean, Adriatic, Bosphorus, Golden Horn. Very common at Plymouth both inside and outside the Sound.

Meunier (1919) includes several species under this name, and this is probably the same in many other cases. In 1910 he describes a variety bilobata with a very deep antapical depression. 


\section{Peridinium pentagonum Gran (1902).}

Plate XX, figures 1a-1e.

Paulsen, 1908; Nordisches Plankton, p. 59.

Peridinium sinwosum (Lemm.) Jörgensen, 1913.

Cell asymmetrical, pentagonal, with two solid antapical spines. Left side smaller than right. Girdle left-handed, excavated, with fairly broad lists. Longitudinal furrow not reaching to the centre of the hypotheca, with indistinct lists. Intercalary striae often broad, the two ridges as in the preceding species distinct but closer together. Colour pinkish. Probably saprophytic. Diameter of cell $75-100 \mu$. Neritic.

Northern Seas, English Channel, Brittany and Flemish coasts. Common at Plymouth.

Peridinium conicoides Paulsen (1905). Plate XX, figures 2a-2d.

Paulsen, 1908; Nordisches Plankton, pp. 58-59.

Cell in ventral view somewhat rhombic, with weakly convex sides. Girdle almost circular, excavated, with finely broad lists. Hypotheca ending in two short hollow horns. Longitudinal furrow broadening posteriorly, on the left making a twist just below the girdle, sometimes with two small spines near it. Outline from above and below nearly circular. Cell contents pale yellow. Diameter of cell $45-60 \mu$. Neritic, Arctic species.

Iceland, Greenland, Skaggerak, Kattegat, English Channel (Plymouth). Fauré-Fremiet's Peridinium sp. (1908, p. 215) probably belongs to this species, although the longitudinal furrow does not quite agree.

\section{Peridinium Leonis Pavillard (1916).}

Plate XXI, figures 1a-1d.

Peridinium saltans Pavillard, 1915.

Peridinium conicum Meunier, 1919 (in part).

Differs from $P$. pentagonum in having a profound depression between the posterior horns which bear solid spines. There is a distinct difference also in the suture lines in front and behind the plates, $2^{\prime} 2^{\prime \prime}$ and $4^{\prime} 6^{\prime \prime}$. The back line in particular makes a very distinct division into dorsal and ventral portions in $P$. pentagonum and $P$. conicum, whilst in $P$. Leonis this division is not apparent, the line being a zigzag. Outline much rounder in $P$. Leonis than in the other two. Intercalary striae may be broad. Girdle left-handed, excavated, with fairly broad lists with fine supporting spines. Longitudinal furrow reaching nearly to the centre of the hypotheca, with faint spines. Theca reticulated, usually spiny, some- 
times ridged. Colour pinkish, probably saprophytic. Cell diameter $65-95 \mu$. Neritic, very common.

Plymouth, Mediterranean, Adriatic. Probably occurs abundantly elsewhere, but has been confused with $P$. pentagonum and conicum. FauréFremiet's $P$. typus (1908) may belong to this species, although no spines are figured.

\section{Peridinium Willei Huitfeld-Kaas (1900).}

Plate XXI, figures 2a-2d.

Paulsen, 1908; Nordisches Plankton, p. 66.

Cell flattened dorso-ventrally, strongly armoured. Epitheca rounded, longer than hypotheca; no apical horn. Girdle left-handed, excavated, with lists supported by spines. Longitudinal furrow invading the epitheca, with two spines at the hind end. The junction of some of the plates form sharp angles. Intercalary striae usually broad. Theca reticulated. Cell diameter $53-64 \mu$. Fresh-water, sometimes brackish.

One incomplete specimen from the Channel, midway between Plymouth and the coast of France, probably had been carried out from the coast. Flanders, Switzerland, Norway, Bosphorus, English Channel.

\section{Peridinium Faeröense Paulsen (1905). Plate XIX, figures $2 \mathrm{a}-2 \mathrm{~d}$.}

Paulsen, 1908; Nordisches Plankton, pp. 64-65.

Very like $P$. trochoideum, but with a much narrower first apical. Jörgensen (1913) remarks that they may be identical, but the present species is more rotund and without such a conspicuous apex. Otherwise they are very much alike, with brown chromatophores. Cell diameter 16-36 $\mu$. Neritic.

Coast of Iceland and Faroes, English Channel (Plymouth) from near the coast to well outside the Sound. Very common.

This is probably the small round unnamed form figured by FauréFremiet (1909, Pl. XVI, fig. 18) from the coast of Brittany.

\section{Peridinium trochoideum (Stein) Lemm. (1910).}

Plate XIX, figures 3a-3d.

Jörgensen (1913).

Glenodinium trochoideum Paulsen, 1908; Nordisches Plankton, pp. 24-25.

Cell pear-shaped, with a conspicuous apical horn. Hypotheca nearly hemispherical. Girdle left-handed, excavated, with very inconspicuous 
lists. Longitudinal furrow not reaching to the hind end, enlarged posteriorly, with narrow lists. No antapical spines or horns. Cell containing numerous brown disc-like chromatophores, placed so close together that the whole cell appears brown (see figure by Schütt, 1895, Pl. 25). Diameter of cell 23-28 $\mu$. Neritic. Brackish and marine.

Aral Sea, Baltic, west coast of Norway, North Atlantic, Skaggerak, Mediterranean, English Channel (Plymouth). Common.

Lemmermann (1910) first showed that this species was a Peridinium, but he only figures two anterior intercalary plates, whereas there are three in all the specimens examined from Plymouth, bringing it into the section Conica.

Peridinium achromaticum Levander (1902).

Plate XXII, figures la-1g.

Paulsen, 1908; Nordisches Plankton, p. 62.

Schilling, 1913.

Cell somewhat rhombic in ventral view. Sides of epitheca straight or weakly convex. Hypotheca with convex sides. Girdle hardly displaced or slightly left-handed, excavated, provided with narrow lists. Longitudinal furrow broadening behind, sharp at the hind edges so as to appear like spines. Behind these the border is excavated. Outline of epi- and hypothecae roundish. Intercalary striae usually narrow. Plasma colourless and clear. Probably saprophytic. Cell diameter $28-40 \mu$. Neritic, brackish and sea-water.

Finland, Aral Sea, English Channel (Plymouth).

Levander figures this species with only two anterior intercalaries, the fourth precingular dividing them. Schilling (1913) queries there being a dorsal plate (third intercalary), but this is well seen in the Plymouth specimens.

Peridinium subinermé Paulsen (1904).

Plate XXII, figures 2a-2f.

Paulsen, 1908; Nordisches Plankton, pp. 60-61.

Jörgensen, 1913.

Meunier, 1919.

Cell bilaterally symmetrical, in girdle view nearly square, excavated at the hind end. Epitheca with weak convex sides; hypotheca with nearly straight sides. Girdle almost circular, excavated, supported by fine spines. Hind part of the longitudinal furrow lying in a sharp depression whose borders coincide, or nearly so, with the sutures which lie round the furrow and which bear spines. These spines are often lacking in the Arctic specimens, but are usually present in those from the North Sea and the Channel. The Arctic specimens sometimes have spines on the 
border of the furrows. Intercalary striae sometimes broad. Theca usually reticulated and spiny. Diameter of cell $50-60 \mu$.

Boreal or Arctic form, but spreads to the Channel and Brittany coast. South Greenland, Iceland, Skaggerak, Barents and Kara Seas, North Sea. Common at Plymouth.

Peridinium punctulatum Paulsen (1908, p. 61) is considered by Paulsen and Jörgensen (1913) as closely related to P. subinerme, but Meunier (1919) describes and figures the dorsal epithecal plates as irregular, and if they are as he says, the species belongs to the section Tabulata of Orthoperidinium. Paulsen's figure C also seems to show this. Specimens presumably belonging to this species, but not specially examined for plate structure, were found at Plymouth. Pending further evidence, the species is placed in the section Tabulata.

Peridinium Anthonyi Fauré-Fremiet (1908).

Text-figure $35 \mathrm{a}$ (see p. 116).

Cell with conical epitheca; hypotheca rounded, interrupted by the longitudinal furrow, which bears a conspicuous list at the hind end. Girdle slightly left-handed, excavated, striated, with very ineonspicuous lists. Intercalary striae broad between certain plates. Theca reticulated, with the nodules accentuated. The third postcingular is very small. Diameter $46 \mu$.

Known only from the Bay of La Hougue.

\section{Peridinium fimbriatum Meunier (1919).}

Text-figure 35b.

Cell somewhat rhombic in ventral view. Epitheca conical; hypotheca rounded except for the interruption of the longitudinal furrow, which bears a veil-like list at its hind end near the centre of the hypotheca. From this structure the species takes its name. Girdle not displaced, or slightly left-handed, excavated, with fairly wide lists. Diameter of cell ca. $30 \mu$ (calculated).

Known only from the oyster beds at Nieuport and the Yser Canal, Flanders. (Meunier.)

\section{Peridinium nudum Meunier (1919).}

Text-figure 35c.

Cell globular, slightly longer than broad. Girdle slightly left-handed, excavated, with narrow lists, not supported by spines. Longitudinal furrow straight, reaching nearly to the centre of the hypotheca, which is slightly bi-lobed in consequence. No antapical spines. First apical narrow, with straight sides. Cell diameter ca. $25 \mu$ (calculated).

Flemish coast. (Meunier.) 


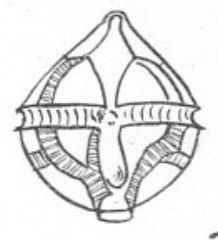

a

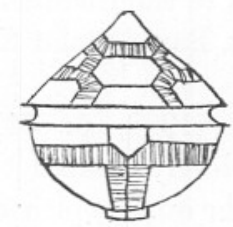

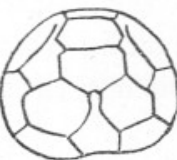

स्मे

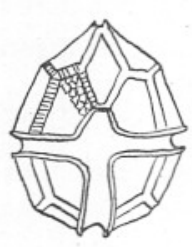

e

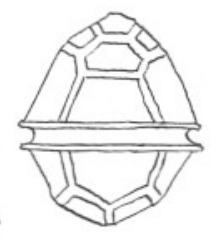

(2)

सह (3)

G

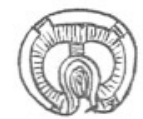

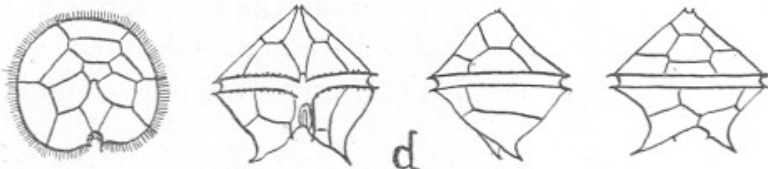
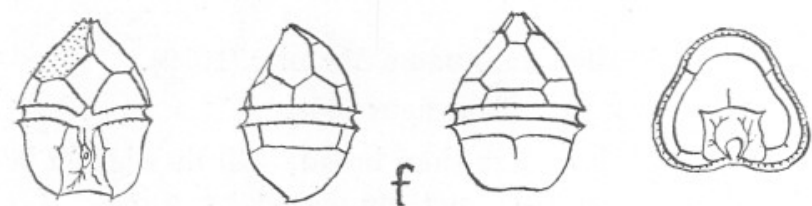

FIG. 35. 
[FIG, 35 .

a. Peridinium Anthonyi Fauré-Fremiet.

$46 \mu$ across, Bay of La Hougue. After Fauré-Fremiet, 1909.

Four drawings : ventral, dorsal, apical and antapical views.

b. Peridinium fimbriatum Meunier.

ca. $30 \mu$ (calculated), Coast of Flanders. After Meunier, 1919.

Five drawings : ventral, dorso-lateral, ventro-lateral, apical and

c. Peridinium nudum Meunier. antapical views.

ca. $25 \mu$ across (calculated), coast of Flanders. After Meunier, 1919. Five drawings : dorsal, side, ventral, apical and antapical views.

d. Peridinium divaricatum Meunier.

$50 \mu$ across (calculated), brackish water, Flanders. After Meunier, 1919. Four drawings : apical, ventral, side and dorsal views.

e. Peridinium tabulatum (Ehrenberg).

$43-45 \mu$ across. After Schilling, 1913.

Four drawings : ventral, dorsal, apical and antapical views.

f. Peridinium elongatum Meunier.

(?) Size, Barents Sea. After Meunier, 1910.

Four drawings : ventral, side, dorsal and antapical views.

g. Peridinium Yserense Meunier.

ca. $36 \mu$ across (calculated), coast of Flanders. After Meunier, 1919.

Five drawings : ventral, side, dorsal, apical and antapical views. 


\section{Peridinium divaricatum Meunier (1919).}

Text-figure 35d (see p. 116).

(?) Peridinium sp. A. Mangin (1913).

Cell nearly bilaterally symmetrical. Girdle slightly left-handed, excavated, with lists supported by fine spines. Hypotheca deeply divided into two divergent hollow horns. Longitudinal furrow with the edges appearing behind as two spines. Cell diameter ca. $50 \mu$ (calculated).

Flanders; West Hinder, (Meunier), (?) Brittany coast, (Mangin).

\section{Peridinium tabulatum (Ehr.). Text-figure 35e.}

Paulsen, 1908; Nordisches Plankton, p. 66.

Cell egg-shaped, flattened dorso-ventrally. Epitheca longer than hypotheca. Girdle left-handed, excavated, with narrow lists. Longitudinal furrow reaching on to the epitheca. No antapical spines. Intercalary striae usually broad. Theca reticulated and with fine spines. Diameter of cell $43-45 \mu$.

Fresh water. Rarely in brackish water in the Northern regions and in Switzerland.

Peridinium elongatum Meunier (1910).

Text-figure $35 f$.

Cell elongated, with rounded sides and conical apex. Hypotheca squarish. Ventral face flattened; dorsal rounded. Transverse section somewhat tri-lobed. Girdle circular, excavated, with narrow lists. Longitudinal furrow very broad, each margin ending in a small spine. Theca covered with very small spines. Size (?).

Barents Sea.

Peridinium Yserense Meunier (1919).

Text-figure 35g.

Cell longer than broad, somewhat flattened ventrally. Girdle lefthanded, excavated, with very narrow lists. Longitudinal furrow reaching to the centre of the hypotheca, with a distinct spine on the left and a fringe-like membrane on the right which seems sometimes to appear as a spine. Diameter of cell ca. $36 \mu$ (calculated).

Brackish water, Flanders, the Yser near Nieuport. (Meunier.)

Peridinium multipunctatum Fauré-Fremiet (1908) is probably an abnormal form, as it seems to have eight precingular plates, but otherwise is like a Peridinium, possibly of the section Conica. 
Peridinium deficiens Meunier (1919) also seem to be abnormal, as it apparently has the first apical fused to the fourth. Meunier found it in numbers on one occasion only on the Flemish coast.

\section{Section Oceanica.}

With the second anterior intercalary touching only the fourth precingular plate.

Peridinium depressum Bailey (1855).

Plate XXIII, figures a-f.

Paulsen, 1908; Nordisches Plankton, p. 53.

Peridinium divergens Meunier, 1910, 1919.

Peridinium divergens Lebour, 1917.

Cell short and broad, flattened obliquely dorso-ventrally. Axis very oblique. Conspicuous apical horn. Girdle slightly left-handed, hardly excavated, with broad membranous lists strengthened with fine spinelike thickenings scattered irregularly. Hypotheca with two long hollow antapical horns, each provided on the inside with a tooth, which is continuous with each side of the furrow. Theca reticulated. Intercalary striae large or small. Plasma pinkish, often with large oil globules. Pusule very large. Probably saprophytic. Diameter of cell 116-144 $\mu$. Length $116-200 \mu$.

Atlantic boreal species. Very common throughout the whole of the Northern area, Atlantic and Indian Oceans, Brittany and Flemish coasts, Mediterranean, Adriatic. Very common at Plymouth.

This is one of the species which has often been called $P$. divergens. As Ehrenberg's original was yellow, it seems more probable that it was the species of the Metaperidinium type, now regarded as divergens. The outlines may be much alike. Many workers have thrown the two together, probably with several other species, without regarding the plate structure. It is now almost universally held that the true $P$. divergens has the structure of a Metaperidinium belonging to the section Divergens (Jörgensen).

P. Kofoidi Fauré-Fremiet (1908) seems to be a variety of this species. Peridinium parallelum Broch (Paulsen, 1908, pp. 53-54) is probably also a variety with the antapical spines solid instead of hollow. In 1912, however, Paulsen regards it as a separate species.

Many so-called species with the same plate structure, but slightly different shape, extent of obliquity, length and form of spines, are probably also varieties of this species. 
Peridinium saltans Meunier (1910).

Text-figure 36a.

Related to $P$. depressum, but much smaller (size not given) and with two very long curved and diverging antapical horns.

West coast of Nova Zembla.

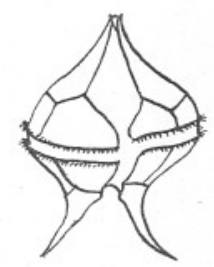

a
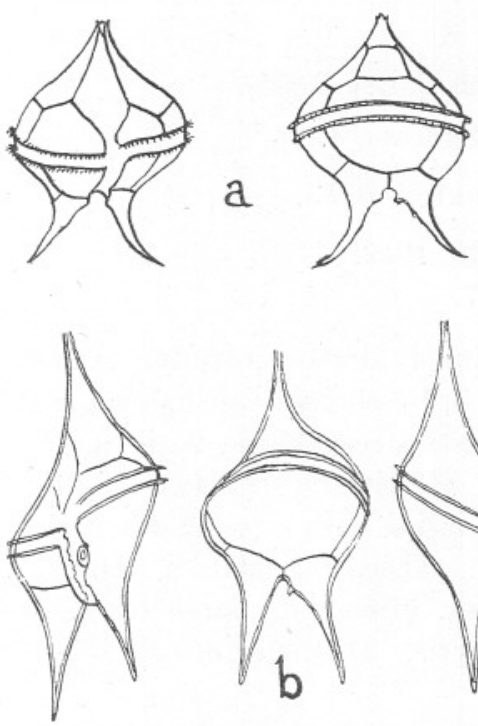
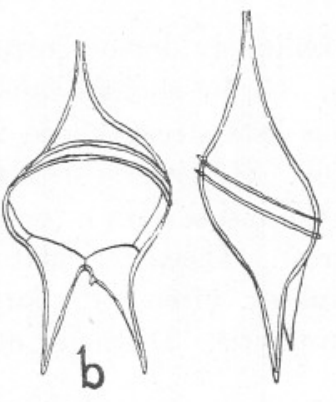

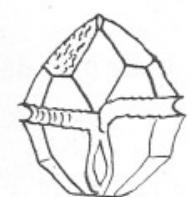

e
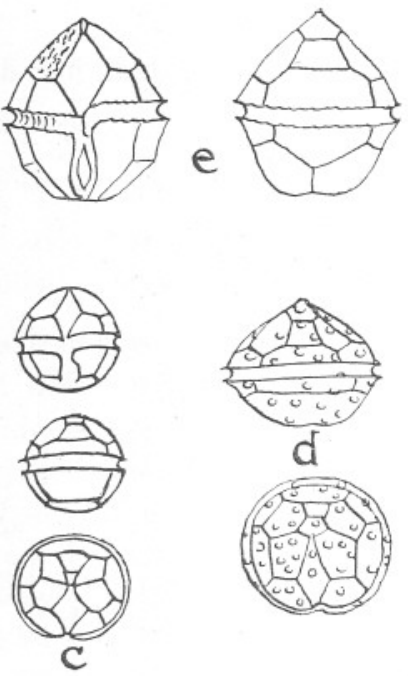

FIG. 36 .

a. Peridinium saltans Meunier.

(?) Length. West coast of Nova Zembla. After Meunier, 1910.

b. Peridinium oceanicum Vanhöffen.

(?) Size. After Paulsen, 1907-8.

c. Peridinium bulla Meunier.

(?) Size. Kara Sea. After Meunier, 1910.

d. Peridinium verrucosum Meunier.

(?) Size. Barents Sea. After Meunier, 1910.

e. Peridinium robustum Meunier.

(?) Size. Barents Sea. After Meunier, 1910.

Peridinium oceanicum Vanhöffen (1897).

Text-figure $36 \mathrm{~b}$.

Paulken, 1908; Nordisches Plankton, pp. 54-55.

Cell much more elongated and oblique than $P$. depressum, with all its processes longer and narrower. Girdle very oblique, left-handed. Plates like $P$. depressum. Length $220-300 \mu$. Oceanic.

Atlantic Ocean. 
This is the $P$. oceanicum var. typica of Broch, who divided the species into a large elongated oceanic form and a smaller shorter neritic one. Jörgensen (1913) and Ostenfeld (1915) both agree in separating the two, which in their plate structure are apparently much alike.

$P$. claudicans, which was regarded by Paulsen as closely related to these, and also by others, is really different in its plate structure, the dorsal plates being arranged as in the section Tabulata (Lebour, 1923).

\section{Peridinium oblongum (Aurivillius).} Plate XXIV, figures 1a-1c.

Peridinium oceanicum var. oblongum Paulsen, 1908; Nordisches Plankton, p. 55.

Probably most of Meunier's figures, 1919.

Like $P$. oceanicum but smaller, with less attenuated horns. Plasma pinkish. Probably saprophytic. Typical length $110-117 \mu$; smaller from Plymouth (from $75 \mu$ ). Neritic.

Skaggerak, Belts, Brittany coast, Flemish coast, Bosphorus, English Channel. Never common.

Lindemann (1923) seems to have confused $P$. oceanicum var. oblonga and $P$. claudicans. As far as I can make out, the former has the dorsal plate arrangement like $P$. depressum and belongs to the Oceanica section; whilst $P$. claudicans has the oblique dorsal plates of the section Tabulata. He believes, however, that the arrangement varies in the species, and figures forms with the arrangement of section Conica, which hitherto has not been found connected with the hollow-horned species of Orthoperidinium.

\section{Peridinium obtusum Karsten (1906). Plate XXIV, figures $2 \mathrm{a}-2 \mathrm{~d}$.}

Fauré-Fremiet, 1908.

Cell like P. Leonis, but rather smaller and more flattened dorso-ventrally. Girdle not displaced, or slightly left-handed, hardly excavated, with lists supported by small spines. Longitudinal furrow reaching well on to the hypotheca, which has two hollow horns with terminal spines. Theca spiny or, according to Fauré-Fremiet, striated. Plasma pinkish. Probably saprophytic. Cell diameter ca. $50 \mu$.

Coast of Brittany, English Channel (Plymouth), Indian Seas (?) (Karsten.)

This is one of the species which seems to have been confused both with $P$. divergens and $P$. conicum and apparently with $P$. leonis. It differs from the first in its first apical, which puts it in the Orthoperidinium 
group, and from the other two by its dorsal plates, which show it to belong to the section Oceanica.

Peridinium bulla Meunier (1910).

Text-figure 36c.

Cell round. Girdle left-handed, excavated; short longitudinal furrow not reaching to the centre of the hypotheca, which is rounded. No apical horn. Theca finely reticulated. Size (?).

Kara Sea, rare. (Meunier.)

Peridinium verrucosum Meunier (1910).

Text-figure 36d.

Cell depressed from above downwards, flattened below. No antapical spines. Theca with large knobs thinly scattered. Very fragile. Size (?).

Barents Sea and Norwegian coast.

\section{Peridinium robustum Meunier (1910).}

Text-figure $36 \mathrm{e}$.

Cell slightly longer than broad, roundish with a flattened hypotheca. Theca thick, solid and strongly sculptured, with a reticulum of sinuous rounded ridges at the bottom of which are circular punctures. Girdle left-handed, excavated. Size (?).

Barents Sea and in the ice region of Northern Seas.

There are apparently no fresh-water species belonging to this section.

\section{Section Tabulata.}

Second anterior intercalary plate touching precingulars 4 and 5 or 3 and 4 .

Jörgensen gives this name to those species of Orthoperidinium having the second anterior intercalary irregularly placed so as to touch only two precingulars, usually 3 and 4 . He refers to it Peridinium tabulatum and other fresh-water species, but no marine forms. Unfortunately $P$. tabulatum itself appears to belong to section Conica, but several fresh-water species do belong to Tabulata. Peridinium claudicans, however, certainly should be placed in it, and from the drawings of Meunier and Paulsen it appears that $P$. punctulatum belongs to this section and not to Conica. If this be correct, it is not such a close relation of $P$. subinerme as was at first sight supposed. 
Peridinium claudicans Paulsen (1907).

Plate XXV, figures 1a-1d.

Paulsen, 1908; Nordisches Plankton, p. 55.

Peridinium sp. Fauré-Fremiet, 1909, fig. 10, p. 224.

Peridinium oceanicum Meunier, 1919.

Shaped like $P$.oblongum, but shorter and broader, with the right apical horn longer than the left, the horns more diverging and the cell contents light yellow to colourless. Girdle left-handed, very slightly excavated, with fairly conspicuous lists. Ventral plates similar to P. oblongum, dorsal plates with the second anterior intercalary touching precingulars 3 and 4 , therefore belonging to the section Tabulata (see Lebour, 1923).

Barrows (1918) gives a figure of this species which he regards as an abnormal form of $P$. claudicans, and this has the arrangement described above. I have examined many specimens from Plymouth and all have this structure. It seems therefore that it is normal. Lindemann (1923) figures the same arrangement in what is probably this species, but which he calls $P$. oceanica var. oblongum. Length 51-96 $\mu$. Neritic.

Zuider Zee and Danish coast, Brittany and Flemish coasts, English Channel, Golden Horn, Bosphorus, coast of California.

\section{Peridinium punctulatum Paulsen (1907).}

Text-figure 37 (see p. 124).

Paulsen, 1908; Nordisches Plankton, p. 61.

Meunier (1919).

Shaped like $P$. subinerme, but without spines on the hypotheca, and the longitudinal furrow narrow. Theca finely punctured and not reticulated. Girdle slightly left-handed, excavated, with lists supported by fine spines. Almost circular in apical view. Cell diameter $40-72 \mu$.

North Sea, English Channel, Flemish coast.

Meunier's and Paulsen's drawings both show the dorsal plates with the second anterior intercalary touching the precingulars 3 and 4. Therefore, although unfortunately the plates in the specimens from Plymouth, which were believed to be this species, were not elucidated, it seems that the species belongs to the section Tabulata and not to Conica.

The specimens figured by Lindemann (1923) as this species seem to be more probably $P$. subinerme.

To this section several fresh-water species belong, including P.tuberosum Meunier (1919), P. stagnale Meunier (1919) Lemm. (Schilling, 1913).

\section{Group Metaperidinium}

First apical plate pentagonal or hexagonal, touching the precingulars 

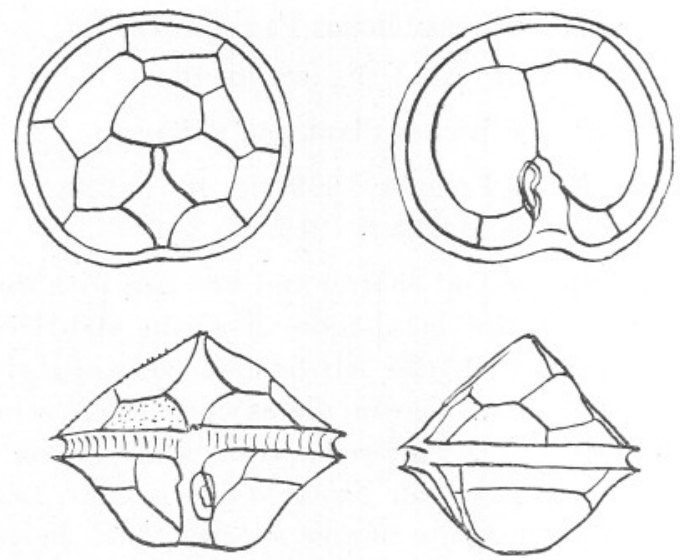

FIG. 37. Peridinium punctulatum Paulsen.

ca. $40 \mu$ broad (calculated), Flemish coast. After Meunier, 1919.

1 and 7 and 2 (or 2 and 6). Girdle usually right-handed. Solid spines usually present at the antapex; rarely hollow horns.

\section{Section Pyriformia.}

First apical pentagonal; second anterior intercalary touching precingulars 3 and 4 or 4 and 5 .

\section{Peridinium Granii Ostenfeld (1906). \\ Plate XXV, figures $2 a-2 b$.}

Paulsen, 1908; Nordisches Plankton, p. 52.

Cell broad. Epitheca with concave or concavo-convex sides. Girdle right-handed, slightly excavated, with lists supported by fine spines. Hypotheca ending in two broad hollow horns, each bearing a spine where the longitudinal furrow ends; the latter is broad with lists. Theca finely reticulated. Length $49-80 \mu$. Neritic.

Boreal species. Skaggerak, Iceland, Murman coast, Bosphorus, English Channel, California.

Barrows (1918) describes a specimen with the dorsal plate reversed, e.g. the second anterior intercalary touching precingulars 4 and 5 , not 3 .

The chief differences between this species and the $P$. mite of Pavillard (1916, p. 37) consist in the shape of the cell and the hollow horns of $P$. Granii compared with the long, solid spines of $P$. mite. Both Paulsen and Pavillard believe they have the original species of Gran (1902, p. 188, fig. 13). Certainly the figure given by Gran is more like $P$. mite, and he describes the spines as "stacheln," which seems to indicate that they 
were solid. $P$. mite occurs at Plymouth, and is certainly different from the present species. I have, however, left Paulsen's species as $P$. Granii until more is known about it, and kept Pavillard's species as $P$. mite.

Peridinium Finlandicum (Paulsen, 1908, p. 51) is probably related to P. Granii, also Jörgensen's P . callosum (1913), which he does not figure but regards as possibly identical with $P$. Finlandicum.

Peridinium mite Pavillard (1916).

Plate XXV, figures $3 a-3 b$.

Cell with rounded sides, an elongated apical horn and two long, slender antapical spines placed far apart. Girdle slightly right-handed, not excavated, with narrow lists supported by spines. Intercalary striae absent or narrow. Length $45-55 \mu$.

Mediterranean, Plymouth Sound.

Peridinium Steinii Jörgensen (1899).

Plate XXV, figures $4 \mathrm{a}-4 \mathrm{~d}$.

Paulsen, 1908; Nordisches Plankton, p. 47.

Peridinium Steinii sub-species Paulseni Kofoid, 1909.

Peridinium Steinii sub-species Paulseni Jörgensen, 1913.

Cell pear-shaped. Hypotheca rounded. Elongated apical horn. Circular outline from above and below. Girdle right-handed or hardly displaced (the latter in the small Plymouth form), not excavated, with lists supported by fine spines. Two long solid antapical spines each with three fins, the left connected with the left list of the longitudinal furrow. Intercalary striae usually broad; second anterior intercalary plate touching precingulars 3 and 4 . Plasma colourless or pale pinkish, rarely yellowish. Length 39-52 $\mu$. Probably an oceanic and a neritic form.

Baltic, Bay of Biscay, Skaggerak, English Channel, Brittany coast, Flemish coast, Golden Horn, Bosphorus, Mediterranean.

Kofoid (1909) in his very beautiful account of Peridinium Steinii, which is the model for any detailed work on a Peridinium species, has divided the species into a Southern form, sub-species Mediterranea, and the present Northern form, sub-species Paulseni. Jörgensen (1913) agrees that the Northern form is the latter sub-species as defined by Kofoid, but also finds a smaller form which he thinks may be identical with a small Peridinium sp. recorded by Vanhöffen from Greenland, but not named. Jörgensen proposes to name this Peridinium Vanhöffeni. As this is neritic and the other oceanic, it is possible that the Plymouth form figured here is this smaller species. Both are regarded here as P. Steinii. 
Peridinium ovatum (Pouchet) (1883).

Plate XXVI, figures 1a-1d.

Paulsen, 1908; Nordisches Plankton, pp. 44-45.

Peridinium lenticulum Fauré-Fremiet, 1908.

Cell flattened from above downwards, lenticular. Girdle right-handed, excavated, with lists supported by spines. Longitudinal furrow broadening behind. Hypotheca with two short solid spines with two wings each. Intercalary striae absent or narrow. Cell contents pink. Breadth 57-84 $\mu$. Oceanic, but a smaller and more neritic form is named $P$. minor by Cleve. Small and large forms are both found commonly in Plymouth Sound and outside.

Very widely distributed:-Norway, Sweden, Atlantic, Mediterranean, Adriatic, North Sea, English Channel, Brittany coast, Indian Seas.

Most of the specimens examined, including some from Madras, have the dorsal epithecal plates asymmetrically arranged as in the section Pyriformia, the second anterior intercalary touching the precingulars 3 and 4 . The species varies, however, in plate arrangement (see p. 110) and may be like those of the section Humilia.

Peridinium pyriforme Paulsen (1907).

Text-figure 38 .

Paulsen, 1908; Nordisches Plankton, p. 46.

Paulsen, 1911.

Cell egg-shaped, thick-walled; epitheca conical, hypotheca rounded. Girdle excavated (?), right-handed, with lists supported by spines. Longitudinal furrow broad, both margins ending in a strong spine with wings,
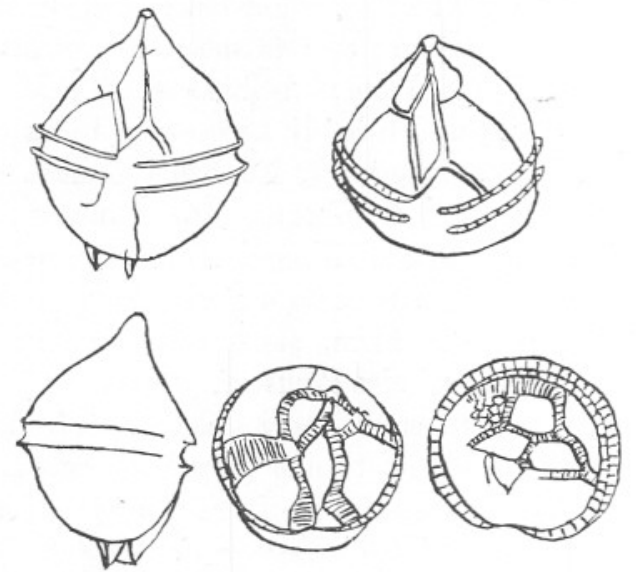

FIG. 38. Peridinium pyriforme Paulsen.

Length $42-43 \mu$, Greenland Seas. After Paulsen, 1911. 
the wing of the left spine continuous with the left list. Theca finely reticulated. Intercalary striae broad. Length $42-70 \mu$. Oceanic.

Faroe-Shetland Channel, Cattegat, East Greenland.

This species is regarded by Paulsen and others as closely related to P. Steinii. Peridinium breve Paulsen (1907), also regarded as closely related, evidently belongs to the section Humitia.

\section{Section Divergens.}

First apical pentagonal; second anterior intercalary touching precingular 4 .

This section Divergens of Jörgensen (1913) embraces the species called by Paulsen $P$. divergens Ehrenberg in a restricted sense and its near neighbours. The plate structure is that of the group Metaperidinium, with symmetrical dorsal epithecal plates in which the second anterior intercalary only touches plate 4 of the precingulars. This is the same dorsal structure as in the section Oceanica of the group Orthoperidinium. A further character of this section, as defined by Jörgensen, is the presence of hollow antapical horns and the almost circular girdle which, however, is usually inclined to be right-handed.

As Jörgensen points out, the species Paulsen designates as $P$. divergens is almost certainly not Ehrenberg's first original form, which was yellow, Paulsen's being pink; Ehrenberg apparently included several species under one name, and he gives no plate structure, but Müller's figure to which he refers may easily be this species (1840). The first figures showing the tabulation are those by Stein (1885), who gives at least three species under one name. Of these, fig. 1 (Plate $\mathrm{X}$ ) is probably $P$. depressum, fig. $7, P$. oceanicum and figs. 2,3 and $4 P$. divergens, as now restricted. The dorsal epithecal plates are not quite accurate, but it is evidently this species. Thus the name divergens, if not strictly applicable to Ehrenberg's first-mentioned species, may and should be used for the species called by Stein the typical form of Peridinium divergens (figs. 2, 3 and 4), which has priority over the name speciosum Jörgensen (1913) and Adriaticum Broch, if the latter be the same species, which is very probable. The name Peridinium divergens may thus be regarded as the correct name for the species described below.

\section{Peridinium divergens Ehrenberg.}

Plate XXVI, figures 2a-2e.

Paulsen, 1908; Nordisches Plankton, p. 56.

Typical form Stein, 1885 (Plate X, figs. 2, 3 and 4).

Peridinium speciosum Jörgensen, 1913.

Cell longer than broad, with conspicuous apical horn and two hollow 
antapical horns. Sides of the epitheca concave or convexo-concave, those of the hypotheca concave. The margins of the longitudinal furrow with more or less developed lists ending in inconspicuous prominences having the appearance of spines. Girdle almost circular, but inclined to be righthanded, excavated slightly, with conspicuous lists supported by spines. Theca strongly reticulated with spines at the junction of the reticulations. Intercalary striae usually broad. Cell contents pinkish. Length $80-84 \mu$; breadth ca. $56 \mu$.

Neritic: Danish and Norwegian Seas, English Channel, Mediterranean (?), Adriatic, Golden Horn, Bosphorus, California. Probably very widely distributed, but hitherto much confused with other species, particularly $P$. crassipes and $P$. depressum.

Peridinium Adriaticum Broch (1910), described from the Adriatic by Broch, and recorded by Pavillard (1916) from the Gulf of Lions, is probably a variety of this species.

Peridinium curtipes Jörgensen (1913).

Text-figure 39.

Peridinium crassipes, Paulsen, 1908 (in part).

Peridinium crassipes Broch, 1908.

Peridinium crassipes Broch, 1910.

This species is separated from Kofoid's $P$. crassipes (1907) by Jörgensen chiefly on account of its shape in the girdle region and its colour, which is yellow instead of pink. Cell short and broad. Epitheca conical, with more or less concave sides ; hypotheca with convexo-concave sides ending
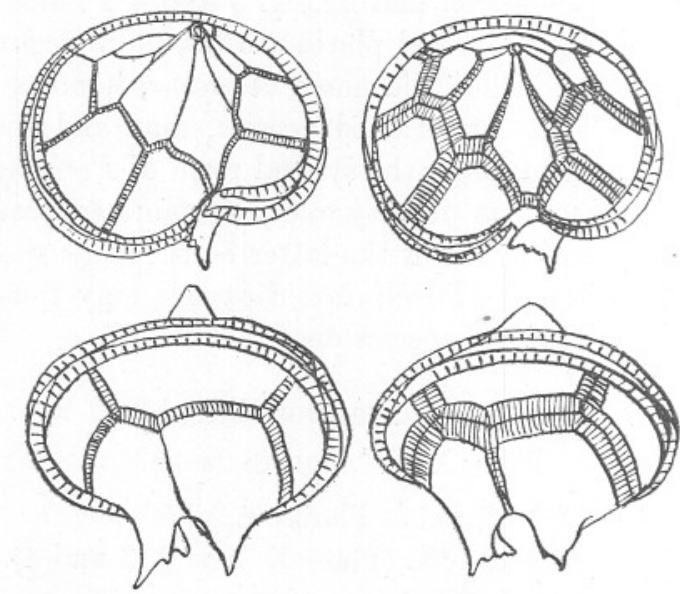

FIG. 39. Peridinium curtipes Jörgensen.

ca. $80 \mu$ broad, Spitzbergen. After Broch, 1910. 
in two thick horns that have conspicuous prominences inside; these latter seem to end in spines which are the continuations of the longitudinal lists. From certain points of view the horns have several projections. Girdle nearly circular, excavated, with lists supported by spines, Longitudinal furrow narrow, with lists. Theca strongly reticulated, with spines at the junction of the reticulations. Intercalary striae usually broad. Cell contents yellow. Length $80-90 \mu$; breadth $67-96 \mu$. Oceanic.

Atlantic, Norwegian and Swedish Seas, Spitzbergen, North Sea, Golden Horn, Bosphorus, English Channel, Brittany coast, Mediterranean.

Fauré-Fremiet's figure of $P$. crassipes has the first apical as an Orthoperidinium and is left-handed. It seems to be more like $P$. Leonis, but is not sufficiently described.

\section{Section Hummia.}

Like Divergens, but without hollow horns.

\section{Peridinium globulus Stein (1883).}

Text-figure 40.

Paulsen, 1908; Nordisches Plankton, pp. 42-43.

Cell globular or lens-shaped, with a very short apical horn hardly apparent. Girdle strongly right-handed, not excavated, with lists supported by spines. Longitudinal furrow narrow, running upwards on to

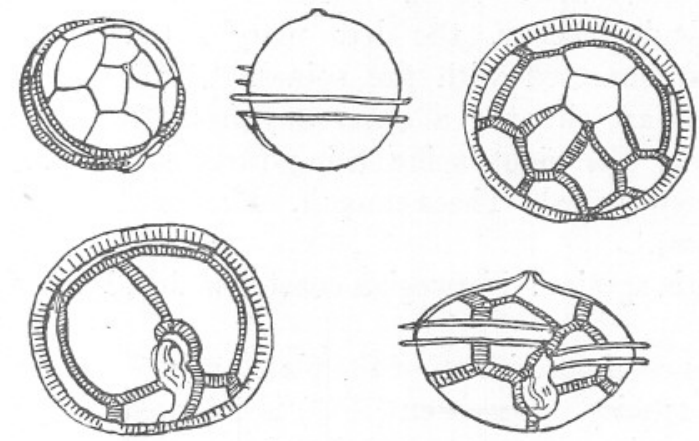

FIg. 40. Peridinium globulus Stein.

ca. 50-78 $\mu$ broad, Rovigno, Adriatic. After Broch, 1910.

the epitheca, with inconspicuous lists. No antapical spines. Theca punctuated. Intercalary striae usually broad. Length $50-78 \mu$ (calculated).

Rare in the North. Spitzbergen, Atlantic, Mediterranean, Adriatic, Pacific and Indian Oceans, Bosphorus (?), English Channel. 
Peridinium cerasus Paulsen (1907).

Plate XXVII, figures 1a-1e.

Paulsen, 1908; Nordisches Plankton, pp. 43-44.

Peridinium globulus Meunier, 1919 (in part).

Cell globular, with a very conspicuous apical horn. Girdle righthanded, not excavated, with narrow lists supported by spines. Longitudinal furrow narrow. Two very fine long antapical spines. Very transparent species. Plasma colourless. Diameter of cell $30-40 \mu$. Neritic.

North Sea, Iceland, Greenland, Mediterranean, Flemish and Brittany coast, English Channel. Very common at Plymouth.

Peridinium quarnerense (Schroeder) from the Adriatic is a closely related species and thought by Broch (1910) to be identical with $P$. cerasus. It differs in having a much less conspicuous apical horn and shorter antapical spines, and in being less globular. Specimens agreeing with this description occur at Plymouth, but are otherwise indistinguishable from $P$. cerasus.

Peridinium roseum Paulsen (1904).

Text-figure 4la.

Paulsen, 1908; Nordisches Plankton, p. 44.

Cell in ventral view, rounded or somewhat rhombic, tapering gradually above to a short apical horn. Girdle right-handed. Longitudinal furrow broadening below, the left margin bearing a small wing which is not connected with the spines. Two spines without conspicuous wings are situated a short way from the end of the longitudinal furrow, the right spine being furthest away. Apical view regularly kidney-shaped. Theca smooth. Plasma pink. Eength $50-58 \mu$ (without spines).

Boreal-neritic species : Norwegian coast, Sweden, Iceland, Skaggerak, Greenland.

In the absence of description of the plate arrangement it is impossible to place this species. Jörgensen (1913) is followed here, who, without figures, places it in this section and describes a variety which he names var. aciculatum. Paulsen (1911) thinks Fauré-Fremiet's P. ovatum (1908) may be this species, but this is figured as an Orthoperidinium. It is, however, quite likely that the first apical is wrongly drawn, as the species is right-handed with solid spines. A small form of the true P. ovatum from Plymouth is much like the present species in outline and was regarded as $P$. roseum (Lebour, 1917) until the plates were elucidated and shown to have the same arrangement as $P$. ovatum. 


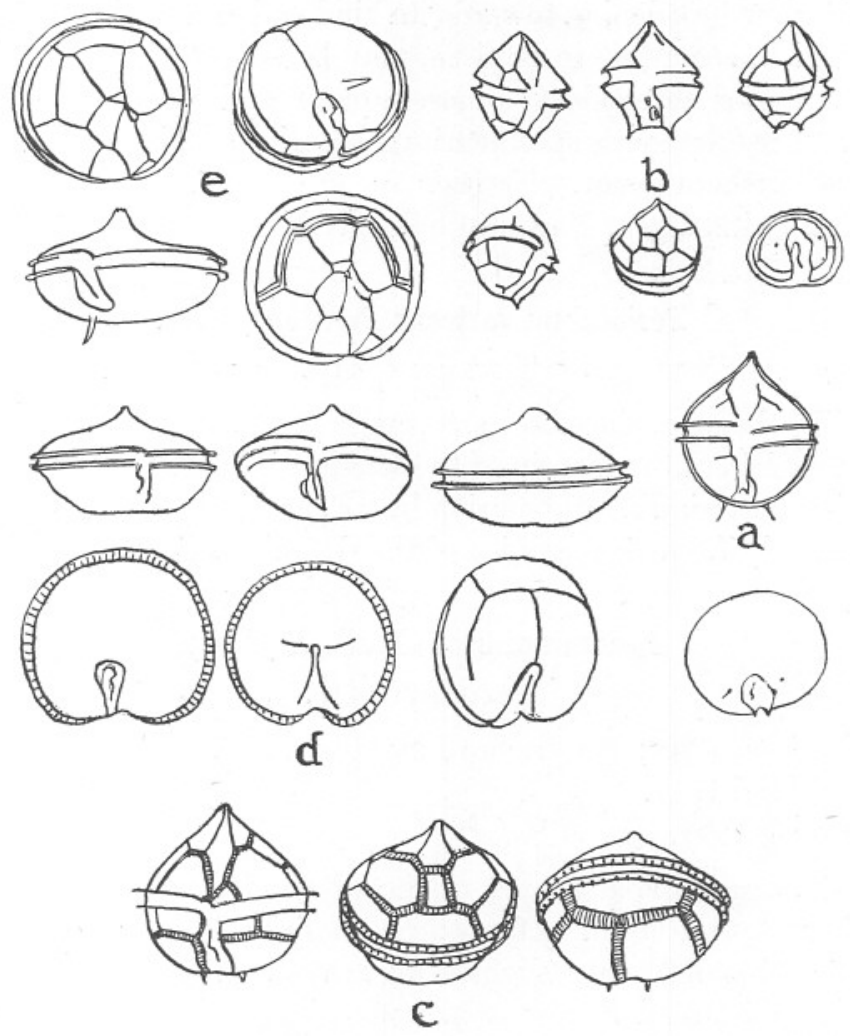

Fig. 41.

a. Peridinium roseum Paulsen.

ca. 50-58 $\mu$ long. After Paulsen, 1908.

b. Peridinium varicans Paulsen.

$36 \mu$ long, E. Greenland Seas. After Paulsen, 1911.

c. Peridinium breve Paulsen.

ca. $56 \mu$ long. After Broch, Spitzbergen.

d. Peridinium decipiens Jörgensen.

75-90 $\mu$ across. After Paulsen, 1907.

e. Peridinium monacanthus Broch.

$66 \mu$ across (Calc.), Spitzbergen. After Broch, 1909.

\section{Peridinium brevipes Paulsen (1908).}

Plate XXVII, figures 2a-2d.

Paulsen, 1908; Nordisches Plankton, p. 108.

Paulsen, 1911, p. 13.

Broch, 1909.

Cell somewhat rhombic in outline, with rounded sides and a conical apex. Girdle right-handed, excavated, with very narrow lists. Longi- 
tudinal furrow broadening towards its hind end and ending in two small spines, which, according to Paulsen, may be absent. Plasma colourless. Second anterior intercalary almost square and very small. Length 18-36 $\mu$. The Plymouth specimens apparently are always smaller than the more Northern forms. Neritic.

Iceland, Spitzbergen, English Channel. Very common at Plymouth.

\section{Peridinium varicans Paulsen (1911).}

Text-figure 41b.

Very like the preceding species, but with the antapical spines diverging and removed from the margin of the longitudinal furrow. A fairly deep impression posteriorly. Tabulation like P. brevipes. Length $36 \mu$.

Known only from the pack ice of the Greenland Seas.

\section{Peridinium breve Paulsen (1907).}

Text-figure 41c.

Paulsen, 1908; Nordisches Plankton, p. 46.

Paulsen, 1911.

Broch, 1909.

Cell of a short ovoid shape, thick-walled, sides somewhat rounded. Very short apical horn. Hypotheca semicircular, slightly flattened. Girdle right-handed, only slightly excavated, with lists supported by spines. Longitudinal furrow broad, with inconspicuous lists ending in two slightly winged spines. Rarely the left spine is separate from the left list. Theca reticulated. Intercalary striae usually broad. Length $44-75 \mu$.

Iceland, Faroes, Spitzbergen, Brittany coast.

This is regarded by Paulsen as a near relative of $P$. Steinii, but if Broch's figures be accurate, and Paulsen himself (1911) refers to these, it certainly belongs to the section Humilia and not to Pyriformia, and this is confirmed by Fauré-Fremiet (1922).

\section{Peridinium decipiens Jörgensen (1899) . Text-figure 41d.}

Paulsen, 1908; Nordisches Plankton, pp. 50-51.

This is again a species in which the description and figures of the plate arrangement are lacking. Jörgensen, however, who first described it, places it in this section. Cell flat, like a cake, above abruptly forming a short apical horn. Girdle right-handed, with lists supported by spines. Margins of the longitudinal furrow with inconspicuous lists ; no antapical 
spines. Apical view roundly kidney-shaped, almost symmetrical. Theca finely reticulated. Length 44-56 . Greatest diameter $75-90 \mu$. Neritic.

West coast of Norway. A longer variety from Iceland and Jan-Mayen.

Broch's P. curvipes (1909) is regarded by Paulsen (1911) as possibly identical with this species, but, as shown below, this seems to be a quite distinct species (see $P$. sub-curvipes).

\section{Peridinium monacanthus Broch (1910).}

Text-figure 4le.

Cell cake-shaped, rather like $P$. decipiens, but with one conspicuous antapical spine on the right outside the list of the longitudinal furrow, which is narrow. Prominent apical horn. Girdle right-handed, with smooth lists not supported by spines. Apicals 2 and 3 very small. Intercalary striae only present in some individuals and only round the junctions of precingulars 3 and 5 with the intercalaries and with precingulars 2 and 6 . Length ca. $66 \mu$ (calculated).

Spitzbergen.

Peridinium sub-curvipes Lebour (1923).

Plate XXVII, figures $3 a-3 e$.

Peridinium curvipes Broch, 1910, pp. 42-43.

This species, assigned by Broch to $P$. curvipes Ostenfeld, is quite distinct from Paulsen's (1908, 1911), to which we must assign the original name of curvipes. It has already been pointed out by Paulsen (1911) and Pavillard (1916) that Broch's was a different species, and Paulsen. suggested that it came very near to $P$. decipiens. A species identical with Broch's has now been found from the English Channel, near the western opening about midway between the English and the French coast, also nearer inshore outside Plymouth Sound, and it is certainly different from $P$. curvipes as recognised by Paulsen and in the present work (see p. 135). Although somewhat like $P$. decipiens in shape, it differs from it in having an antapical spine and a conspicuous left wing; we do not know the plates of $P$. decipiens for comparison with $P$. sub-curvipes.

The present species, which I have named sub-curvipes, is slightly oblique, pellucid, with a faint pinkish tinge and a large pink pusule. It is roundish in outline and flattened from above downwards so as to be somewhat lens- or cake-shaped. There is a distinct apical horn. The girdle is distinctly right-handed, not excavated, supported by conspicuous lists with spines. The longitudinal furrow is slightly oblique, with a list running down the left side which curves round the hind margin. On the right, not connected with the furrow, is a sharply pointed curved antapical spine. The plates show the typical arrangement of the Humilia 
section, but the first apical plate is very oblique, sloping down to near the girdle on the left so as to leave the first precingular very small. The theca is finely granulated. Breadth $44 \mu$. Oceanic.

Spitzbergen, English Channel.

Pavillard's $P$. curvipes (1916) belongs to the same section as this species and only differs in its more rotund form and longer left side of the first apical plate, which touches precingular 2. It is possible that this is a variety of the species described above.

\section{Section Paraperidinium.}

This section consists of those forms having an hexagonal first apical plate touching precingulars $1,7,2$ and 6 , and the second anterior intercalary, as in the section Conica of Orthoperidinium, touching precingulars 3,4 and 5 .

\section{Peridinium pallidum Ostenfeld (1899). Plate XXVIII, figures 1a-1d.}

Paulsen, 1908; Nordisches Plankton, pp. 48-49.

Broch, 1910.

Cell flattened dorso-ventrally, somewhat rhombic in ventral view, longer than broad : conical apex. Girdle slightly right-handed, excavated, with lists supported by spines. Margins of longitudinal furrow ending in conspicuous winged spines, the right in one, the left in two. Theca finely dotted. Plasma yellowish green, usually with numerous small yellowish green chromatophores. Probably holyphytic. Intercalary striae narrow or broad. Length $70-96 \mu$.

Northern Seas, very common. Mediterranean, English Channel. One of the commonest species near Plymouth both near the coast and in the open sea.

\section{Peridinium pellucidum (Bergh) Schütt (1895).}

Plate XXVIII, figures $2 \mathrm{a}-2 \mathrm{~d}$.

Paulsen, 1908; Nordisches Plankton, p. 49.

Cell very slightly flattened dorso-ventrally, broadly oval. Girdle slightly right-handed, excavated, with lists supported by spines. Right margin of longitudinal furrow ending in one, and the left in two, antapical spines; the median spine is concurrent with the left list, and very conspicuous. These spines may be with or without wings; usually wingless in those from Plymouth, Spitzbergen and Greenland, described by Broch as forma spinosa (1910a). Intercalary striae narrow or broad. Theca finely reticulated. Plasma colourless or a very pale pinkish or yellowish, with pink pusule. Length $40-68 \mu$; breadth $36-70 \mu$. Neritic. 
Spitzbergen and Greenland to the Mediterranean-very common. One of the commonest species at Plymouth.

Fauré-Fremiet (1908) describes two varieties, var. crassum and var. acutum, from the coast of Brittany. The latter may be a new species.

\section{Peridinium curvipes Ostenfeld (1906).}

Plate XXIX, figures 1a-1c.

Paulsen, 1908; Nordisches Plankton, p. 45.

Paulsen, 1911, p. 308.

Cell a roundish oval, or slightly flattened from above downwards. Epitheca conical, with a short apical horn. Hypotheca semicircular. Girdle right-handed, with lists supported by spines. Margins of longitudinal furrow each ending in a spine, the left larger and with a very welldeveloped curved wing. Plasma pale yellow. Length $48-52 \mu$; breadth ca. $45 \mu$. Neritic.

Faroes, Iceland and Greenland, English Channel (Plymouth).

Neither Broch's (1910) species nor Pavillard's (1916) belong to this species. Broch's has already been referred to as $P$. sub-curvipes, and Pavillard's is so closely related to this that it may be the same species.

\section{Peridinium islandicum Paulsen (1904).}

Text-figure 42a (see p. 136).

Paulsen, 1908; Nordisches Plankton, pp. 49-50.

Paulsen, 1911.

Broch, 1910.

Cell broad and short, flattened from above, somewhat rhombic. Epitheca with convexo-concave sides. Apical horn short. Girdle righthanded, excavated, with lists supported by spines. Right margin of the longitudinal furrow ending in one, the left in two, antapical spines. Only the spine nearest the left margin is winged. Theca smooth. Intercalary striae narrow or broad. Chromatophores yellow-brown. Length 53-62 $\mu$; breadth up to $83 \mu$ (calculated). Neritic.

Iceland, Greenland, Spitzbergen.

\section{Peridinium diabolus Cleve (1900).}

Plate XXIX, figures $2 a-2 c$.

Pavillard, 1916.

Cell with long apical horn; the hypotheca roundish, with two very long, solid antapical spines, winged, and one accessory spine on the left connected with the longitudinal furrow. Girdle right-handed, not ex- 

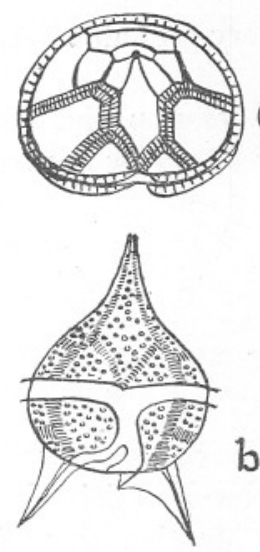

b

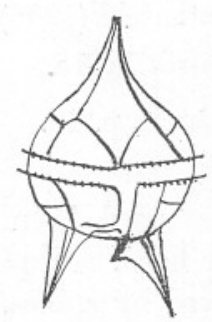

a
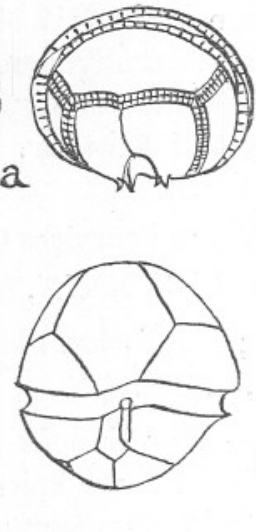

\section{c}

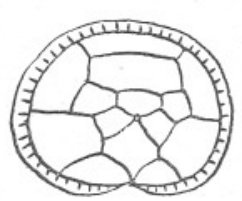

FIG. 42.

a. Peridinium islandicum Paulsen.

$83 \mu$ across (Calc.), Spitzbergen After Broch, 1910.

b. Peridinium macrospinum Mangin. $50 \mu$ long. After Mangin, 1912.

c. Peridinium Balticum (Levander). Lemmermann. $22 \mu$ long, Finnish coast. After Levander, 1894.

cavated, with lists supported by spines. Slightly flattened dorso-ventrally. Length $50-70 \mu$; breadth $42-45 \mu$. Spines $20-22 \mu$.

Atlantic, Mediterranean, Plymouth Sound.

\section{INCERTE SEDIS.}

\section{Peridinium macrospinum Mangin (1912).}

Text-figure $42 \mathrm{~b}$.

This species appears to be an Orthoperidinium from the figures, but it has large winged antapical spines and is therefore, as Pavillard (1916) truly remarks, " a strange figure" there. Pavillard's (1916) Peridinium diabolus Cleve is very like it, except for the first apical, which shows it to belong to the section Paraperidinium in the group Metaperidinium. However, in his first description of $P$. formosum, a closely related species, Pavillard (1909) figures the first apical as Orthoperidinium, and after corrects it in 1916. Thus it is evidently very easy to make such a mistake, and it seems highly probable that $P$. macrospinum will turn out to be a Metaperidinium in the section Paraperidinium, possibly identical with $P$. diabolus, where it would naturally come close to Peridinium pallidum and $P$. pellucidum. Fauré-Fremiet, however (1922), confirms Mangin's description. Mangin's species is described thus :-

Apical portion produced into a distinct terminal neck, transverse furrow equatorial; the antapical* portion rounded, depressed between two long

\footnotetext{
* Mangin writes apical here, which seems to be a mistake.
} 
antapical spines. Accessory left spine with a short apex traversing the margin of the longitudinal furrow. Length (without spines) $50 \mu$, rarely $70 \mu$; breadth $35-40 \mu$, rarely $50 \mu$. Spines $20-22 \mu$ long. Fauré-Fremiet describes it as right-handed, attaining a length of $86 \mu$ and a breadth of $62 \mu$.

Atlantic, Flemish coast, Brittany coast.

Peridinium Balticum (Levander) Lemmermann.

Text-figure $42 \mathrm{c}$.

Paulsen, 1908; Nordisches Plankton, p. 65.

This species is said to have six precingulars, and therefore does not properly belong to Peridinium.

The description shows it to be somewhat similar to Kryptoperidinium foliacum, having very weakly developed plates, an enormous plate in front of the epitheca (resembling the seventh precingular in that species) and a red stigma, besides apparently having a very narrow longitudinal furrow on the left of the ventral area; the cell is flattened dorsoventrally.

Cell circular, dorso-ventrally flattened, very weakly divided into plates. Epitheca broad and larger than the hypotheca. Girdle weakly left-handed. Longitudinal furrow flat and short. No spines present. Epitheca with only six end-plates. Chromatophores small, golden-brown. Below the longitudinal furrow a red stigma. Length 22-30 $\mu$. (Paulsen.)

Finnish coast.

Peridinium exiguum Cleve (Paúlsen, 1908, p. 109) is a peculiar form recorded by Cleve from Plymouth with curiously serrated antapical horns. It is, however, impossible to place this species, which is probably abnormal and has never occurred again.

\section{Genus Minuscula gen. nov.}

This new generic name is offered to include the peridinian described by Paulsen (1904) as Glenodinium bipes, and later (1905) by Pavillard as Peridinium minusculum. It is certainly not a Glenodinium, as its theca is divided into distinct plates, and from their arrangement, as given by Pavillard (1917) and confirmed by myself, it is not a true Peridinium, the plate formula being $4^{\prime} 3 a 6^{\prime \prime} 5^{\prime \prime \prime} 2^{\prime \prime \prime \prime}$; that is to say, with one precingular plate less than in Peridinium. The sixth precingular is very large and occupies the position of 6 and 7 together; the first precingular is also very large and runs in between postcingulars 2 and 3 and antapical 1 . Only one species known :-M. bipes Paulsen. 
Minuscula bipes (Paulsen) (1904).

Plate XXIX, figures $3 \mathrm{a}$ and $3 \mathrm{~b}$.

Glenodinium bipes Paulsen, 1908, p. 25.

Peridinium minusculum Pavillard, 1905.

Peridinium minusculum Pavillard, 1917.

Cell minute, flattened dorso-ventrally. Epitheca triangular, with pointed apex ending in a conspicuous apical horn surrounding a long apical pore. Hypotheca shorter than the epitheca, ending in two long, solid antapical horns, the two antapical plates with conspicuous pores. Girdle slightly right-handed, excavated, with very narrow lists. First apical of the Metaperidinium type, the second anterior intercalary occupying a position between the precingulars 3 and 4. Cell contents colourless. Length with spines ca. 23-35 $\mu$ (Paulsen); less in the English Channel and Mediterranean forms. Neritic.

Greenland, Iceland, Baltic, North Sea, Bosphorus, Flemish coast, Mediterranean, English Channel. Common at Plymouth.

\section{Genus Coolia Meunier (1919).}

This genus was created by Meunier for a most peculiar form found abundantly in the waters round Nieuport, Flanders, especially in the oyster beds. It is unlike any known dinoflagellate. Cell very much lensshaped in ventral view, with an oblique axis. Girdle equatorial, excavated, slightly left-handed. Sulcus not reaching antapex. Apex far back, antapex forward. Theca covered with lines of small dots. Plate arrangement very irregular, composed of 16 plates (according to Meunier, who admits that this may not be accurate), of which 11 belong to the epitheca, 5 to the hypotheca. Epitheca apparently has 8 precingulars and 3 apicals, one of the latter on the left being pierced by a large apical pore. There seems to be no antapical plate. Interpreted as above, the plate formula is $3^{\prime} 8^{\prime \prime} 5^{\prime \prime \prime} 0^{\prime \prime \prime \prime}$. It is possible, however, that the large seventh precingular is an apical.

Coolia monotis Meunier (1919).

Text-figure 43.

With the characters of the genus. Length $32 \mu$ (calculated).

From oyster beds and waters round Nieuport, Flanders.

\section{Genus Pyrophacus Stein (1883).}

Cell flattened from above downwards and of the shape of a bi-convex lens. Epitheca and hypotheca equal. Narrow girdle, indented. Longi- 

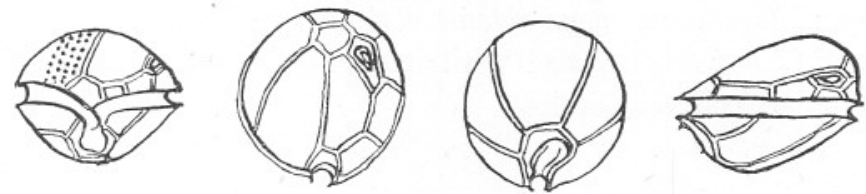

FIG. 43. Coolia monotis Meunier.

$32 \mu$ long (calculated), Nieuport, Flanders. After Meunier.

tudinal furrow short. Plate formula 5-\% apicals, no anterior intercalaries, 9-12 precingulars, 9-12 postcingulars, 3-4 antapicals. Several small plates in the ventral area. Numerous greenish yellow chromatophores. Reproduction by spore formation, two spores being formed within the theca and set free by the girdle opening.

Only one species known, Pyrophacus horologicum Stein.

\section{Pyrophacus horologicum Stein (1883). \\ Plate XXIX, figures $4 \mathrm{a}-4 \mathrm{c}$.}

Paulsen, 1908; Nordisches Plankton, p. 67.

Cell lens-shaped. Theca weakly sculptured, with fine poroids. Intercalary striae narrow or very broad. Length ca. $40 \mu$; breadth ca. 74-90 $\mu$. Oceanic, but comes fairly close inshore occasionally.

Warm seas, Bosphorus, English Channel.

Paulsen regards it as a sub-tropical species seldom brought in by the Gulf Stream in the North; but it also occurs in the Baltic, and is quite common near Plymouth outside the Sound.

All the specimens, even the smallest from Plymouth, had 9 precingulars, 5 apicals, 3 antapicals and 9 postcingulars, and apparently Lindemann's from the Bosphorus (advance reprint, 1923) is the same. These agree with Stein's small form, which he believes to be young; but ours are fully grown, as they have cysts inside. The form with 12 pre- and postcingulars and 7 apicals may thus be another species.

\section{Genus Oxytoxum Stein (1883).}

Cell elongated, club-shaped to spindle-shaped. Girdle deep and broad, near to the front end so that the epitheca is shorter than the hypotheca. Hypotheca often pointed; sometimes the epitheca also. Ventral area short, often much reduced. No apical pore (with the possible exception of $O$. Belgicae Meunier). Plate formula 5 apicals, 5 precingulars, 1 antapical, or $5^{\prime} 5^{\prime \prime} 5^{\prime \prime \prime} 1^{\prime \prime \prime \prime}$. Theca with longitudinal or transverse ridges, and often poroids. Very few in the Northern area. 
Species :-Oxytoxum sphaeroideum Stein, O.gladiolus Stein, O. scolopax Stein, O. Milneri Murray and Whitting, O. diploconus Stein, O. Belgicae Meunier, O. reticulatum (Stein).

\section{Oxytoxum sphaeroideum Stein (1883).}

Text-figure 44a.

Paulsen, 1908; Nordisches Plankton, pp. 68-69.

Hypotheca egg-shaped, behind pointed or blunt. Precingulars sharply bent so that the seams lie in furrows. Epitheca rounded or conical, "or
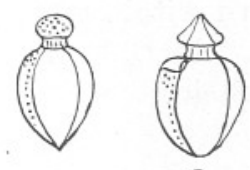

a

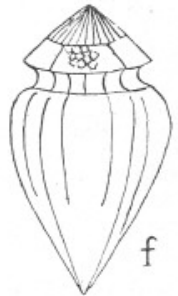

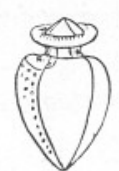

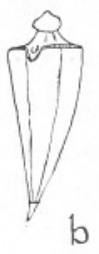

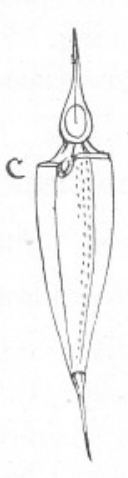

FIG. 44
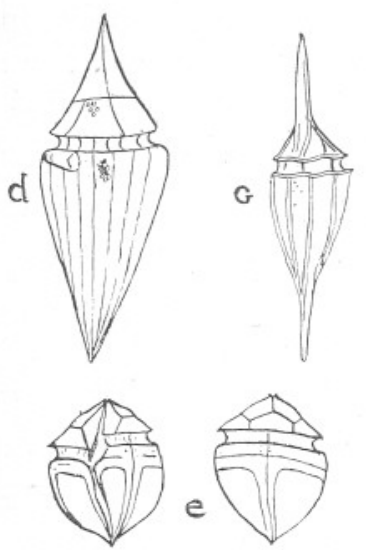

a. Oxytoxum sphaeroideum Stein.

(?) Size. From Paulsen, 1908 ; after Stein.

b. Oxytoxum gladiolus Stein.

(?) Size. From Paulsen, 1908; after Stein.

c. Oxytoxum scolopax Stein.

(?) Size. From Paulsen, 1908 ; after Stein.

d. Oxytoxum diploconus Stein.

(?) Size. From Paulsen, after Stein.

e. Oxytoxum Belgicae Meunier.

(?) Size. Kara Sea. After Meunier, 1910.

f. Oxytoxum reticulatum (Stein), Bütschli.

(?) Size. From Paulsen, after Stein.

g. Oxytoxum Milneri Murray and Whitting.

$\times 290$. After Murray and Whitting.

with a furrow at the base. Theca with distinct poroids (or pores ?) in rows. Size (?).

South Atlantic species. Seldom found in the Gulf Stream region. 


\section{Oxytoxum gladiolus Stein (1883).}

Text-figure 44b.

Paulsen, 1908; Nordisches Plankton, p. 69.

Cell shaped like a tusk. Hypotheca deeply conical, acutely or weakly pointed. Epitheca round or pointed in front. Theca smooth. Small species. Size (?).

South Atlantic species. Rare in the Gulf Stream region.

\section{Oxytoxum scolopax Stein (1883). \\ Text-figure $44 \mathrm{c}$.}

Paulsen, 1908; Nordisches Plankton, pp. 69-70.

Cell spindle-shaped, acutely pointed at each end. Hypotheca very long, ending in a thread-like point, with sometimes a swelling at the base of the point. Epitheca bulbous, with a thin pointed apex. Length up to $112 \mu$.

Tropical Atlantic. Rare in the north in the Gulf Stream region; Mediterranean, Indian Ocean.

Oxytoxum Milneri Murray and Whitting (1899).

Text-figure 44g.

Paulsen, 1908; Nordisches Plankton, p. 70.

Cell spindle-shaped, pointed at both ends, the apical point abrupt. Hypotheca conical, gradually merging into a blunt or acute point. Theca with poroids (or pores ?) and longitudinal ribs. Length up to $131 \mu$.

Sub-tropical Atlantic, Mediterranean. Rare in Northern waters.

Oxytoxum diploconus Stein (1883).

Text-figure $44 \mathrm{~d}$.

Paulsen, 1908; Nordisches Plankton, pp. 70-71.

Cell bi-conical. Hypotheca long and pointed; epitheca short and pointed, with concave sides. Theca with numerous longitudinal ribs and poroids (or pores ?). Length ca. $64 \mu$.

Southern Atlantic species. Rare in the Gulf Stream region in the North.

Oxytoxum Belgicae Meunier (1910).

Text-figure $44 \mathrm{e}$.

Cell an elongated oval, with convex sides. Epi- and hypotheca conical. Epitheca about half as long as the hypotheca. Plates with fine punctures and striations with smooth borders. Length (?).

Kara Sea. (Meunier.) 


\title{
Oxytoxum reticalatum (Stein) Bütschli (1885).
}

\author{
Text-figure $44 \mathrm{f}$.
}

Paulsen, 1908; Nordisches Plankton, p. 72.

Cell a long oval, pointed behind. Epitheca short, conical. Theca longitudinally striated and distinctly reticulated. Length (?).

Southern species. Seldom in the North.

\section{Genus Ceratium Schrank.}

Cell usually flattened dorso-ventrally, drawn out into hollow horns (usually 3). Girdle left-handed, with lists. Theca composed of plates. Plate formula $4^{\prime} 5^{\prime \prime} 5^{\prime \prime \prime} 2^{\prime \prime \prime \prime}$. Ventral area, of several plates, taking up the greater part of the ventral face; the longitudinal furrow in its left side with the flagellar pore. Epitheca with a long apical horn with an apical pore at the top. Hypotheca is typically drawn out into two hollow side horns, the left horn formed by the two antapical plates, the right formed by the postcingulars 4 and 5. Chromatophores numerous yellow plates. Nutrition holophytic. Reproduction by cell division (fission), the theca splitting obliquely and each half forming new plates. Chain formation may take place and, rarely, spore-formation. Supposed sexual reproduction has been described by Zederbauer (1904) and by Entz, jun. (1907), in Ceratium hirundinella, and a few other doubtful cases have also been noted. Division usually takes place at night and in the early morning (see p. 147). Heteromorphic chains sometimes occur; that is to say, the individuals at one end of the chain are quite different from those at the other.

Jörgensen (1910) has divided the Ceratia into four sub-generaPoroceratium, Biceratium, Amphiceratium and Euceratium. The first which has no apical horn, does not occur in our area. The species are referred to his monograph (1911) for synonymy. For details of distribution of the Northern forms, see Jörgensen (1908).

Species :-Sub-genus Biceratium.

Ceratium hirundinella (O. F. Müller), C. candelabrum (Ehrenberg), C. furca (Ehrenberg), C. lineatum (Ehrenberg), C. minutum Jörgensen.

Sub-genus Amphiceratium.

Ceratium extensum (Gourret), C. fusus (Ehrenberg).

Sub-genus Euceratium.

Ceratium tripos (O. F. Müller), var. Baltica Schütt, forma subsalsa Ostenfeld, forma hiemale Paulsen, var. Atlantica Ostenfeld, forma neglecta (Ostenfeld), C. compressum Gran, C. azoricum Cleve, C. bucephalum (Cleve), var. heterocampta Jörgensen, C. gibberum Gourret, forma sinistra Gourret, C. platycorne v. Daday, C. lamellicorne Kofoid, 
C. macroceros (Ehrenberg), C. horridum Gran, C. longipes (Bailey), C. arcticum (Ehrenberg) Cleve, C. reticulatum (Pouchet) Cleve.

\section{Sub-genus Biceratium (Vanhöffen) Gran.}

Cell with an apical horn (in all the Northern forms), two hind horns, exceptionally three $(C$. hirundinella $)$, normally shut at the tips, backwardly directed behind, parallel or diverging, the right smaller, seldom curved, rarely shorter than half the left. Epitheca (including horn) mostly much longer than the hypotheca, only in short and broad short horned forms (C. candelabrum) as long or a little shorter.

Ceratium hirundinella (O. F. Müller) (1786).

Plate XXX, figure 1, Text-figure 45a (see p. 144).

Paulsen, 1908; Nordisches Plankton, pp. 87-88.

Jörgensen, 1911, p. 14.

Cell strongly flattened dorso-ventrally. Apical horn long and thin Two or three hind horns, usually three, the extra horn on the left. Theca spiny and coarsely reticulate. Very variable species. Breadth* $42-80 \mu$. Resting spore triangular, with a spine at each angle (Text-figure 45a).

Fresh water; also in brackish water in the Baltic. Common throughout Europe into Asia.

Entz, jun. (1924), has observed chain formation in this species, and also describes interesting cases of the sticking together of two individuals (" coupling").

Ceratium candelabrum (Ehrenberg) (1859).

Plate XXX, figure 2, Text-figures $45 \mathrm{~b}$ and $45 \mathrm{c}$.

Paulsen, 1908; Nordisches Plankton, p. 88.

Jörgensen, 1911, p. 16.

Cell depressed, thick, broader than high. Epitheca merging rather abruptly into a long apical horn which is sometimes curved, sometimes straight. Hypotheca much depressed on the right, somewhat triangular. Hind horns slightly diverging or nearly parallel. Girdle lists strongly developed, with spines. Ridges and pores on the theca. Sometimes winglike lists. Very variable. Breadth $55-70 \mu$.

* The breadth here and throughout the genus is the breadth across the girdle, ventral view ; the total length, when given is from the top of the anterior spine to the hind end of the posterior horns, except when otherwise stated. 
Widely distributed in all warm seas. Also rarely from Denmark, Skaggerak, Atlantic.

The variety dilatata (Gourret) has the body strongly compressed, much broader than high. All the horns usually long and bent (in the type straight), the hind horns more or less diverging. In warm seas, more widely distributed than the type. This variety forms chains, the individual behind fitting into the one in front by the apical horn, which
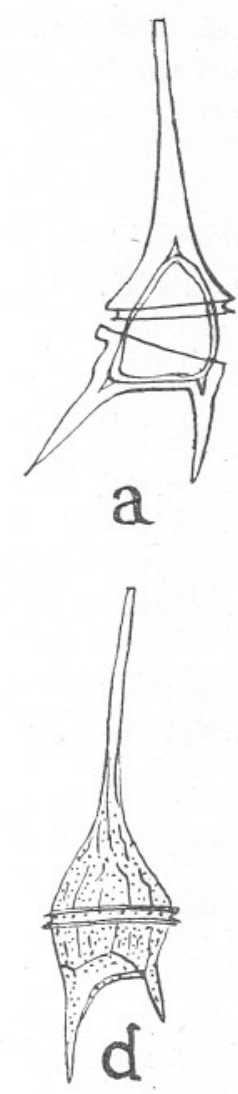
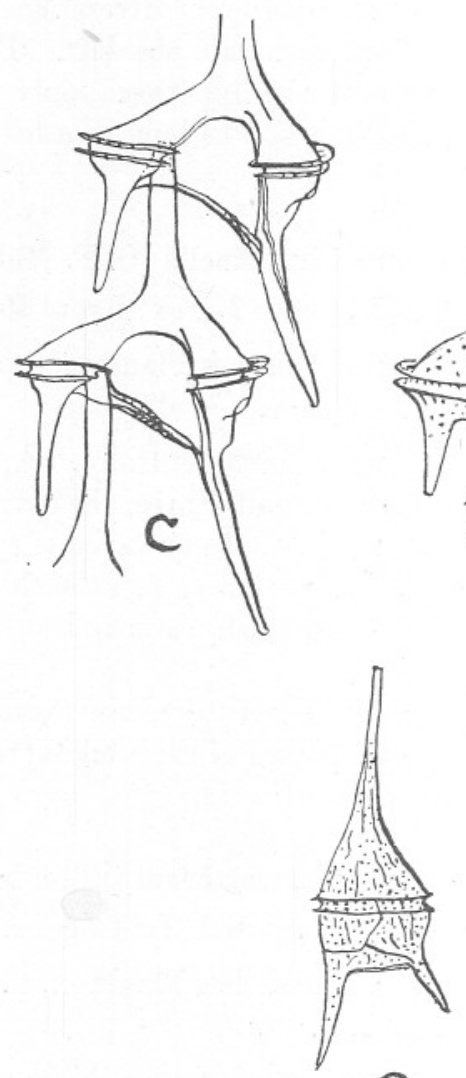

e

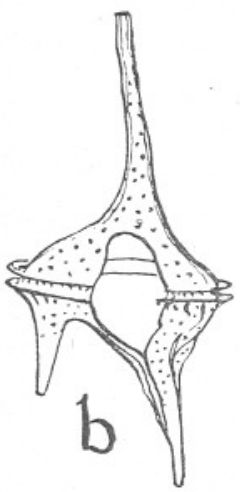

FIG. 45.

a. Ceratium hirundinella (O. F. Müller).

With resting spore. After West, 1916.

$b, c$. Ceratium candelabrum (Ehrenberg).

b. Type. Berguelostrom. After Jörgensen.

c. var. dilatata, in chain.

Straits of Gibraltar. After Jörgensen.

d, e. Ceratium lineatum (Ehrenberg).

d. $\times 280$. South of New York. After Jörgensen, 1913.

e. Bergen, Norway. After Jörgensen, 1913. 
fits into a special groove (Text-figure 45c). These chains are formed by cell division, and the individuals hold together in this way with a loose union.

\section{Ceratium furca (Ehrenberg). Plate XXX, figure 3.}

Paulsen, 1908; Nordisches Plankton, pp. 89-90.

Jörgensen, 1911, p. 17.

Cell elongated. Epitheca evenly narrowing and drawn out into a longer or shorter apical horn. Hind horns parallel or somewhat diverging, the left longer and stronger than the right, which is about half the length of the left. Both horns more or less sharp, commonly toothed, the left most conspicuously. The type is regarded by Jörgensen as the sub-species Berghii (Lemm.), which is the Northern form, the sub-species eugrammum (Ehrenberg) occurring only in warm seas. Breadth (in type) $30-50 \mu$.

Temperate cold-water form. Northern temperate Atlantic to English Channel, Baltic, Northern waters. Rare in Polar stream.

\section{Ceratium lineatum (Ehrenberg) (1854).}

Text-figures $45 \mathrm{~d}$ and $45 \mathrm{e}$.

Jörgensen, 1911, p. 22.

Ceratium tripos f. lineata Paulsen, 1908; Nordisches Plankton, pp. 88-89.

Small species, much longer than broad, the girdle a little behind the middle. Epitheca triangular, with nearly straight sides, which usually make an angle of about $55^{\circ}$ with one another. Apical horn produced, somewhat narrower at the apex, long. Hypotheca trapezoidal. Hind horns straight, more or less diverging to almost parallel, the right $\frac{1}{3}-\frac{2}{3}$ the length of the left. Theca with conspicuous lines and pores. Breadth $25-47 \mu$.

Northern form of the temperate and cold Atlantic. Common on the European coast, especially in the North Sea and Norwegian Seas; also on the American side north of the Gulf Stream.

The species recorded from Plymouth in 1917 (Lebour) is C. minutum.

Ceratium minutum Jörgensen (1920).

Plate XXX, figure 4.

Ceratium eugrammum Kofoid, $1907 \mathrm{~b}$.

Very small species. Epitheca in ventral view, somewhat triangular and abruptly narrowing to a slender, usually straight apical horn. Hypotheca tapering, with almost straight or slightly convex sides. Hind horns 
nearly parallel, usually very slightly diverging, the longer one (the left) shorter than the hypotheca, the right about half the length of the left : both acute and slightly denticulated. Breadth $23-35 \mu$, usually $25-28 \mu$. Theca with ridges and lines and distinct pores.

Pacific from Alaska to San Diego, English Channel (Plymouth), coast of Brittany to Straits of Gibraltar, Mediterranean.

Kofoid's figure from the Pacific has much slenderer horns than the Plymouth specimens. This species occurs sometimes in numbers at Plymouth and outside.

\section{Sub-genus Amphiceratium (Vanhöffen).}

Cell long and narrow; not, or only slightly, flattened dorso-ventrally. Right hind horn very small, often rudimentary or absent, the left very long and strongly developed, so that the hypotheca with the horn is about as long as the epitheca with the apical horn, sometimes still longer. Horns normally closed at the tips.

\section{Ceratium extensum (Gourret).}

Text-figure 46a.

Paulsen, 1908; Nordisches Plankton, p. 91.

Jörgensen, 1911, p. 28.

Very long species. Epitheca long and narrow, gradually merging into a long straight, narrow apical horn. Right horn absent. Breadth 23-30 $\mu$. Total length more than a millimetre, as long as $1.75 \mathrm{~mm}$. or more.

Warm waters. Rarely in the Northern Atlantic.

\section{Ceratium fusus (Ehrenberg) (1859). Plate XXXI, figure 1.}

Paulsen, 1908; Nordisches Plankton, pp. 90-91. Jörgensen, 1911, p. 29.

Epitheca long and regularly narrowing into a long apical horn almost evenly broad or narrowing towards the apex, usually regularly and weakly bent towards the dorsal side, sometimes straight. Hypotheca narrowed, longer than broad. Left hind horn long, usually bent dorsally distinctly but regularly, seldom quite straight. Right horn rudimentary or absent, mostly forming a short point, rarely appearing as a short narrow pointed horn. Breadth $15-30 \mu$. Total length $300-600 \mu$.

Northern seas, very common. Also a narrow smaller form in warmer seas.

This species is one of the commonest organisms causing phosphorescence in the sea. 
a
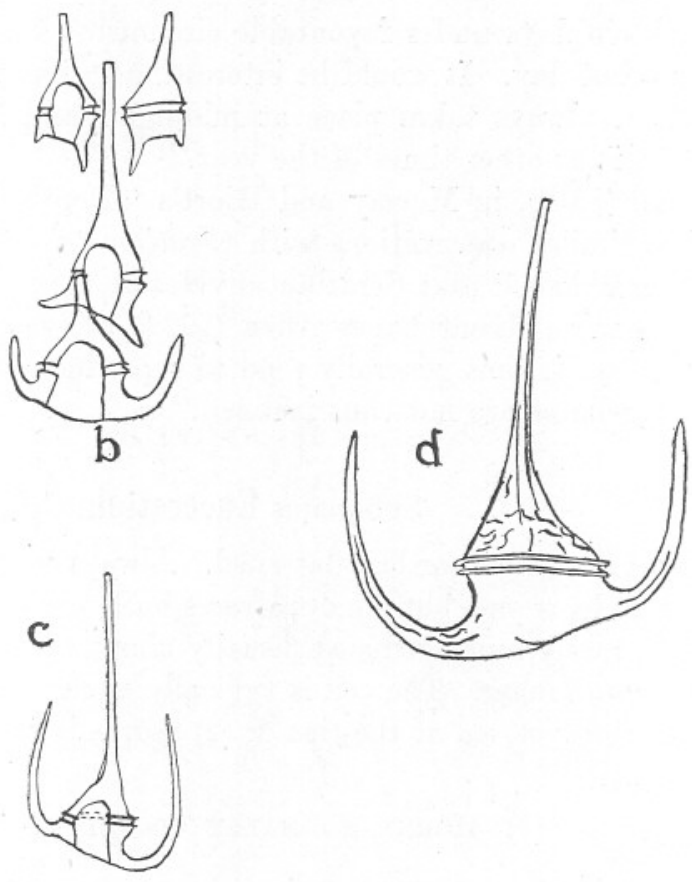

FIG. 46.

a. Ceratium extensum (Gourret). $\times 100$, Gibraltar. After Jörgensen, 1913.

b. Ceratium tripos (O. F. Müller), chain formation. Baltic. After Lohmann, 1908.

c. Ceratium tripos, var. Baltica f. hiemale Paulsen. $\times$ 66.6, Kattegat. After Paulsen, 1908 .

d. Ceratium tripos, var. Baltica f. subsalsa.

$\times 186.6$, Bergen. After Jörgensen, 1913.

Ceratium fusus is widely distributed in the Channel. Gough (1905) made some exceedingly interesting observations on the division and rate of growth. He took a series of samples 10 miles S.W. $\frac{1}{4}$ S. of the Eddystone, July 1st and 2nd, 1903, at intervals of two to three hours.

"Until 11 p.m. all the specimens observed had both horns fully developed and nearly equally long. At 12.55 a.m. one individual in every 160 had very recently divided; the others were still unchanged. At 3.30 a.m. $70 \%$ of the specimens present had one long and one short horn; in other words, about half the individuals present at 1 a.m $(53.8 \%)$ must have recently divided. After 7 a.m. no further new divisions were observed, and the new horns were longer than those seen in the previous sample. At 9.30 a.m. all specimens seen had both horns of equal growth. The rate of division for each cell would thus be once 
every two days under favourable circumstances. The 1st of July had been a hot day. It would be interesting to know if the cell division of C. fusus always takes place at midnight, and how rapid the rate of growth is at other times of the year."

Gran (1912), in Murray and Hjort's "Depth of the Ocean," p. 374, makes similar observations with Ceratium tripos, and it appears to be fully established that Ceratium divides at night.

In a more recent paper Allen (1922) brings evidence to show that "whereas diatoms generally tend to reproductive activity at night . . . dinoflagellates are not thus inclined."

\section{Sub-genus Euceratium Gran.}

Cell broad, more or less flattened. Always two hind horns present, of which at least one, but almost always both, are bent forward. The right horn is rarely much reduced, usually about the same length as the left, sometimes longer. The cell is typically anchor-shaped. Horns may be (1) normally closed at the tips or (2) normally open at the tips.

\section{(1) Horns noRmally closed at the Tips.}

Ceratium tripos O. F. Müller (1777).

Plates XXXII, a, b and c ; XXXIII. Text-figure 46, b, c and d.

Paulsen, 1998; Nordisches Plankton, pp. 77-80.

Jörgensen, 1911, p. 35.

Fairly large species. Body about as broad as it is long. Epitheca rather flattened, commonly almost twice as broad as it is long, the left side contour a little convex, the right strongly so. Hypotheca as long as the epitheca or a little longer, the left side contour usually more or less strongly concave. All the horns strong, the apical horn usually broader below than the others, and the right hind horn usually conspicuously more weakly developed than the left. Hind horns at the apex diverging somewhat, but the right least. Sometimes the right horn is parallel with the apical horn or, rarely, somewhat converging towards it. The left horn can also be parallel with the apical horn or converge slightly towards it. Plate structure very strong. Usually the theca has strong longitudinal lines, often anastomosing. Pores conspicuous. Lists may also be present. Very variable species. The hind horns closed at the tips, which are pointed. Jörgensen divides $C$. tripos into two common varieties :-

\section{Variety 1. Baltica Schütt (1892).}

Hind horns conspicuously unlike, diverging, the right smaller, mostly 
about as long as the body, at the base more or less abruptly bent, especially the right, in the distal part almost in a straight line and nearly parallel with the apical horn. The left hind horn longer and stronger, mostly regularly bent, diverging from the apical horn. Hind margin of the cell a little swollen or almost a straight line. Breadth $60-80 \mu$ or rarely more.

Very common in the Northern Atlantic, Baltic, Kattegat and Skaggerak, North Sea, Norwegian Seas, English Channel. Also North American coast in cold water, east and west of the Florida stream.

Two forms are differentiated of this variety :-

(a) Forma subsalsa Ostenfeld (1903)

(var. subsalsa Paulsen, 1908, p. 79).

Hind horns conspicuously unlike, parallel or a little converging; the right smaller, longer than the body, bent from the base, in the distal part a straight line, and often converging somewhat towards the apex or parallel with it. Left hind horn of the same shape, with the apex parallel with the apical horn, slightly converging. Hind margin of the cell at most a straight line, not conspicuously swollen. Breadth $72-74 \mu$.

Distribution - as in var. Baltica.

(b) Forma hiemale Paulsen (1907) (1908, p. 80).

$$
\text { , " Jörgensen, 1911, Text-figure 66c. }
$$

Like the preceding form, but with longer hind horns, which are paralle with each other in front or a little converging, but otherwise can be differently directed. The apices of the hind horns are often somewhat bent out.

Distribution like the preceding form. On the Norwegian coast in winter and early spring.

Variety 2. Atlantica Ostenfeld (1903).

Plate XXXIII.

Paulsen, 1908, p. 78.

Jörgensen, 1911.

Hind horns usually of the same size, similarly bent as in the preceding form, more or less diverging at the apices. The right hind horn is distinctly longer than the body, at the tip parallel with the apical horn or usually a little diverging, the left also parallel or diverging. Sometimes, but rarely, is the right hind horn longer than the left, but then usually distinctly narrower. Hind contour convex and swollen. Many different forms, partly with long apical horns and short hind horns, partly with 
short apical and relatively long hind horns. Also the width between the tips of the hind horns varies much, and these forms show a great variation in the presence of wing-like lists.

The chief form is neglecta (Ostenfeld) Paulsen.

Hind horns slightly dissimilar, the right somewhat smaller. Hind contour of the cell almost imperceptibly merging into the horns, convex. Apical horn very broad at the base and with several large toothed winglike lists. This is possibly to be regarded as an old large form. Breadth $75-93 \mu$.

Var. Atlantica and f. neglecta very commonly distributed in the North Atlantic, Norwegian west coast, English Channel. Common at Plymouth.

Chain formation is common in Ceratium tripos, and it is in this species that the heteromorphic chains are most conspicuous. A Ceratium tripos of the ordinary form divides up into a chain, gradually forming individuals less and less like itself until the end cell is more like a stunted Ceratium furca. A chain of such individuals shows a typical C. tripos at the base, gradually merging through forms like $C$. lineatum and finally to a form like a stunted $C$. furca. These latter are apparently distinguishable from such true species as C. lineatum, C. furca and their allies (see Jörgensen, 1911, p. 38), as they bear the marks of division, are thicker in the body, and the hind horns, especially the right, are strongly directed ventrally. Also the structure of the plates is different.

These forms are known especially from waters of a low salinity such as the Baltic (Lohmann, 1908). They are regarded by Jörgensen as probably degenerate forms.

\section{Ceratium compressum Gran (1902).}

Text-figure $47 \mathrm{a}$.

Paulsen, 1908; Nordisches Plankton, p. 81.

Jörgensen, 1911, p. 39.

Cell strongly flatteried; all the horns in about the same plane. Epitheca high, with weakly convex to almost straight sides, which make an unusually acute angle with one another (about $60^{\circ}$ or less), gradually merging into a very strongly developed broad apical horn. Hind horns broad, equally bent, narrowing towards the tips, where they are nearly parallel, but the left horn diverges a little from the apical horn, while the right usually converges slightly. Right hind horn smaller than the left. Theca with numerous strong ridges irregularly anastomosing; strong spine lists along the apical horn, and smaller lists on the hind horn and the hind margin. Breadth $56 \mu$.

Rare; temperate North Atlantic, Norwegian Seas. 

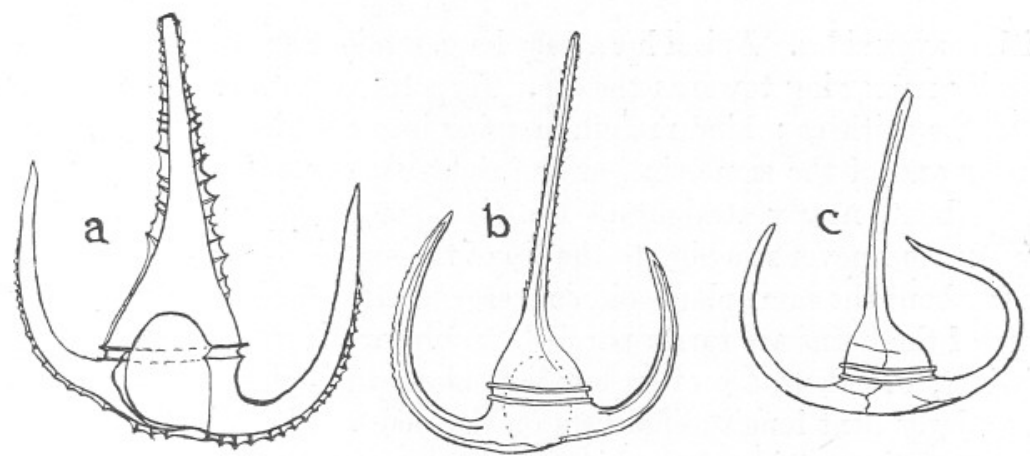

FIG. 47 .

a. Ceratium compressum Gran.

$\times 280$, Norwegian Sea. After Jörgensen.

b. Ceratium bucephalum (Cleve).

(?) Size. West coast of Norway. After Jörgensen, 1899.

c. Ceratium bucephalum var. heterocampta Jörgensen.

(?) Size. West coast of Norway. After Jörgensen, 1899.

Ceratium azoricum Cleve (1900).

Text-figure 48.

Paulsen, 1908; Nordisches Plankton, p. 76.

Jörgensen, 1911, p. 47.

Cell short, with short horns. Hind margin rounded and merging gradually into the hind horns which are bent ventrally, the right smaller
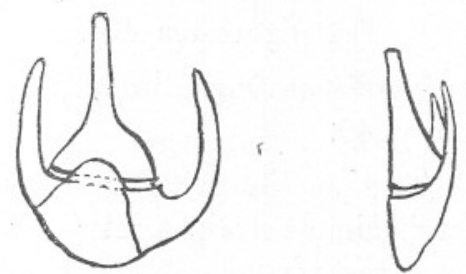

Frg. 48. Ceratium Azoricum Cleve.

$\times 250$. Ventral side view. After Cleve.

than the left. Total length (from tip of apical horn to base of hypotheca) 88-130 $\mu$.

Sub-tropical seas, occasionally brought into the north.

Ceratium bucephalum (Cleve) (1897).

Text-figure $47, \mathrm{~b}$ and $\mathrm{c}$.

Paulsen, 1908; Nordisches Plankton, pp. 76-77.

Jörgensen, 1911, p. 47.

Rather small species, body longer than broad. Epitheca rather long, 
with convex sides. Apical horn very long, straight or curved at the base, usually narrowing towards the tip. Hypotheca not, or a little, shorter than the epitheca; hind margin merging into the hind horns, which are strong and of the same size, or the right usually a little smaller, both much bent, nearly straight at the tips, sometimes longer, sometimes shorter, but never reaching to the tip of the apical horn. All three horns lie in about the same plane and converge usually distinctly at the apices. Two of the horns are rarely parallel. Sculpture of the theca usually not distinct, but there are often low lists along the apical horn, and short irregularly bent longitudinal lists on the body. The sides of the apical horn and the outside of the hind horns are often toothed, but never on the hind margin. Breadth 54-64 $\mu$. Greatest length (from tip of apical horn to end of hypotheca) $240 \mu$.

Northern temperate species. North Sea and Norwegian Seas, Skaggerak and Cattegat, English Channel. Also in the northern and eastern part of the Florida Stream and coast of America.

Var. heterocampta (Text-figure 47c) Jörgensen, 1899 (Ceratium heterocamptum Paulsen, 1908, pp. 76-77). Like the type, but with the right hind horn so strongly bent inwards that the length is almost perpendicular to the apical horn. Length ca. $176 \mu$.

Warm seas. Common on the west coast of Norway.

\section{Ceratium gibberum Gourret (1883).}

Text-figure $49 \mathrm{a}-49 \mathrm{c}$.

Paulsen, 1908; Nordisches Plankton, p. 75.

Jörgensen, 1911, p. 49.

Large but short-horned species with thick body, little flattened. Epitheca low, left margin almost straight. Apical horn more or less bent below to the left, then almost straight, rather long, narrower towards the tip, provided below with short wing-like lists, which are often strengthened by transverse ribs. Hypotheca much longer than the epitheca, with a very oblique left margin. Hind margin strongly convex and more or less swollen out, the swelling not merging into the horns. Left hind horn strong, regularly bent at the tip, almost parallel with the apical horn. Right hind horn weaker and usually shorter, of very variable form ; always strongly bent forwards and ventrally, from the base outwards, then bent dorsally, either almost straight and more or less converging towards the apical horn, or strongly and obliquely bent towards it or even sometimes behind it. Structure of theca very variable; large pores and irregularly anastomosing lists, which are either high and form few large meshes, or more rarely are numerous and form small reticulations. 

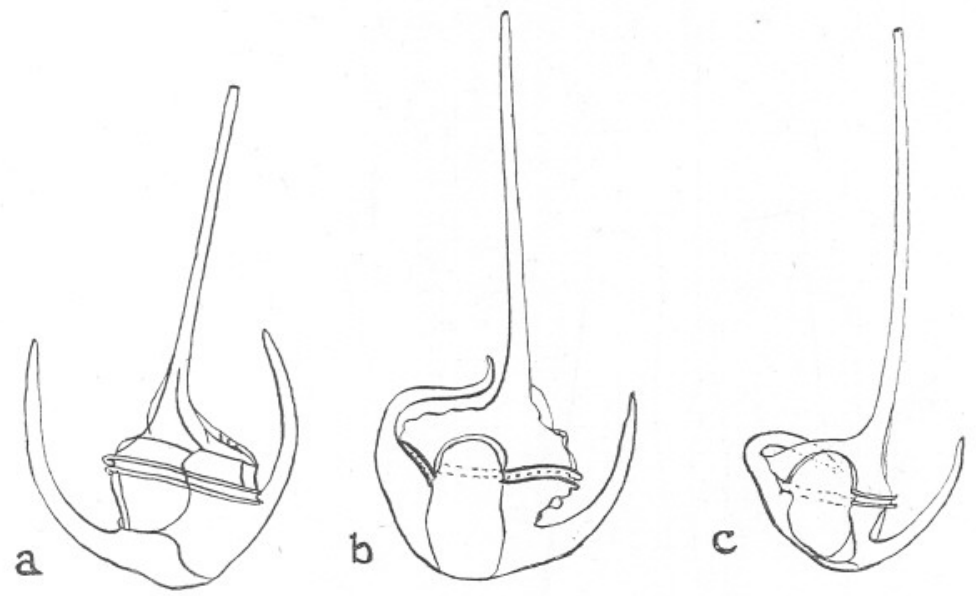

FIG. 49. Ceratium gibberum Gourret.

a. From Florida stream, East American coast.

b. var. sinistra, East coast of Spain.

c. (?) Size, var. sinistra, Gibraltar Straits.

The form sinistra of Gourret has the right hind horn first directed ventrally, then bent towards the dorsal side and almost at a right angle to the apical horn, or even behind it, again bent back at the thin tip. Breadth $71-105 \mu$.

Warm-water species, widely distributed. Seldom in the North and English Channel.

Ceratium platycorne von Daday (1888).

Text-figures 50a and 50b (see p. 154).

Paulsen, 1908; Nordisches Plankton, pp. 74-75.

Jörgensen, 1911, p. 58.

Body much longer than broad. Epitheca long and narrow, with not very convex sides. Hypotheca shorter than the epitheca, with straight or weakly concave sides. Hind margin somewhat convex, on both sides distinct from the horns. Apical horn rather long, straight or weakly bent, narrow towards the tip. Hind horns very strongly developed, alike at the base and at the body level bent forwards into broad flat plates which bend inwards on the inner side. Right hind horn from its origin directed a little forward. The similar bases of the hind horns are very short, much shorter than the very broad plate-like part. Sculpture usually inconspicuous, but there are some longitudinal ridges, and on the hind border spiny lists which run up the outside of the hind horns as far as about the middle, like fine seams. Breadth $48-64 \mu$.

Rare warm-water species, sometimes in the North brought by the Gulf 

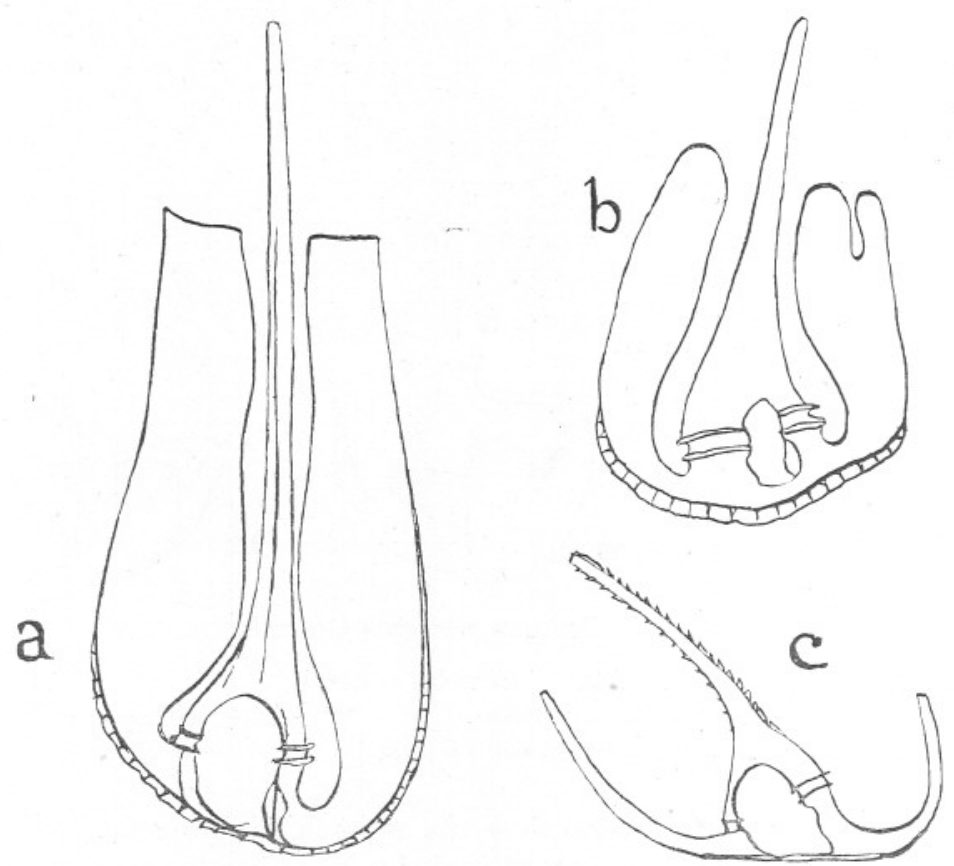

FIG. 50.

Ceratium platycorne v. Daday.

a. $\times 280$, Atlantic Ocean. After Jörgensen, 1913.

b. (?) Size. From Paulsen, 1908 ; after Daday.

c. Ceratium longipes (Bailey) Gran.

$\times 150$. After Ostenfeld, 1903.

Stream. In Paulsen's figure (1908) from v. Daday the left hind horn is bifurcate.

Ceratium lamellicorne Kofoid (1908).

$$
\text { Plate XXXIV, figure } 1 .
$$

Jörgensen, 1911, p. 58.

Very similar to $C$. platycorne. Epitheca not so narrow; hind horns narrower, similar at the base for a fairly long way, then broadening, but usually only to $1 \frac{1}{2}-2$ as broad as at the base. These broad parts of the hind horns have their inner margins rather far away from the body, usually only a little longer to twice as long as the narrow base. Apical horn at the base not specially broad. The left hind horn is at its origin only slightly directed behind. Sometimes the left hind horn is bifurcate and then correspondingly broadened. Structure sometimes very strong; distinct pores and rather numerous strongly developed bent ridges. Winglike lists frequent. Horns usually short. Breadth $42-51 \mu$. 
South and North Atlantic, Azores, South-west Spain, Mediterranean, Indian Ocean, South Africa, California. A rare visitor in the North. Found occasionally at Plymouth.

\title{
(2) Horns normally open at the Tips.
}

Ceratium macroceros (Ehrenberg) (1840) Cleve.

\author{
Plate XXXV.
}

Paulsen, 1908; Nordisches Plankton, pp. 81-82.

Jörgensen, 1911, p. 63.

Medium-sized, long-horned species, the side horns open at the tips. Body very thick and concave, longer than broad. Epitheca not very deep, broad and depressed, with concave sides. Hypotheca somewhat longer than epitheca, with strongly oblique left side. Hind margin almost straight, on both sides making an oblique angle with the hind horns. Apical horn long, broad at the base, straight or slightly bent. Hind horns first diverging behind, then rather suddenly bent forward, diverging more or less from one another and from the apical horn; later they make a broad bow and are at the tips nearly or quite parallel with the apical horn. The right hind horn has its origin somewhat behind the girdle and is strongly ventrally directed. Theca sculpture strong, rather numerous irregularly bent longitudinal ridges and large pores. At the bends the hind horns are usually heavily toothed. Breadth $45-57 \mu$.

A temperate Northern species, rather widely distributed in the North Atlantic, especially in the North Sea and neighbouring waters (Skaggerak, Kattegat), Norwegian Seas, English Channel. Also in the colder waters on the American side.

Sub-species Gallicum Kofoid is a smaller and slenderer species occurring in warmer seas.

\section{Ceratium horridum Gran (1902). Plate XXXIV, figure 2.}

Ceratium intermedium Paulsen, 1908; Nordisches Plankton, p. 83.

Ceratium intermedium Jörgensen, 1902, 1911, p. 83.

Ceratium horridum Jörgensen, 1920.

Rather small or medium-sized species, short-horned and robust. Epitheca deeply triangular, with weakly convex sides. Hypotheca rather longer than the epitheca. Hind margin distinctly indented on the right, not distinctly on the left, almost straight or slightly convex, on the right making a more or less distinct angle with the hind horn. Apical horn in the lower third strongly developed and often slightly bent, usually straight towards the tip. Left hind horn directed obliquely to the left behind, then bent forward and either converging or diverging from the 
apical horn. The right hind horn from its origin slightly directed behind, then bent forward and running nearly parallel to or slightly diverging from the apical horn. Theca sculpture not very apparent, but sometimes there are irregular ridges usually heavily toothed along the bends of the hind horns and the apical horn. Very variable species. Jörgensen (1911) includes several forms hitherto regarded as separate species under the name C. horridum, which Gran divides into a Northern and a Southern form. The present description refers to the Northern form, which amongst others includes Paulsen's form frigida and C. batavum. Breadth $42-47 \mu$.

A Northern temperate form from the English Channel to the north of Norway, North Sea, Skaggerak, Baltic, Norwegian Seas.

Paulsen (1907) describes a long-horned form frigida in spring from the North Sea and the Kattegat.

\section{Ceratium longipes (Bailey) (1854) Gran.}

Plate XXXI, figure 2, Text-figure 50c.

Paulsen, 1908; Nordisches Plankton, pp. 85-86.

Jörgensen, 1911, p. 84.

Medium-sized or rather small species, with strongly bent apical horn. Epitheca almost triangular, with strongly convex left and less convex right side. Hypotheca longer than epitheca, usually distinctly broadened behind, which gives the whole body a triangular appearance. Hind margin usually not, or very little, sunk in, the left more distinctly than the right coming off at an angle from the hind horn, usually a little convex. All horns strong, towards the tips very narrow, open. Apical horn more or less strongly bent. Left hind horn first obliquely directed behind, then similarly bent forward. The right hind horn usually a little longer, at its origin directed almost straight, then quickly bent forward. The tips of the apical and right horns usually about parallel or converging slightly ; the tips of apical and left horn diverging. The hind horns are usually shorter than the apical. Theca sculpture usually strong, numerous coarse ridges and pores present. Along the apical horn and the convex outer parts of the hind horns the lists are more or less toothed. Very variable species. Breadth $51-57 \mu$.

A North Atlantic form which inhabits the rather cold water mixing between the Arctic Stream and the temperate water of the Atlantic. English Channel northwards. Common at Port Erin, Isle of Man.

Jörgensen recognises two varieties:-var. Baltica Ostenfeld (1903), a very large form with thick apical horn with toothed lists, and var. ventricosa Ostenfeld (1903), which is more like C. horridum in some ways, but has the much bent apical horn. 
Ceratium arcticum (Ehrenberg) Cleve.

Plate XXXI, figure 3.

Paulsen, 1908; Nordisches Plankton, pp. 86-87.

Jörgensen, 1911, p. 85.

Medium-sized species with horns very far apart, otherwise similar to C. longipes. Body as broad as long, or even a little broader. Epitheca with very convex sides. Hypotheca much longer than the epitheca, left side almost straight, not obliquely placed, but parallel to the girdle and about parallel to the lower part of the apical horn. Hind margin somewhat convex, not sunk in. The apical horn strongly bent as in C. longipes. Left hind horn at the base obliquely directed behind (but less obliquely than in C. longipes), uniformly bow-shaped, but rather slightly bent. Right hind horn springing almost straight, but bent forward slightly. Apical horn strongly bent. The three horns strongly diverging, the apical and right horn least. Theca sculpture generally very strong, numerous irregularly bent ridges present. Along the apical horn and the convex sides of the hind horns are usually relatively broad, spiny or strongly toothed wing-like lists. On the hind margin are three usually distinct, ridged lists, of which the left is the largest. Breadth $48-60 \mu$.

Cold-water form. Common in the Newfoundland Bank, northern Norwegian Seas and North Atlantic; rare on the west coast of Norway and North Sea. Occasionally in the English Channel and Irish Seas. Also rarely as far south as Gibraltar and the Azores, Japan.

\section{Ceratium reticulatum (Pouchet) Cleve.}

Text-figure 51 (see p. 158).

Paulsen, 1908; Nordisches Plankton, pp. 82-83.

Jörgensen, 1911, p. 86.

Large and very long-horned form. Body concave, about as long as broad, or a little longer. Epitheca not very deep, rather low (short), with slightly convex sides. Left side of the hypotheca nearly straight. All three horns very long, slender, thin-walled and bent in different directions, none lying in the body plane. Hind margin convex, on both sides of the hind horns indented, but not forming a distinct angle with them, not, or only slightly, sunk in. Apical horn nearly straight or rather strongly bent, directed ventrally for the first third, then bent back. Left hind horn at the base directed slightly behind, then strongly bent forwards, then nearly straight and converging towards the apical horn and also ventrally directed. Right hind horns issuing from a little behind the girdle, only directed at a right angle towards the apical horn, drawn out to a slender end, usually directed dorsally and forward. Theca 


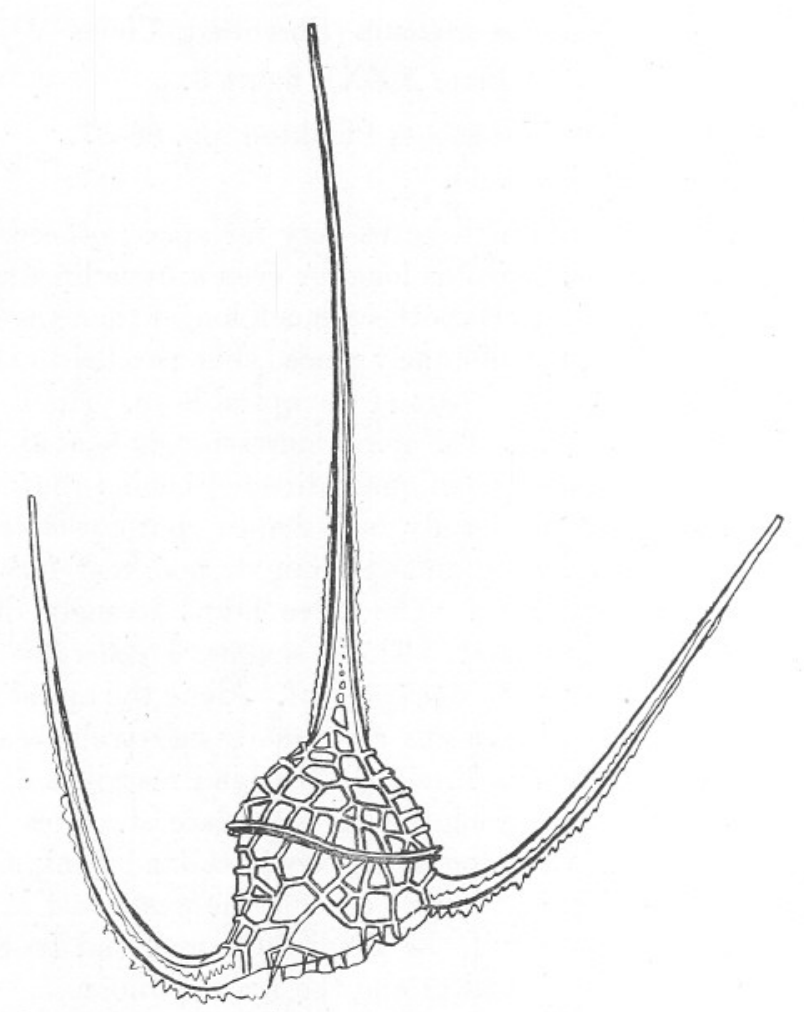

FIG. 51. Ceratium reticulatum (Pouchet) Cleve.

$\times$ 186. English Channel. From drawing by Mrs. Sexton.

reticulated by large crossing ridges. Proximal part of the hind horns usually with spiny lists and a large spiny list along the hind margin. Breadth $75-85 \mu$.

Warm-water species. Atlantic, Indian Ocean, Mediterranean, Florida Stream, English Channel.

Jörgensen recognises two forms: f. contorta Lemmermann (1900) and f. spiralis Kofoid (1907).

\section{Forms with no apparent Girdle.}

\section{Genus Podolampas Stein.}

Cell somewhat pear-shaped. In front drawn out into a more or less distinct apical horn that ends in an apical pore. Girdle not apparent, but probably fused with the adjacent precingular plates. In the ventral area lies the flagellar pore. Two strong antapical spines support transverse wings, the left being the continuation of the wing of the ventral 
area. The plates (Text-figure 53), as worked out by Kofoid (1909) for $P$. elegans, are 2 apicals, 1 anterior intercalary, 6 precingulars, 3 postcingulars, 4 antapicals, or $2^{\prime} 1 a 6^{\prime \prime} 3^{\prime \prime \prime} 4^{\prime \prime \prime \prime}$. The Northern members of the genus have not been so minutely investigated. Pores highly differentiated and correlated, with much internal differentiation and distribution and movements of the plasma.

Species :-Podolampas palmipes Stein, P. bipes Stein.

\section{Podolampas palmipes Stein (1883).}

Text-figure 52a.

Paulsen, 1908; Nordisches Plankton, p. 92.

Cell a long pear-shape, narrow, in front gradually narrowing into a slender horn. Left antapical spine much longer than the right. Wings of the spines fused with one another. Transverse seam (representing the girdle) often broad. Length ca. $80-100 \mu$.
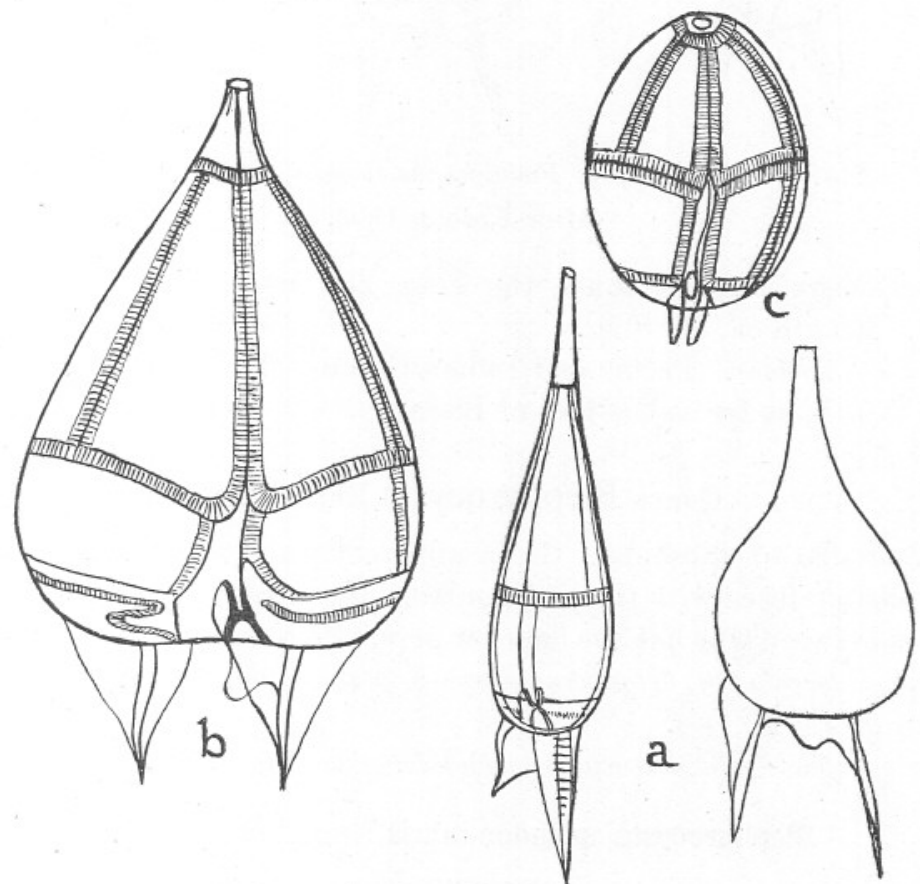

FIG. 52.

a. Podolampas palmipes Stein.

Left, after Stein. Right, after Schütt.

b. Podolampas bipes Stein. After Stein.

c. Blepharocysta splendor-maris Ehrenberg. After Stein. 
Sub-tropical, Atlantic species, often brought to the North by th' Gulf Stream.

Podolampas bipes Stein (1883).

Text-figure $52 \mathrm{~b}$.

Paulsen, 1908; Nordisches Plankton, pp. 92-93.

Cell broadly pear-shaped, in front slightly drawn out into a short horn.
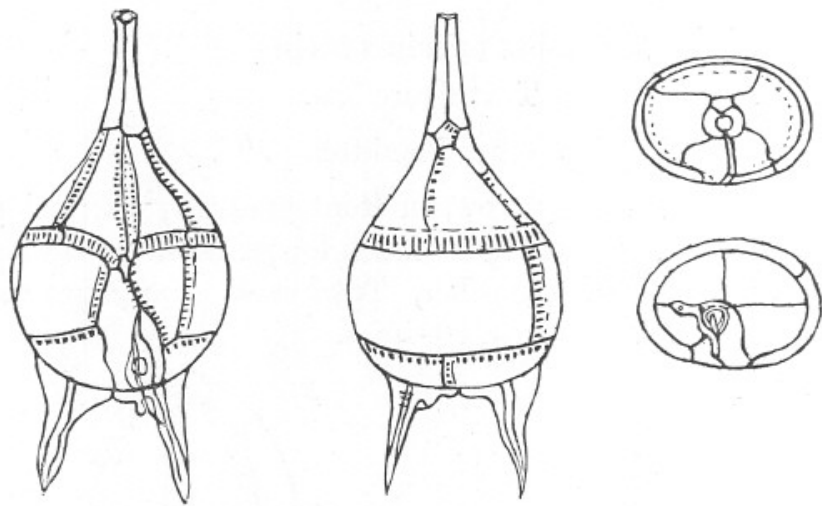

FIG. 53. Diagram of Podolampas elegans, showing plates.

After Kofoid, 1909.

Antapical spines about equal, the wings not fused. Intercalary striae broad. Length ca. $86-107 \mu$.

Tropical species. Pacific and Indian Oceans, Mediterranean. Seldom in the North, as far as the Bay of Biscay.

\section{Genus Blepharocysta Ehrenberg.}

Cell circular to ellipsoidal. Girdle apparently absent as in Podolampas, but probably fused with the precingulars. No furrow. Ventral area with furrows between which is the flagellar pore. Plate formula : 2 apicals, 1-2 anterior intercalaries, 6 precingulars, 3 postcingulars, 3 (?) apicals, or $2^{\prime} 1-2 a 6^{\prime \prime} 3^{\prime \prime \prime} 3^{\prime \prime \prime \prime}(?)$.

One spécies:-Blepharocysta splendor-maris Ehrenberg.

Blepharocysta splendor-maris Ehrenberg (1873).

Text-figure 52c.

Paulsen, 1908; Nordisches Plankton, p. 93.

Cell oval. Ventral area narrow. Oar-like processes conspicuous at the antapex. Theca punctured. Intercalary striae broad. Length ca.52$56 \mu$.

Warm seas. Stein records it from Heligoland. 


\section{APPENDIX \\ METHODS OF COLLECTING AND EXAMINING DINOFLAGELLATES}

To collect marine dinoflagellates a tow-net is used made of very fine silk (180 strands to the inch), the catch being rinsed into a glass jar and examined alive under the microscope. The naked forms do not bear preservation as a general rule, as they are excessively delicate; but those which possess a theca can be preserved in 5\% formalin or in Fleming's solution (by adding $10 \mathrm{cc}$. of strong Fleming solution-15 vols. $1 \%$ chromic acid, 4 vols. $2 \%$ osmic acid, 1 vol. glacial acetic acid-to $250 \mathrm{cc}$. of the sample).

A very good way of collecting the smaller species is to take a dip in the sea with a glass bottle and centrifuge part of it. A small hand centrifuge is quite sufficient for this purpose. The centrifuge tubes should be pointed at the ends, so that the bulk of the water may be poured away after centrifuging, leaving at the base of the tube the solid matter, including any dinoflagellates, which may then be pipetted off on to a glass slide. Each tube should hold about $10 \mathrm{cc}$., two or four being used at one time, and the sample centrifuged for from 5-10 minutes.

Special water bottles are used for procuring specimens of sea-water from various depths.

The water up estuaries may often be green or brown from the presence of dinoflagellates, which can then be collected in thousands by one dip with a cup or small jar.

On sandy beaches green or brown patches left by the tide should be examined for the sand-loving forms, which may occur in millions in such situations.

All material should be examined first alive whenever possible. This is the only satisfactory method for the naked forms, and examination of the samples should be undertaken as soon as possible after capture, as they are so delicate that the smallest accident kills them, and very often a specimen whilst under observation will collapse altogether.

For examination of the plates of the thecate forms the specimens should be treated with a suitable reagent to clear away the cell contents and, if possible, loosen the plates from one another. Eau de Javelle is good for this ; caustic potash is also used. Stains may be used with the 
potash or separately, aniline dyes being best. Personally I have found Trypan Blue, used alone, to be excellent. It stains the theca a clear blue and shows up the sutures between the plates in a perfect manner, especially in the thin-walled species such as Kryptoperidinium foliaceum, where no structure can be made out at all without treatment.

Simple cultures of holophytic dinoflagellates can be made in filtered sea-water, using Petri dishes or small flasks. Oxyrrhis can be cultured by giving it diatoms (Nitzschia) to eat. The colourless forms are usually more difficult, although small purely saprophytic species will live and multiply if given a small piece of decaying matter, such as a piece of mollusk.

Some species can be kept for days in a drop of water if prevented from drying up, and much of the life-history of such forms as Gymnodinium lunula can be followed through various phases of division. 


\section{LITERATURE}

ALLEN, W. E. 1922. Quantitative Studies on Inshore Marine Diatoms and Dinoflagellates of S. California.

Univ. Cal. Pub. Zoology, XXII, No. 5.

BAILEY, J. W. 1855. Notes on New Species and Localities of Microscopic Organisms.

Smithsonian Contr. Knowl., Washington, VII.

BARROWS, A. L. 1918. The Significance of Skeletal Variations in the Genus Peridinium.

Univ. Cal. Pub. Zoology, Vol. 18, No. 15.

BERGH, R. S. 1881. Der Organismus der Cilioflagellaten.

Morph. Jahrb., Leipzig, 7.

BORGERT, A. 1898. Beiträge zur Kenntnis des in Sticholonche zanclea und Acanthometridenarten vorkommenden Parasiten (Spiralkörper Fol. Amoebophrya Köppen).

Zs. Wiss. Zool., Leipzig, Bd. 63.

BREEMEN, P. J. vaN. 1905. Plankton van Noordzee en Zuiderzee. Tijdschr. Ned. Dierk. Ver., Helder, 1905.

BROCH, H. J. 1908. Planktonstudien an der Mündung der Ostsee im Juli, 1907.

Göteborg.

1910. (a) Die Peridinium-Arten des Nordhafens (val di Bora) bei Rovigno im Jahre 1909.

Arch. Protistenkunde, XX, Jena.

1910. (b) Das Plankton des schwedischen Expedition nach Spitzbergen, 1908.

K. Svenska Vet.-Ak. Handl., Stockholm, 45, No. 9.

BÜTSCHLI, O. 1873. Einiges über Infusorien.

Arch. Micr. Anat., IX, Bonn.

1885. Dinoflagellata (Bronn's Klassen und Ordnung des ThierReichs), Leipzig and Heidelberg.

CHATTON, E. 1920. Les Péridiniens parasites.

Arch. Zool., Paris, T. 59, March. 
CIENKOWSKI, L. 1881. Bericht über eine Exkursion ins weisse Meer im Jahre 1880 (in Russian).

Trav. Soc. Nat., Petrograd, XII, 1.

CLAPARĖDE AND LACHMANN. 1858-61. Études sur les infusoires et les rhizopodes, 2.

Mém. Inst. Nat. Genève, V, VI, VII.

CLEVE, P. T. 1897. A Treatise on the Phytoplankton of the Atlantic and its Tributaries.

Upsala.

\section{Notes on some Atlantic Plankton Organisms.}

K. Svenska Vet. Ak. Handl., Stockholm, 34, No. 1.

DADAY, J. von. 1888. Systematische Uebersicht der Dinoflagellaten des Golfes von Neapel.

Termt. Közl., Budapest, XI.

DANGEARD, P. 1923. Coloration vitale de l'appareil vacuolaire chez les Péridiniens.

C. R., Acad. Sci., Paris, T. 177, No. 20.

DIESING, K. M. 1866. Revision der Prothelminthen.

SitzBer. Ak. Wiss., Wien, 52.

DOGIEL, V. 1906. Beiträge zur Kenntnis der Peridineen.

Mitt. Zool. Stat, Neapel, Bd. 18.

DUJARDIN, F. 1841. Histoire Naturelle des Zoophytes, ete.

Suites à Buffon. (Paris, Roret.)

EHRENBERG, C. G. 1839. Üeber noch jetzt zahlreich lebende Thierarten der Kreidebildung und den Organismus der Polythalmien. Abh. Ak. Wiss., Berlin.

1840. Beobachtung von 274 Infusonienarten.

Bericht über Verhandl. d. Berliner Akad. d. Wissens.

1859. Über des Leuchten und über neue mikroskopische Leuchthiere des Mittelmeeres.

Monatsber. der Berliner Akad. d. Wissensch.

1873. Die das Funkeln und Aufblitzen des Mittelmeeres bewerkenden unsichtbar Kleinen Lebensformen.

Festschrift z. Feier d. 100 Jährigen Bestehens d. Ges. Naturforsch. Freunde zu Berlin, 1-4. 
ENTZ, G. 1906. Beiträge zur Kenntnis des Planktons.

Res. Wiss. Erf. des Balatonsees, Wien.

__ 1907. A Peridenéak szervezetéröl (Die Organisation der Peridinien).

Különlenyomat az állattani Közlemēnyak, Budapest, VI, 1.

_- 1921. Ueber die mitotische Teilung von Ceratium hirundinella.

Arch. Protistenkunde, Bd. 2, 3 ; Hft. 3.

— 1921-24. On Chain Formation in Ceratium hirundinella. Biologica Hungarica, Vol. I, f. 3.

FABRE-DOMERGUE. 1889. Note sur une nouvelle forme de Colpode (C. Henneguyi) et sur un Flagelle pelagique.

Ann. de Micrographie I, 1888-89.

FAURÉ-FREMIET, E. 1908. Études descriptive des Péridiniens et des infusoires Ciliés.

Ann. Sci. Nat. (Zool.), Paris, N.S., T. VII.

—_ and PUIGANDEAU, O. 1922. Le Microplankton de la Baie de la Croisic.

Bull. Soc. Zool., Paris, T. XLVII.

1923. Le Microplankton de la Baie de la Croisic, II, Genre Dinophysis Ehrbg.

Bull. Soc. Zool., Paris, T. XLVIII.

FORTI, A. 1922. Ricerche sur la flora pelagica (fitoplancton) di Quarto dei Mille (Mare Ligure).

R. Comitato Talassografico italiano, Mem. XCVII.

GOURRET, P. 1883. Sur les Péridiniens du Golfe de Marseille. Ann. Mus. Hist. Nat., Marseille; Zoology I.

GRAN, H. H. 1900. Hydrographical-biological Studies of the North Atlantic Ocean and the Coast of Nordland.

Rep. Norweg. Fisheries and Marine Investigations, I, No. 5

—_ 1902. Des Plankton des norwegischen Nordmeeres.

Rep. Norweg. Fisheries and Marine Investigations, II, No. 5.

- 1915. The Plankton Production in the North European Waters in the Spring of 1912.

Bull. Plank. for 1912. Cons. Perm. int. p. l'Explor. de la Mer Copenhagen.

HALL, R. P. 1924. Binary Fission in Oxyrrhis marina Dujardin.

Univ. Cal. Pub. Zoology, Vol. XXVI, No. 16. 
HERDMAN, W. A. 1911. On the Occurrence of Amphidinium operculatum Clap. and Lach., in vast quantity at Port Erin, Isle of Man.

J. Linn. Soc. Zool., London, Vol. XXXII, No. 212.

HERDMAN, C. E. 1921. Dinoflagellates and other Organisms causing Discoloration of the Sand.

Trans. Liverpool Biol. Soc., 35.

- 1922. Notes on Dinoflagellates and other Organisms causing Discoloration of the Sand at Port Erin.

Trans. Liverpool Biol. Soc., 36.

1923. Notes on Dinoflagellates and other Organisms causing Discoloration of the Sand at Port Erin, III.

Rep. Oceanography Department of the University of Liverpool.

- 1924. Notes on Dinoflagellates and other Organisms causing Discolouration of the Sand at Port Erin, IV.

Trans. Liverpool Biol. Soc., 38.

HIRASAKA, R. 1922. A Case of Discoloured Sea water.

Annot. Zool. Jap., Tŏkyo, Vol. X, Art. 15.

HOVASSE, R. 1923. Les Péridiniens intracellulaires-Zooxanthelles et Syndiniums - chez les Radiolaires coloniaux. Remarques sur la reproduction des Radiolaires.

Bul. Soc. Zool., Paris, T. XLVIII, 4-5.

HUTTFELD-KAAS, H. 1900. Die Limnetischen Peridineen in norwegischen Binnensee.

Vid. Skr. I, Math-naturw. Klasse, Christiania.

JOLLOS, V. 1910. Dinoflagellatenstudien.

Arch. Protistenkunde; Jena, Vol. XIX.

JORGENSEN, O. 1918. Occurrence of Amphidinium operculatum at Cullercoats.

Rep. Dove Marine Laboratory for 1918.

JÖRGENSEN, E. 1899. Protophyten und Protozoen im Plankton aus der Norwegischen Westküste.

Bergens Mus. Aarb., VI.

1911. (a) Die Ceratium Eine Kurze Monographie der Gattung Ceratium Schrank.

Biol. Supp. zur Intern. Rev. Hydrobiol., Leipzig, 2nd Ser. 
JÖRGENSEN, E. 1911. (b) Ceratium, in Résumé des Observations sur le Plankton des mers explorés, 1902-08.

Bull. trim. du Conseil perm. intern. p. l'explor. de la mer, II, Copenhagen.

- 1912 or 1913. Bericht über die von der schwedisches hydrographisch-biologischen Kommission in dem schwedischen Gewässern in den Jahren 1909-10 eingesammelten Planktonproben.

\section{Mediterranean Ceratia.}

Rep. on the Danish Oceanographical Expedition, 1908-10.

- 1921. Mediterranean Dinophysiaceae.

Rep. on the Danish Oceanographical Expedition, 1908-10.

KARSTEN, G. 1906. Das Phytoplankton des Atlantischen Oceans nach dem Material der deutschen Tiefsee Expedition, 1898-99.

Deutsche Tiefsee-Exp., 1898-99, Bd. II, 2 Teil.

KLEBS, G. 1912. Üeber Flagellaten und Algenähnliche Peridineen.

Verh. Naturhist, Heidelberg, N.F., Bd. 11.

KOFOID, C. A. 1907 (a) On Ceratium eugrammum and its related species.

Zool. Anz., Leipzig, Bd. XXXII, No. 1.

1907. (b) The Plates of Ceratium, with a Note on the Unity of the Genus.

Zool. Anz., Leipzig, Bd. XXXII, No. 7.

1907. (c) Dinoflagellates of the San Diego Region, III, Description of New Species.

Univ. Cal. Pub. Zoology, III, No. 13.

1907. (d) The Structure and Systematic Position of Polykrikos Bütsch.

Zool. Anz., Leipzig, Bd. XXXI, Nos. 9/10.

1907. (e) New Species of Dinoflagellates.

Bull. Mus. Comp. Zool., Cambridge, Mass., Vol. I, No. 6.

- 1909. (a) The Morphology of the Skeleton of Podolampas.

Arch. Protistenkunde, Jena, XVI.

1909. (b) On Peridinium Steinii Jörgensen, etc.

Arch. Protistenkunde, XVI.

1911. Dinoflagellata of the San Diego Region. IV. The Genus Goniaulax, etc.

Univ. Cal. Pub. Zoology, Vol. 8, No. 4. 
KOFOID, C. A. AND MICHENER. 1912. On the Structure and Relationships of Dinosphaera palustris (Lemm.).

Univ. Cal. Pub. Zoology, 11.

— AND SWEZY. 1921. The Free-living Unarmoured Dinoflagellata. Mem. of the Univ. of California, V.

KÖPPEN, N. 1894. Amoebophrya Stycholonchae nov. gen. et. sp. (Corps spiral de Fol).

Zool. Anz., XVII.

KÜSTER. 1908. Eine Kultivierbar Peridineae.

Arch. Protistenkunde, 11.

LEBOUR, M. V. 1917. The Peridiniales of Plymouth Sound from the Region beyond the Breakwater.

J. Mar. Biol. Ass., Plymouth, XI, 2.

1922. Plymouth Peridinians, I, II, III.

J. Mar. Biol. Ass., Plymouth, XII, 4.

— 1923. Plymouth Peridinians, IV.

J. Mar. Biol. Ass., Plymouth, XIII, 1.

LEMMERMANN, E. 1896. Zweiter Beitrag zur algenflora des Plöner Seengebietes.

Forsch. Biol. Stat. Plön., Part 4, Berlin.

1900. Peridiniales aquae dulcis et submarinae.

Beitz. z. Kennt. d. Planktonalgen. Hedwigia 39. Beibl. N. 4.

1902. Des Phytoplankton des Meeres. II Beitrag.

Abh. Naturw. Ver., Bremen, XVII.

1904. Das Plankton schwedischer Gewässer.

Ark. Botanik, Bd. 2, No. 2, Stockholm.

1910. Beitrage zur Kenntnis der Plankton.

Algen. XXX. Peridinium trochoideum (Stein), Lemm. nob.

Arch. Hydrobiol., Stuttgart, V. 4.

LEVANDER, K. M. 1894. Peridinium catenatum, n.sp. Eine Kettenbildende Peridinee im Finnischen Meeresbusen. Acta Soc., Fauna Flora, Fenn., Vol. X, 9.

- 1894. Materialen zur Kenntnis der Wasserfauna in der Umgebung von Helsingfors, mit besonderer Berucksichtigung der Meeresfauna. I. Protozoa.

Acta Soc., Fauna Flora, Fenn., Vol. XII, 2. 
LEVANDER, K. M. 1902. Eine neue farblose Peridinium Art. Acta Soc., Fauna Flora, Fenn., No. 11, 28 bd.

LINDEMANN, E. 1923. (a) Der Bau der Hülle bei Heterocapsa und Kryptoperidinium foliaceum (Stein), n.nom. (Advance reprint.)

(Zugleich eine vorläufige Mittheilung.) Botanisches Archiv.

— 1923. (b) Ueber Peridinean einiger Seen Suddeutschlands und des Alpengebietes.

Schriften für Süsswasser-und Meereskunde, Hft. 10.

1924. Peridineen der Konstantinopeler Gewässer.

Botanisches Archiv., 1924, Bd. V, Hft. 34 (Feb.).

LOHMANN, H. 1908. Untersuchungen zur Feststellung des vollständigen Gehaltes des Meeres am Plankton.

Wiss. Meeres, Kiel, N.F., X.

MACARTNEY, J. 1910. Observations upon Luminous Animals.

Phil. Trans. R. Soc., London, 1910, Pt. I.

MANGIN, L. 1911. Modifications de la Cuirasse chez quelques Péridiniens.

Intern. Rev. Hydrobiol., Leipzig, Bd. IV.

1912. Phytoplancton de la croissance du René dans l'Atlantique. Ann. Inst. Oceanog., Paris.

1913. Sur la flore planctonique de la rade de St. Vaast-la-Hougue, 1908-1912.

Nouv. Arch. Mus. Hist. Nat., Paris, $5^{e}$ Série. V.

MARSHALL, S. M. 1925. On Protoerythropsis vigilans, n.sp.

Q. J. Microsc. Sci., London, N.S. No. 274, Vol. 69, Pt. II.

MERESCHKOWSKY, C. 1879. Studien über Protozoen des Nördlichen Russland.

Arch. mik. Anat., Bonn, XVI.

MEUNIER, A. 1910. Microplankton des mers de Barents et de Kara. Duc d'Orleans : Campagne Arctique de 1907.

1919. Microplancton de la Mer Flamande. 3. Les Péridiniens.

Mem. Mus. Roy. Hist. Nat. Bruxelles 8, No. 1, Brussels.

MÜLLER, JOH. 1841. Ueber den Bau des Pentacrinus caput Medusae. Abhandl. Ak. Wiss., Berlin.

MÜLLER, O. F. 1777. Zoologiae danicae prodromus. Hauniae.

— 1786. Animalcula, Infusoria fluviatilia et marina; opus posthumum enra O. Fabricii. Hauniae. 
MURRAY, J., AND HJORT, J. 1912. The Depths of the Ocean. London.

MURRAY, G., AND WHITTING, F. G. 1899. New Peridiniaceae from the Atlantic.

Trans. Linn. Soc., London, 2 Sec., Bot. V.

OSTENFELD, C. H. 1901. Phytoplankton fra det Kaspike Hav.

Videns. Medd. nat. For., Kjöbenhavn.

- 1903. Phytoplankton from the Sea around the Faroes.

Botany of the Faroes.

—— 1906. Plankton Vegetal. In. Catalogue des espèces, etc. Conseil permanent, etc.

Publications de Circonstance, 33. Copenhagen.

- 1908. The Phytoplankton of the Aral Sea and its affluents, etc.

St. Petersburg.

- 1915. A List of Phytoplankton from the Boeton Strait, Celebes.

Dansk. Bot. Archiv. II, No. 4, Copenhagen.

PASCHER, A. 1923. Kleinere Mitteilungen. Neue oder wenig bekannte Protistein VIII. Neue oder wenig bekannte Flagellaten VII. Arch. Protistenkunde. Jena, Bd. 46, Hft. 1.

PAULSEN, OVE. 1904. Plankton investigations in the Waters round Iceland in 1903.

Medd. Havunders., Kjöbenhavn, Ser. Plankton, Bd. 1, No. 1.

- 1905. On some Peridiniae and Plankton Diatoms. Ibid., Bd. I, No. 3.

- 1907. The Peridiniales of the Danish Waters. Ibid., Bd. I, No. 5.

— 1908. Nordisches Plankton, XVIII. Peridiniales.

— 1911. Marine Plankton from the East Greenland Sea. III. Peridiniales.

Medd. Gronl., Kjöbenhavn, XLIII.

- 1912. Peridiniales Ceterae.

Bull. Trim, etc., publié par le bureau du conseil perm. int. p. l'expl. de la Mer, résumé planktonique, Part 3, Copenhagen.

PAVILLARD, J. 1905. Recherches sur la flore pélagique de l'étang de Thau.

Trav. Inst. Bot. Univ. Montpellier, Cette. 
PAVILlaRD, J. 1912. A propos du Diplopsalis lenticula Bergh.

C.R. Acad. Sci., Paris, 155. July 8th.

1913. Le Genre Diplopsalis Bergh et les Genres voisins.

Montpellier, July, 1913.

1916. Recherches sur les Péridiniens du Golfe de Lion.

Trav. Inst. Bot. Univ., Montpellier, Cette, S. mixte, Mem 4. March, 1916.

1917. (a) Un Flagelle pélagique aberrant, le Pelagorhynchus marinus.

C.R. Acad. Sci., Paris, T.164. Jan. 29.

1917. (b) Protistes nouveaux un peu connus du Plankton Méditerraneen.

Ibid. June 11.

1921. Sur le Gymnodinium pseudonoctiluca Pouchet.

Ibid., T. 172. April 4.

1922. Pronoctiluca et Noctiluca.

Bull. Soc. Bot. France, 69, 4me Série, T. XXII.

PENARD, E. 1891. Les Peridiniaceae du Leman.

Bull. Soc. Bot. Genève 6, 1891.

POUCHET, G. 1883. Contribution à l'histoire naturelle des cilioflagelles.

J. Anat. Physiol., Paris.

- 1885. (a) Novelle Contribution à l'histoire des Péridiniens marins. Ibid.

1885. (b) Troisième Contribution à l'histoire des Péridiniens.

Ibid.

1887. Quatrième Contribution à l'histoire des Péridiniens.

Ibid.

— 1892. Cinquième Contribution à l'histoire des Péridiniens. Ibid.

1894. Plankton (Voyage de La Manche à l'île Jan-Mayen et au Spitzbergen). Paris.

SAVILLE-KENT. 1880-82. A Manual of the Infusoria, London.

SCHILLER, JOS. 1918. Kleinere Mitteilungen Ueber neue Prorocentrum und Exuviella arten aus der Adria.

Arch. Protistenkunde, Bd. 38, Hft. 2. 
SCHILLING, A. J. 1913. Dinoflagellatae (Peridineae) Die Süsswasser Flora Deutschlands. Hft. III, Jena.

SCHÜTT, FR. 1895. Die Peridineen den Plankton Expedition I.

Ergebnisse der Plankton-Expedition, Kiel and Leipzig.

- 1896. Peridiniales.

Engler u. Prantl. Die Nat. Pflanzenfam. I, B., Leipzig.

STEIN, F. von. 1883. Der Organismus der Infusionstiere III, 2. Die Naturgeschichte der Arthrodelen Flagellaten.

Leipzig.

STORROW, B. 1913. Faunistic Notes.

Rep. Dove Marine Laboratory for 1912.

VANHÖFFEN, E. 1897. Die Fauna und Flora Grönlands.

(Grönland Exp. der Gesellsch. für Erdkunde zu Berlin. II.)

WEST, G. S. 1916. Algae, Vol. I, including Peridinieae.

Cambridge Botanical Handbooks.

WHITEHEAD. 1914. Notes.

Rep. Dove Marine Laboratory for 1913.

WOLOSZYNSKA, J. 1917. New Species of Peridineae, with remarks on the structure of the outer Membrane in Gymnodinium and Glenodinium.

Bull. Acad. Sci., Gracovie, 57, S.B.

WULFF, A. 1916. Ueber des Kleinplankton der Barentssee.

Wiss. Meeresunters., Kiel, N.F., Bd. XIII, Abt. Heligoland, Heft 1.

ZEDERBAUER, E. 1904. Geschlechtliche und ungeschlechtliche Fortpflanzung von Ceratium hirundinella.

Bericht d. deutschen Bot. Gesellsch, XXII, Berlin. 


\section{PLATES}




\section{PLATE I}

FIg. 1. Exuviella marina Cienk.

(a b) $36 \mu$ long, Plymouth Sound. (c) $42 \mu$ long, Port Erin, Isle of Man. (d) Port Erin, Isle of Man, encysted and dividing.

FIG. 2. Exuviella compressa (Bailey). Ostenfeld. $34 \mu$ long, Plymouth Sound.

FIG. 3. Exuviella perforata Gran.

$22 \mu$ long, Plymouth Sound. (a) side view. (b) ventral view. (c) anterior end, much enlarged.

FIg. 4. Exuviella apora Schiller.

Yealm Estuary, near Plymouth. $(a)$ and $(b) 16 \mu$ long ; side and ventral views. (c) $22 \mu$ long. Alive.

FIG. 5. Prorocentrum micans Ehrenberg.

$37 \mu$ long, Plymouth Sound. (a) side view. (b) dividing. (c) right valve, showing sculpture.

Fı́̆. 6. Oxyrrhis marina Dujardin,

$33 \mu$ long. From culture in Plymouth Laboratory. $(a)$ ventral. (b) side view. (c) from below. (d) dividing. (e) containing Nitzschia. 
[ 175 ]

'PLATE ]
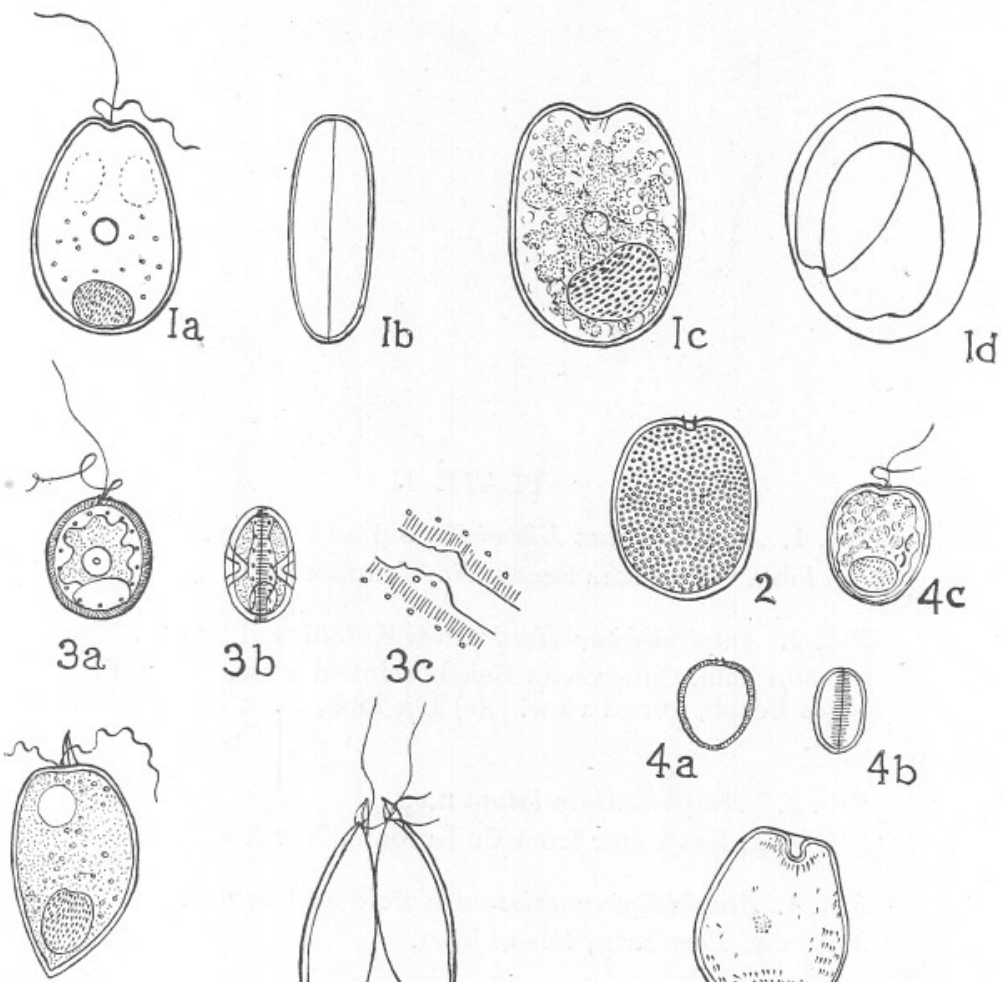

$5 a$
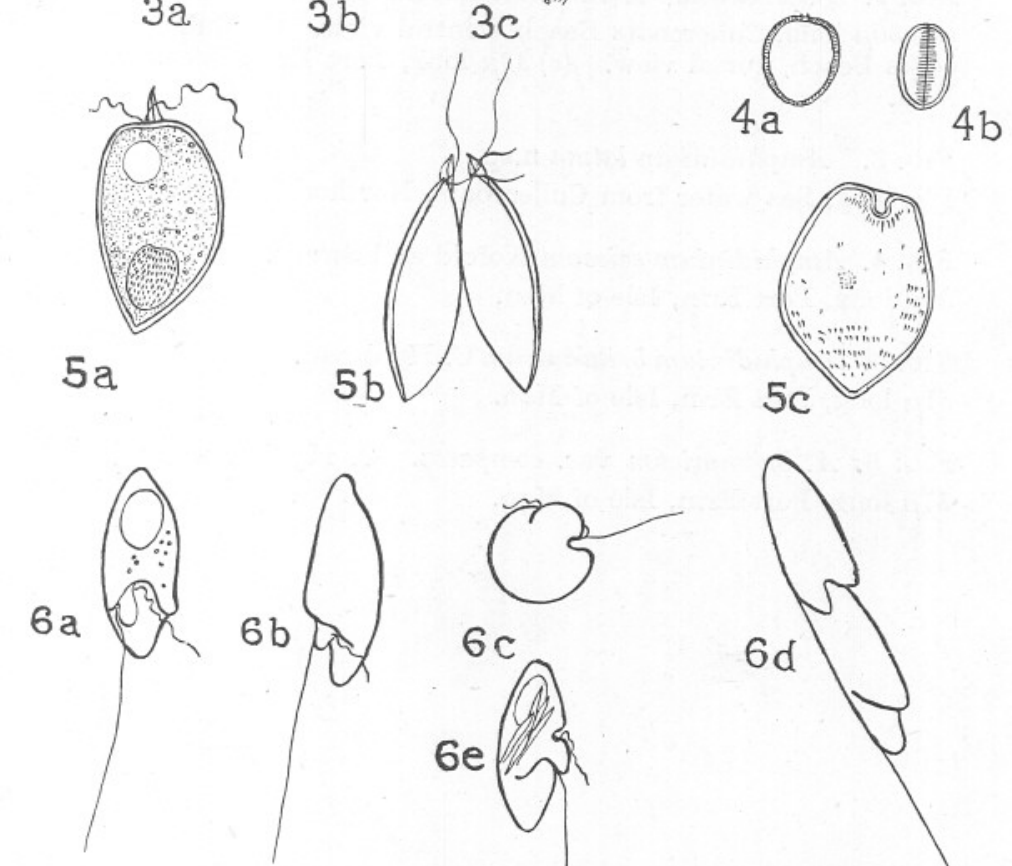

쏘
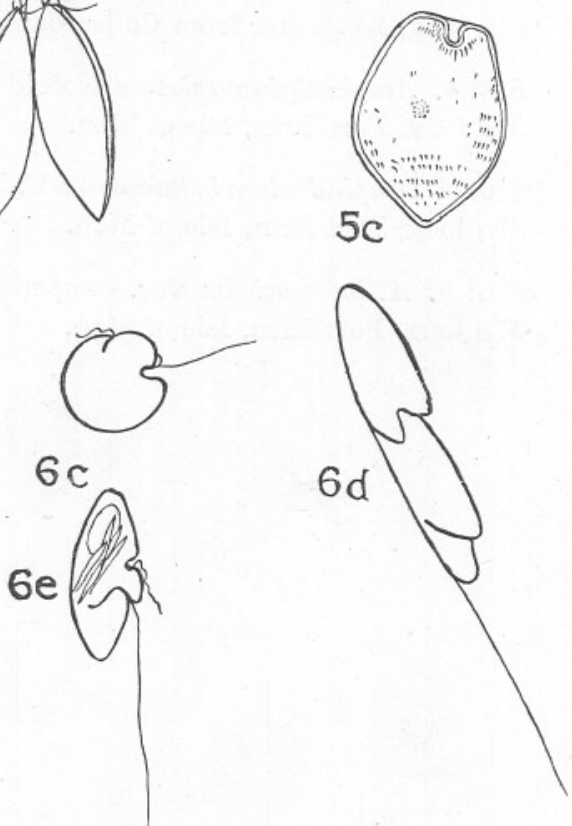


\section{PLATE 11}

FIg. 1. Amphidinium Klebsi Kofoid and Swezy. $36 \mu$ long, Cullercoats Beach, Northumberland.

FIG. 2. Amphidinium Herdmanni Kofoid and Swezy. (a) $30 \mu$ long, Cullercoats Beach, ventral view. (b) Cullercoats Beach, dorsal view. (c) $33 \mu$ long, Port Erin, Isle of Man.

FIG. 3. Amphidinium latum n.sp.

$19 \mu$ long, Sea water from Cullercoats, Northumberland.

FIG. 4. Amphidinium scissum Kofoid and Swezy. $56 \mu$ long, Port Erin, Isle of Man.

FIG. 5. Amphidinium britannicum C. Herdman. $51 \mu$ long, Port Erin, Isle of Man.

FIG. 6. A. britannicum var. compacta. C. Herdman. $37 \mu$ long, Port Erin, Isle of Man. 
[ 177 ]

PLATE II
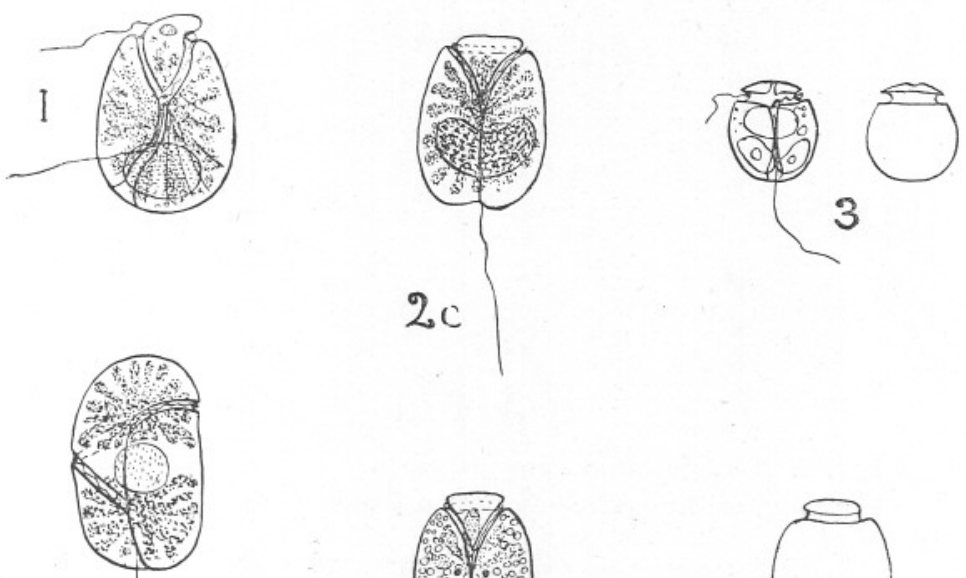

6
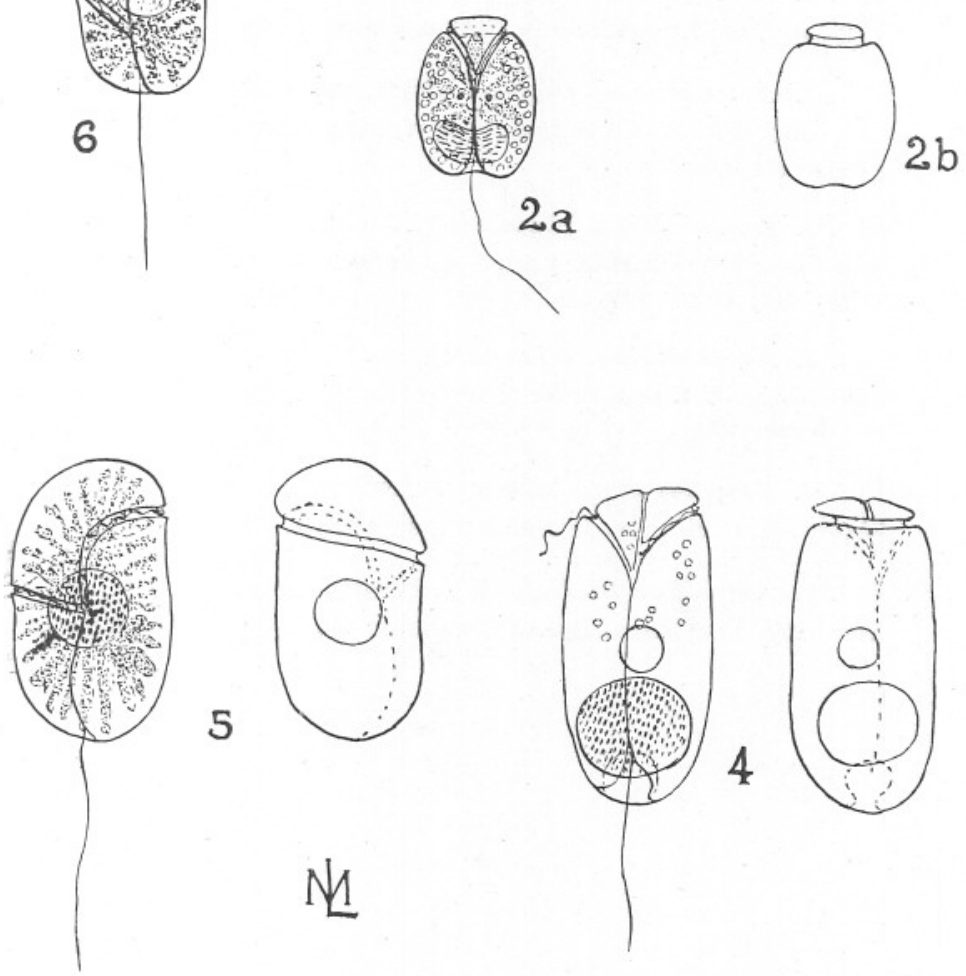


\section{PLATE III}

FIG. 1. Amphidinium scissoides n.sp.

$70 \mu$ long, off Eddystone Grounds, English Channel.

Fig. 2. Amphidinium crassum Lohmann.

$28 \mu$ long, Plymouth Sound. (a) ventral view. (b) dorsal view. (c) side view.

FIG. 3. Amphidinium phaeocysticola n.sp.

$42 \mu$ long, Plymouth Sound. (a) ventral view. (b) dorsal view. (c) side view.

FIG. 4. Amphidinium pelagicum n.sp.

$84 \mu$ long, 5 miles S.W. Plymouth. (a) ventral view. (b) dorsal view. (c) side view.

FIG. 5. Amphidinium eludens C. Herdman.

$30 \mu$ long, Port Erin, Isle of Man, side view.

FIG. 6. Amphidinium Kofoidi C. Herdman.

$29 \mu$ long, Port Erin, Isle of Man, side view. 
[ 179 ]

PLATE III
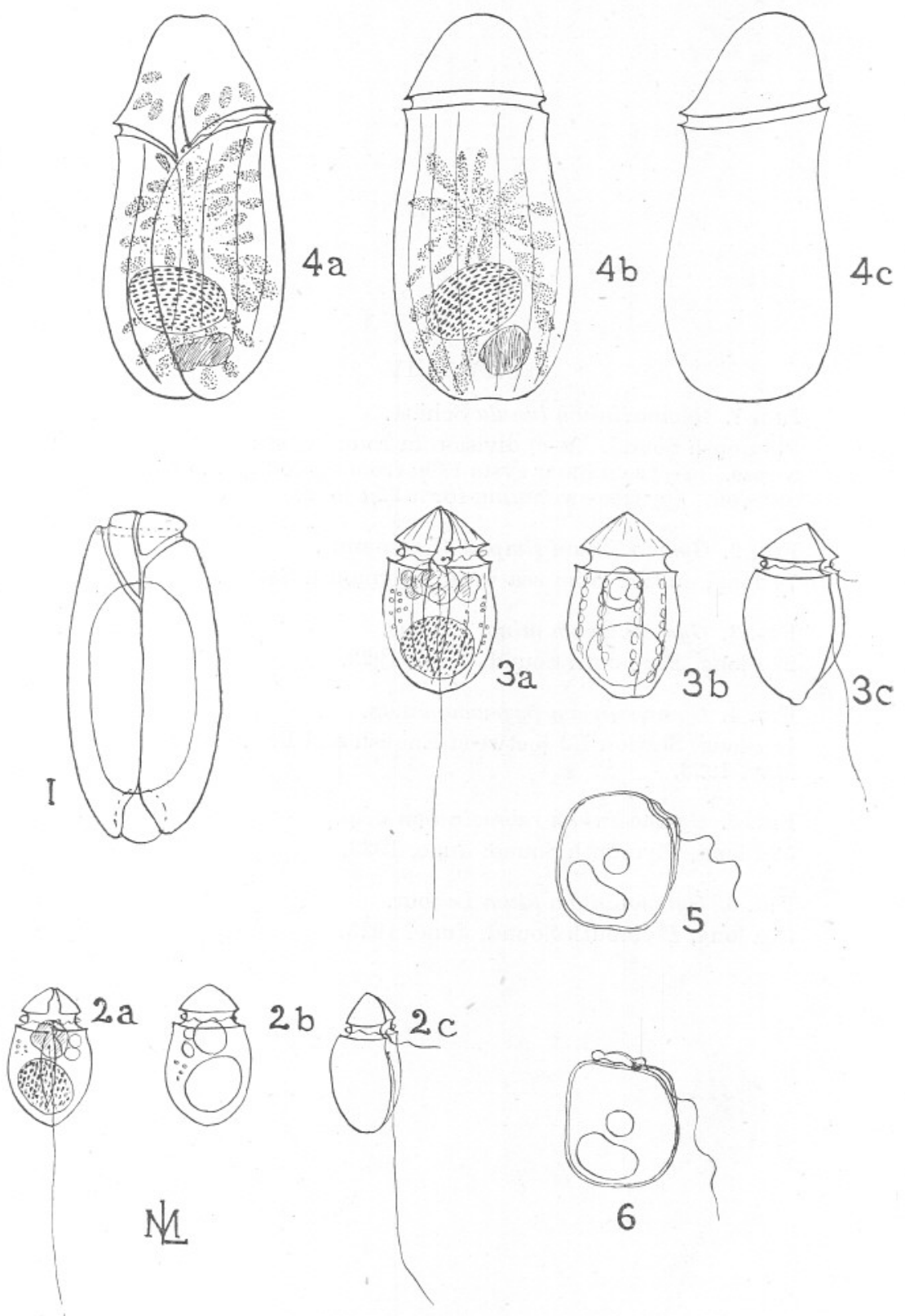


\section{PLATE IV}

FIG. 1. Gymnodinium lunula Schütt.

Plymouth Sound. $(a-c)$ division in round eyst : cyst $80 \mu$ across. $(d-f)$ semilunar cysts $130 \mu$ from tip to tip, showing division. $(g)$ free-swimming form $22 \mu$ long.

Fig. 2. Gymnodinium simplex (Lohmann).

$7 \mu$ long, culture from sea water, Plymouth Sound.

FIG. 3. Gymnodinium minor Lebour.

$28 \mu$ long, Plymouth Sound, June, 1923.

FIG. 4. Gymnodinium pygmaeum n.sp.

$14 \mu$ long, Station E2 (between English and French coast), May, 1923.

FIG. 5. Gymnodinium rubrocinctum n.sp.

$52 \mu$ long, Plymouth Sound, June, 1923.

FזG. 6. Gymnodinium filum Lebour.

5l $\mu$ long, Plymouth Sound, June, 1923. 
[ 181 ]

PLATE IV
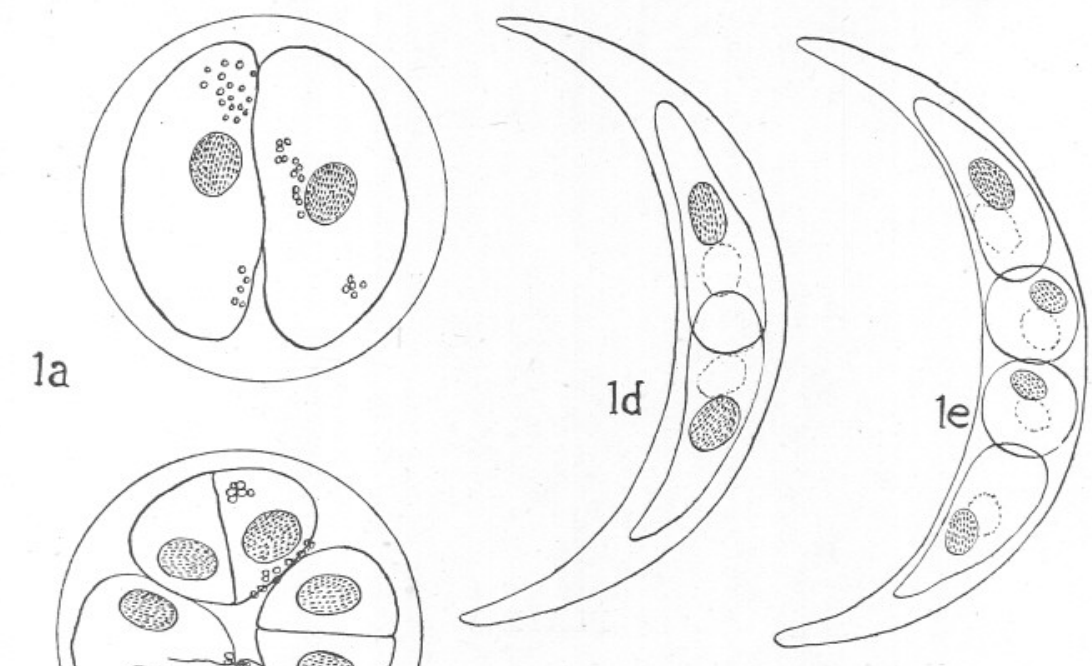

$1 \mathrm{~b}$
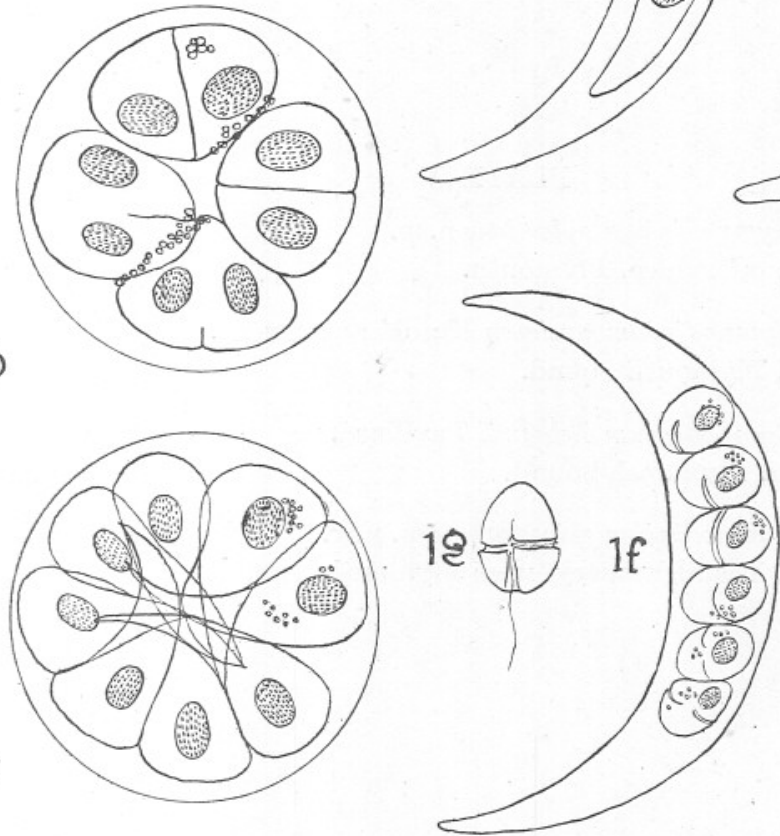

(ii)

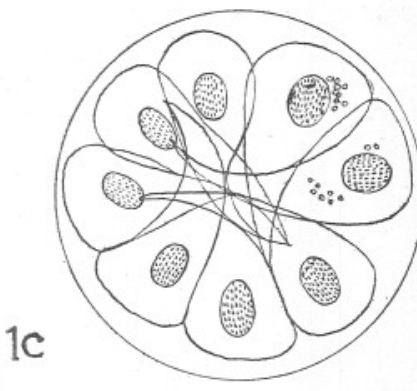

2
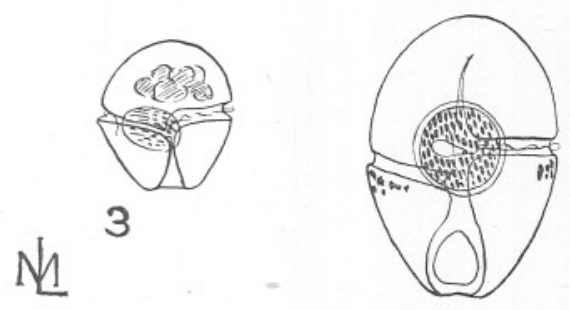

5
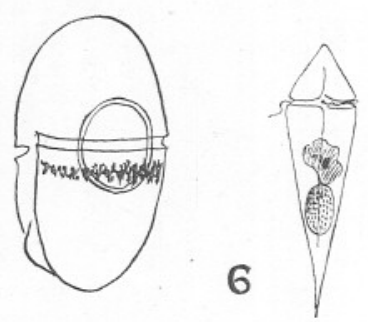
[ 182 ]

PLATE V

FIG. 1. Gymnodinium splendens n.sp.

$54 \mu$ long, off Penlee, Plymouth.

Fig. 2. Gymnodinium conicum Kofoid and Swezy. $60 \mu$ long, Plymouth Sound.

FIG. 3. Gymnodinium Lebourii Pavillard. $100 \mu$ long, Plymouth Sound.

FIG. 4. Gymnodinium minutum nom. nov. $14 \mu$ long, Yealm Estuary, near Plymouth. 
[ 183 ]

PLATE V
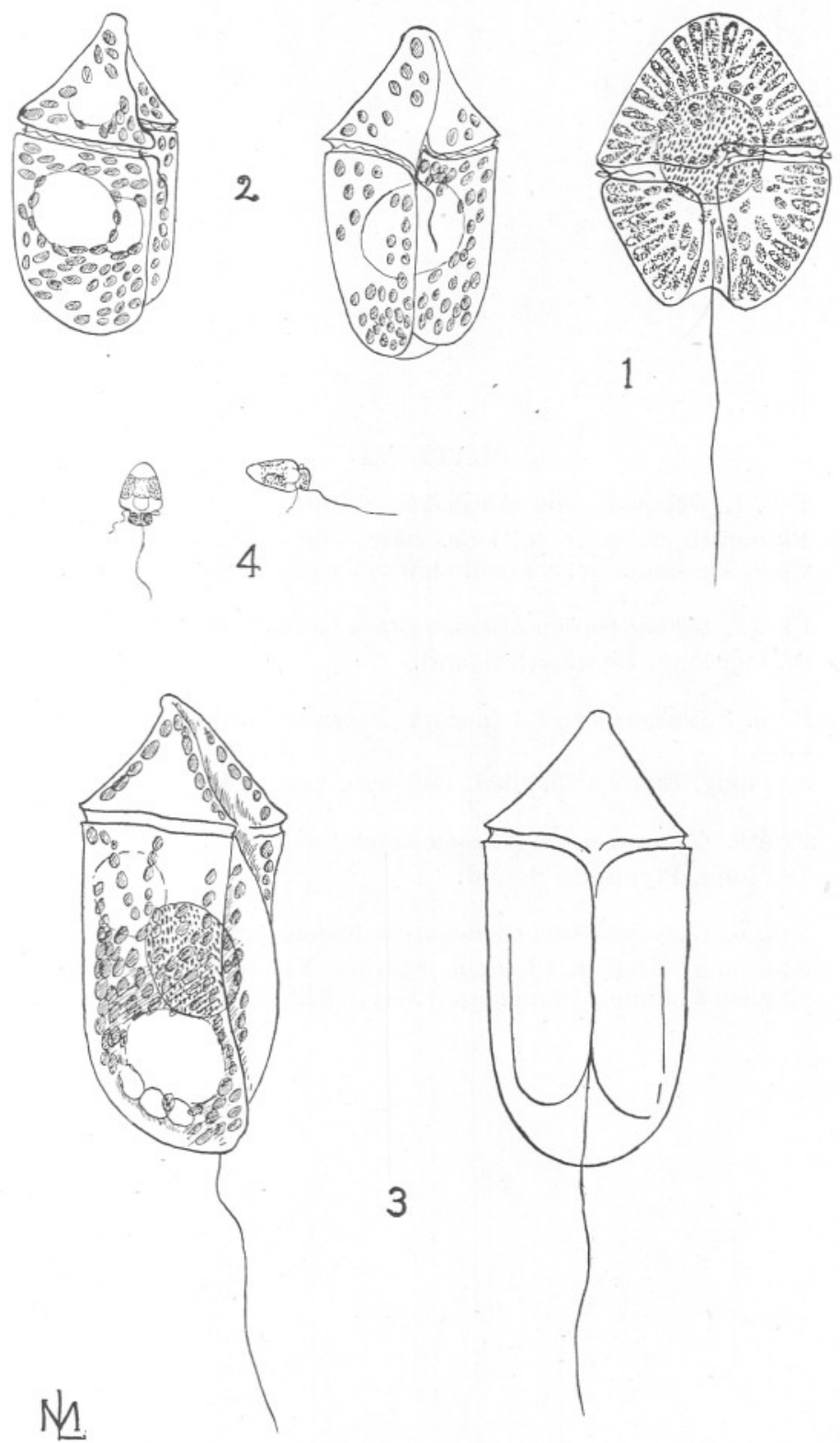


\section{PLATE VI}

FIG. 1. Gymnodinium rhomboides Schütt.

Plymouth Sound. (a) side view, $40 \mu$ long. (b) dorsal view, $30 \mu$ long. (c) ventral view, enclosed in cyst $42 \mu$ long,

FIG. 2. Gymnodinium heterostriatum Kofoid and Swezy. ca. $40 \mu$ long, Plymouth Sound.

Figs. 3 (variety) and 4 (normal). Gymnodinium hyalinum n.sp.

$39 \mu$ long, English Channel, Polperro, Looe. May, 1923.

FIG. 5. Gymnodinium achromaticum Lebour.

$78 \mu$ long, Plymouth Sound.

Fig. 6. Gymnodinium abbreviatum Kofoid and Swezy.

$84 \mu$ long, English Channel, Station N1, at entrance to English Channel, 10 metres. May, 1922. 
[ 185 ]

PLATE VI
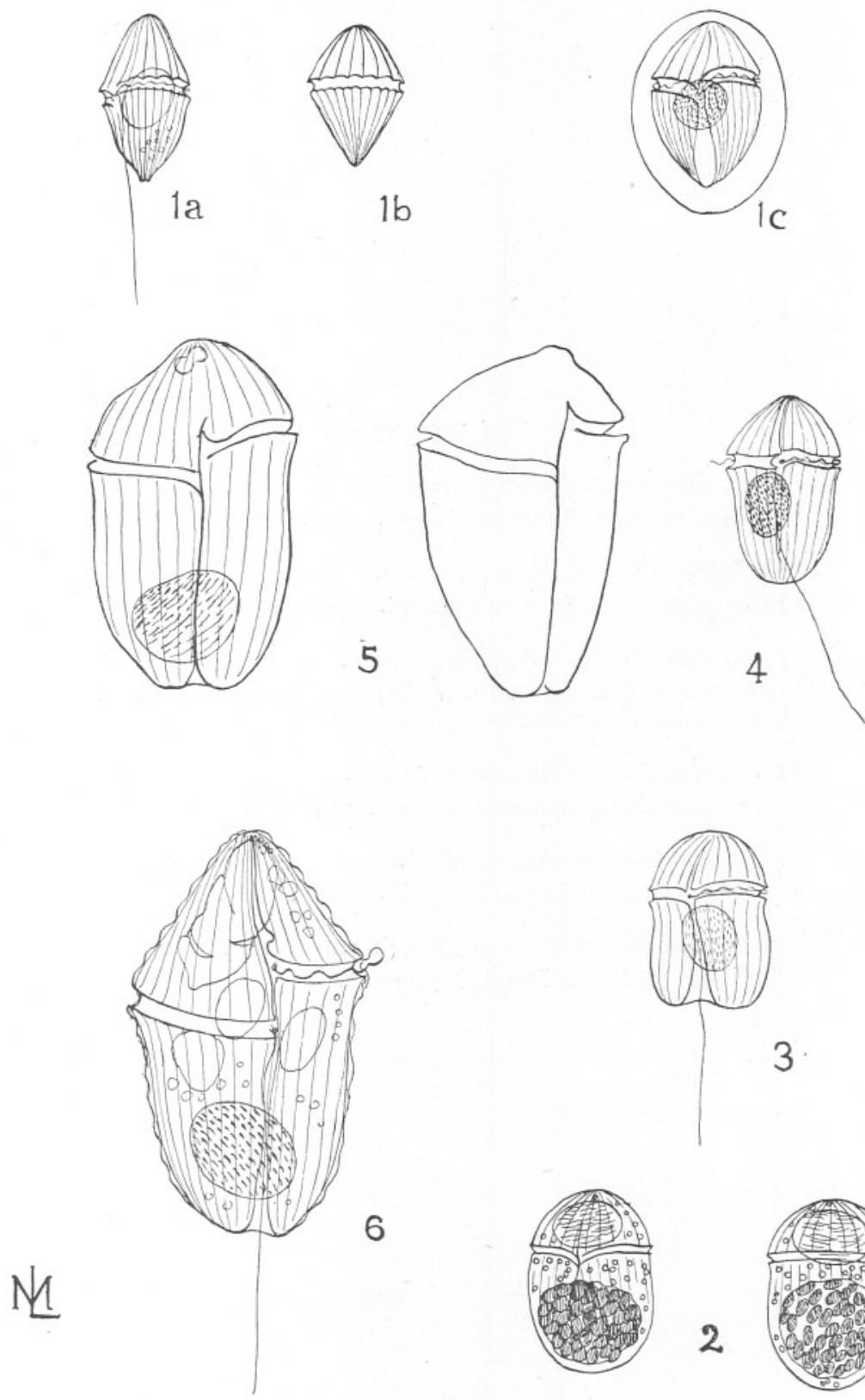

6
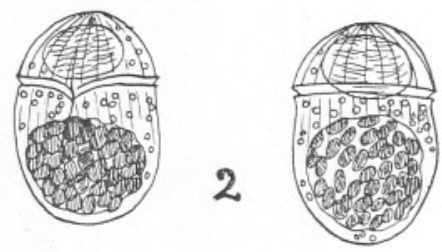


\section{PLATE VII}

FIG. 1. Gyrodinium falcatum Kofoid and Swezy. $84 \mu$ long, outside Plymouth Sound. Dec., 1921.

FIG. 2. Gyrodinium lingulifera n.sp.

$39 \mu$ long, outside Plymouth Sound. May, 1923.

FIG. 3. Gyrodinium calyptoglyphe n.sp.

Plymouth Sound. July, 1923. (a) $30 \mu$ long, ventral view. (b) $28 \mu$ long, side view.

FIG. 4. Gyrodinium glaucum (Lebour).

$56 \mu$ long, off Eddystone Grounds. May, 1923.

FIG. 5. Gyrodinium bepo (Schütt).

$56 \mu$ long, Cawsand Bay, Plymouth. July, 1920.

FIG. 6. Gyrodinium britannia Kofoid and Swezy. $168 \mu$ long, off Rame Head, Plymouth. 
[ 187 ]

PLATE VII
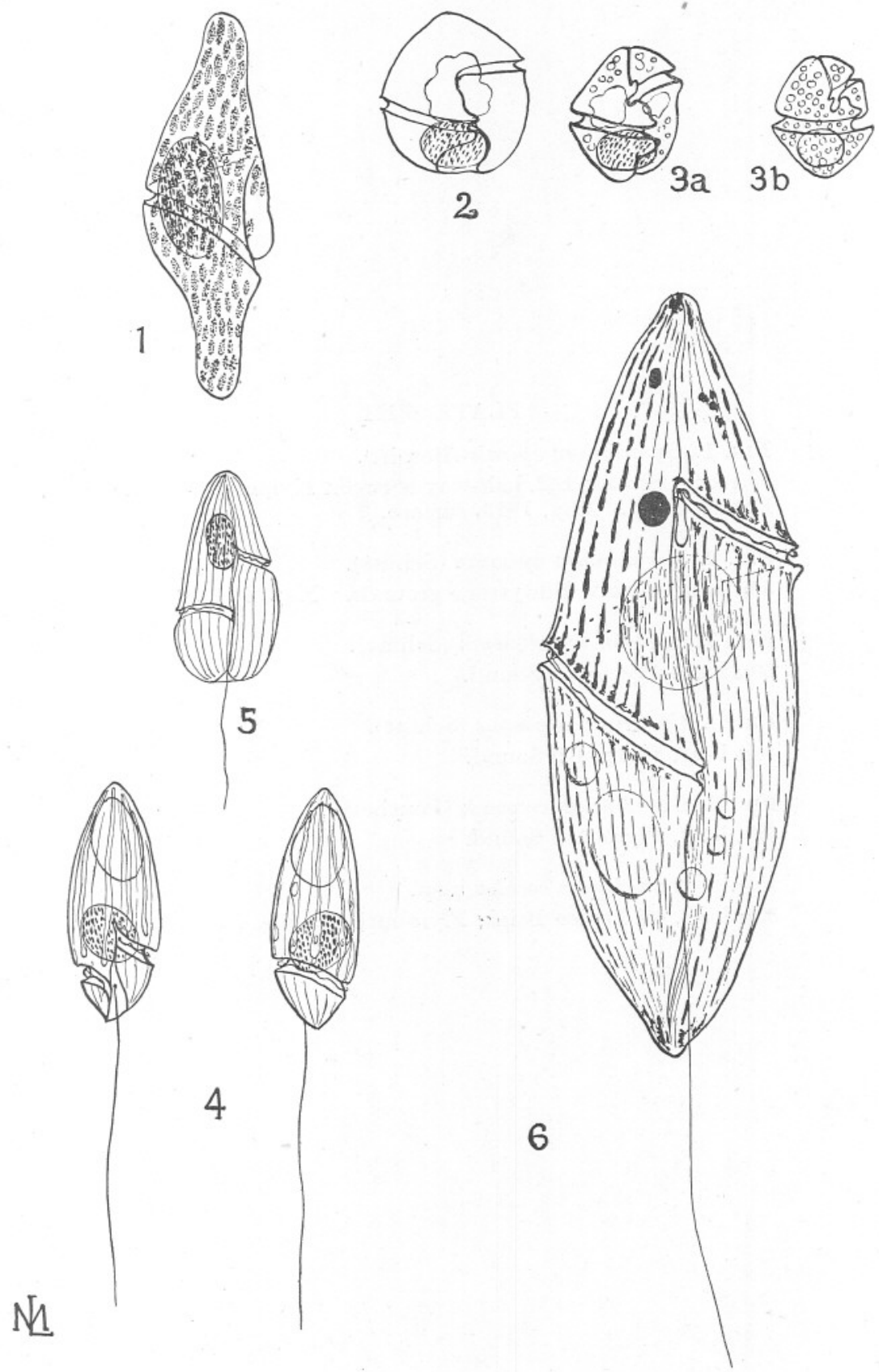


\section{PLATE VIII}

FIG. 1. Gyrodinium spirale (Bergh.).

$98 \mu$ long, Station E.2, half-way between Plymouth and the French coast. May, 1923, surface.

FIG. 2. Gyrodinium opimum (Schütt).

$50 \mu$ long, outside Eddystone grounds. May, 1923.

FIG. 3. Gyrodinium obtusum (Schütt).

$50 \mu$ long, Plymouth Sound.

FIG. 4. Gyrodinium pingue (Schütt).

$45 \mu$ long, Plymouth Sound.

FIG. 5. Gyrodinium crassum (Pouchet).

$75 \mu$ long, Plymouth Sound.

FIG. 6. Gyrodinium cochlea n.sp.

55 $\mu$ long, off Penlee Point, Plymouth. June, 1923. 
[ 189 ]

PLATE VIII

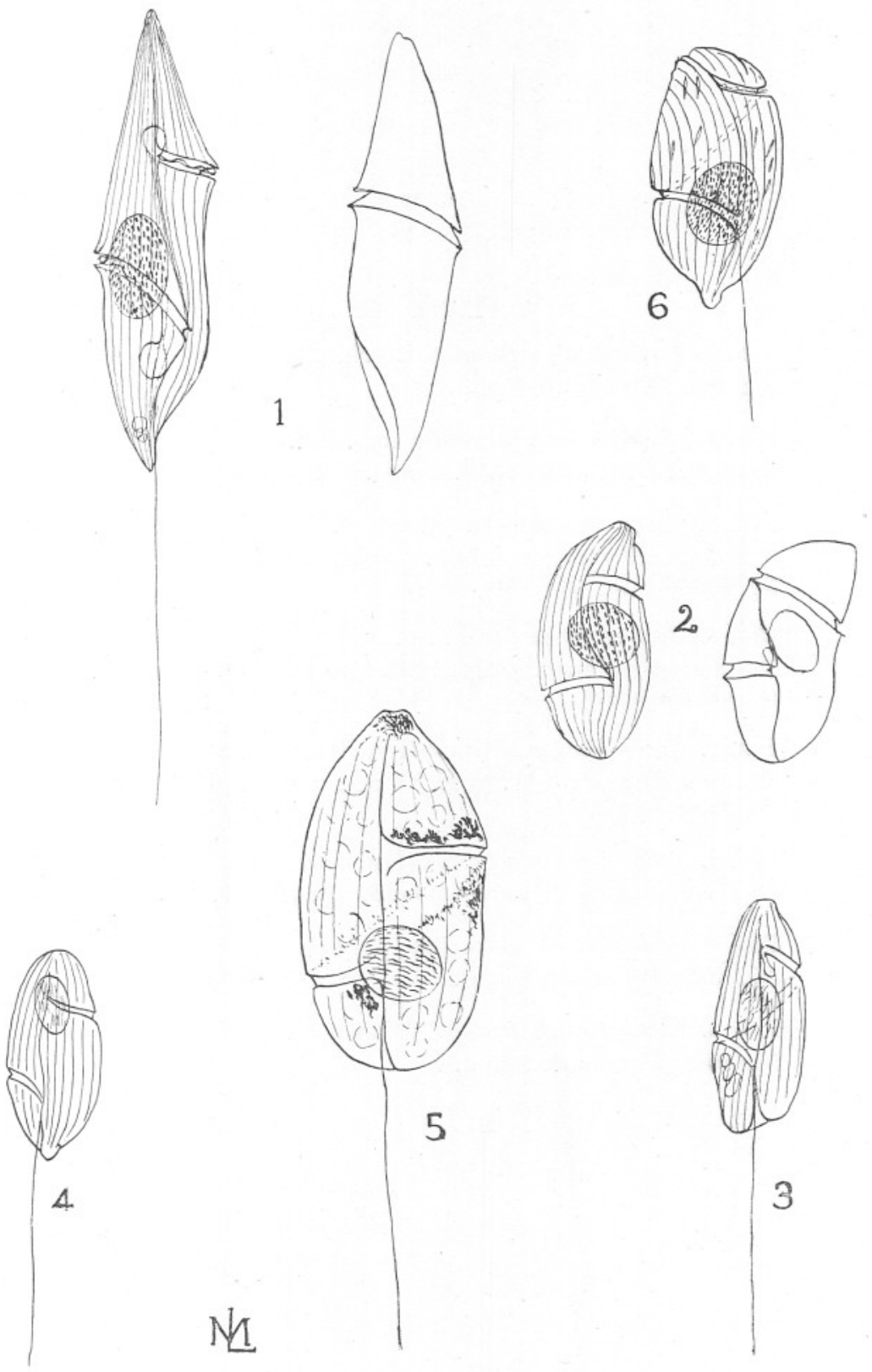




\section{PLATE IX}

FIG. 1. Cochlodinium Schuetti Kofoid and Swezy. $52 \mu$ long, Plymouth Sound.

FIG. 2. Cochlodinium helicoides nom. nov.

$36 \mu$ long, Eddystone, N.W. 1 mile. May, 1922.

FIG. 3. Cochlodinium helix (Pouchet).

$32 \mu$ long, Plymouth Sound. July, 1923. (a) ventral. (b) dorsal. (c) side view.

FIG. 4. Cochlodinium pupa n.sp.

$39 \mu$ long, Plymouth. July, 1923. (a) and (c) side views. (b) ventral view.

FIG. 5. Cochlodinium vinctum Kofoid and Swezy.

$42 \mu$ long, Eddystone W. by N. 3 miles, surface. $(a)$ ventral. (b) dorsal view.

FIG. 6. Cochlodinium achromaticum n.sp.

$43 \mu$ long, outside Plymouth Sound. May, 1923.

FIG. 7. Cochlodinium pulchellum Lebour.

$35 \mu$ long, Plymouth Sound.

FIG. 8. Cochlodinium Brandti (Wulff).

$56 \mu$ long, Plymouth Sound. 


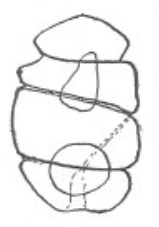

$4 a$
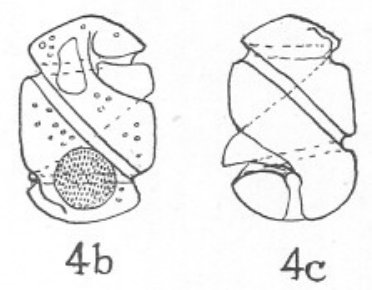

PLATE IX
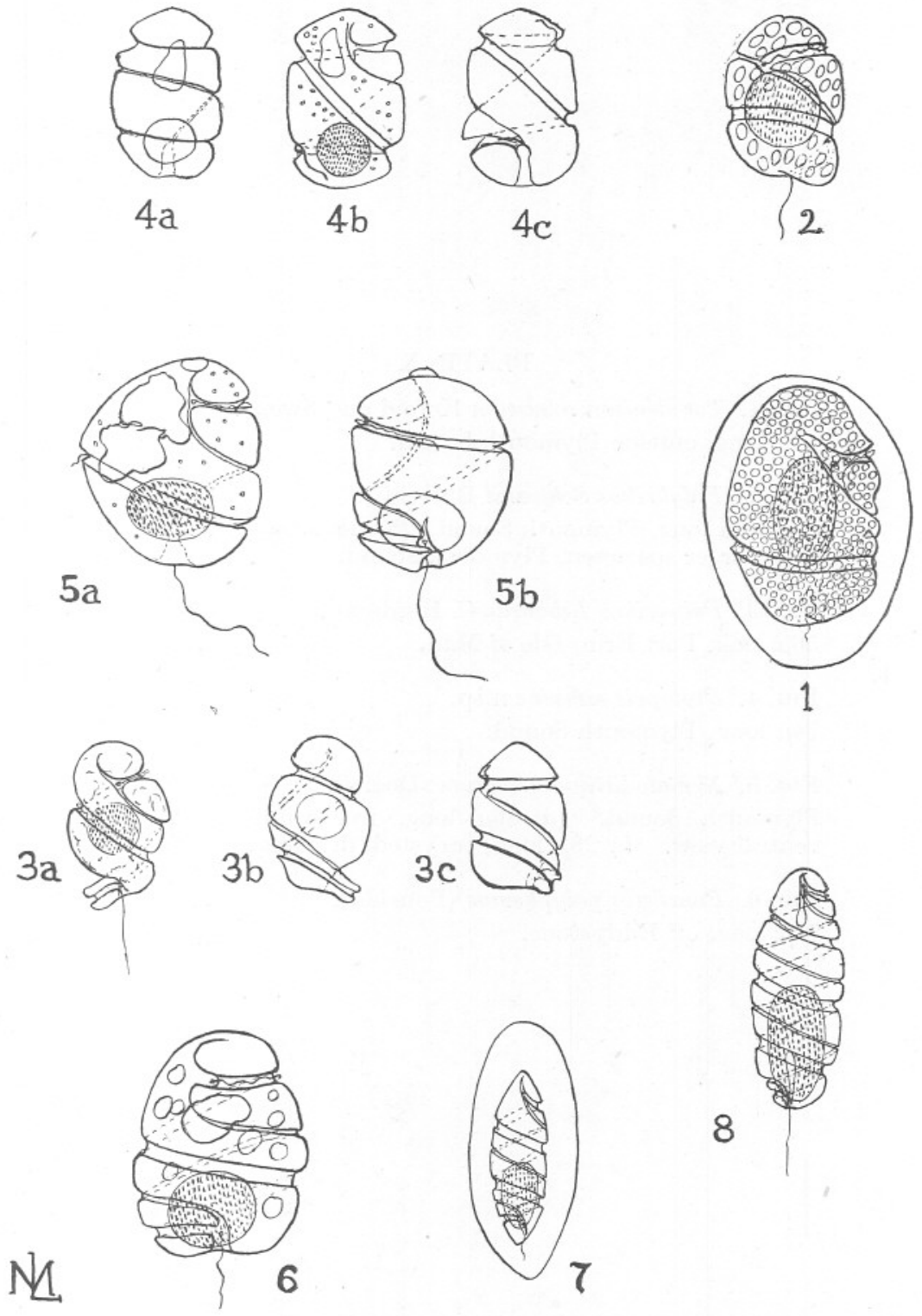


\section{PLATE X}

Fig. 1. Torodinium robustum Kofoid and Swezy.

$57 \mu$ long, outside Plymouth Sound.

FIG. 2. Polykrikos Schwarzi Bütschli.

(a) $100 \mu$ long, Plymouth Sound. (b) nematocyst $19 \mu$ long from larger specimen, Plymouth Sound.

Fig. 3. Polykrikos Lebourae C. Herdman. $56 \mu$ long, Port Erin, Isle of Man.

FIG. 4. Protopsis simplex n.sp.

$74 \mu$ long, Plymouth Sound.

FIG. 5. Nematodinium armatum (Dogiel).

Plymouth Sound. (a) $36 \mu$ long, free-swimming form, ventral view. (b) $28 \mu$ long, encysted, dividing.

Fig. 6. Pouchetia polyphemus (Pouchet).

$75 \mu$ long, off Eddystone. 
[ 193 ]

PLATE X
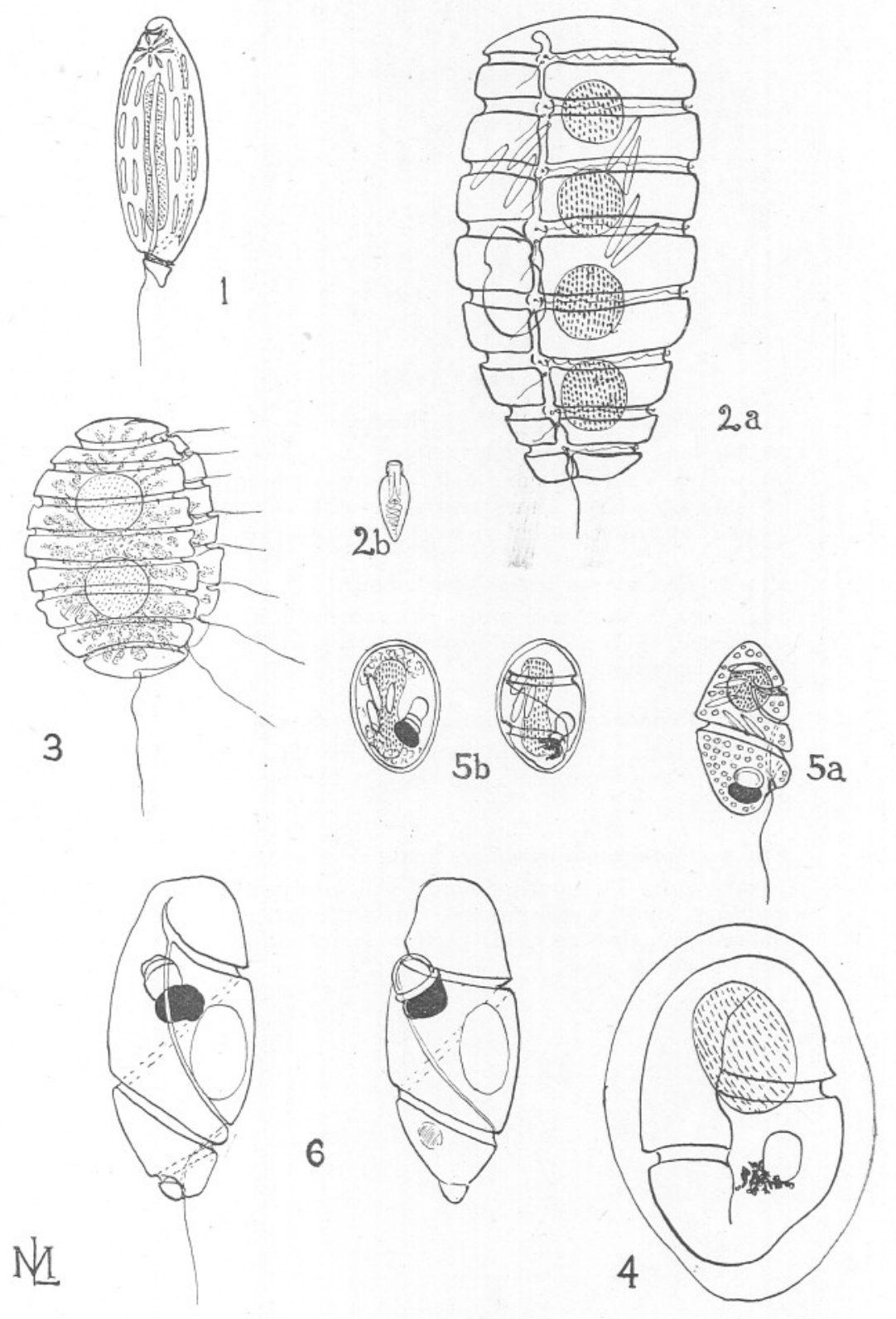


\section{PLATE XI}

FIg. 1. Phalacroma Kofoidi C. Herdman.

$30-33 \mu$ long, Port Erin, Isle of Man. $(a)$ and $(e)$ side views. (b) ventral view. (c) one half, treated with trypan blue. (d) showing theca after treatment with eau de Javelle. $(f)$ and $(g)$ ventro-lateral view, slightly anterior.

FIg. 2. Phalacroma pulchellum Lebour.

$26 \mu$ long, Plymouth Sound. (a) ventral. (b) side view. (c) megacytic form. (d) treated with acid. (e) the two halves separated.

FIG. 3. Phalacroma rotundatum (Clap. and Lach).

(a) $39 \mu$ long, Plymouth Sound. (b) $48 \mu$ long, lately divided, Eddystone, S.W. 3 miles. (c) $45 \mu$ long, Plymouth Sound.

FIG. 4. Phalacroma irregulare n.sp.

55-56 $\mu$ long, Plymouth Sound. All lately divided with megacytic border still present. (a) with part of left longitudinal list missing. (b) perfect longitudinal list. (c) antero-ventral view. 
PLATE XI
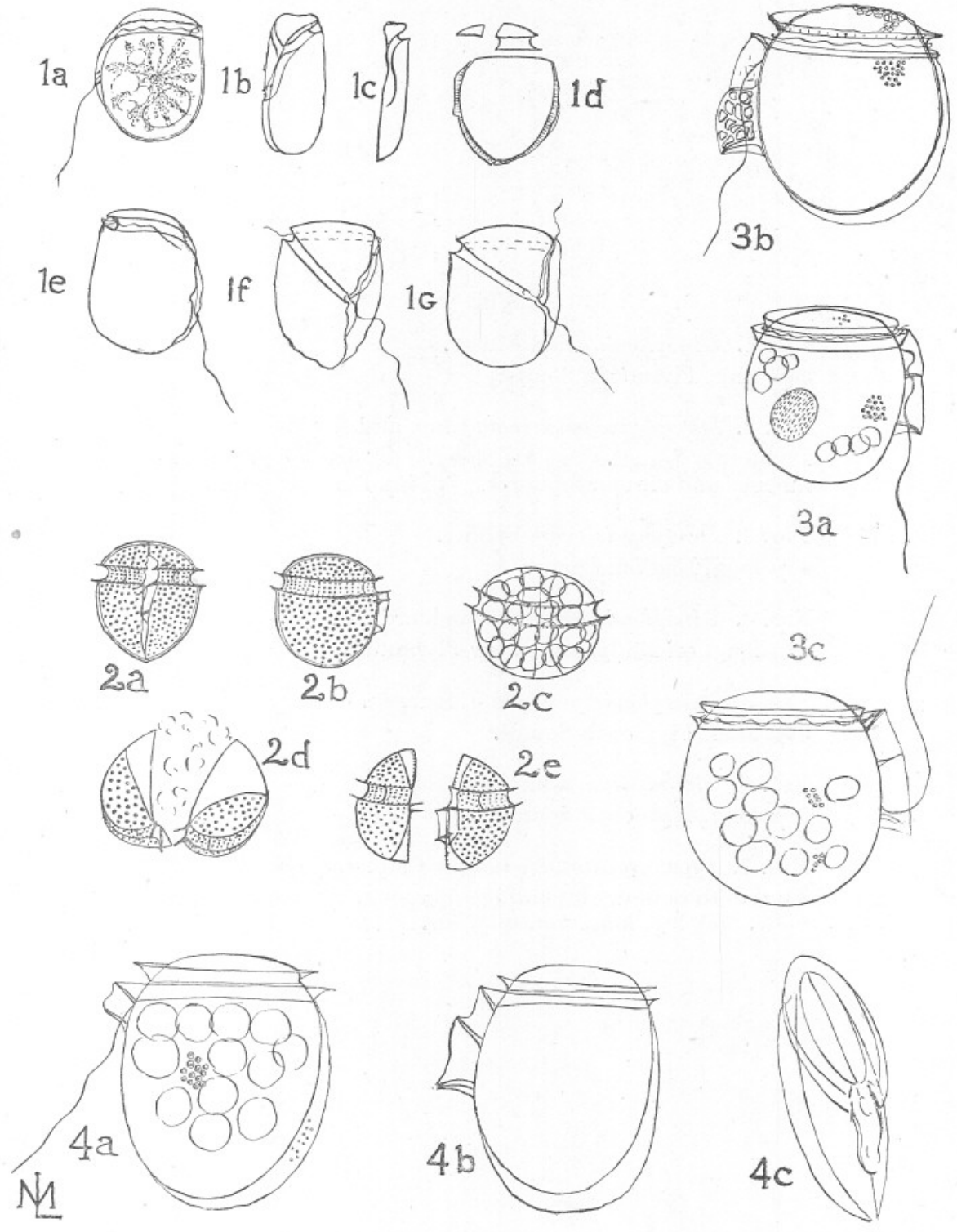


\section{PLATE XII}

FIG. 1. Dinophysis acuta Ehrbg. $54 \mu$ long, Plymouth Sound.

FIG. 2. Dinophysis acuminata Clap. and Lach. Plymouth Sound. (a) $51 \mu$ long. (b) $38 \mu$ long, showing nucleus and chromatophores. (c) $44 \mu$ long, dividing.

FIG. 3. Dinophysis ovum Schütt.

$45 \mu$ long, English Channel.

FIG. 4. Dinophysis lenticula Pavillard.

$43 \mu$ long, off Eddystone, near Plymouth.

FIG. 5. Dinophysis punctata Jörgensen.

$33 \mu$ long, Plymouth Sound.

Fig. 6. Glenodinium danicum Paulsen.

$28 \mu$ long, Plymouth Sound.

FIG. 7. Protoceratium reticulatum Clap. and Lach.

Plymouth Sound. (a) and (b) $56 \mu$ long, ventral and dorsal view. (c) $28 \mu$ long, ventral view. 


\section{[ 197 ]}

PLATE XII
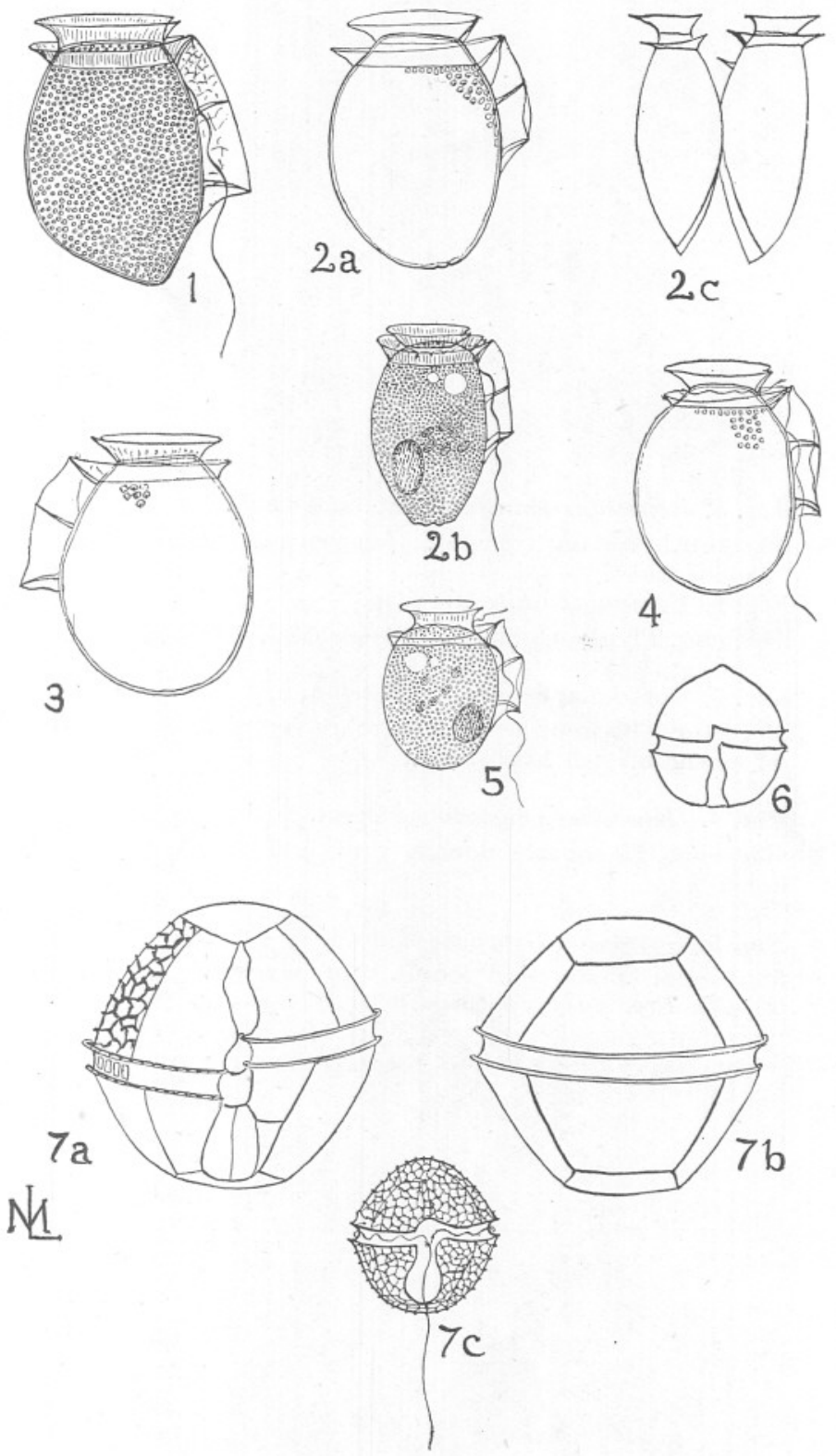


\section{PLATE XIII}

FIG. 1. Goniaulax spinifera Clap. and Lach. $36 \mu$ long, Plymouth Sound. (a) ventral. (b) dorsal.

FIG. 2. Goniaulax unicornis n.sp.

$28 \mu$ long, Plymouth Sound. (a) ventral. (b) dorsal.

FIG. 3. Goniaulax orientalis Lindemann.

$28 \mu$ long, Plymouth Sound. (a) ventral. (b) dorsal. (c) epitheca. (d) hypotheca.

FIG. 4. Goniaulax polygramma Stein.

$45 \mu$ long, Plymouth Sound. (a) and (c) ventral. (b) dorsal.

FIG. 5. Goniaulax Diegensis Kofoid.

$56 \mu$ long, Plymouth Sound. (a) ventral, (b) dorsal. (c) epitheca. (d) hypotheca. 
[ 199 ]

PLATE XIII

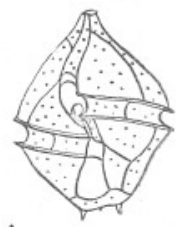

la.

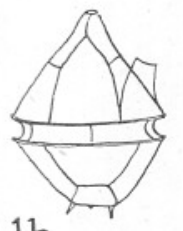

$1 \mathrm{~b}$

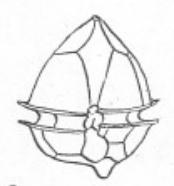

$2 a$

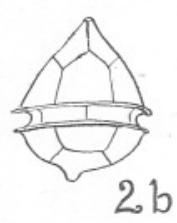

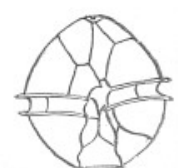

$3 a$

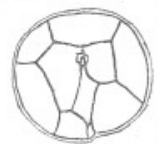

$3 c$

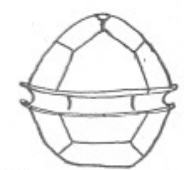

$3 b$

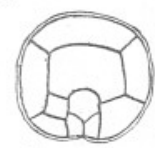

3d
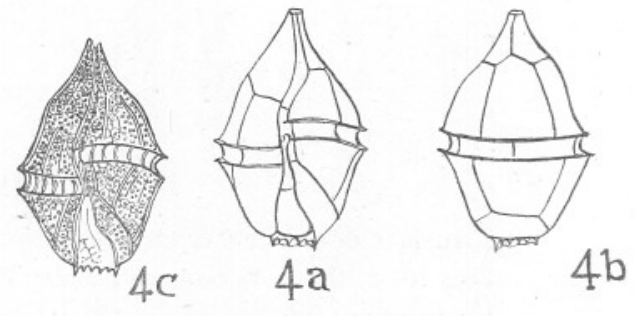

$4 b$

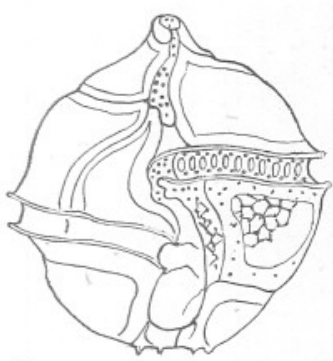

$5 a$

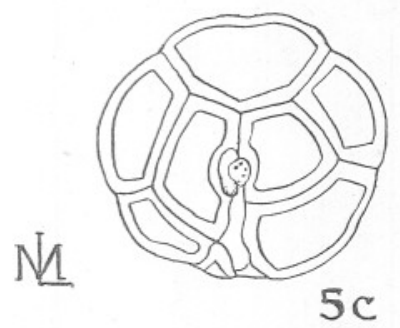

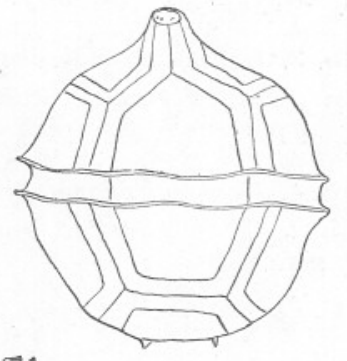

$5 b$

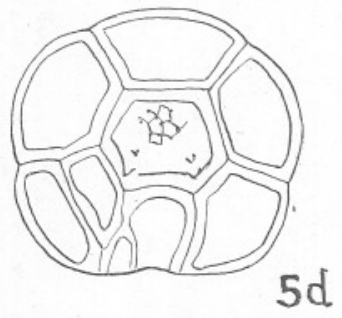




\section{PLATE XIV}

Frg. 1. Goniaulax Tamarensis n.sp.

$36 \mu$ long, Tamar Estuary, near Plymouth. (a) ventral. (b) dorsal. (c) epitheca. (d) hypotheca.

FIg. 2. Goniaulax triacantha Jörgensen.

$42 \mu$ long, Yealm Estuary.

FIG. 3. Goniaulax polyedra Stein.

$42 \mu$ long, Plymouth Sound. (a) ventral. (b) dorsal. (c) hypotheca. (d) epitheca.

FIG. 4. Goniaulax longispina n.sp.

$56 \mu$ long, Plymouth Sound. (a) ventral. (b) dorsal. (c) side. 
[ 201 ]

PLATE XIV

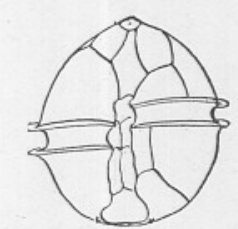

la

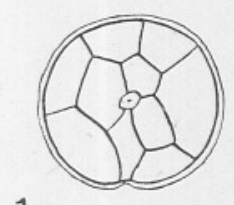

1c

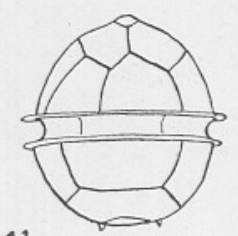

$1 \mathrm{~b}$

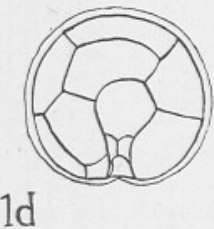

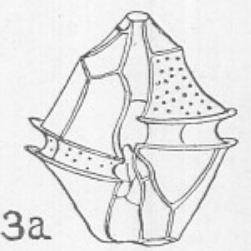
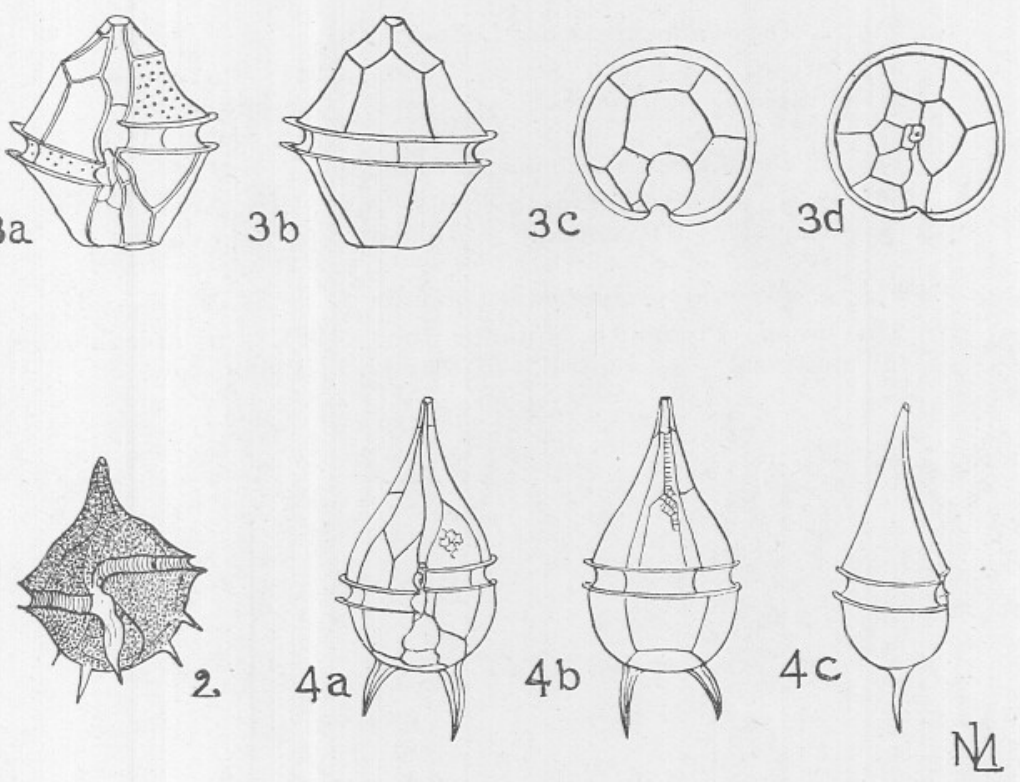


\section{PLATE XV}

Fig. 1. Diplopsalis lenticula Bergh.

$40 \mu$ broad, outside Plymouth Sound. May, 1921. (a) apical view. (b) antapical. (c) ventral. (d) dorsal. (e) side.

Frg. 2. Diplopeltopsis minor Lebour.

$52 \mu$ broad, Plymouth Sound. Feb., 1921. (a) apical. (b) antapical. (c) ventral. (d) dorsal. (e) side view.

Fıg. 3. Peridiniopsis asymmetrica Mangin.

$66 \mu$ broad, outside Plymouth Sound. May, 1921. (a) apical. (b) antapical. (c) ventral. (d) dorsal. (e) side view.

Fig. 4. Peridiniopsis rotunda Lebour.

$28 \mu$ broad, Plymouth Sound. June, 1921. (a) apical. (b) antapical. (c) ventral. (d) dorsal. (e) side view. 
[ 203]

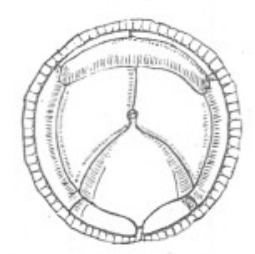

$1 a$
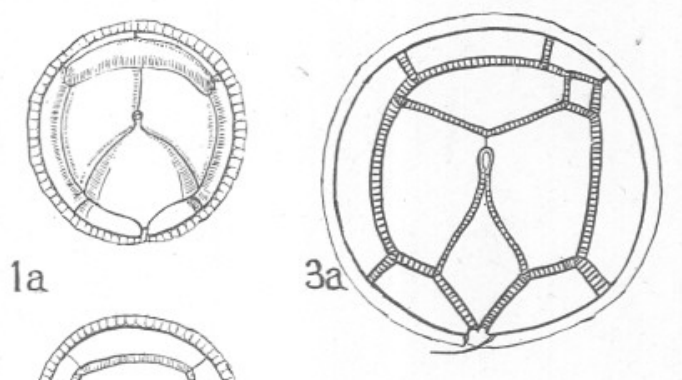

PLATE XV
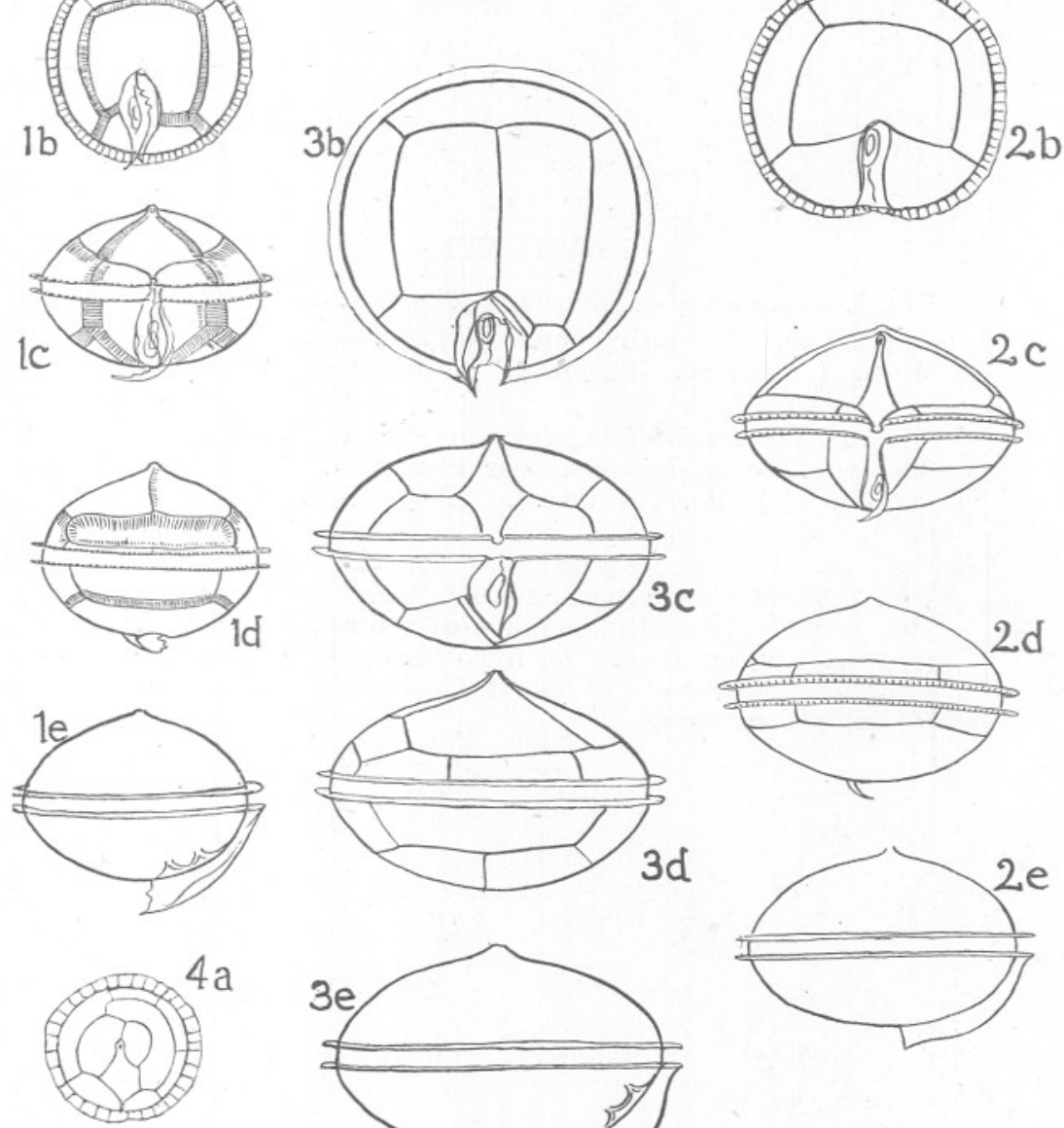

(T) $4 b$
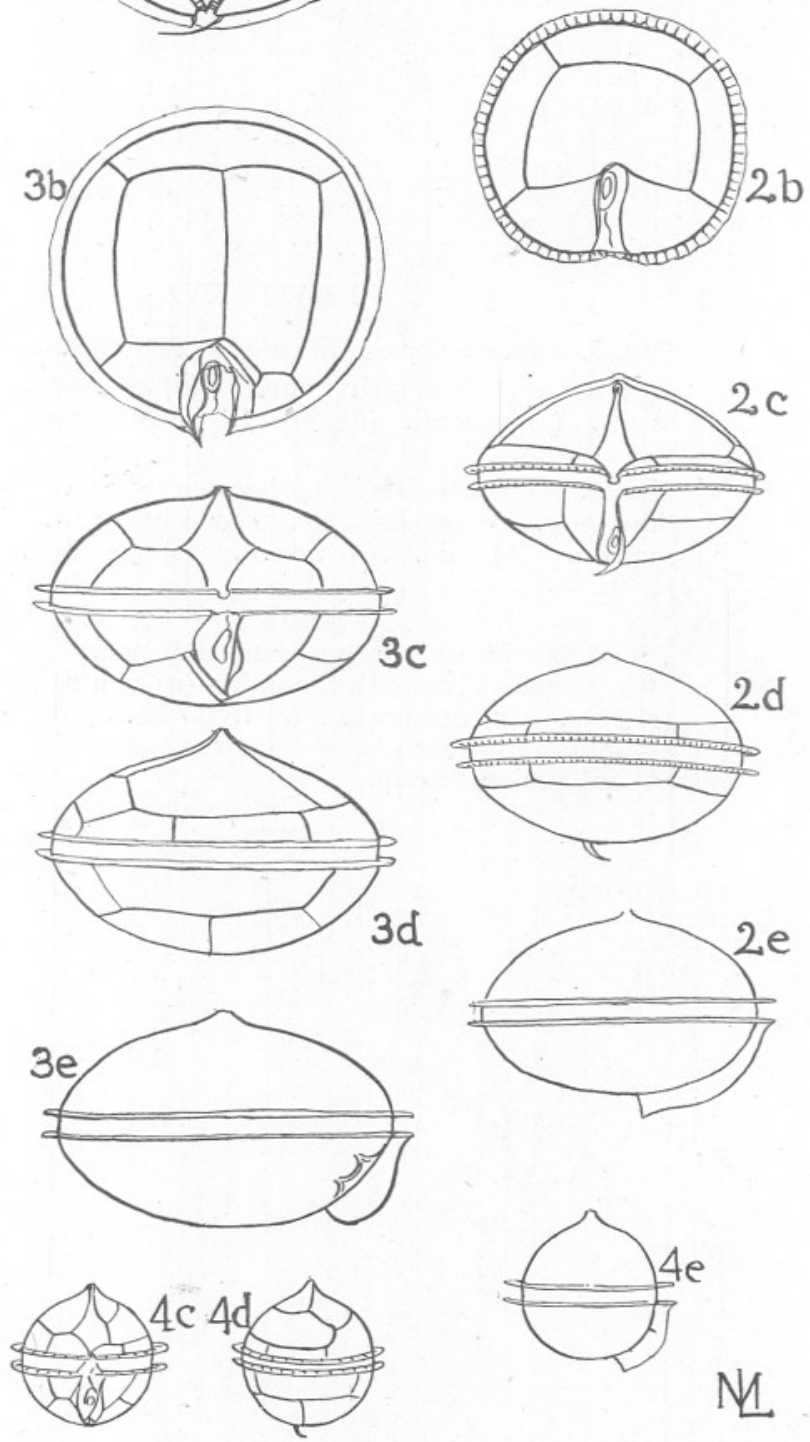


\section{[ 204 ]}

\section{PLATE XVI}

FIG. 1. Diplopsalopsis orbicularis (Paulsen).

$42 \mu$ across, Plymouth Sound. (a) epitheca. (b) hypotheca. (c) ventral. (d) dorsal. (e) abnormal epitheca.

FIG. 2. Kryptoperidinium foliaceum (Stein).

$33 \mu$ long, Yealm Estuary, near Plymouth. $(a)$ and $(c)$ ventral. (b) side. (d) dorsal. (e) epitheca. ( $f$ ) hypotheca.

FIg. 3. Peridinium monospinum Paulsen.

$40 \mu$ across, Plymouth Sound. (a) ventral. (b) dorsal, $(c)$ side. (d) epitheca. (e) hypotheca. (f) with spore escaping. $(g)$ details of longitudinal wing and spines. (h) intercalary striae. 
[205 ]

PLATE XVI.
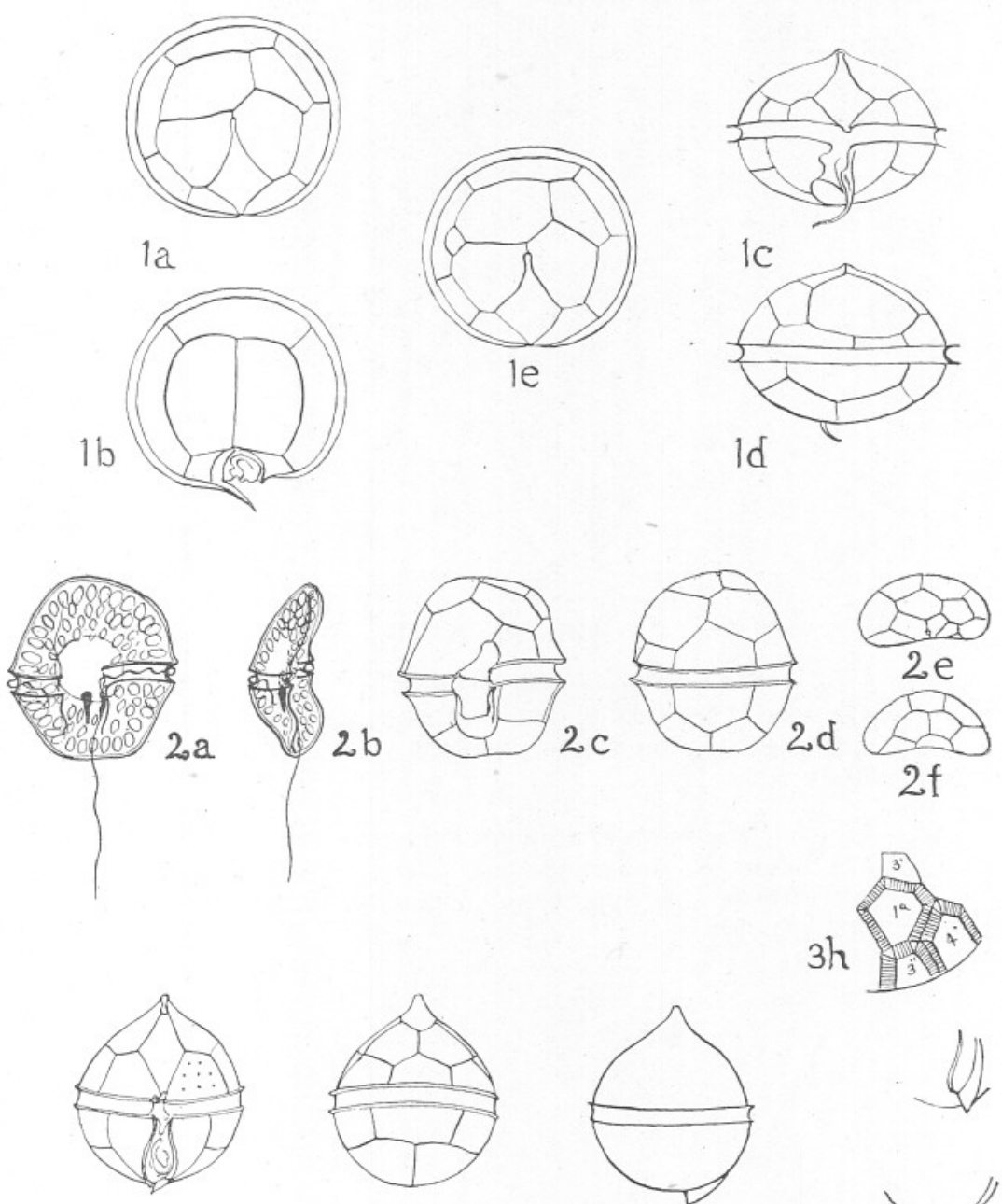

$3 a$

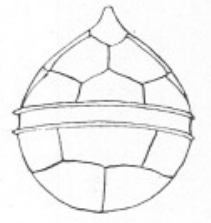

$3 b$

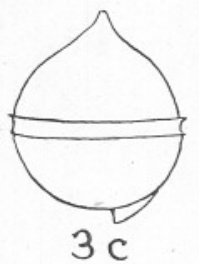

$3 \mathrm{~h}$
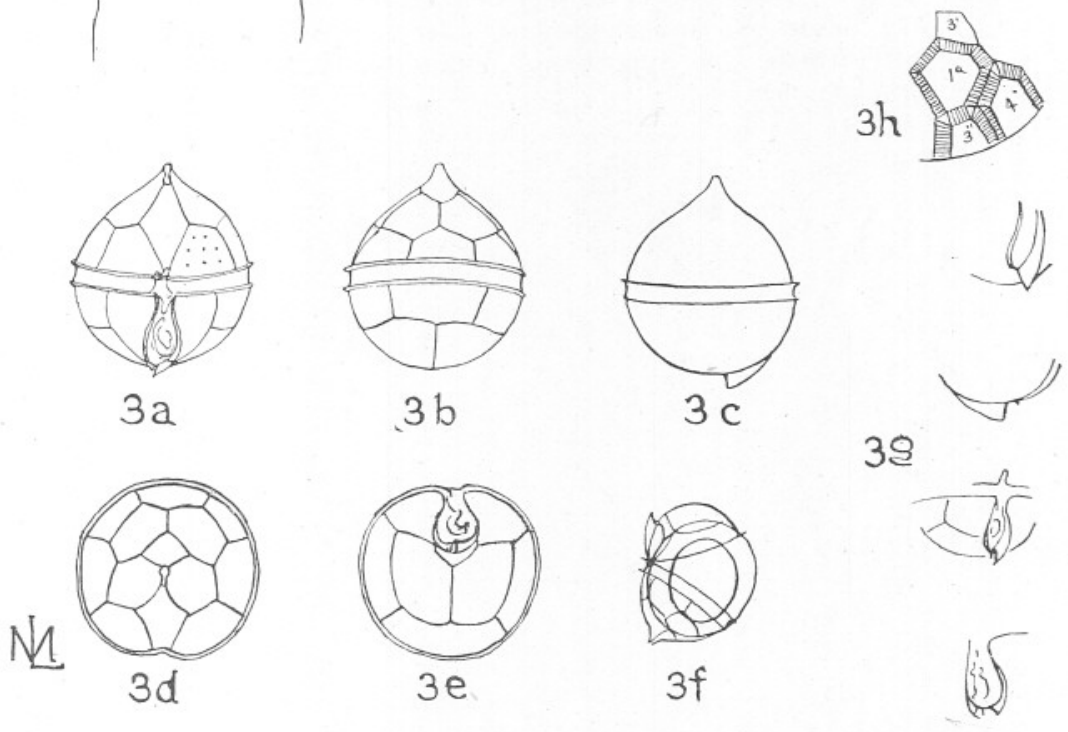


\section{PLATE XVII}

FIG. 1. Peridinium avellana Meunier.

$42 \mu$ long, Plymouth Sound. (a) ventral. (b) dorsal. (c) epitheca. (d) hypotheca. (e) side view. ( $f)$ intercalary striae.

Fıg. 2. Peridinium Thorianum Paulsen.

$57 \mu$ across, Plymouth Sound. (a) ventral. (b) dorsal. $(c)$ epitheca. (d) hypotheca. $(e)$ and $(f)$ various views on smaller scale. 
[ 207 ]

PLATE XVII
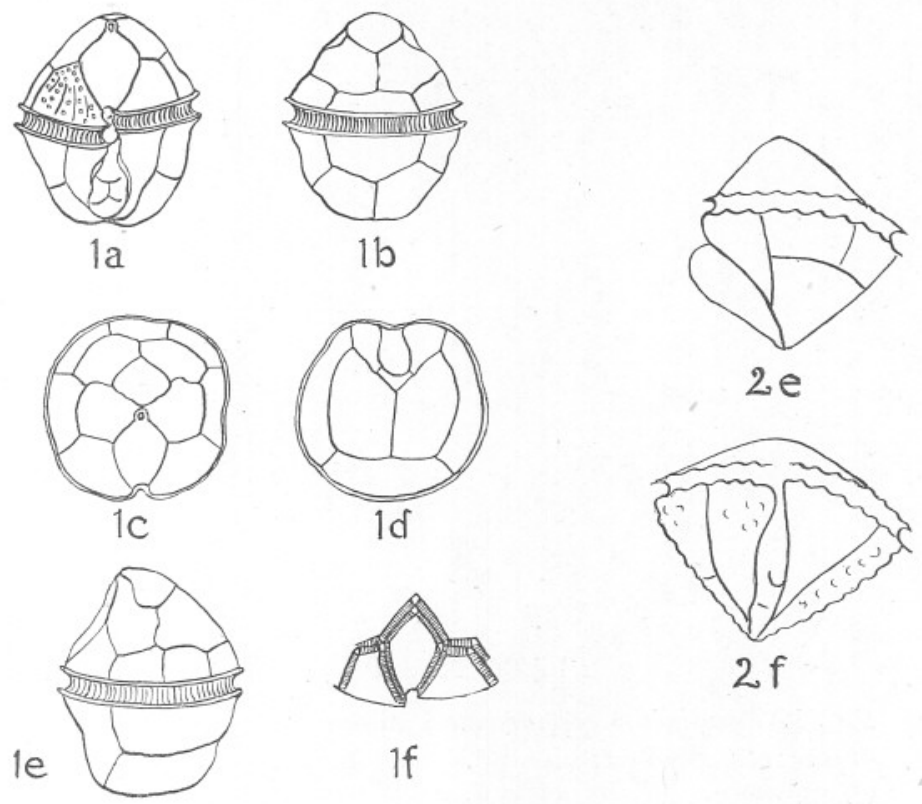

$2 \mathrm{e}$

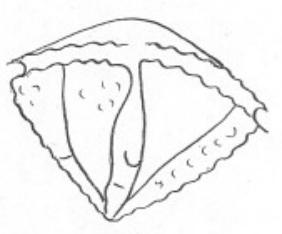

$2 f$
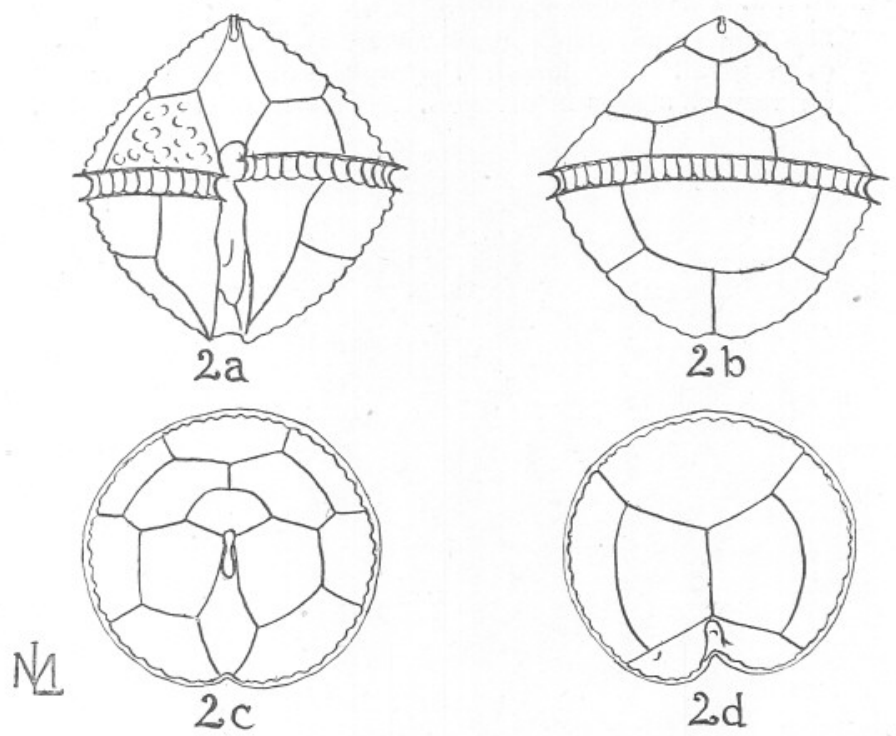
FIG. 1. Peridinium excentricum Paulsen.
$45 \mu$ across, Plymouth Sound.
(c) epitheca. (d) hypotheca.
(a) dorsal.
(b) ventral.

FIG. 2. Peridinium triqueta (Stein).

$28 \mu$ long, from culture in sea water, by Dr. Allen, Plymouth.

(a) ventral. (b) dorsal. (c) epitheca. (d) hypotheca.

$(e)$ various stages in division. ( $f$ ) showing cell contents. 
PLATE XVIII
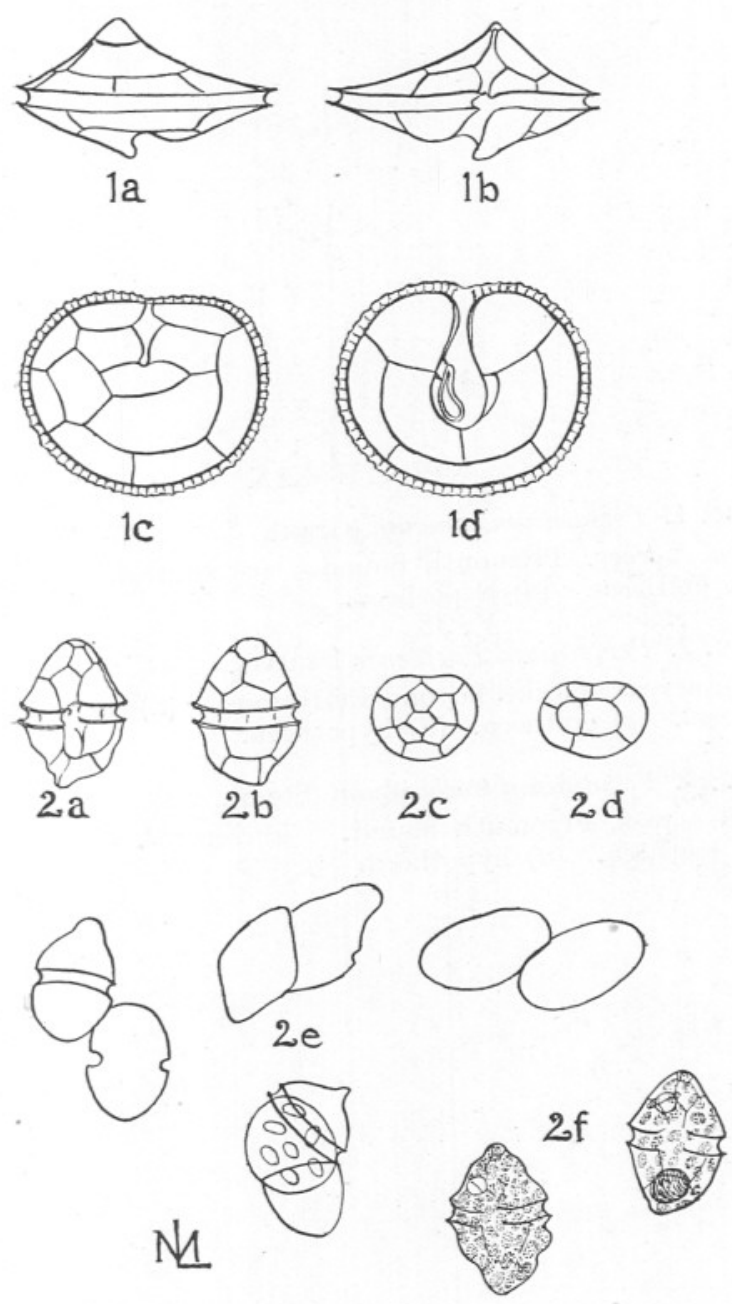


\section{PLATE XIX}

FIG. 1. Peridinium conicum (Gran).

$70 \mu$ across, Plymouth Sound. (a) ventíral. (b) dorsal. (c) epitheca. (d) hypotheca.

FIG. 2. Peridinium Faeröense Paulsen.

$25 \mu$ across, 5 miles beyond Eddystone. (a) ventral. (b) dorsal. (c) epitheca. (d) hypotheca.

FIG. 3. Peridinium trochoideum (Stein).

$28 \mu$ across, Plymouth Sound. (a) ventral. (b) dorsal. (c) epitheca. (d) hypotheca. 


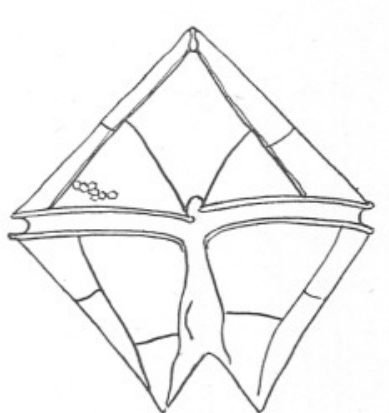

a

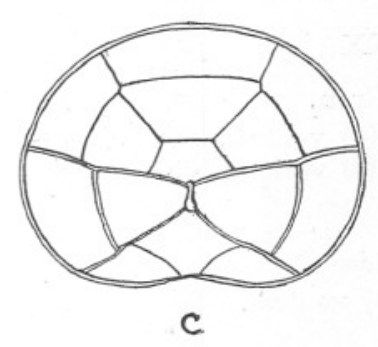

$\frac{A n}{a}$ :

(ख) ती
PLATE XIX

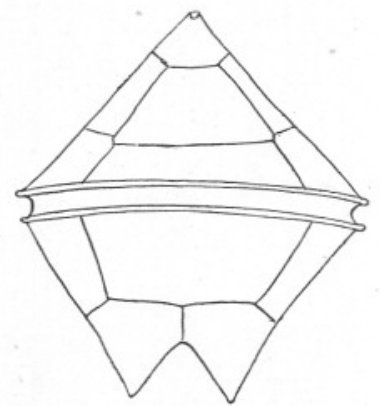

b

1

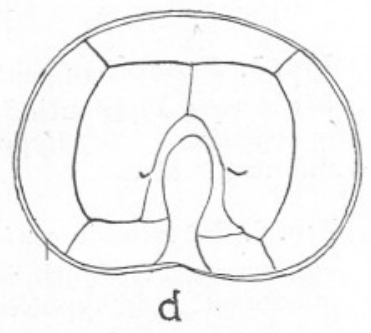

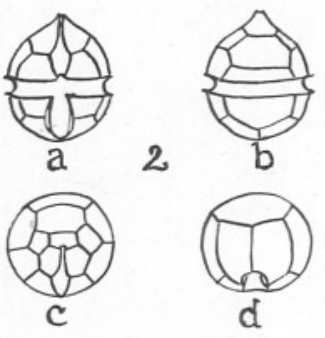




\section{PLATE XX}

FIG. 1. Peridinium pentagonum Gran.

$84 \mu$ across, Plymouth Sound. (a) ventral. (b) dorsal. (c) epitheca. (d) hypotheca. (e) various views on a different scale.

FIG. 2. Peridinium conicoides Paulsen.

$45 \mu$ across, Plymouth Sound. (a) ventral. (b) epitheca. (c) dorsal. (d) hypotheca. 


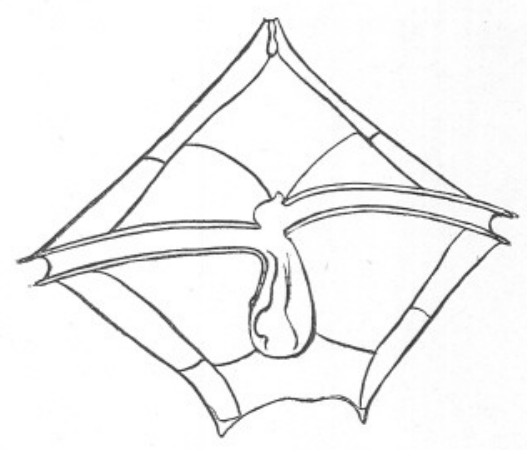

a
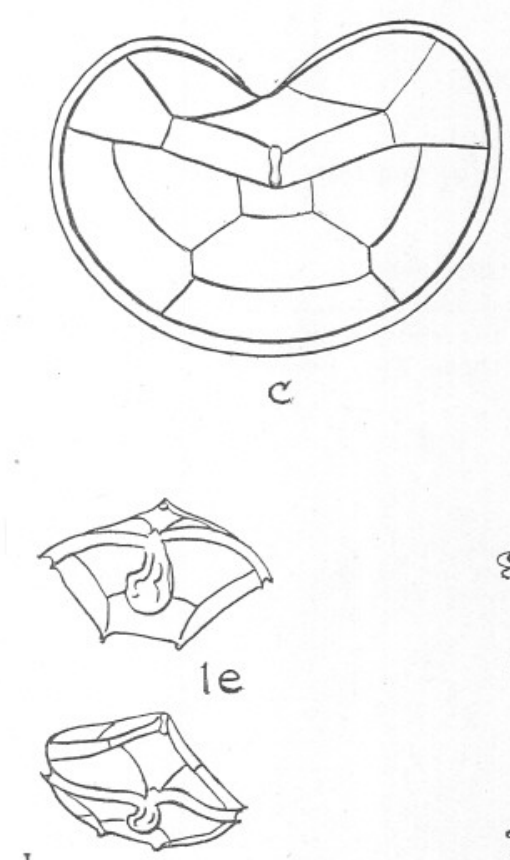

ㄴ.
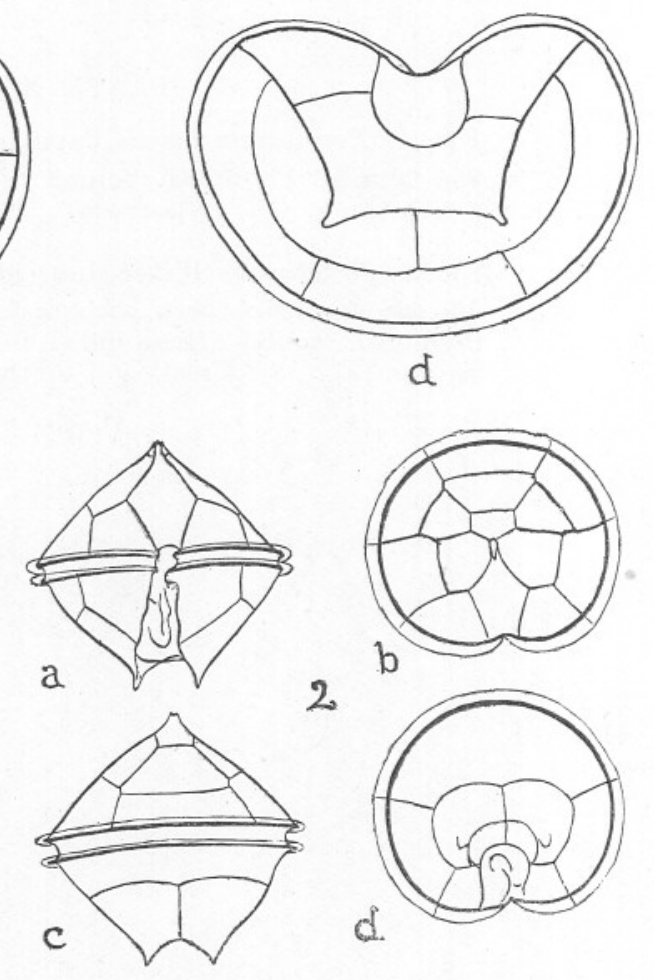

b

PLATE XX

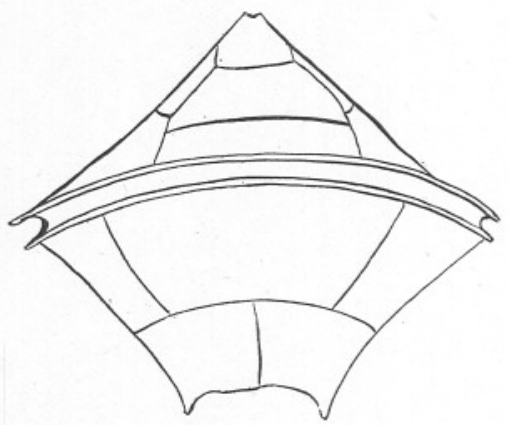

1

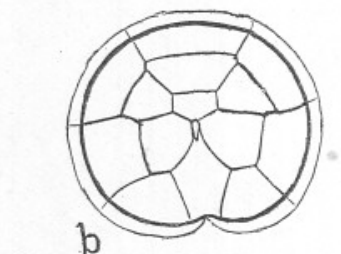

2

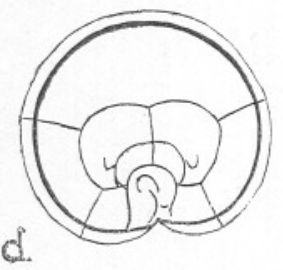


PLATE XXI

Fig. 1. Peridinium Leonis Pavillard.

$95 \mu$ across, Plymouth Sound. (a) ventral. (b) dorsal. (c) epitheca. (d) hypotheca.

FIg. 2. Peridinium Willei Huitfeld-Kaas.

$56 \mu$ across, empty theca, without dorsal plates, from beyond Plymouth Sound (these filled in from Schilling, 1913). (a) ventral. (b) dorsal. (c) epitheca. (d) hypotheca. 
[ 215 ]

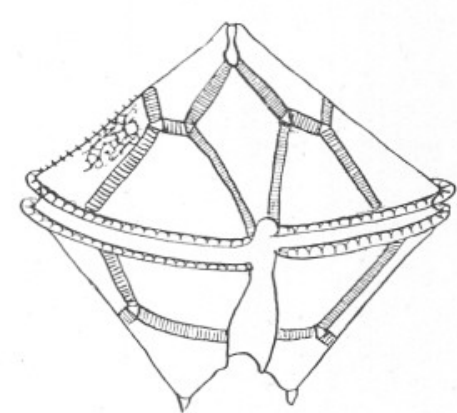

a

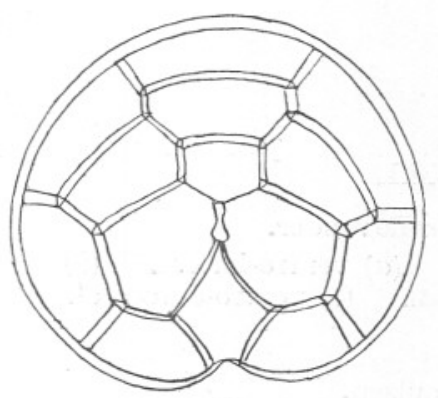

c

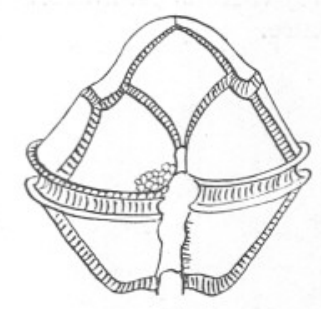

a

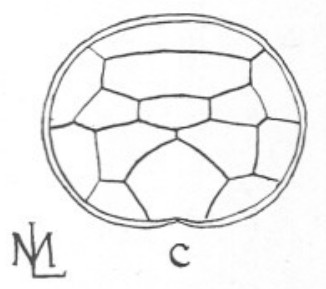

PLATE XXI

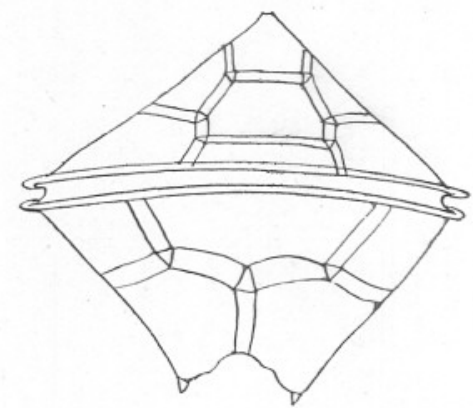

b

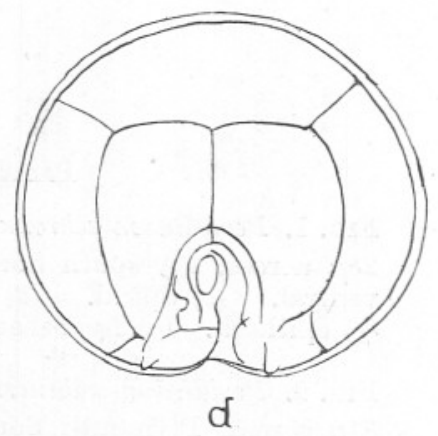

2
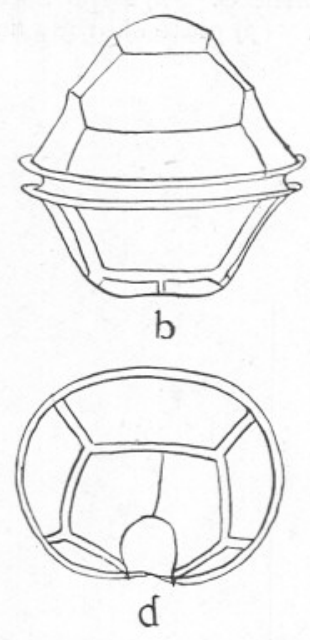


\section{PLATE XXII}

Fig. 1. Peridinium achromaticum Levander.

$28 \mu$ across, Plymouth Sound. (a) ventro-lateral. (b) ventral. (c) apical. (d) dorsal. (e) ventro-antapical. $(f)$ epitheca. ( $g$ ) hypotheca.

FIG. 2. Peridinium subinerme Paulsen.

$54 \mu$ across, Plymouth Sound. (a) ventral. (b) dorsal. (c) epitheca. (d) hypotheca. (e) various views on smaller scale. $(f)$ plate showing sculpture. 
[ 217 ]
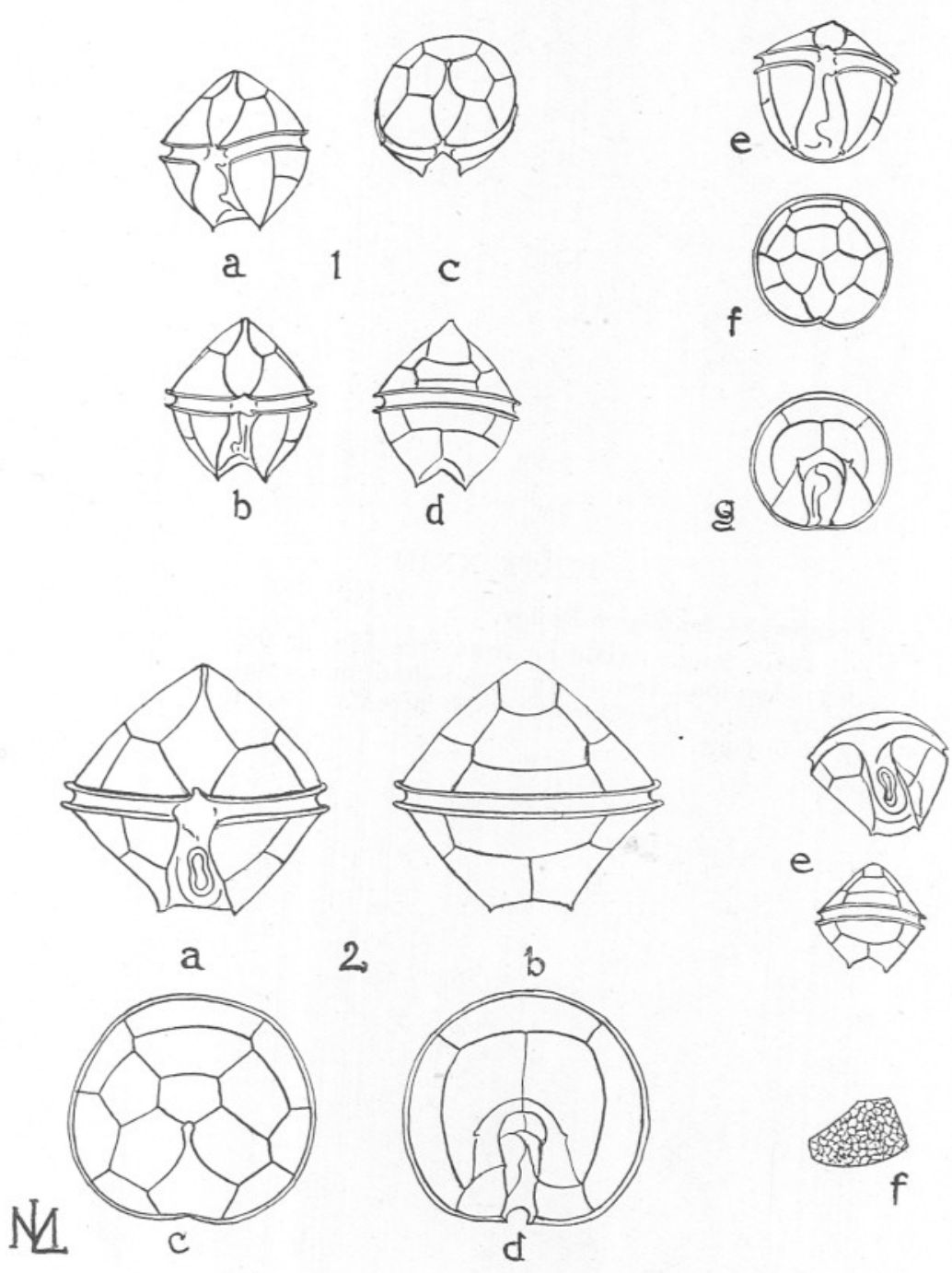


\section{PLATE XXIII}

Peridinium depressum Bailey.

(a) $180 \mu$ long, Atlantic, from the Scotia Expedition. (b-f) $116 \mu$ long, from Plymouth Sound (on a smaller scale).
(b) ventral.
(c) dorsal,
(d) apical.
(e) antapical.

\section{$(f)$ side view.}


PLATE XXIII
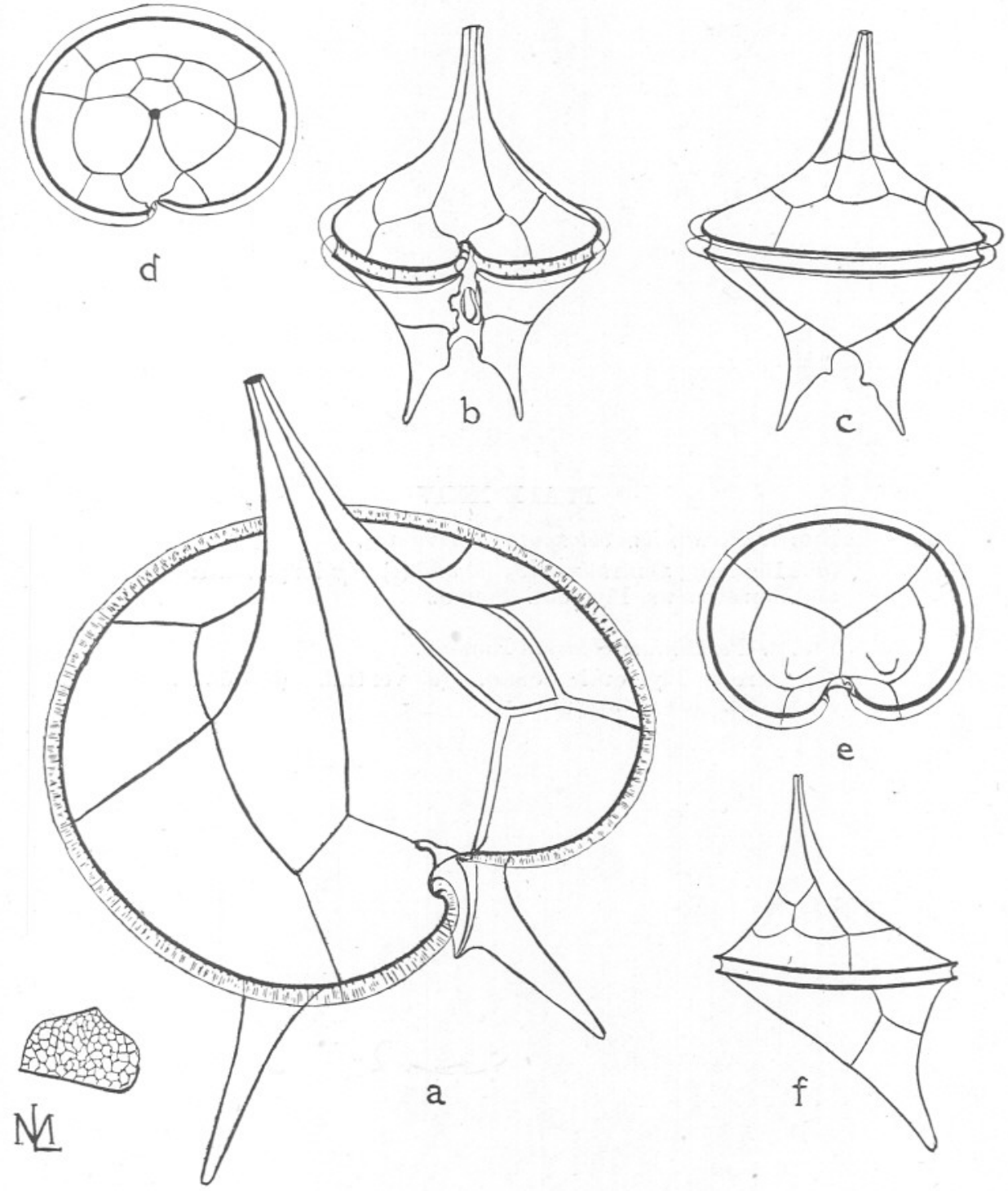

e

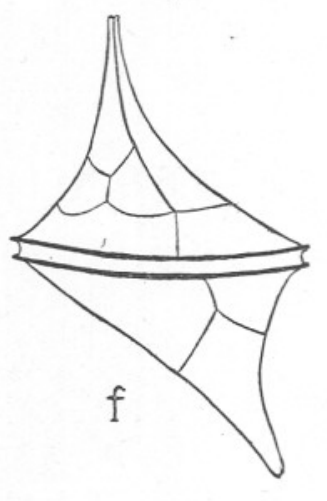


FIG. 1. Peridinium oblongum (Aurivillius).

(a) $115 \mu$ long, ventral view. (b) and (c) $84 \mu$ long, ventral and dorsal views, Plymouth Sound.

FIG. 2. Peridinium obtusum Karsten.

$50 \mu$ across, Plymouth Sound. (a) ventral. (b) dorsal. (c) apical. (d) antapical view. 


\section{[ 221 ]}

PLATE XXIV
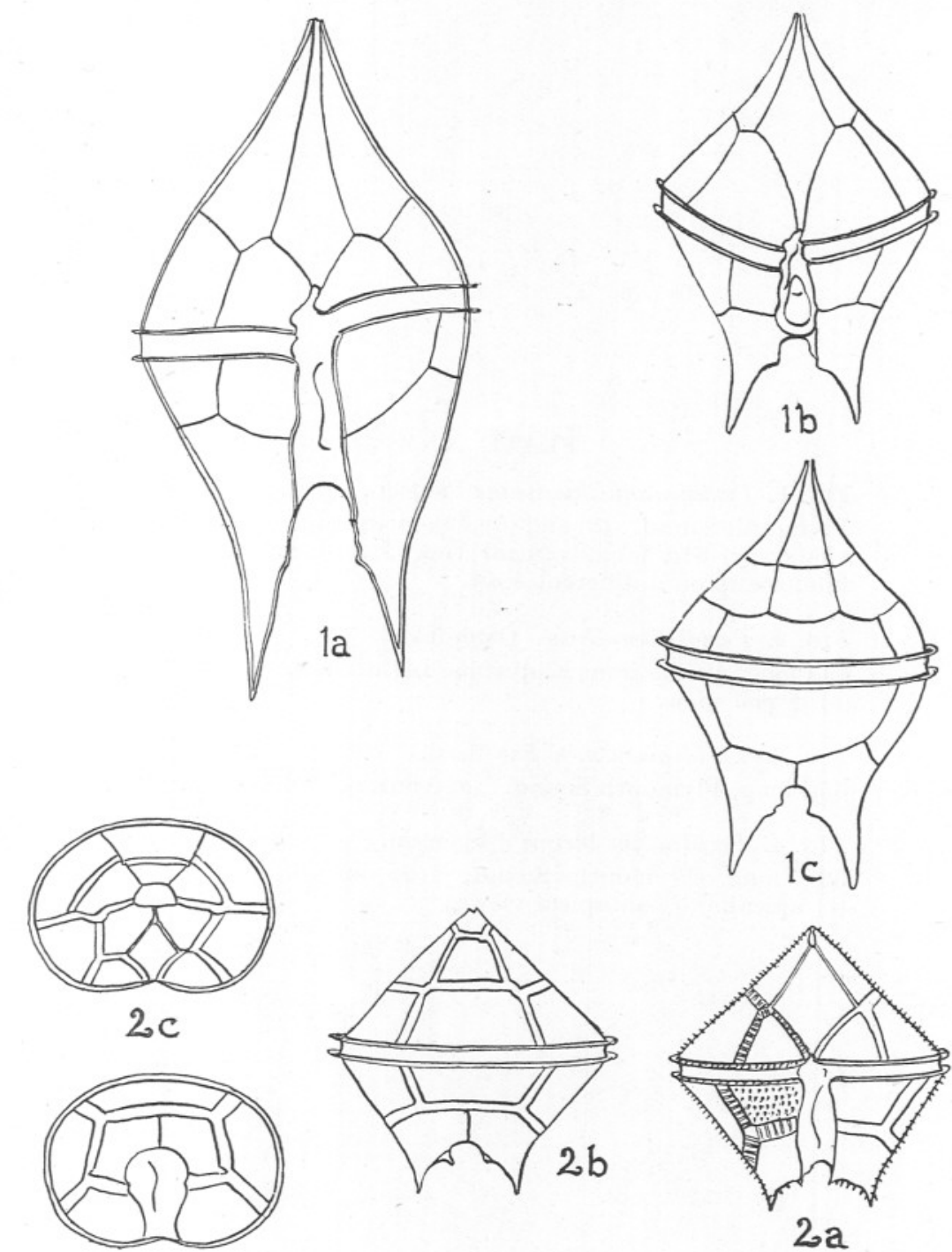

$M \quad 2 d$
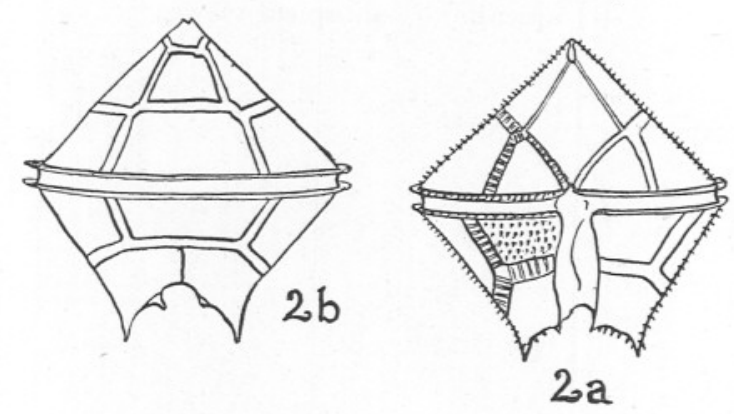


\section{PLATE XXV}

FIg. 1. Peridinium Claudicans Paulsen.

Plymouth Sound. (a) and (b) $79 \mu$ long, ventral and dorsal views. (c) $51 \mu$ long, ventral view. (d) dorsal, side and hind views on a different scale.

FIG. 2. Peridinium Granii Ostenfeld.

$49 \mu$ long, $\frac{1}{2}$ mile from Eddystone Lighthouse. $(a)$ ventral. (b) dorsal view.

FIG. 3. Peridinium mite Pavillard.

$55 \mu$ long, Plymouth Sound. (a) ventral. (b) dorsal view.

FIG. 4. Peridinium Steinii Jörgensen.

$39 \mu$ long, Plymouth Sound. (a) ventral. (b) dorsal. (c) apical. (d) antapical views. 

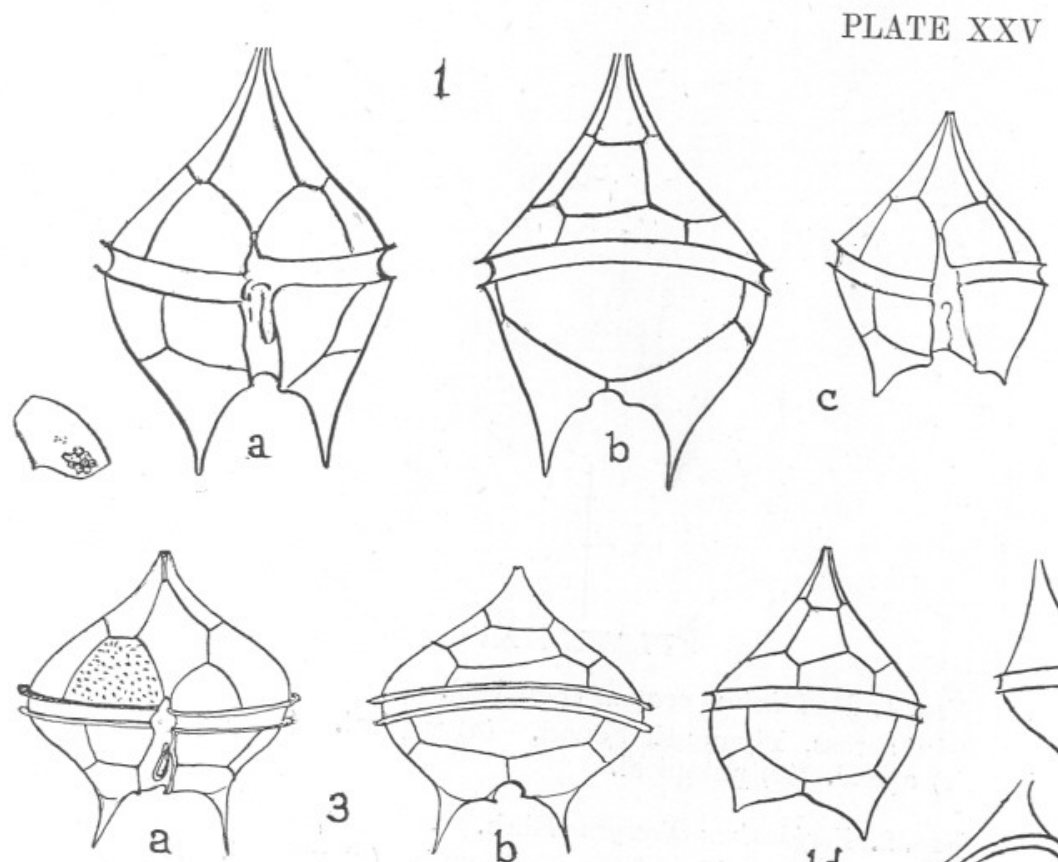

3
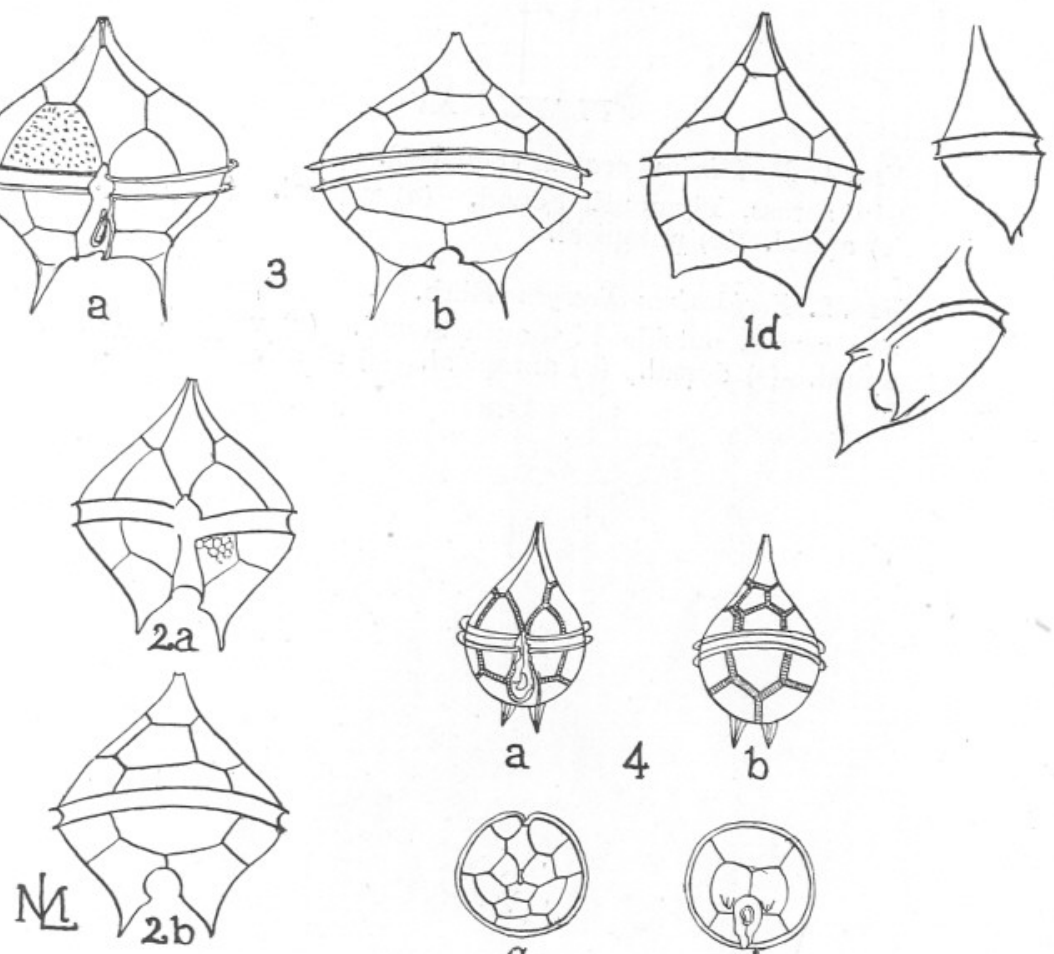

a

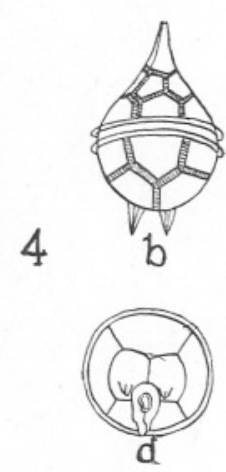


[ 224 ]

\section{PLATE XXVI}

FIg. 1. Peridinium ovatum (Pouchet).

$64 \mu$ across, Plymouth Sound. (a) ventral. (b) dorsal. (c) apical. (d) antapical.

FIG. 2. Peridinium divergens Ehrb.

$56 \mu$ across, outside Plymouth Sound. (a) ventral. (b) apical. (c) dorsal. (d) antapical. (e) showing live cell. 

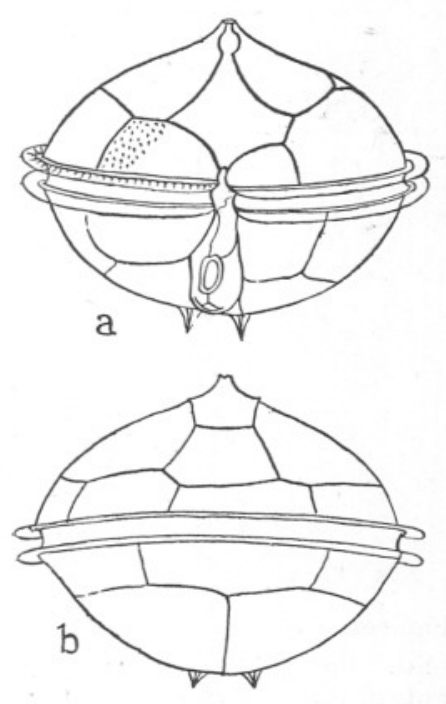

1

PLATE XXVI
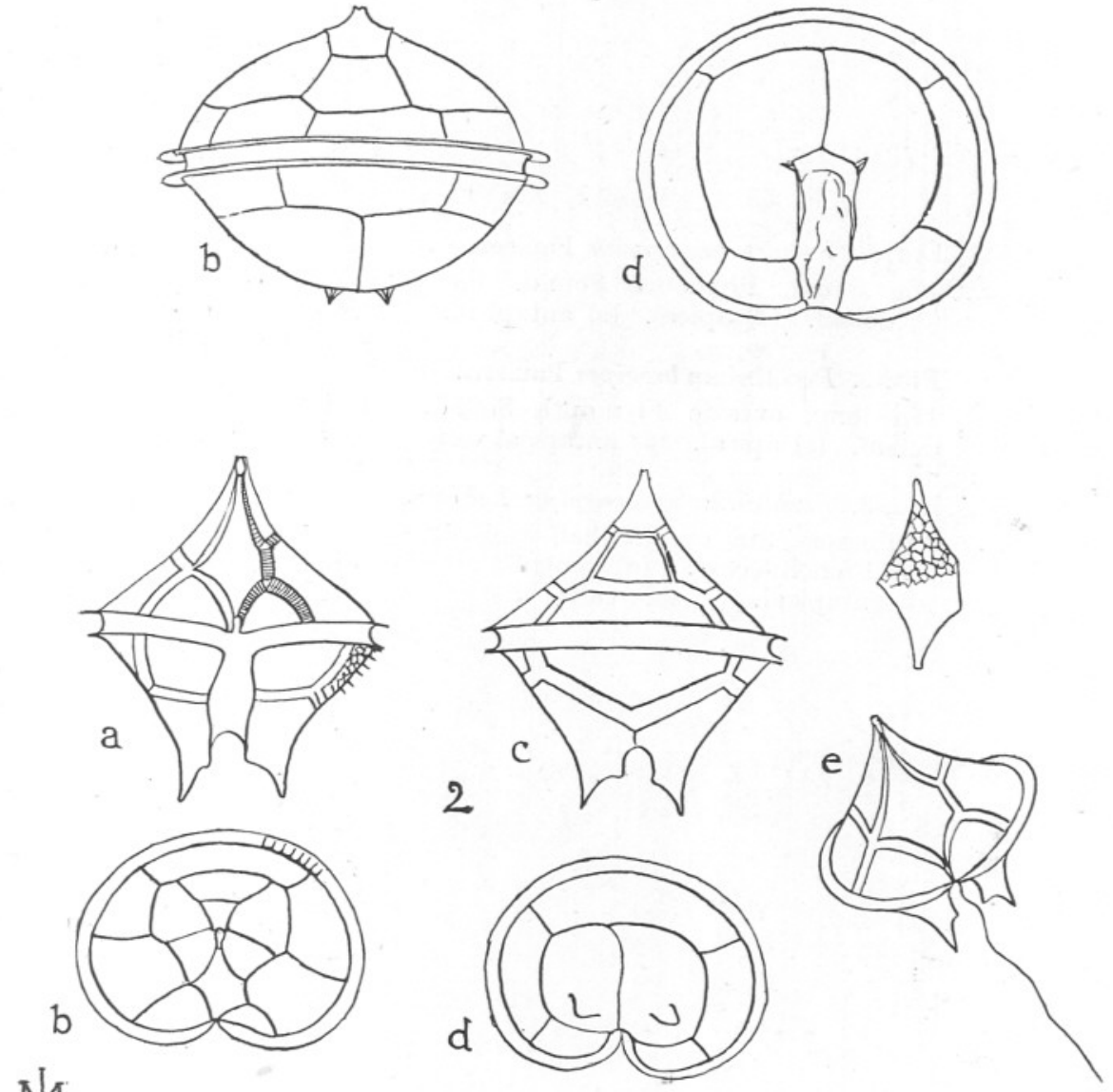


\section{PLATE XXVII}

FIG. 1. Peridinium cerasus Paulsen. $30 \mu$ across, Plymouth Sound. (a) alive. (b) ventral. (c) dorsal. (d) apical. (e) antapical.

FIg. 2. Peridinium brevipes Paulsen.

$18 \mu$ long, outside Plymouth Sound. (a) ventral. (b) dorsal. (c) apical. (d) antapical view.

FIG. 3. Peridinium sub-curvipes Lebour.

$44 \mu$ across, Station E.2, half-way between Plymouth and the French coast. (a) ventral. (b) dorsal. (c) apical. (d) antapical. (e) side view. 


\section{[ 227 ]}

PLATE XXVII
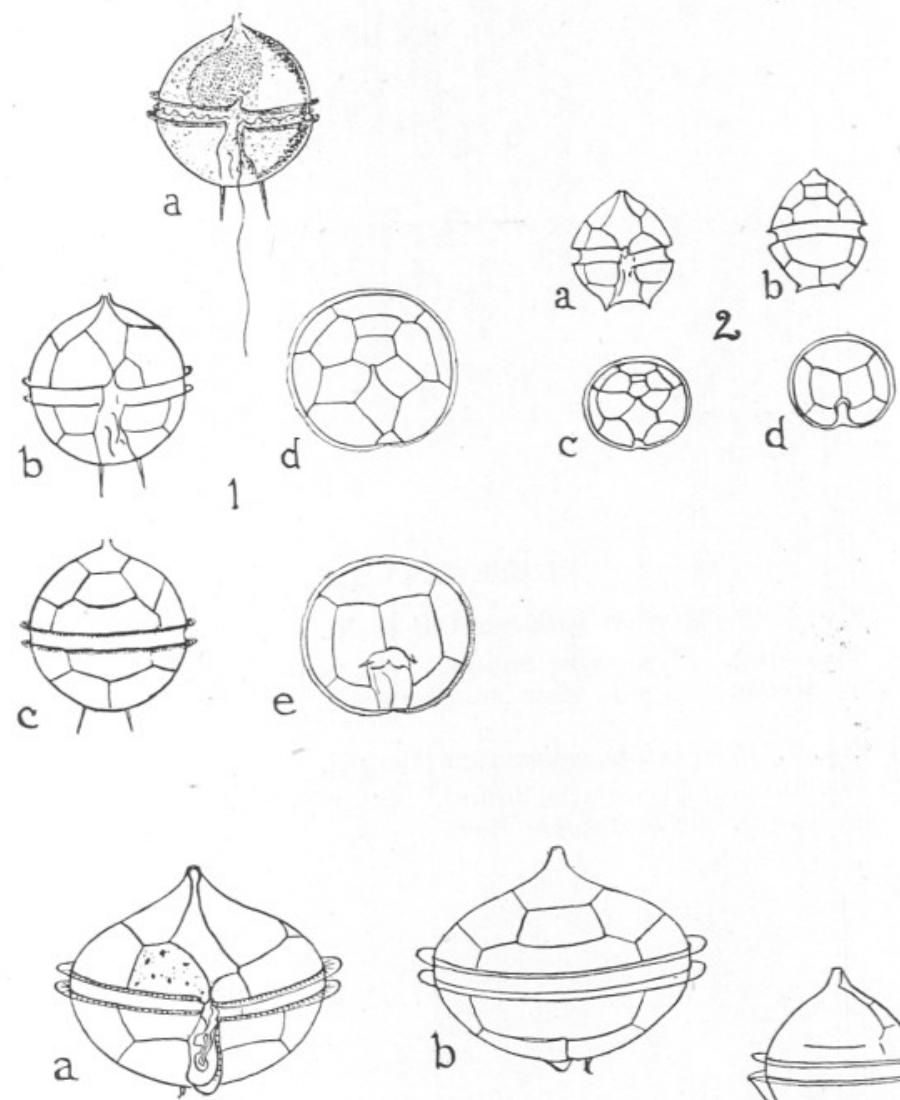

3

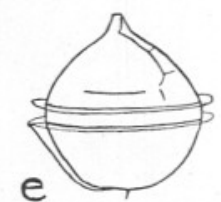

C
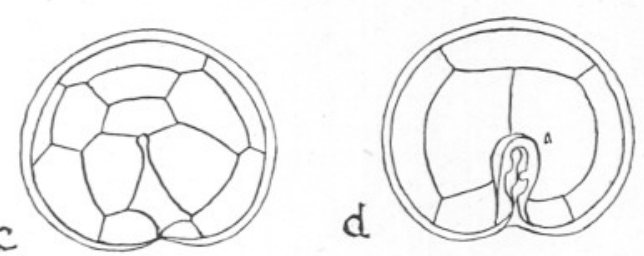

丰 
PLATE XXVIII

FIG. 1. Peridinium pallidum Ostenfeld.

$96 \mu$ long, Plymouth Sound. (a) ventral. (b) dorsal. (c) apical. (d) side view (smaller scale).

FIG. 2. Peridinium pellucidum (Bergh).

$36 \mu$ broad, Plymouth Sound. (a) ventral.» (b) dorsal. (c) apical. (d) antapical view. 
[ 229]
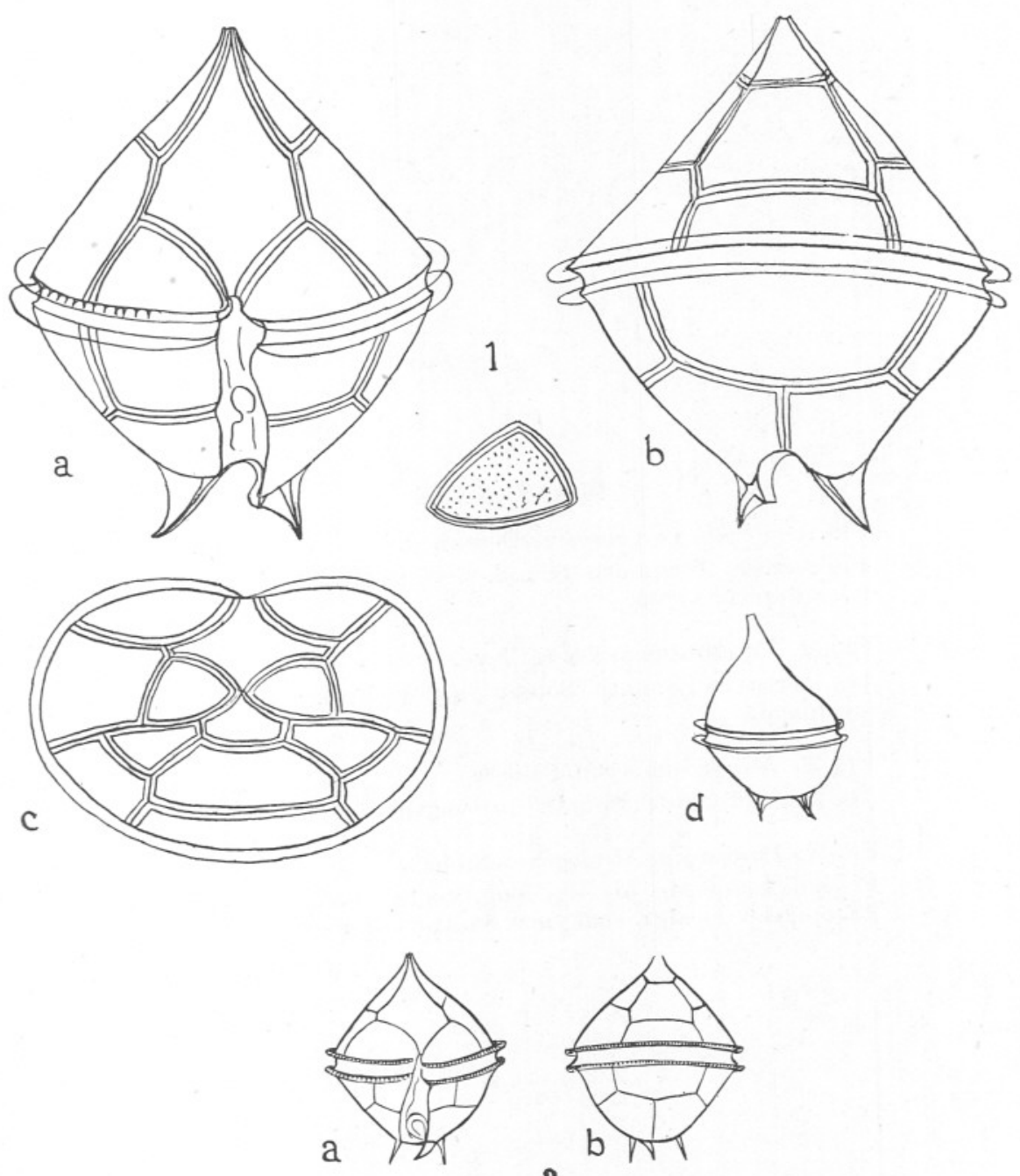

2
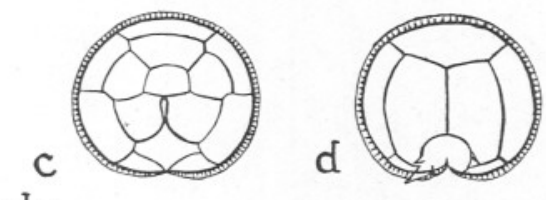

N 


\section{PLATE XXIX}

FIG. 1. Peridinium curvipes Ostenfeld.

$45 \mu$ across, Plymouth Sound. (a) ventral. (b) apical. (c) antapical views.

FIg. 2. Peridinium diabolus Cleve.

$44 \mu$ across, Plymouth Sound. (a) ventral. (b) dorsal. (c) apical.

FIG. 3. Minuscula bipes (Paulsen).

$23 \mu$ long, Plymouth Sound. (a) ventral. (b) dorsal view.

FIG. 4. Pyrophacus horologicum Stein.

Plymouth Sound. (a) $40 \mu$ long, ventral view, with eyst. (b) apical. (c) antapical view, $84 \mu$ by $74 \mu$ diameter. 
[ 231 ]

PLATE XXIX
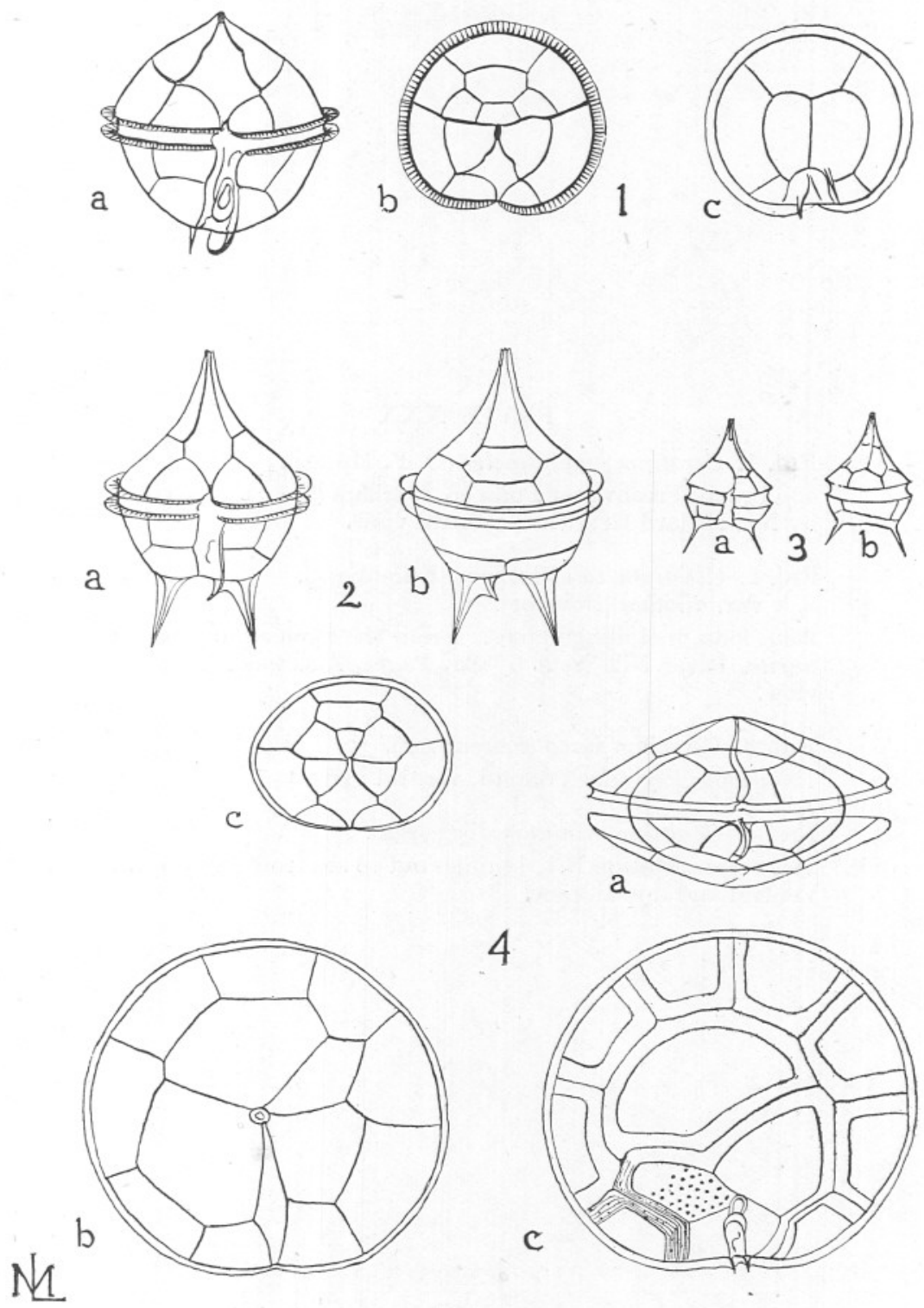


\section{PLATE XXX}

Fıg. 1. Ceratium hirundinella (O. F. Müller).

$42 \mu$ broad, Freshwater Pond co. Durham (from sample sent by Mr. Millard Griffiths), ventral view.

FIG. 2. Ceratium candelabrum (Ehrenberg), var. dilatata (Gourret).

$260 \mu$ long, including spines. From the stomach of Clupea aurita, River Nile (sent by Mr. Paget, Alexandria), dorsa] view.

FIG. 3. Ceratium furca (Ehrenberg).

$150 \mu$ long, Plymouth Sound, ventral view.

FIg. 4. Ceratium minutum Jörgensen.

$28 \mu$ across, Station E.1, 14 miles out to sea from Plymouth. Ventral and dorsal view, 
[ 233 ]

PLATE XXX
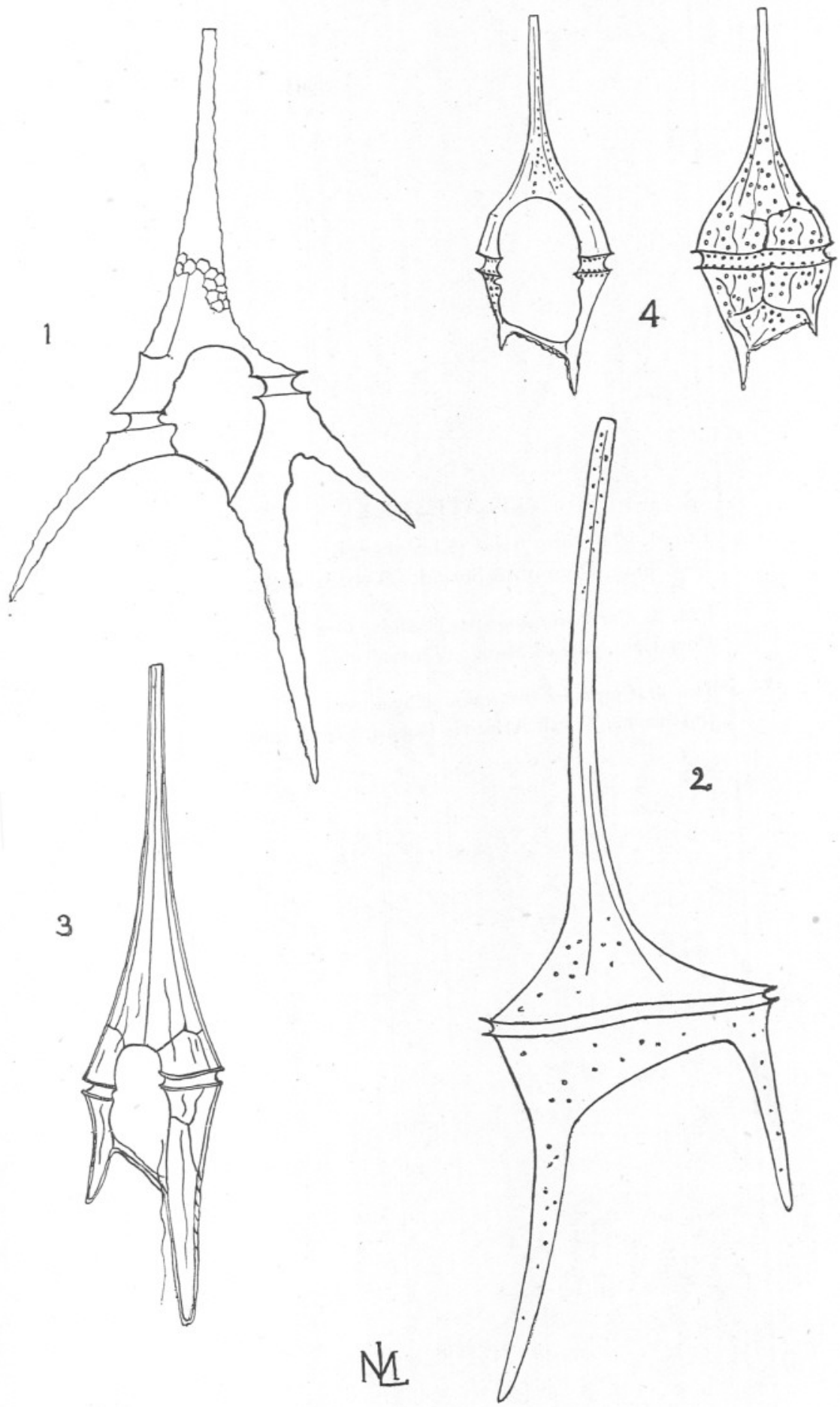
[ 234 ]

\section{PLATE XXXI}

FIG, 1. Ceratium fusus (Ehrenberg). $480 \mu$ long, Plymouth Sound. Ventral view.

FIg. 2. Ceratium longipes (Bailey) Gran.

Port Erin, Isle of Man. Ventral view.

FIG. 3. Ceratium arcticum (Ehrenberg).

$48 \mu$ broad, North Atlantic Ocean, Scotia material. 
[ 235 ]

PLATE XXXI
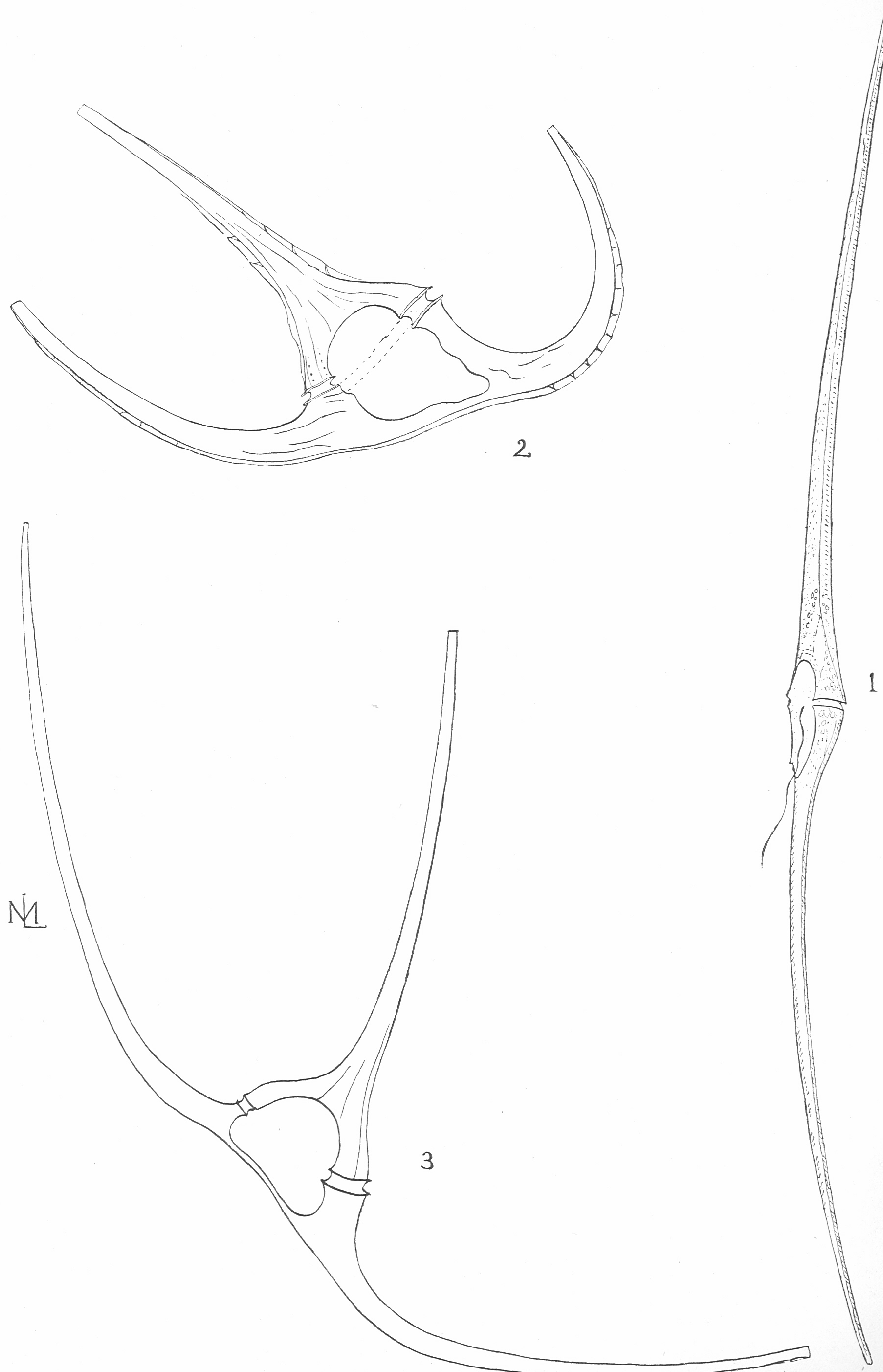
[ 236 ]

\section{PLATE XXXII}

Ceratium tripos (O. F. Müller). var. Baltica Schütt.

$60 \mu$ broad, $210 \mu$ long, Plymouth Sound. (a) ventral view. $(b)$ and $(c)$ showing plates (lesser magnification). 
[ 237 ]

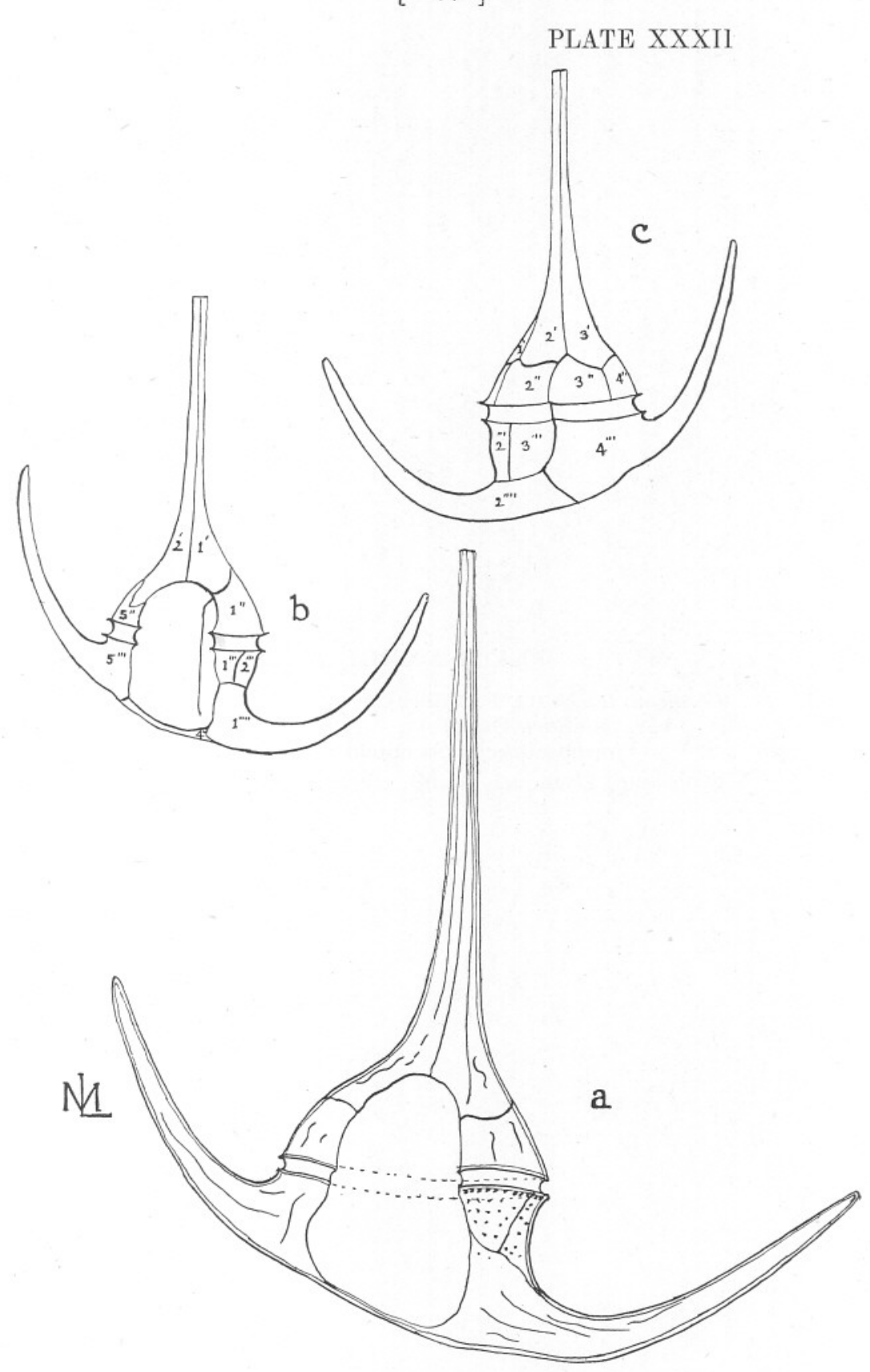


[ 238 ]

PLATE XXXIII

Ceratium tripos (O. F. Müller).

var. Atlantica Ostenfeld. forma neglecta (Ostenfeld)

$270 \mu$ long, Plymouth Sound. Ventral view. 
PLATE XXXIII

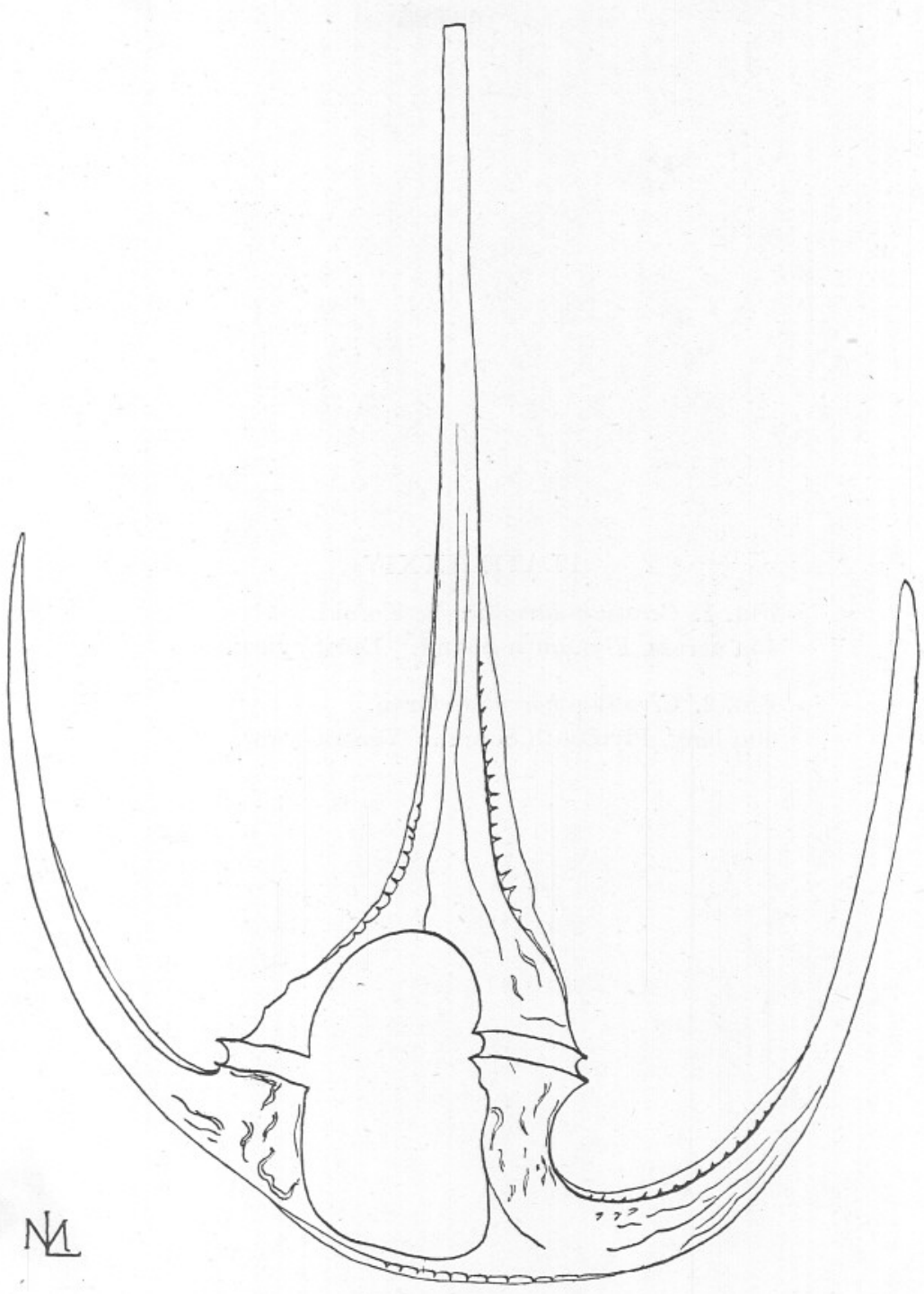




\section{PLATE XXXIV}

FIg. 1. Ceratium lamellicorne Kofoid.

$45 \mu$ across, Plymouth Sound. Dorsal view.

FIG. 2. Ceratium horridum Gran.

$60 \mu$ long, Plymouth Sound. Ventral view. 
[ 241 ]

PLATE XXXIV

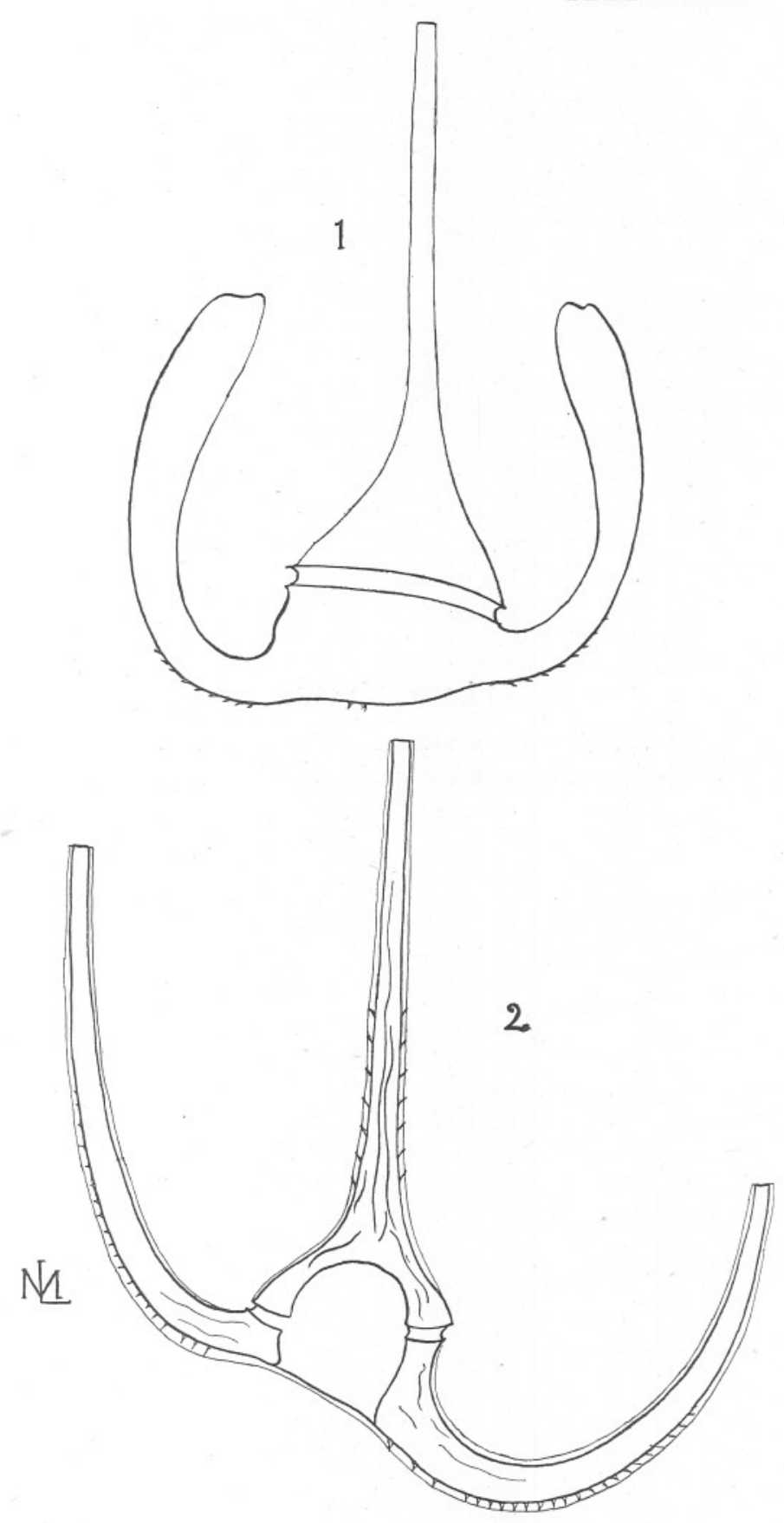

R 


\section{PLATE XXXV}

FIG. 1. Ceratium macroceros (Ehrenberg).

$45 \mu$ broad, P[ymouth Sound. Ventral view. 
[ 243 ]

PLATE XXXV

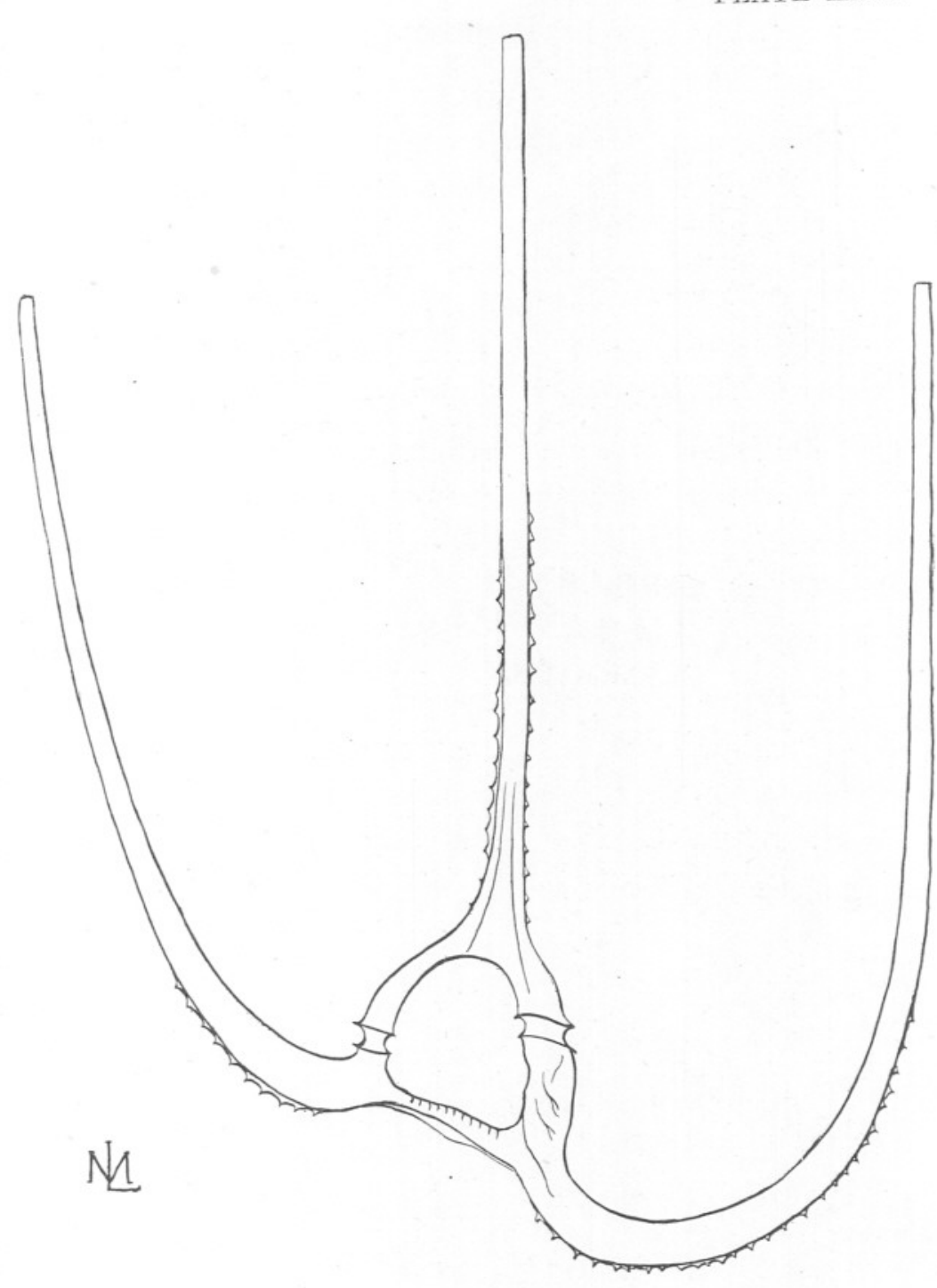




\section{INDEX}

Numerals in ordinary type refer to the description of terms, species, or text figures.

Adiniferidea, 2, 10, 12

Amoebophrya, 8, 9, 60

Amphiceratium, 142, 146

Amphidinium, 6, 7, 8, 10, 17, 21, 34, 76

asymmetricum var. britannica, 27

bipes, $22,24,29$

britannicum, 22, 23, 27

britannicum var. compacta, 27

crassum, $22,31,32$

discoidalis, $22,24,30$

eludens, 22,32

emarginatum, 22, 24, 30

extensum, $22,24,30$

flexum, 22, 27, 28

Herdmanni, 22, 23

Klebsii, 5, 22, 23, 26

Kofoidi, 22, 33, 76

Kofoidi var. petasatum, 21, 76

latum, 22, 26

longum, 22, 24, 32

manannini, 22, 24, 34,

operculatum, $22,23,24,26$

operculatum var. Steini, 23

ovoideum, $22,23,24$

ovum, $22,24,29$

pelagicum, 22, 32

pellucidum, 22, 24, 28

Phaeocysticola, 22, 31

rotundatum, 45

scissoides, 22,30

scissum, 22, 26, 31

semilunatum, 22, 24, 28, 33, 34

sphenoides, 22, 24, 30

Steini, 22, 23, 24

testudo, 22, 24, 29

vitreum, $22,24,34$

Amphisolenia, $7,11,84$

globifera, 84,85

inflata, 84, 85

Amylax lata, 96

Antapex, 2

Apex, 2

$\mathrm{R}^{*}$
Archaeperidinium, 105, 106, 107 monospinum, 107

Arenaciphilous, 7

Areole, 4

Athecatoidae, 10

Biceratium, 142, 143

Blastodiniidae, 11, 73

Blastodinium, 11, 74 hyalinum, 74

Blepharocysta, 11, 160 splendor maris, 159,160

Ceratium, 5, 6, 7, $8,11,142$ arcticum, 143, 157

azoricum, 143, 151

batavum, 156

bucephalum, 143, 151

bucephalum var. heterocampta, $143,151,152$

candelabrum, 142, 143, 144

candelabrum var. dilatata, 144

compressum, 143, 150, 151

eugrammum, 145

extensum, 142, 146, 147

furca, $142,145,150$

furca sub-sp. eugrammum, 145

fusus, $142,146,147$

gibberum, 143, 152, 153

gibberum f. sinistra, 143,153

heterocamptum, 152

hirundinella, 7, 142, 143, 144

horridum, 143, 155

intermedium, 155

intermedium $\mathrm{f}$. frigida, 156

lamellicorne, 143, 154

lineatum, 142, 144, 145, 150

longipes, $143,154,156,157$

longipes var. Baltica, 156

longipes var, ventricosa, 156

macroceros, 143,155

minutum, 142, 145

platycorne, $143,153,154$

reticulatum, $143,157,158$ 
Ceratium-continued

reticulatum f. contorta, 158

reticulatum f. spiralis, 158

tripos, 142, 147, 148

tripos var. Atlantica, 142, 149

tripos var. Atlantica f. neglecta, 142,150

tripos var. Baltica, 142, 148

tripos var. Baltica f. hiemale, 142, 147,149

tripos var. Baltica f. subsalsa, 142, 147,149

tripos f. lineata, 145,150

Chain formation, in Ceratium, 142, 144,147

Chlorophyll, 4

in Goniaulax, 91

Chromatophore, 4

Classification, 10

Cochlodinium, $8,10,61$

achromaticum, 61, 63

archimedes, 61,64

augustum, 65

Brandti, 61, 65

clarissimum, 63

faurei, 63

helicoides, 61,62

helix, $61,62,63$

pulchellum, 61,65

pupa, 61,63

Schuetti, 61, 62

vinctum, 61,63

Coloured water, 8

Conica, section, 106, 110, 111, 118

Coolia, 11, 138

monotis, 138, 139

Cyst formation, 6, 8

Dimorphism, 6

Diniferidea, 2, 10, 17

Dinoflagellata, definition, 12

Dinophysidae, $7,11,27,75$

Dinophysis, $7,8,11,21,79$

acuminata, $79,80,81$

acuta, 79

arctica, $76,79,81$

caudata, $79,80,82$

hastata, $79,80,83$

homunculus, 82

homunculus var. tripos, 82

lenticula, 79,81

norvegica, 79,80

norvegica var. crassior, 79

norvegica var. debilior, 80

ovum, 79,81

ovum var. baltica, 81

punctata, 79,81

rotundata, 78
Schuettii, $79,80,83$

sphenoides, 80

sphaerica, $79,80,82$

tripos, 79,82

uracantha, $76,79,83$

vertex, 81

Diplopelta, 100, 101

bomba, 45,100

Diplopeltopsis, 7, 11, 102

minor, 100,102

Diplopsalis, $7,8,9,11,99,105$

acuta, 102

caspica, 100

lenticula, 9, 99, 101, 102

lenticula $f$. minor, 102

minima, 100

pillula, 100

saecularis, 100

Diplopsalopsis, 11, 103

orbiculare, 103

Divergens, section, $10 \%, 110,127,129$

Ectoplasm, 35

Endoplasm, 35

Entzia, 11, 102 acuta, 102, 103

Epicone, 2

Epitheca, 3

Erythropsis, 8, 17, 69, 73

Euceratium, 142, 148

Euperidinium, 105

Exuviella, 6, 7, 10, 13

apora, 13,14

baltica, 13, 14, 15

bisimpressa, 14

compressa, 13

lima, 13

marina, 13

perforata, $12,13,14$

Eye, 4

Flagellum, 2, 3

Food, 4, 5

Girdle, 2

Girdle plate, 3

Glenodiniidae, 11, 84

Glenodinium, 11, 85

bipes, $84,137,138$

danicum, 85,86

foliaceum, 84, 104

gymnodinium, $85,86,87$

inflatum, 88

monensis, $85,86,87$

obliquum, $85,86,87$

ovatum, 94

trochoideum, 84, 113

Warmingii, 85, 86, 87 
Goniaulax, $6,7,8,11,91$

apiculata, 91,95

catenata, 91, 97, 98

diegensis, 91, 95

digitale, 91, 92, 93

fragilis, 91, 98, 99

Levanderi, 92

longispina, 94, 97

Mangini, 92

orientalis, $90,91,93$

polyedra, 91, 93, 97

polygramma, 91,94

scrippsae, 91, 93, 94

spinifera, 91,92

Tamarensis, 91,95

triacantha, $91,96,97$

turbynei, $91,93,94$

unicornis, 91,92

vexans, 92

Goniodoma, 11, 90

lacustris, 90

Ostenfeldii, 90, 91, 93

polyedricum, 90

Groove, longitudinal, 2

$$
, \text { transverse, } 2
$$

Gymnodiniidae, 10, 20

Gymnodinioidae, 10, 17

Gymnodinium, 5, 6, 7, 8, 9, 10, 34, 35, 69

abbreviatium, 35, 48, 49

achromaticum, 35,48

agile, $35,39,40$

arcticum, 35,46

conicum, 35,43

filum, 30, 35, 42

fulgens, $43,44,46,49,59$

fusus, 51

glandula, 35, 39, 41

gracile, 35, 46, 49, 59

gracile var. exigua, 49

grammaticum, 35, 38, 39

helix, 61,62

heterostriatum, 35, 47

hyalinum, 35,48

incertum, $35,39,41$

Lebourii, 35, 43, 44, 45

Lohmanni, 35, 50

lunula, $9,35,36,162$

marinum, 35,39

minor, 35,38

minutum, 35,45

monas, 40

opimum, 57

pellucidum, 35,46

placidum, 35, 39, 40

pseudonoctiluca, $35,43,44$

punctatum, 35, 50

pygmaeum, 35,38 pyrocyctis, 35,45

rhomboides, $5,7,35,47,48$

rubrocinctum, 35,42

rubrum, 42

simplex, 35, 37

spirale, 56

spirale var. bepo, 55

spirale var, obtusa, 57

spirale, var. pinguis, 58

splendens, 35,43

teredo, 66

tintinnicula, 35,50

triangularis, 35,50

variabile, $35,39,41$

vestificii, $30,35,50$

viridis, 43

Wilezeki, 35, 46, 49

Gyrodinium, 7, 8, 9, 10, 51, 69

bepo, 51,55

britannia, $8,51,56$

calyptoglyphe, 51, 52

capsulatum, 52

cochlea, 51, 59

concentricum, 51,60

contortum, 57

cornutum, 51, 60

crassum, 51,58

cuneatum, 51, 53, 59

falcatum, 51

fissum, 51, 53, 54

fucorum, 51,60

fusiforme, 51,60

fusus, 51

glaucum, $7,30,50,51,54,55$

grave, $51,53,59$

lachryma, 51, 53, 60

Lebourae, 51, 53

lingulifera, 51, 52

longum, 51, 61

obtusum, 51, 57

opimum, 51,57

ovatum, 51,61

pingue, 51,58

prunus, 51, 52, 53

spirale, $51,56,59$

Haplodinium, 6, 12

Hemidinium, 6, 10, 20

nasutum, 20

Heterocapsa triqueta, 109

Heteromorphic chains, 142

Holophytic nutrition, 4

Holozoic nutrition, 4

Humilia, section, 10\%, 110; 126, 12\%. 129,132

Hypocone, 2

Hypotheca, 3 
Intercalary areas, 4 , striae, 4

Kryptoperidinium, 11, 84, 104 foliaceum, $6,104,13 \%, 162$

Laevigella, 51

Leucoplast, 5

Lineadinium, 35

List, longitudinal, 5 ,, transverse, 5

Lobe, tentacular, 19

Luminescence, 8, 69, 147

Megacytic stage, 12

Melanosome, 69

Metaperidinium, 3, 6, 105, 106, 110 , 123

Micron, 2

Minuscula, 11, 84, 137 bipes, 137, 138

Nematocyst, 4, 64, 67, 71

Nematodinium, $8,11,71$ armatum, 71, 72

Neritic species, 7

Nitzschia closterium, 19, 37, 39, 162

Noctiluca, 4, 18, 68 scintillans, 69

Noctilucidae, 10, 68

Nucleus, 2

Nutrition, 4

Oceanic species, 7

Oceanica, section, $106,110,119,121$, 127

Ocellus, 69, 70, 71

Ornithocercus, 7

Orthoperidinium, 6, 104, 105, 106, $107,110,111$

Oxyrrhis, $6,10,17,18,19$ marina, 19

Oxytoxum, 8, 11, 139

Belgicae, 139, 140, 141

diploconus, 140, 141

gladiolus, 140, 141

Milneri, 140, 141

reticulatum, 140, 141, 142

scolopax, 140, 141

sphaeroideum, 140

Pachydinium, 35

Paraperidinium, section, 105, 106, $107,110,134$

Parasitic dinoflagellates, 6

Parasitised dinoflagellates, 8. 9

Pavillardia, 68
Pelagic species, 7

Pelagorhynchus, 18 marina, 18

Pellicle, 2, 17

Peridiniidae, 11, 12, 88

Peridinioidae, 11, 75

Peridiniopsis, $7,8,11,100$ asymmetrica, $8,100,101,102$

Borgei, 100

Penardii, 100

rotunda, 100,101

Peridinium, 5, 6, 7, 8, 9, 11, 84, 89, $105,106,110$

achromaticum, 106, 109, 114

acutangulum, 111

Adriaticum, 128

Anthonyi, 106, 115, 116

apiculata, 109

aspinum, 107

avellana, 106, 108

Balticum, 10\%, 136, 137

breve, 10\%, 127, 131, 132

brevipes, 107, 131, 132

bulla, 106, 120, 122

callosum, 125

catenatum, 97

cerasus, $10 \%, 130$

claudicans, 106, 121, 122, 123

conicoides, 106, 112

conicum, 106, 111, 112, 113, 121

conicum var. bilobata, 111

crassipes, 128,129

curvipes, 107, 133, 135

curtipes, $10 \%, 128$

decipiens, 107, 131, 132, 133

deficiens, 119

depressum, 8, 106, 119, 120, 127, 128

diabolus, 107, 135, 136

divaricatum, 116,118

divergens, $45,10 \%, 119,121$, 127

elongatum, 106, 116, 118

excentricum, 106, 108

exiguum, $13 \%$

Faeröense, 7, 106, 113

fimbriatum, 106, 115, 116

Finlandicum, 125

formosum, 136

globulus, 107, 129, 130

Granii, 106, 124, 125

inaequale, 101, 109

inconspicuum, 109

islandicum, 10\%, 135, 136

Kofoidi, 119

latum, 102

lenticulum, 126

Leonis, 7, 106, 112, 121, 129 
Peridinium-continued

macrospinum, 107, 136

marchicum, .109

minusculum, $13 \%$

minutum, $10 \%$

minutum var. Tahihouensis, 107

mite, 106, 124, 125

monacanthus, 10\%, 131, 133

monas, 40

monospinum, 106, 107

multipunctatum, 118

nudum, 106, 115, 116

oblongum, 106, 120, 121, 123

obtusum, 106, 121

oceanicum, 106, 120, 121, 123, 127

oceanicum var, claudicans, 123

oceanicum var. oblonga, 121

oceanicum var. typica, 121

orbiculare, 103

ovatum, 106, 110, 126, 130

ovatum var. minor, 126

pallidum, 10\%, 134, 136

parallelum, 119

pellucidum, 5, 7, 107, 134, 136

pellucidum var. acuta, 135

pellucidum var. crassa, 135

pellucidum var. spinosa, 134

Penardii, 100

pentagonum, 106, 111, 112, 113

Perrieri, 108

punctulatum, 106, 115, 122, 123, 124

pusillum, 109

pyriforme, 106, 126

quarnerense, 130

robustum, 106, 120, 122

roseum, 107, 130, 131

roseum var. aciculata, 130

saltans, 106, 112, 120

sinuosum, 112

speciosum, 127

stagnale, 123

Steinii, 97, 106, 125, 127, 132

Steinii sub. species Mediterranea, 125

Steinii sub. species Paulseni, 125

sub-curvipes, $107,133,135$

subinerme, $106,114,115,122$, 123

tabulatum, 106, 116, 118, 122

Thorianum, 106, 108

triqueta, 106, 109

trochoideum, 92, 106, 113

tuberosum, 123

typus, 113

umbonatum, 109

Vanhöffeni, 125

varicans, 10\%, 131, 132 verrucosum, 106, 120, 122

Willei, 106, 113

Yserense, 106, 115, 116, 118

Phaeocystis, 32

Phalacroma, 7, 11, 21, 75

acutum, 79

ebriolum, 76, 77

irregulare, 77,78

Kofoidi, 77

minutum, $76,7 \%, 78$

pulchellum, 77

rotundatum, 77,78

rotundatum var. laevis, 77,78

Rudgei, 76, 78

Plastid, 45

Plates, antapical, 88

, apical, 88

, girdle, 88

,, intercalary, 88

,, $\quad$ Precingular, 88

, Postcingular, 88

Podolampas, 11, 158

bipes, 159, 160

elegans, 160

palmipes, 159

Polykrikidae, 10, 67

Polykrikos, 5, 7, 10,67

Lebourae, 67, 68

Schwarzi, 5, 64, 67

Polymorphism, 6

Pore, 4

,, anterior flagellar, 2

, posterior flagellar, 3

Poroceratium, 142

Poroid, 4

Pouchetia, 8, 11, 71, 72

armata, 71

fusus, $10,70,72$

parva, 72,73

polyphemus, 72

rosea, $70,72,73$

Pouchetiidae, 11, 69

Prod, 8

Pronoctiluca, 6, 10, 17, 18 pelagica, 18, 19

Pronostilucidae, 10, 17

Properidinium Thorianum, 108 heterocapsa, 109

Prorocentridae, 10, 12, 13

Prorocentrum, 6, 7, 10, 13, 15

dentatum, 15, 16

micans, $7,15,16$

scutellum, 15, 16

Protoceratium, 7, 11, 88, 89 reticulatum, 45,89

Protodinifer, 17,18

marinum, 18

Protodiniferidae, 17 
Protodinium simplex, $37,70,73$

Protoerythropsis, 11, 73 vigilans, 73

Protoperidinium, 105

Protopsis, 11, 69, 70 nigra, 70

simplex, 70,71

Pseudophalacroma, 11, 75 nasutum, 75,76

Pusule, 5

Pyrenoid, 12

Pyriformia, section, 106, 110, 124, 126,132

Pyrophacus, 11, 138, 139

horologicum, 139

Red water, 8, 97

Reproduction, 6

Rhynchomonas marina, 18

Rhythm, in sand-loving forms, 21

Rotundinium, 21

Spirodinium, 51

concentricum, 60

crassum, 58

fissum, 43,54

fusus, 60 glaucum, 54

grave, 59

lachryma, 60

maximum, 56

nasutum, 56

Schüttii, 58

spirale, 56

spirale var. acuta, 56

varians, 58

Spore, 6

Steiniella, 91, 98

fragilis, 91, 99

Striae, 4

Sulcus, 2

Suture, 75

Tabulata, section, 106, 110, 115, 121, 122

Tentacle, 18

Theca, 2

Thecatoidae, 10, 12

Torodinium, 10, 65

teredo, 64,66

robustum, 66

Transverse lists, 4

Valve, 12 


\section{Journal of the Marine Biological Association of the United Kingdom.}

Old Series.

No. 1, August, 1887 (only a few copies left, reserved for Libraries). No. 2, August, 1888. Price $1 s$.

New Series (Royal 8vo).

Volume I., 1889-90, 472 pp., 28 plates.

Volume II., I891-2, 410 pp., 14 plates.

Volume III., 1893-4, xxxviii. and 458 pp., 5 plates and 25 woodeuts.

Volume IV., 1895-7, iv. and $425 \mathrm{pp}$.

Volume V., 1897-9, 550 pp. and 16 plates. Volume VI., 1899-1903, 676 pp., 3 charts and 7 plates.

Volume VII., 1904-6, 508 pp., 1 chart and 12 plates.

Volume VIII., 1907-10, 519 pp. and 24 plates.

Volume IX., 1910-13, 620 pp. and 7 plates.

Volume X., 1913-15, 676 pp. and 8 plates.

Volume XI., 1916-18, 534 pp. and 13 plates.

Volume XII., 1919-22, 854 pp., and 29 plates.

Volume XIII., 1923-25, 1021 pp., and 54 plates.

Separate numbers (generally 4 to one volume), in wrappers, from $1 s$. to $10 \mathrm{~s}$. each, according to size.

\section{PLYMOUTH AQUARIUM GUIDE BOOK}

BY

\section{E. W. SEXTON}

WITH ILLUSTRATIONS BY

L. R. BRIGHTWELL

AN ACCOUNT IN POPULAR LANGJAGE OF FISHES

AND OTHER ANimals LIVING IN THE SEA

165 pages. Price 1s. Post-free, 1s. $3 d$.

ALL PUBLICATIONS MAY BE OBTAINED FROM THE DIRECTOR, MARINE BIOLOGICAI. LABORATORY, CITADEL HILL, PLYMOUTH.

London Agents: Messrs. Dulau \& Co., Lrd., 31-46 Margaret St., Cavendish Sq., W. 1. 